2. To: (Receiving Organization)

Distribution

5. Proj./Prog./Dept./Div.:

$W-441 / 5 N F$

8. Originator Remarks:
3. From: (originating Organization) Process Engineering

6. Design Authority/ Design Agent/Cog.

J.j. Irwin $/ 4034$
4. Related EDT No,:

N/A

7. Purchase Order No.:

$$
N / A
$$

9. Equip./Component No.:

$$
\text { N/A }
$$

10. Systern/Bldg./Facility:

\section{Cold Vacuum Drying Facility}

Approval and Release

11. Receiver Remarks: 11A. Design Baseline Document? [X] Yes [] No

12. Major Assm. Dwg. No.:
$N / A$

13. Permit/Permit Application No.: $N / A$

14. Required Response Date: $05 / 02 / 97$

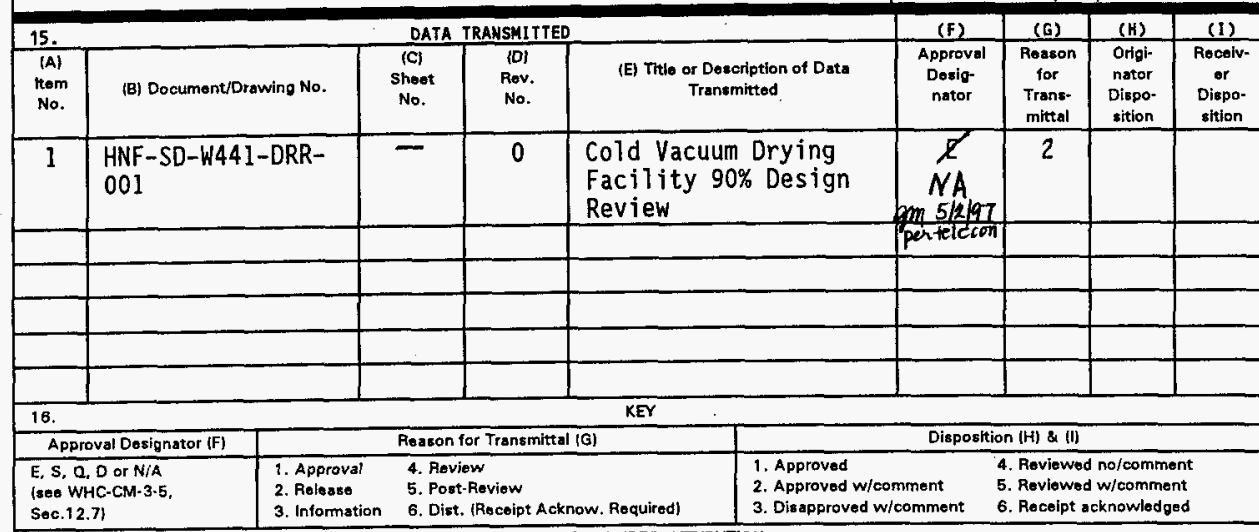

(Soo Approval Designator for required signatures)

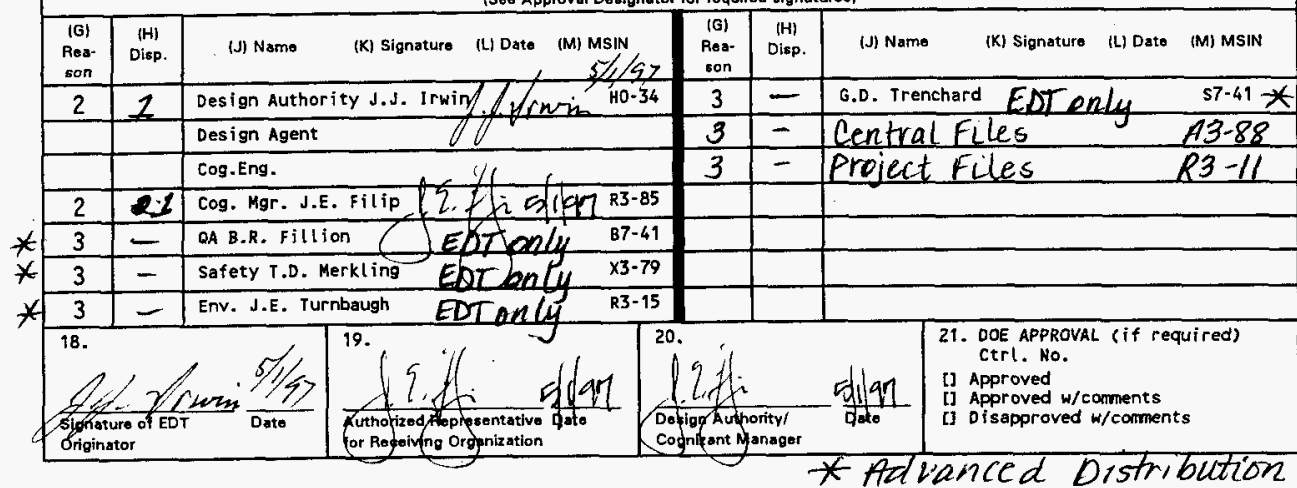




\title{
Cold Vacuum Drying Facility 90\% Design Review
}

\author{
J.E. Filip
}

Numatec Hanford Company, Richland, WA 99352

U.S. Department of Energy Contract DE-AC06-96RL13200

EDT/ECN: 618647

Org Code: 8 C800

B\&R Code: $39 E W 70400$

UC: 510

Charge Code: ${ }^{L}$ Ho34 $14 / \mathrm{gm}_{5 / 2 / 97}$

Key Words: RCR, CVDF, Comment resolution, 90\%

Abstract: This document contains signed review comment records for the CVDF 90\% design review.

TRADEMARK DISCLAIMER. Reference herein to any specific comercial product, process, or service by trade name, trademark, manufacturer, or otherwise, does not necessarily constitute or imply its endorsement, recommendation, or favoring by the United States Government or any agency thereof or its contractors or subcontractors.

Printed in the United States of America. To obtain copies of this document, contact: WHC/BCS Document Control Services, P.0. Box 1970, Mailstop H6-08, Richland WA 99352, Phone (509) 372-2420; Fax (509) 376-4989.
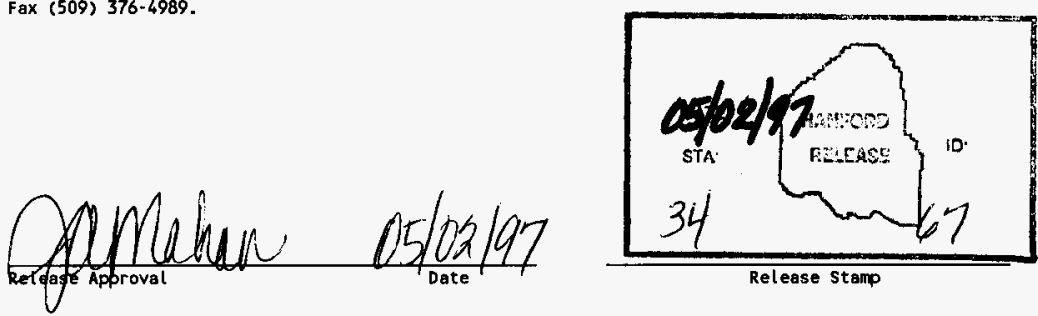

Release stamp

\section{Approved for Public Release}


Cold Vacuum Drying Facility $90 \%$ Design Review Reviewer Summary

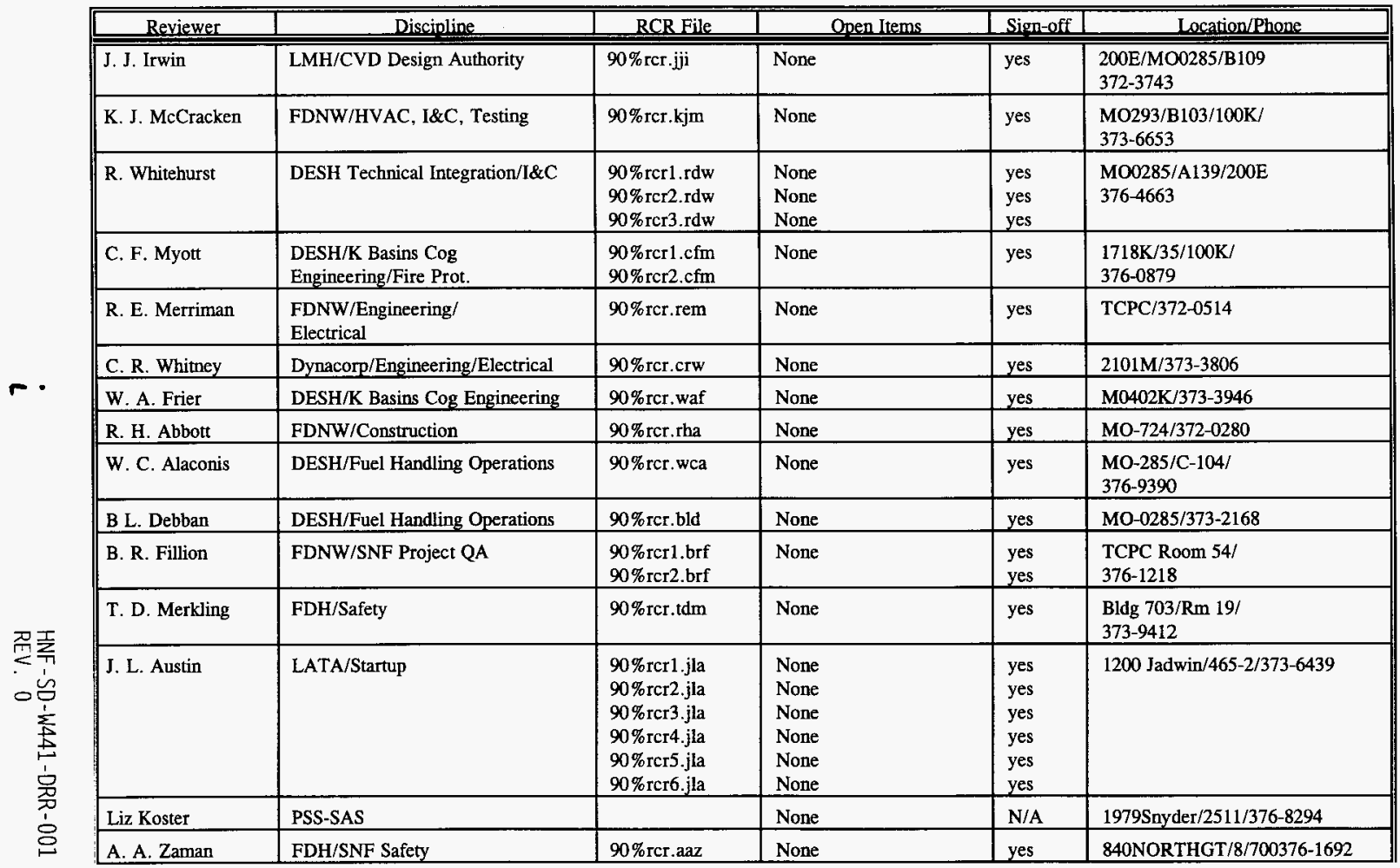




\begin{tabular}{|c|c|c|c|c|c|}
\hline SБEE-ELE T प्रర्ठTL & SशX & 3uON & "utur'IS\%06 & 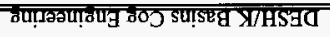 & Iग!ग V'W \\
\hline 9 9LO†-ELE / $\forall t I T Q / L L Z O-O W$ & $\mathbf{S} 2 \mathrm{~K}$ & $200 \mathrm{~N}$ & $198 \cdot 151 \% 06$ & dHNS / TQ-GOO & 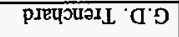 \\
\hline $0 S 0 Z-E L E /$ त्र8ILI & $\mathrm{s} \overline{\mathrm{S} K}$ & $200 \mathrm{~N}$ & 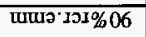 & 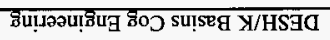 & HOKW'W'G \\
\hline $900 \varsigma-\varepsilon \angle \varepsilon /(20 \hbar O W) \times 8 T \angle T$ & $\mathbf{S O S}$ & 2UON & 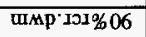 & 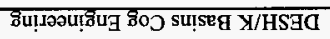 & ргојрәк $M^{\circ} \sigma$ \\
\hline$\varepsilon 8[9-9 L \varepsilon$ & S2K & 200N & md! 'गد\%06 & dnIFe'S ANS/VIVT & SMatpRW'd'I \\
\hline II9I-ZLE / 80IOW & $5 \supset K$ & गU० & १पष्त $501 \% 06$ & 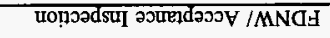 & uMOdg 'HW \\
\hline $8 Z L 9-\varepsilon \not 66$ & $\mathrm{~s} 2 \hat{\Lambda}$ & कLON & Surut $101 \% 06$ & 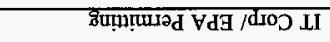 & EAI!S 'SW \\
\hline YX00I/EI/Z0t-OW & 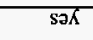 & 200N & STP.13\% $\% 06$ & 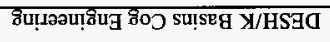 & 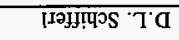 \\
\hline$\varepsilon Z 9 \varepsilon-Z L \varepsilon / G 00 Z / I 0 I \supset / A I S L Z$ & $\mathrm{~S} 2 \hat{K}$ & 2U0N & Iep $121 \% 06$ & RIPJPS dANS/roseT & אuכy ' $\forall \cdot \bar{d}$ \\
\hline 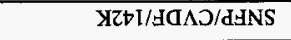 & $\operatorname{soK}$ & 2tON & 4โด' $101 \% 06$ & ริu!!ə2u! & 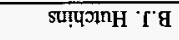 \\
\hline $9 \varepsilon \angle \varsigma-9 L \varepsilon / 900 Z / \varepsilon+0-O W$ & $\mathrm{~s} 2 \mathrm{~K}$ & $200 \mathrm{~N}$ & MIS̈.IJI\%06 & 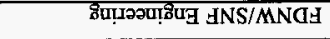 & 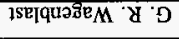 \\
\hline $6+Z \varepsilon-\varepsilon L \varepsilon / X I Z L \mathrm{I}$ & $\operatorname{sen}$ & 2นON & Yә[' $121 \% 06$ & 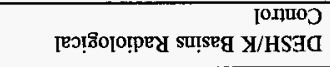 & zuny 't 1 \\
\hline $808 \mathcal{E}-\mathcal{E} L E / \mathcal{E} E /$ totoW & $5 \partial \hat{K}$ & $200 \mathrm{~N}$ & !p०.10I\%06 & K1əJeS JNS/HGH & 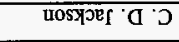 \\
\hline $8 \angle \mathcal{E}$ I-ZLE/LT/Dबר $\varepsilon 0 L$ & $S 2 X$ & गUON & S10.101\%06 & 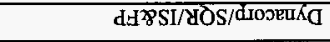 & Esturepes I I \\
\hline 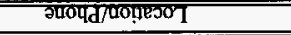 & गुण-UDis & Sपना पम्बत् & ग!़्य पर & 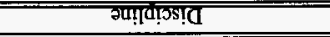 & 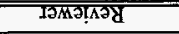 \\
\hline
\end{tabular}




\section{REVIEW COMMENT RECORD (RCR)}

\begin{tabular}{|c|l|}
\hline $\begin{array}{l}\text { 1. Date } 10 / 3 / 96 \\
\text { 3. Project No. } \\
\text { W441 CVD }\end{array}$ & 4. Page \\
\hline
\end{tabular}

5. Document Number(s)/Title(s)

Cold Vacuum Drying Facility 90\% Design Review

17. Comment Submittal Approval:

Organization Manager (Optional)

\section{Program/Project/ Building Number SNFP/CVDF/142K}

10. Agreement with indicated comment disposition(s) $1-27-9>\quad$ Reviewer/Point of Contact Date

\section{Reviewer \\ KJ McCracken}

8. Organization/Group

FDNW/Engineering
9. Location/Phone

$373-6653$ 20ansenack

11. CLOSED

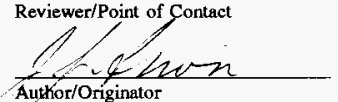

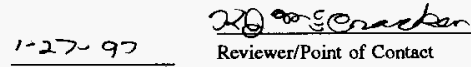

A

\begin{tabular}{|c|c|c|c|c|c|}
\hline & $\begin{array}{l}12 . \\
\text { Item }\end{array}$ & $\begin{array}{l}\text { 13. Comment(s)/Discrepancy(s) (Provide technical justification for the comment and } \\
\text { detailed recommendation of the action required to correct/ resolve the } \\
\text { discrepancy/problem indicated.) }\end{array}$ & $\begin{array}{l}14 . \\
\text { Hold } \\
\text { Point }\end{array}$ & 15. Disposition (Provide justification if NOT accepted.) & $\begin{array}{l}16 . \\
\text { Status }\end{array}$ \\
\hline \multirow{8}{*}{ 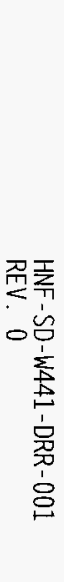 } & & GENERAL COMMENTS: & & & \\
\hline & 1 & Provide calculations for process and structure & & $\begin{array}{l}\text { Agreed. JJI: Process Cales to be included in Final Design } \\
\text { Report. }\end{array}$ & Closed \\
\hline & 2 & $\begin{array}{l}\text { Anti-C clothing removal pads should be moved to top of mezzanine } \\
\text { stairs to reduce rad zone sizes }\end{array}$ & & Agreed. & Closed \\
\hline & 3 & H-1-82113 Place details in order rather than scattered about the page & & Agreed. Will attempt to correct. & Closed \\
\hline & $\overline{4}$ & $\begin{array}{l}\text { H-1-82114 Detail } 4 \text { is missing renumber details and references on } \\
\text { called drawings }\end{array}$ & & Agreed. Will attempt to correct. & Closed \\
\hline & 5 & Provide office wall/ceiling detail perhaps on drawing H-1-82105 & & $\begin{array}{l}\text { Will evaluate. KJM: Found Wall attributes on } 82102 \text {, } \\
82103 \text {, and } 82114 \text { but it is not immediately clear like other } \\
\text { walls and ceilings referenced on } 82105 \text {. }\end{array}$ & Closed \\
\hline & 6 & $\begin{array}{l}\text { H-1- } 82113 \text { Provide detail for roof board insulation attachment to metal } \\
\text { deck. }\end{array}$ & & $\begin{array}{l}\text { Agreed. KJM Add detail or Spec. Change to callout roof } \\
\text { adhesive material and application thereof. Added to CM } \\
\text { action list. }\end{array}$ & Closed \\
\hline & 7 & $\begin{array}{l}\text { Provide details on pre-cast concrete wall panels, telescoping doors, and } \\
\text { light fixtures ( } 2 \text { or } 4 \text { bulb) }\end{array}$ & & $\begin{array}{l}\text { Agreed. KJM Provide cut sheets on doors, concrete wall } \\
\text { panels and light fixtures as part of Title III design efforts. }\end{array}$ & Closed \\
\hline
\end{tabular}




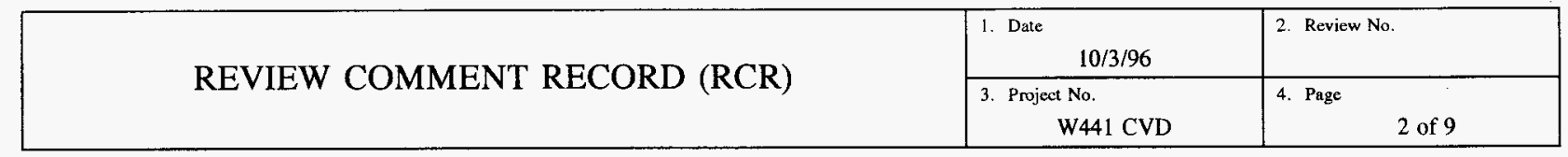

\begin{tabular}{|c|c|c|c|c|}
\hline $\begin{array}{l}12 . \\
\text { Item }\end{array}$ & $\begin{array}{l}\text { 13. Comment(s)/Discrepancy(s) (Provide technical justification for the comment and } \\
\text { detailed recommendation of the action required to correct/ resolve the } \\
\text { discrepancy/problem indicated.) }\end{array}$ & $\begin{array}{l}14 . \\
\text { Hold } \\
\text { Point }\end{array}$ & 15. Disposition (Provide justification if NOT accepted.) & $\begin{array}{l}16 . \\
\text { Status }\end{array}$ \\
\hline 8 & $\begin{array}{l}\text { H-1-82091 Cold Vacuum Drying Module should read Cold Vacuum } \\
\text { Drying Facility. }\end{array}$ & & Agreed. & Closed \\
\hline 9 & H-1-82104 Provide details for hoods and gantry hook-ups & & JJI: Process Hood added to CM Action List & Closed \\
\hline 10 & H-1-82221 Index \# on drawing is missing. & & Added. & Closed \\
\hline & HVAC DRAWING COMMENTS: & & & \\
\hline 1 & General--Provide duct hanger detail & & $\begin{array}{l}\text { Duct support details will be provided where required, i.e., } \\
\text { where special supports are needed outside scope of } \\
\text { SMACNA guidelines. Otherwise, requirements for } \\
\text { ductwork supports will be covered in Specification } 15890, \\
\text { Ductwork, by referencing to SMACNA Seismic Restraint } \\
\text { Manual with the appropriate Seismic Hazard Level (SHL) } \\
\text { indicated for the CVDF ductwork. A calculation has been } \\
\text { done using UBC and Hanford requirements to determine } \\
\text { the SHL, which is a level B. (Calc. will be included with } \\
\text { final design package). }\end{array}$ & Closed \\
\hline 2 & $\begin{array}{l}\text { H-1-82192 Replace pneumatic dampers on local exhaust hoods with } \\
\text { manual dampers unless the pneumatic dampers are normally closed } \\
\text { under power loss to provide isolation and open only to a manually } \\
\text { adjustable stop. If this is so, provide detail of typical pneumatic } \\
\text { damper used for this application. }\end{array}$ & & $\begin{array}{l}\text { Balancing dampers will be incorporated into the local } \\
\text { exhaust hood duct system. The final system configuration } \\
\text { had not been worked out before the } 90 \% \text { design package } \\
\text { was submitted and the balancing dampers were not shown. } \\
\text { The final system configuration, with manual balancing } \\
\text { dampers incorporated, will be included with the package. } \\
\text { The pneumatic dampers are provided for local isolation } \\
\text { when the exhaust system is not operating. Dampers fail } \\
\text { closed. Reference Specification } 15980 \text {, Sequence of } \\
\text { Operations - Process Bays Local Exhaust System, sections } \\
\text { 3.1.3.3 and 3.2.2. Description of dampers are included in } \\
\text { specifications. }\end{array}$ & Closed \\
\hline
\end{tabular}




\section{REVIEW COMMENT RECORD (RCR)}

\begin{tabular}{|c|l|}
\hline $\begin{array}{l}\text { 1. Date } \\
10 / 3 / 96\end{array}$ & 2. Review No. \\
\hline $\begin{array}{c}\text { 3. Project No. } \\
\text { W441 CVD }\end{array}$ & 4. Page \\
\hline
\end{tabular}

\begin{tabular}{|c|c|c|c|c|}
\hline $\begin{array}{l}12 . \\
\text { Item }\end{array}$ & $\begin{array}{l}\text { 13. Comment(s)/Discrepancy(s) (Provide techrical justification for the comment and } \\
\text { detailed recommendation of the action required to correct/ resolve the } \\
\text { discrepancy/problem indicated.) }\end{array}$ & $\begin{array}{l}14 . \\
\text { Hold } \\
\text { Point }\end{array}$ & 15. Disposition (Provide justification if NOT accepted.) & $\begin{array}{l}16 . \\
\text { Status }\end{array}$ \\
\hline 3 & $\begin{array}{l}\text { H-1-82193 Refer to HVAC Dwg. Cmt \#1 } 2 \text { for dampers HVAC-DMP- } \\
8035 \text { and }-8017 \text {. }\end{array}$ & & $\begin{array}{l}\text { These dampers are also for local isolation in the event the } \\
\text { systems associated with the respective dampers shut down. } \\
\text { JJI: methodology for balancing HVAC system added to CM } \\
\text { Action List }\end{array}$ & Closed \\
\hline 4 & $\begin{array}{l}\text { H-1-82194 Resize } 3 \times 3 \text { HEPA bank to } 3 \times 2 \text {. This is larger than the } \\
60 \% \text { design review with less flow. }\end{array}$ & & Agreed. & Closed \\
\hline 5 & $\begin{array}{l}\text { H-1-82194 Verify w/ Flanders that E-6 filters can take the "over } \\
\text { recommended flow" for the } 4 \times 3 \text { and the new resize of the } 3 \times 2 \\
\text { HEPA banks. }\end{array}$ & & $\begin{array}{l}\text { According to the Flanders catalog and conversations with } \\
\text { Flanders technical personnel, operating filters at flows in } \\
\text { excess of nominal rated capacity has little effect on } \\
\text { efficiency. The major effect of running the filters above } \\
\text { nominal capacity is an increase in the pressure drop across } \\
\text { the filter. Flanders does advise using caution when sizing } \\
\text { HEPA's for greater than nominal flows when hostile } \\
\text { environmental factors are present, such as high humidity } \\
\text { conditions where filter plugging can become a problem. } \\
\text { The design was already over specified by } 500 \mathrm{cfm} \text { for the } \\
12,000 \mathrm{cfm} \text { unit }\end{array}$ & Closed \\
\hline 6 & $\begin{array}{l}\text { H-1-82197 Provide detail on room (not bay) fume hood (if it is still } \\
\text { required). }\end{array}$ & & 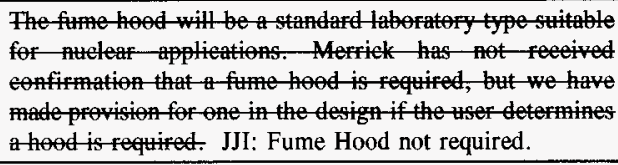 & Closed \\
\hline 7 & H-1-82201 Provide VPS chiller detail. & & Agreed. JJI: VPS chiller on H-1-82224. & Closed \\
\hline 8 & $\begin{array}{l}\text { H-1-82202 Replace transition from round exhaust duct work to square } \\
\text { duct work with round transition from } 32 \text { in. dia. to } 30 \text { in. stack dia. } \\
\text { Why transition from round to square and back to round again? }\end{array}$ & & $\begin{array}{l}\text { A rectangular duct configuration is needed at the stack inlet } \\
\text { to meet structural requirements of the stack design. } \\
\text { Maximum allowable width of duct connecting to stack is } \\
\text { approx. } 2 / 3 \text { width of stack. KJM: Design calculations will } \\
\text { be verified, added to CM Action List. }\end{array}$ & Closed \\
\hline
\end{tabular}




\section{REVIEW COMMENT RECORD (RCR)}

\begin{tabular}{|c|l|}
\hline $\begin{array}{l}\text { 1. Date } 10 / 3 / 96 \\
\text { 3. Project No. } \\
\text { W441 CVD }\end{array}$ & 4. Page \\
\hline
\end{tabular}

\begin{tabular}{|c|c|c|c|c|}
\hline $\begin{array}{l}12 . \\
\text { Item }\end{array}$ & $\begin{array}{l}\text { 13. Comment(s)/Discrepancy(s) (Provide technical justification for the comment and } \\
\text { detailed recommendation of the action required to correct/ resolve the } \\
\text { discrepancy/problem indicated.) }\end{array}$ & $\begin{array}{l}14 . \\
\text { Hold } \\
\text { Point }\end{array}$ & 15. Disposition (Provide justification if NOT accepted.) & $\begin{array}{l}16 . \\
\text { Status }\end{array}$ \\
\hline 9 & $\begin{array}{l}\text { H-1-82202 According to ASME N509/510, AG-1, and SMACNA } \\
\text { HEPA inlet transitions should not exceed } 30 \text { deg from horizontal axis } \\
\text { and outlet transitions should not exceed } 45 \text { deg from the horizontal axis } \\
\text { with a minimum of TBD distance for transition length. This will } \\
\text { provide even air distribution across filter face. }\end{array}$ & & $\begin{array}{l}\text { Space constraints prevent using transitions with optimum } \\
\text { dimensions. The resistance of the filters will assist in } \\
\text { equalizing flow across the rows and columns of filters. } \\
\text { KJM: Design calulations to be verified, added to CM } \\
\text { Action List. }\end{array}$ & Closed \\
\hline 10 & $\begin{array}{l}\text { H-i-82204 }-82205-82206 \text { Where does drain from HVAC cooling coils } \\
\text { terminate? This should terminate into holding tank. Provide detail. }\end{array}$ & & $\begin{array}{l}\text { Cooling coil drains are piped to floor drains. Floor drains } \\
\text { are piped to holding tank. Refer to Dwg. No. H-1-82223. } \\
\text { Reference arrows have been added to HVAC drawings. }\end{array}$ & Closed \\
\hline 11 & $\begin{array}{l}\text { H-1-82204 }-82205-82206 \text { Provide drains in filter sections to prevent } \\
\text { filter blow out due to possible condensation in filter housing OR } \\
\text { provide calculations that show no condensation will form in filter } \\
\text { housing. }\end{array}$ & & $\begin{array}{l}\text { The potential for condensate forming on the HEPA filters } \\
\text { is low. The process vents have potential for producing } \\
\text { some saturated air, but the ratio of the volumes of relatively } \\
\text { dry room air exhaust to process vent air is high. KJM: } \\
\text { According to the response in HVAC comment \#5 there may } \\
\text { be a reason to provide the calc for the high humidity } \\
\text { situation. Calculation to be verified in Final Design } \\
\text { Report, added to CM Action List. }\end{array}$ & Closed \\
\hline 12 & $\begin{array}{l}\mathrm{H}-1-82204-82205-82206 \text { Provide drain seal pot detail to prevent } \\
\text { possible filter bypass (refer to HVAC Dwg Cmt } \# 10 \text { ). Provide } \\
\text { calculations that show seal pots will perform adequately under expected } \\
\text { filter design conditions. }\end{array}$ & & $\begin{array}{l}\text { Drains are not required for HEPA filter sections, see } \\
\text { response comment } 11 \text {. }\end{array}$ & Closed \\
\hline 13 & $\begin{array}{l}\text { H-1-82204 -82206 Provide detail on HEPA sections, bank isolation } \\
\text { dampers, and HEPA filter test sections. Are they Flanders type which } \\
\text { provide aerosol injection port and } 100 \% \text { pre-filter test port (test section } \\
\# 1 \text { ); post filter test port/aerosol injection port and } 100 \% \text { pre-filter test } \\
\text { port (test section } \# 2 \text { ); and post filter test port (test section \#3)? If NOT } \\
\text { Flanders type provide exhaustive calculations that determine that design } \\
\text { best challenges the filters. }\end{array}$ & & $\begin{array}{l}\text { Design basis for HEPA filters is Flanders as indicated on } \\
\text { HVAC Equipment Schedule, Dwg. No. H-1-82209-1. } \\
\text { Specific descriptions of the HEPA housing, test sections, } \\
\text { filters, dampers, etc., are included in Specification 15856- } \\
\text { HEPA Filter Housing. }\end{array}$ & Closed \\
\hline
\end{tabular}




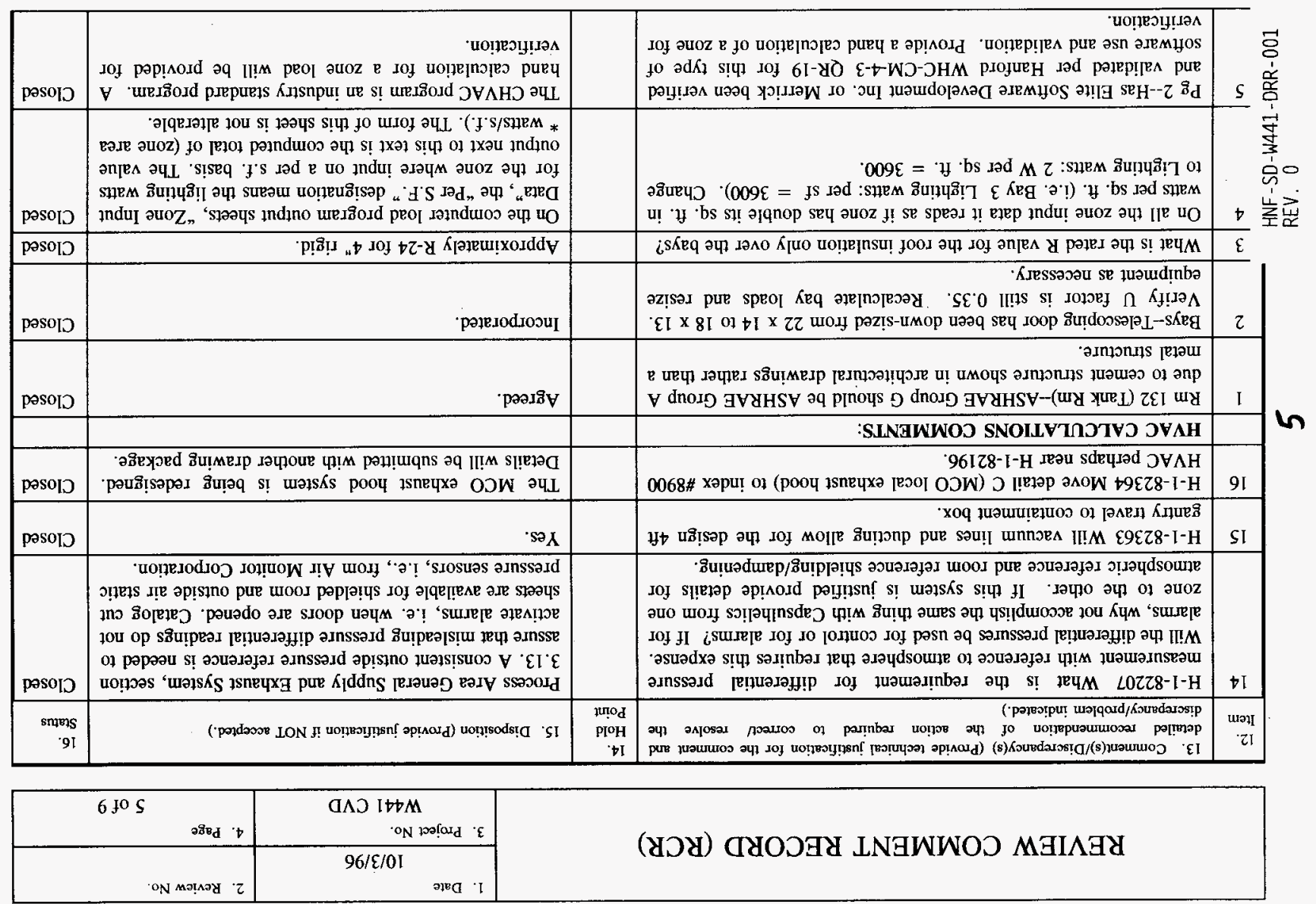




\section{REVIEW COMMENT RECORD (RCR)}

\begin{tabular}{|c|l|}
\hline $\begin{array}{l}\text { 1. Date } 10 / 3 / 96 \\
\text { 3. Project No. } \\
\text { W441 CVD }\end{array}$ & 2. Review No. \\
\hline
\end{tabular}

\begin{tabular}{|c|c|c|c|c|}
\hline $\begin{array}{l}12 . \\
\text { Item }\end{array}$ & $\begin{array}{l}\text { 13. Comment(s)/Discrepancy(s) (Provide technical justification for the comment and } \\
\text { detailed recommendation of the action required to correct/ resolve the } \\
\text { discrepancy/problem indicated.) }\end{array}$ & $\begin{array}{l}14 . \\
\text { Hold } \\
\text { Point }\end{array}$ & 15. Disposition (Provide justification if NOT accepted.) & $\begin{array}{l}16 . \\
\text { Status }\end{array}$ \\
\hline 6 & $\begin{array}{l}\text { General design parameters--provide assumptions or details of } 1 \text { Btu- } \\
\mathrm{hr} / \mathrm{ft}^{2}-\mathrm{F} \text { for cask heat gain. Is } 149 \mathrm{ft}^{2} \text { is outside of cask surface area? }\end{array}$ & & $\begin{array}{l}\text { Assumptions will be provided. Outside surface area of cask } \\
\text { is } 149 \text { s.f. }\end{array}$ & Closed \\
\hline 7 & $\begin{array}{l}\text { Pg } 31-- \text { Provide reasons for not including special allowance factor of } \\
1.08 \%-1.30 \% \text { for lighting }(1.2 \% \text { if } 110 \mathrm{VAC}) \text {. }\end{array}$ & & Included in 2 watts/s.f. lighting load. & Closed \\
\hline 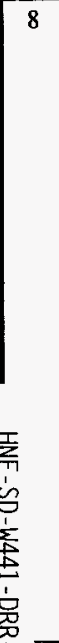 & $\begin{array}{l}\text { Load calcs, pg } 32 \text { ex. } \\
\text { A. How is Latent heat gain for infiltration determined in this program? } \\
\text { What is the humidity ration (if used)? } \\
\text { B. How is heating multiplier determine for winter infiltration and for } \\
\text { exposed concrete? }\end{array}$ & & $\begin{array}{l}\text { A. Latent gain due to infiltration: } \\
\mathrm{ql}=0.68 \text { btuh/(cfm-grains) * cfm * (inside-outside humid. } \\
\text { ratio diff. at peak, grains) * Alt. factor } \\
\text { B. Htg. Mult. for winter infil: } \\
\text { Htg. Mult. = } 1.08 \text { btuh/(cfm-F) * Alt. Factor * (Ti-To) F } \\
\text { Heat load = Htg. Mult. * cfm } \\
\text { Htg. Mult. for slab edge: } \\
\text { Htg. Mult. = edge heat loss coef.(btuh/(F-ft)) * (Ti-To) F } \\
\text { Heat load = Htg. Mult. * exposed length(ft) } \\
\text { C. There is no CLF for infiltration. CLF's apply to } \\
\text { sensible gains from people and equipment. However, } \\
\text { the CHVAC program does group the value of the } \\
\text { equation, Delta T * AF * } 1.10 " \text {, under the “-CLF-" } \\
\text { column in their "Detailed Project Zone Load } \\
\text { Calculation" output sheets, for lack of a better column } \\
\text { heading. Verify in Hand calcs }\end{array}$ & Closed \\
\hline
\end{tabular}




\begin{tabular}{|l|l|l|}
\hline \multirow{2}{*}{ REVIEW COMMENT RECORD (RCR) } & $\begin{array}{l}\text { 1. Date } 10 / 3 / 96 \\
\text { 2. Review No. }\end{array}$ & \\
\cline { 2 - 4 } & $\begin{array}{r}\text { 3. Project No. } \\
\text { W441 CVD }\end{array}$ & $\begin{array}{l}\text { 4. Page } \\
7 \text { of } 9\end{array}$ \\
\hline
\end{tabular}

\begin{tabular}{|c|c|c|c|c|}
\hline $\begin{array}{l}12 . \\
\text { Item }\end{array}$ & $\begin{array}{l}\text { 13. Comment(s)/Discrepancy(s) (Provide technical justification for the comment and } \\
\text { detailed recommendation of the action required to correct/ resolve the } \\
\text { diserepancy/problem indicated.) }\end{array}$ & $\begin{array}{l}14 . \\
\text { Hold } \\
\text { Point }\end{array}$ & 15. Disposition (Provide justification if NOT accepted.) & $\begin{array}{l}16 . \\
\text { Status }\end{array}$ \\
\hline 9 & 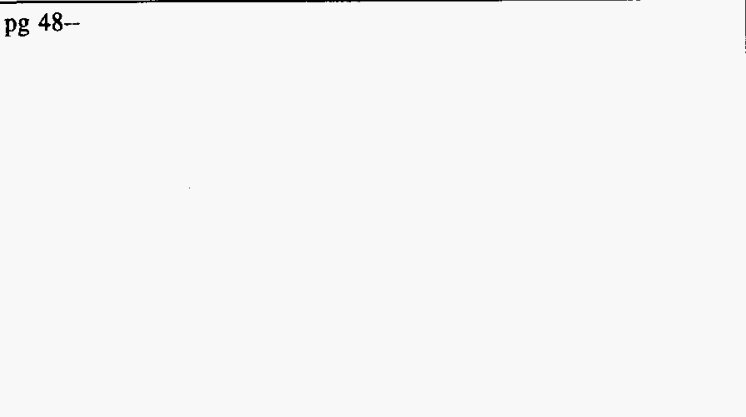 & & $\begin{array}{l}\text { Note: The following is for informational purposes. For our } \\
\text { design purposes, we used the computer program to } \\
\text { calculate the loads for the zones using the "Zone } \\
\text { Summary" computer outputs, and then used that } \\
\text { information to determine equipment sizing. The delta T's } \\
\text { and load values shown on "Total Load Summary" computer } \\
\text { outputs may not exactly match what we calculated in our } \\
\text { "Load Summary" and "Psychrometric" reports. The "Total } \\
\text { Load Summary" outputs where used for internal checking } \\
\text { purposes. These "Total Load Summary" output sheets will } \\
\text { not be included with the final package, as it can be difficult } \\
\text { without a manual to interpret how some values are } \\
\text { calculated in the program. }\end{array}$ & Open \\
\hline & $\begin{array}{l}\text { A. Explain why } 64,335 \text { Btu-hr was used as sensible load rather than } \\
64,698 \text { Btu-hr and where does the } 64,335 \text { Btu-hr show up in the } \\
\text { calcs? }\end{array}$ & & $\begin{array}{l}\text { A. The computer program uses the system peak time } \\
\text { instead of the zone peak time to calculate the zone } \\
\text { sensible load for the system. On our "Load Summary" } \\
\text { and "Psychrometric" sheets we elected to use the zone } \\
\text { peak loads, a more conservative value, for sizing } \\
\text { equipment. }\end{array}$ & $C \angle \operatorname{CoS} E D$ \\
\hline$\sum_{+}^{\frac{1}{S}}$ & $\begin{array}{l}\text { B. Explain the } 13 \text { degree delta } T \text { on heating and } 15 \text { degree delta } T \text { on } \\
\text { cooling. Are these across the coils? If so why } 15 \text { deg. for } \\
\text { cooling rather than the } 10-11 \text { deg. stated on psychometrics pg. } 1 \text {. }\end{array}$ & & $\begin{array}{l}\text { B. For heating, the } 13 \text { degree delta } \mathrm{T}=1 \text { leaving heating } \\
\text { coil temp - design space temp, } 85-72=13 \mathrm{~F} \text {. } \\
\text { For cooling, the } 15 \text { degree delta } \mathrm{T}=\text { design space } \\
\text { temp - leaving coil temp, } 75-60=15 \mathrm{~F} \text {. }\end{array}$ & \\
\hline 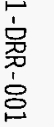 & $\begin{array}{l}\text { Explai } \\
\text { n } \\
\text { where } \\
90,07\end{array}$ & & $\begin{array}{l}\text { C. The } 90,070 \text { btuh comes from the total of zone sensible } \\
\text { peak load (computed at zone sensible peak time, not } \\
\text { system sensible peak time) plus the draw-thru fan } \\
\text { sensible gain, } 64,335 \text { btuh }+25,735 \text { btuh }=90,070\end{array}$ & \\
\hline
\end{tabular}




\section{REVIEW COMMENT RECORD (RCR)}

\begin{tabular}{|c|l|}
\hline $\begin{array}{l}\text { 1. Date } \\
10 / 3 / 96\end{array}$ & 2. Review No. \\
\hline $\begin{array}{c}\text { 3. Project No. } \\
\text { W441 CVD }\end{array}$ & 4. Page 8 of 9 \\
\hline
\end{tabular}

\begin{tabular}{|c|c|c|c|c|}
\hline $\begin{array}{l}12 . \\
\text { Item }\end{array}$ & $\begin{array}{l}\text { 13. Comment(s)/Discrepancy(s) (Provide technical justification for the comment and } \\
\text { detailed recommendation of the action required to correct/ resolve the } \\
\text { discrepancy/problem indicated.) }\end{array}$ & $\begin{array}{l}14 . \\
\text { Hold } \\
\text { Point }\end{array}$ & 15. Disposition (Provide justification if NOT accepted.) & $\begin{array}{l}16 . \\
\text { Status }\end{array}$ \\
\hline 10 & $\begin{array}{l}\text { Slot Hood Sizing Calcs-- } \\
\text { A. Where is slot sizing calc } 2288 \text { HV1B (pg 6) } \\
\text { B. Identify } 2000 \mathrm{fpm} \text { origin in slot size calc. (Pg 3) Is this from table } \\
3.2 \text { ? }\end{array}$ & & $\begin{array}{l}\text { A. Mistake in reference. This calculation appears on } \\
\text { page } 3 \text {, Calc. No. MER-2288-HV-19. } \\
\text { B. From Industrial Ventilation page } 10-93 \text {, para. } 10.70 .1 \text {, } \\
\text { item } 4 \text {, and page } 10-102 \text {, figure A. The velocity value was } \\
\text { selected to provide relatively even flow distribution across } \\
\text { slot face. } \\
\text { Slot hood is being redesigned. }\end{array}$ & Closed \\
\hline \multirow[t]{2}{*}{11} & $\begin{array}{l}\text { Chilled water pump pressure calcs pg } 4 \text { bottom } 10.0+10.0+1.2= \\
21.2 \text { not } 22.2 \text { however the total on the following page is correct. }\end{array}$ & & Incorporated. & Closed \\
\hline & PROCESS DRAWING COMMENTS: & & & \\
\hline 1 & H-1-82101 or -82200 Identify air gompressor location. & & Done. & Closed \\
\hline 2 & $\begin{array}{l}\text { H-1-82160 Define continuation line (vertical squiggle line) with an ' } u \text { ' } \\
\text { before it for all drawings in set. }\end{array}$ & & Will do. $\mathrm{u}=\mathrm{IA}$ Instrument Air & Closed \\
\hline 3 & $\begin{array}{l}\text { H-1-82162 During Nitrogen recycle, the flow is shown through the } \\
\text { condenser tank. Would this cause entrainment of water back into the } \\
\text { MCO? }\end{array}$ & & $\begin{array}{l}\text { Flow is through tank to provide knock-out pot for any } \\
\text { condensed } \mathrm{H}_{2} \mathrm{O} \text {. At only } 20 \mathrm{scfm} \text {, re-entrainment not } \\
\text { likely. }\end{array}$ & Closed \\
\hline 4 & $\begin{array}{l}\text { H-1-82162 A preferred method of evacuation and recycle is to not suck } \\
\text { or blow on the condensate tank directly in line. If a drain down line } \\
\text { was perhaps } 1 \text { in. the smaller diameter would decrease the water } \\
\text { transport rates out of the condenser to the vacuum pump. Blazers has } \\
\text { condenser with a drain down tank as one integral unit. }\end{array}$ & & $\begin{array}{l}\text { Condensate tank acts as a knock-out pot with large cross- } \\
\text { section of very low velocity unable to retain } \mathrm{H}_{2} \mathrm{O} \text { drops. } \\
\text { Blazers Design researched and salesperson (Rick Van } \\
\text { Vorous) discouraged use because too expensive, overly } \\
\text { complicated, and not appropriate design for our use. }\end{array}$ & Closed \\
\hline 5 & $\begin{array}{l}\text { H-1-82162 and }-82351 \text { Verify process piping labels. PV-102-SS-1" and } \\
\text { PV-103-SS-1", respectively, are the same pipe. }\end{array}$ & & JJI: Line number changes before and after the condenser. & Closed \\
\hline 6 & $\begin{array}{l}\mathrm{H}-1-82351 \text { Provide dual range pressure transducer }(0.1 \text { to } 10 \text { torr and } \\
10 \text { to } 1000 \text { torr) at pump inlet. }\end{array}$ & & Done. & Closed \\
\hline
\end{tabular}




\begin{tabular}{|c|c|c|c|c|}
\hline pesolo & 乙 & & 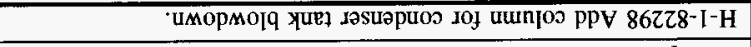 & $\varepsilon$ \\
\hline pesolp & HIOd & & 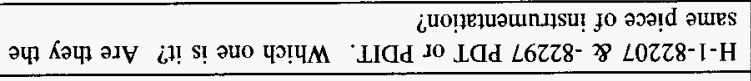 & $\tau$ \\
\hline pesolp & Kןuo sume pur su!̣ol!uoW & & 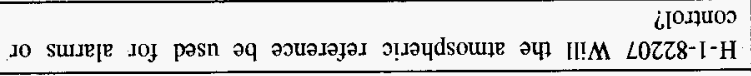 & $\mathrm{I}$ \\
\hline & & & :S.LNGWWOD $28 \mathrm{I}$ & \\
\hline pasolo & 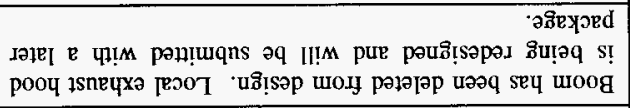 & & 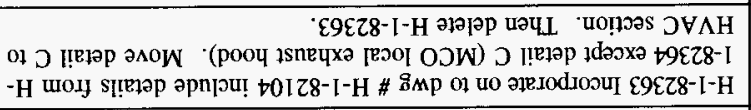 & 6 \\
\hline pesolp & 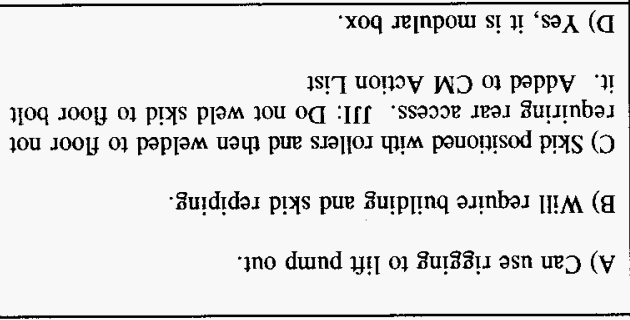 & & 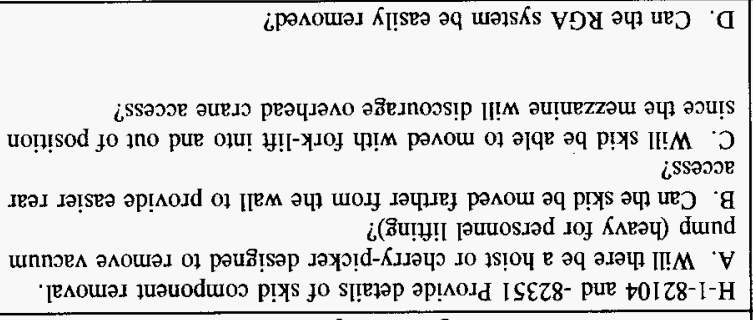 & 8 \\
\hline pasota & วu०d & & 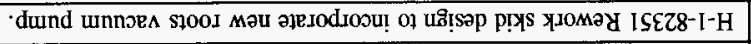 & L \\
\hline $\begin{array}{r}\text { stress } \\
91\end{array}$ & 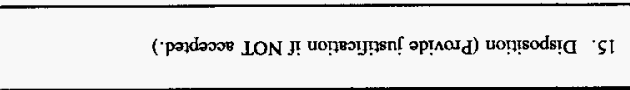 & $\begin{array}{c}\text { juipd } \\
\text { ploH } \\
\text { tI }\end{array}$ & 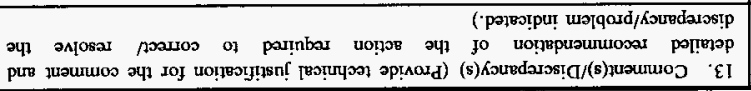 & $\begin{array}{r}\text { uюा| } \\
\text { 'ZI }\end{array}$ \\
\hline
\end{tabular}

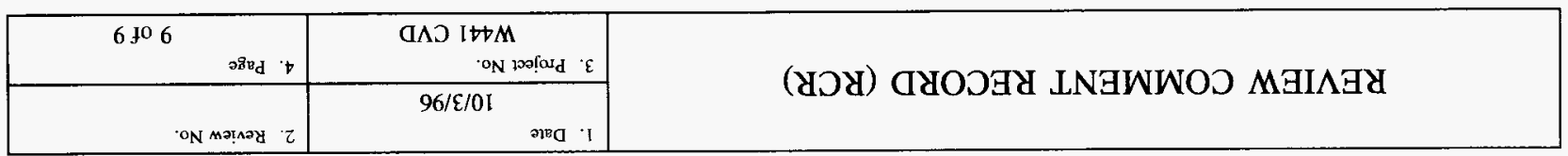




\begin{tabular}{|c|c|c|}
\hline \multirow{2}{*}{ REVIEW COMMENT RECORD (RCR) } & $\begin{array}{l}\text { 1. Date } \\
10 / 3 / 96\end{array}$ & $\begin{array}{l}\text { 2. Review No. } \\
\text { Whitehurst }\end{array}$ \\
\hline & $\begin{array}{l}\text { 3. Project No. } \\
\qquad \mathrm{W}-441-\mathrm{Cl}\end{array}$ & $\begin{array}{l}\text { 4. Page } \\
1 \text { of } 6\end{array}$ \\
\hline
\end{tabular}

\begin{tabular}{|l|l|l|l|l|}
\hline 5. Document Number(s)/Tite(s) & $\begin{array}{l}\text { 6. Program/Project } \\
\text { Bujlding Number } \\
\text { CVD }\end{array}$ & 7. Reviewer & 8. Organization/Group \\
$\begin{array}{l}\text { CVD 90\% DESIGN REVIEW DCS AND } \\
\text { INSTRUMENT REVIEW }\end{array}$ & R. Whitehurst & $\begin{array}{l}\text { DESH Technical } \\
\text { Integration }\end{array}$ \\
\hline
\end{tabular}

\section{Comment Submittal Approval:}

Organization Manager (Optional)
10. Agrement with indicated comment disposition(s)
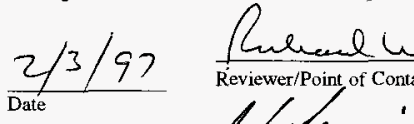

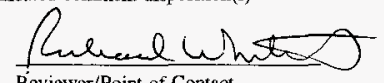

Reviewer/Point of Contact

is

11. CLOSED

guthor/Originator
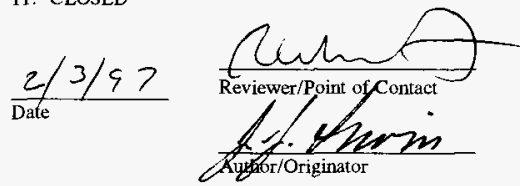

\begin{tabular}{|c|c|c|c|c|c|}
\hline & $\begin{array}{l}12 . \\
\text { Item }\end{array}$ & $\begin{array}{l}\text { 13. Comment(s)/Discrepancy(s) (Provide technical justification for the comment and } \\
\text { detailed recommendation of the action required to correct/ resolve the } \\
\text { discrepancy/problem indicated.) }\end{array}$ & $\begin{array}{l}14 . \\
\text { Hold } \\
\text { Point }\end{array}$ & 15. Disposition (Provide justification if NOT accepted.) & $\begin{array}{l}16 . \\
\text { Status }\end{array}$ \\
\hline & 1 & $\begin{array}{l}\text { H-82160: Still not shown. } 60 \% \text { \#20: Add S.P. (SetPoint) to the MISC } \\
\text { ABBREVIATIONS on H-2-826760-1. }\end{array}$ & & Will add, sorry. & accept \\
\hline 盄侌 & 2 & $\begin{array}{l}\text { H-82160: In general there are still many symbols and abbreviations that } \\
\text { don't show on this legend sheet. Every one should be shown. } \\
\text { Examples: RGA is missing, ERJ from H-1-82164, Valves and stuff on } \\
\text { top of MCC symbol on H-1-82161, "QD" for quick disconnect on H-1- } \\
82161 \text {, What are the } 2 \text { " E/T on the piping on H-1-82161, dark lines } \\
\text { with circles from FIC to PIC } 1118 \text { on H-1-82161 (this could be a DCS } \\
\text { symbol but the circles are filled in on } 82160 \text {. }\end{array}$ & & Will add, sorry. & accept \\
\hline 究 & 3 & $\begin{array}{l}\text { H-1-82165: SMP should be SM for Stack Monitoring. This was } \\
\text { provided at a meeting to Merrick/Meier on } 9 / 5 / 96 \text {. }\end{array}$ & & SMP was used to define "SAMPLE", SMP will be Changed to SM. & accept \\
\hline 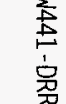 & 4 & $\begin{array}{l}60 \% \text { \#22: On H-2-826762 Sht } 1 \text { what does the dark circle mean besides } \\
\text { the "SET" which is located next to PCV } 1125 \text { or } 1124 \text { ? If this has } \\
\text { meaning add to abbreviations. }\end{array}$ & & Is the @ symbol. Changed P\&ID's to "SET AT". & accept \\
\hline$\stackrel{1}{8}$ & 5 & $\begin{array}{l}\text { H-1-82161: What is the point of showing the Special box SP/01-05 for, } \\
\text { what looks like, a flex hose going to the MCO? Other P\&ID don't } \\
\text { identify it as a special. Please remove unless there is some benefit. }\end{array}$ & & $\begin{array}{l}\text { We are fixing the specialty items listing and designation on } \\
\text { P\&ID's Intended for special equipment not carrying a tag } \\
\text { number. }\end{array}$ & accept \\
\hline
\end{tabular}




\begin{tabular}{|c|c|c|c|c|c|}
\hline \multirow{2}{*}{\multicolumn{3}{|c|}{ REVIEW COMMENT RECORD (RCR) }} & $\begin{array}{r}\text { 1. Date } \\
10 / 3 / 96 \\
\end{array}$ & \multicolumn{2}{|l|}{$\begin{array}{r}\text { 2. Review No. } \\
\text { Whitehurst } \\
\end{array}$} \\
\hline & & & $\begin{array}{l}\text { 3. Project No. } \\
\text { W-441-C1 }\end{array}$ & 4. Page & \\
\hline $\begin{array}{l}12 . \\
\text { Item }\end{array}$ & $\begin{array}{l}\text { 13. Comment(s)/Discrepancy(s) (Provide technical justification for the comment and } \\
\text { detailed recommendation of the activu required to correct/ resolve the } \\
\text { discrepancy/problem indicated.) }\end{array}$ & $\begin{array}{l}14 . \\
\text { Hold } \\
\text { Point }\end{array}$ & 15. Disposition (Provide justification if $\mathrm{N}$ & & $\begin{array}{l}16 . \\
\text { Status }\end{array}$ \\
\hline 6 & $\begin{array}{l}60 \% \text { \#32: On the symbol drawing H-2-826760 Sht. } 1 \text { the GOV symbol } \\
\text { needs to be added and the physical separation between the actuator and } \\
\text { valve needs to be very short. The actuators for motor and piston really } \\
\text { need to be removed and replaced with a whole valve which would } \\
\text { include the GOV and MOV. }\end{array}$ & & Symbol removed. & & accept \\
\hline 7 & $\begin{array}{l}\text { On H-1-82246 and } 82247 \text { and all electrical drawings, Distribution } \\
\text { Panels should be D52-XXX, Lighting panels should be LPN (normal) or } \\
\text { LPE (emergency) and Switchgear should be SWGR-XXX. Refer to } \\
\text { pages } 3 \text { through } 6 \text { of the SNF Labeling Guide for specific nomenclature } \\
\text { for electrical panels. }\end{array}$ & & $\begin{array}{l}\text { RW: Corrections will be added to : } \\
\text { ECN. This item added to CM Act }\end{array}$ & $\begin{array}{l}\text { pplicable drawings by } \\
\text { ist. }\end{array}$ & accept \\
\hline 8 & $\begin{array}{l}\text { H-1-82151 sht 1: Has incorrect references to heaters, pumps and } \\
\text { electrical panels. Make all labeling consistent with P\&ID } \\
\text { identifications. }\end{array}$ & & Drawing has been deleted. & & accept \\
\hline 9 & H-1-82152 same as number 15 . & & Drawing has been deleted. & & accept \\
\hline 10 & H1-82153 same as number 15 . & & Drawing has been deleted. & & accept \\
\hline 忿产 & $\begin{array}{l}\text { Dwg. H-1-82160 is the first sheet of the P\&IDs and there are a number } \\
\text { of "COMPONENT IDENTIFICATIONS" that are missing from what is } \\
\text { used. DI is used for Demin Water not DW, please delete IN2 as it will } \\
\text { not be used. Bottom line: make sure all component ids are identified } \\
\text { here and that they are consistent throughout the drawing set and } \\
\text { procedures. Add MCO also. }\end{array}$ & & $\begin{array}{l}\text { We will review again before final i } \\
\text { DI used for Demin Water, LW sha } \\
\text { add CA, CCS, CHW, EF, EXH, F } \\
\text { NPW, RA, SANS, SMP, RS and R } \\
\text { CM Action List. }\end{array}$ & $\begin{array}{l}\text { RW: IN2 replaced, } \\
\text { changed to PWC, } \\
\text { TPW, HVAC, IA, } \\
\text { This item added to }\end{array}$ & accept \\
\hline 窟12 & $\begin{array}{l}\text { Dwg. H-1-82160: Question, the Heating Coils "HCL" are they } \\
\text { electrical or more mechanical. A coil refers to mechanical coils. If } \\
\text { they are electrical heaters then "HTR" should be used. Maybe HCL is } \\
\text { ok to use but make sure HTR is used elsewhere. The ones used in } \\
\text { HVAC like on H1-82194 are HTRs not the other! }\end{array}$ & & We will change HCL to HTR and a & to component list. & accept \\
\hline
\end{tabular}




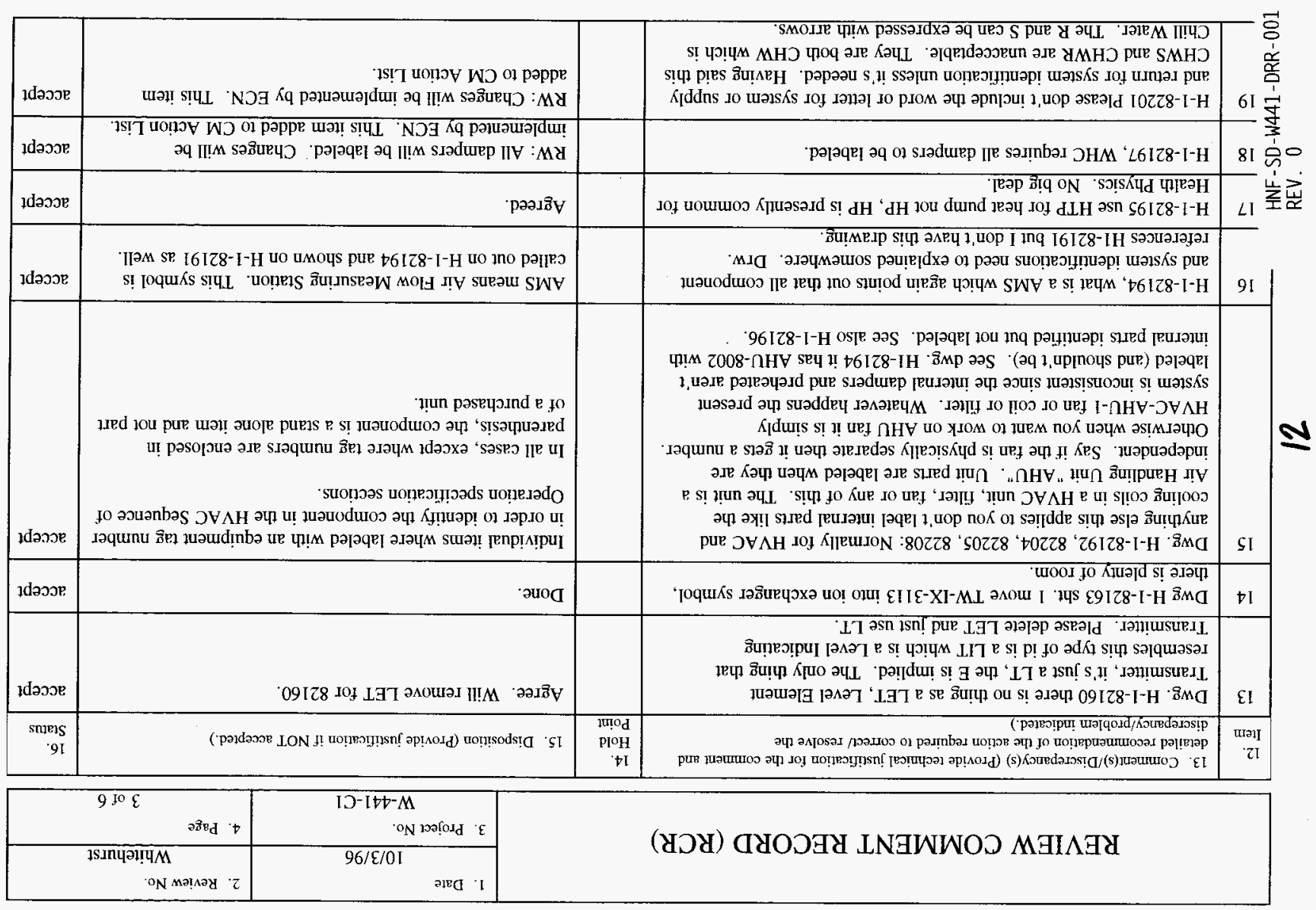




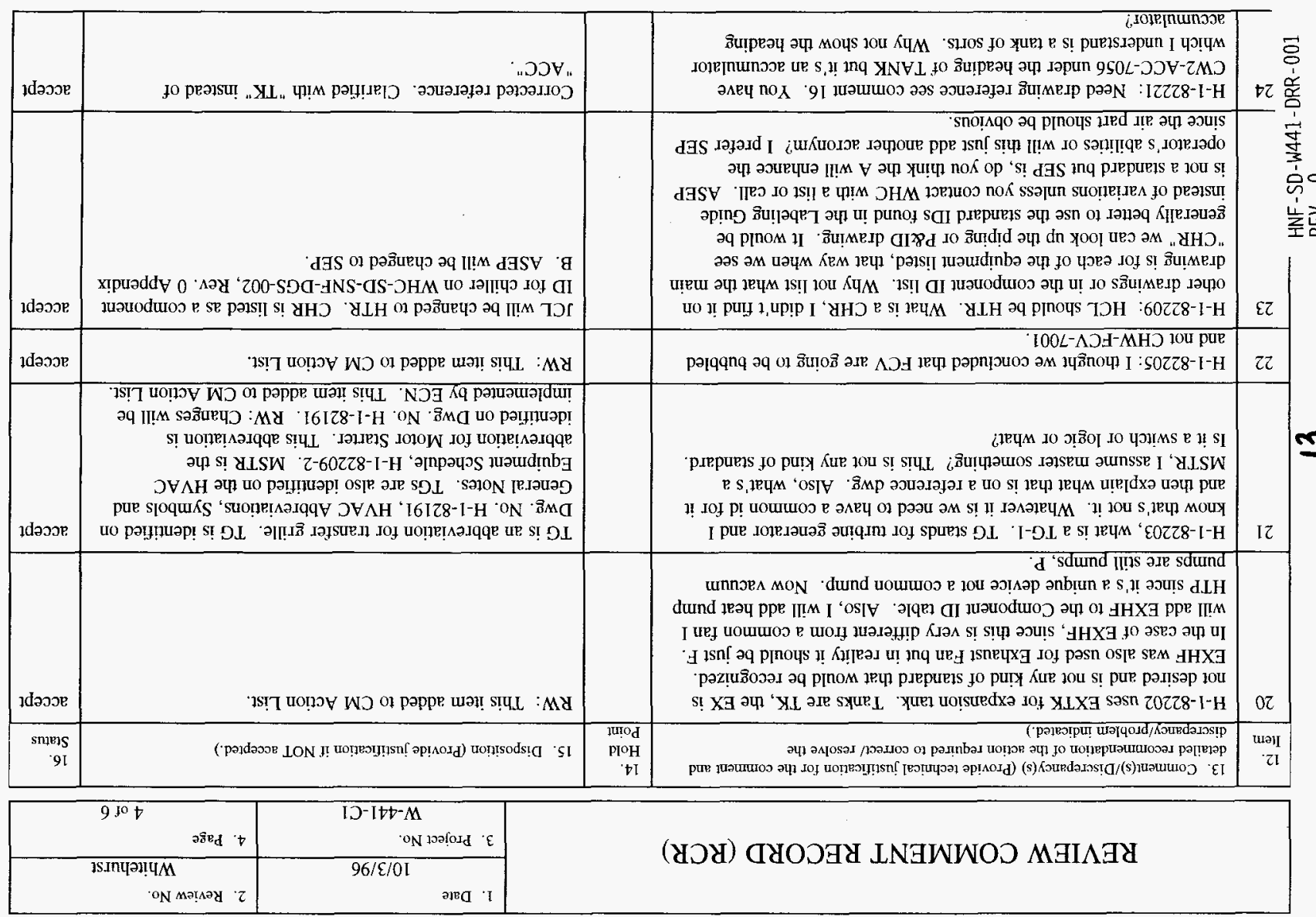




\begin{tabular}{|c|c|c|}
\hline \multirow{2}{*}{ REVIEW COMMENT RECORD (RCR) } & $10 / 3 / 96$ & $\begin{array}{l}\text { 2. Review No. } \\
\text { Whitehurst }\end{array}$ \\
\hline & $\begin{array}{l}\text { 3. Project No. } \\
\text { W-44I-Cl }\end{array}$ & $\begin{array}{l}\text { 4. Page } \\
5 \text { of } 6\end{array}$ \\
\hline
\end{tabular}

\begin{tabular}{|c|c|c|c|c|}
\hline $\begin{array}{l}12 . \\
\text { Item }\end{array}$ & $\begin{array}{l}\text { 13. Comment(s)/Discrepancy(s) (Provide technical justification for the comment and } \\
\text { detailed recommendation of the action required to correct/ resolve the } \\
\text { discrepancy/problem indicated.) }\end{array}$ & $\begin{array}{l}14 . \\
\text { Hold } \\
\text { Point }\end{array}$ & 15. Disposition (Provide justification if NOT accepted.) & $\begin{array}{l}16 . \\
\text { Status }\end{array}$ \\
\hline 25 & $\begin{array}{l}\mathrm{H}-1-82224 \text { : As previously identified CW1, CW2 and CW3 are no } \\
\text { longer going to be used. }\end{array}$ & & Corrected CW to CHW on Chilled Water. & accept \\
\hline 26 & $\begin{array}{l}\text { H-1-82243: What is the component ID for the Gastech O2 Monitors? } \\
\text { If this device is shown or referenced it needs to have this ID, } \\
\text { "O2MON". }\end{array}$ & & $\begin{array}{l}\text { Needed smaller ID, very clear as shown. RW: Changes will } \\
\text { be implemented by ECN. This item added to CM Action } \\
\text { List. }\end{array}$ & accept \\
\hline 27 & $\begin{array}{l}\text { H-1-82164: Cooling Water arrows refer to } \mathrm{H}-1-82227 \text {, this is not the } \\
\text { right one. I thought we were going to get a P\&ID that included } \mathrm{CW} \text {. } \\
\text { We now have P\&IDs for CHW, CA/LA, and the gas systerns, which are } \\
\text { very nice. The piping ID still refers to CW } 3 \text { which was changed. }\end{array}$ & & Will be corrected appropriately. & accept \\
\hline 28 & $\begin{array}{l}\text { The P\&IDs (H-1-82162-82166) still refer to piping layout drawings and } \\
\text { they should refer to the new GAS (H-1-82222 sht } 1 \text { ), CHW (H-1- } \\
82224) \text {, AIR (H-1-82222 sht 2), Drains and LW (H-1-82223). Old } \\
\text { references include H-1-82225 through } 82228 \text {. }\end{array}$ & & Last minute changes caused problems. Will be corrected. & accept \\
\hline 29 & $\begin{array}{l}\text { H-1-82228 doesn't show bay } 1 \text { at all for the different TWC and } \\
\text { VPSCHW piping, why? There is room and right now some drawings } \\
\text { refer to the pipes that aren't shown. }\end{array}$ & & $\begin{array}{l}\text { Shown in Detail 1. Added to Second Floor Plan. Note } \\
\text { piping is stacked below CHW pipe. }\end{array}$ & accept \\
\hline 30 & $\begin{array}{l}\text { H-1-82162: Reference to Process Vent zone D1 should be to Dwg H-1- } \\
82163 \text { not } 2 \text {. }\end{array}$ & & Done, thank you. & accept \\
\hline 31 & $\begin{array}{l}\text { DCS Spec: What can be done at a "VIEW" station as far as printing to } \\
\text { the MIS Printer? Will View allow this? }\end{array}$ & & $\begin{array}{l}\text { Logging and printing can be conducted at "VIEW" stations, } \\
\text { actual field control cannot be conducted at "VIEW" stations. }\end{array}$ & accept \\
\hline 32 & $\begin{array}{l}\text { DCS Spec: What can be done at a "VIEW" station as far as printing to } \\
\text { the MIS Printer? Will View allow this? }\end{array}$ & & See above. & accept \\
\hline 33 & $\begin{array}{l}\text { H-1-82161: PV-F-1111 is on the VPS line, not Process Vent. It should } \\
\text { not be named PV. }\end{array}$ & & Corrected, thank you. & accept \\
\hline 34 & $\begin{array}{l}\text { H-1-82161: The N2 and HE reference at C1 (N2-101-SS-1") go to H-I- } \\
82226 \text { which only has } 1 / 2 \text { inch lines. I think the } 1 \text { " should be a } 1 / 2 " \text {. } \\
\text { Also see comment on the use of H-1-82222 instead of } 82226 \text { for Gas } \\
\text { P\&IDs. }\end{array}$ & & $\begin{array}{l}\text { The He and } N_{2} \text { headers are supposed to be } 1 " \text { all the way to } \\
\text { the skid. The facility DWGS will be changed to reflect } \\
\text { corrections. }\end{array}$ & accept \\
\hline
\end{tabular}




\begin{tabular}{|c|c|c|c|c|}
\hline 1daวox & 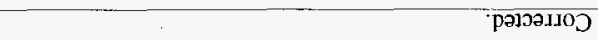 & & 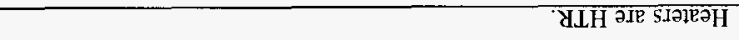 & 1 \\
\hline 1dasox. & 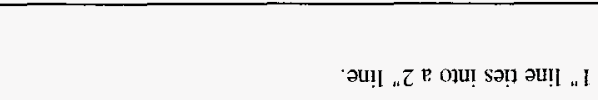 & & 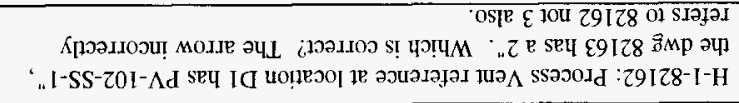 & $0 t$ \\
\hline 1อdววอย & pəIอว.110 & & 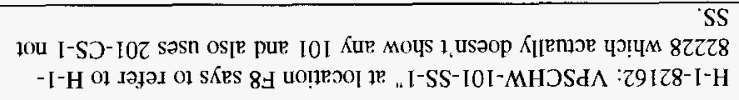 & $6 \varepsilon$ \\
\hline ๖dəวว & 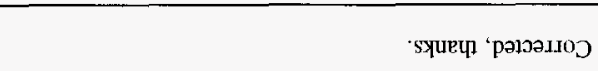 & & 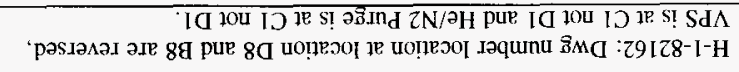 & $8 \varepsilon$ \\
\hline ๆdəววย & 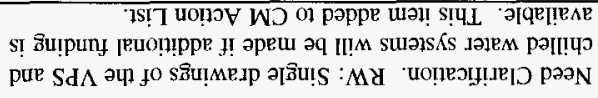 & & 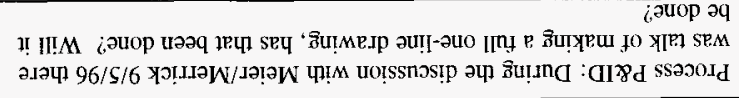 & $\angle \varepsilon$ \\
\hline ๆdววว? & 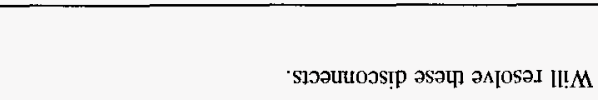 & & 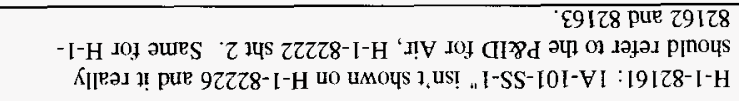 & $9 \varepsilon$ \\
\hline 1daวox & '09IZ8 ol uə1SKS S SE ppe II!M & & 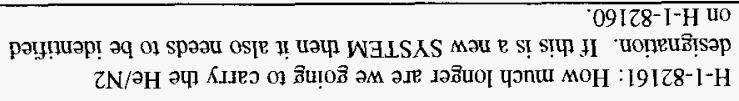 & $\mathfrak{S E}$ \\
\hline $\begin{array}{r}\text { stuens } \\
91\end{array}$ & 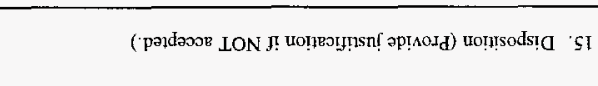 & plö & 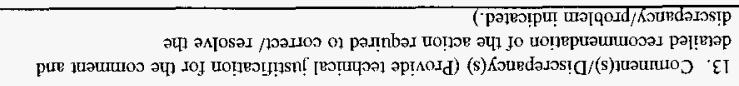 & 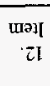 \\
\hline
\end{tabular}

\begin{tabular}{|c|c|c|}
\hline 9 J09 & 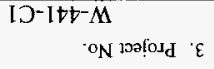 & (У)У) ЯУО \\
\hline 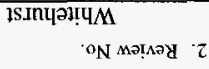 & 96/E/0I & 1018 \\
\hline
\end{tabular}




\begin{tabular}{|c|c|c|}
\hline \multirow{2}{*}{ REVIEW COMMENT RECORD (RCR) } & 10/3/96 & $\begin{array}{l}\text { 2. Review No. } \\
\text { Whitehurst }\end{array}$ \\
\hline & $\begin{array}{l}\text { 3. Project No. } \\
\text { W-441-C1 }\end{array}$ & 1 of 12 \\
\hline
\end{tabular}

\begin{tabular}{|l|l|l|l|l|}
\hline 5. Docurnent Number(s)/Title(s) & $\begin{array}{l}\text { 6. Program/Project } \\
\text { Building Number } \\
\text { CVD }\end{array}$ & $\begin{array}{l}\text { 7. Reviewer } \\
\text { CVD 90\% DESIGN REVIEW DCS AND } \\
\text { INSTRUMENT REVIEW }\end{array}$ & R. Whitehurst & 8. Organization/Group \\
DESH Technical Integration & R3-86/376-4663 \\
\hline
\end{tabular}

17. Comment Submittal Approval:

Organization Manager (Optional)

10. Agreement with indicated comment disposition(s)
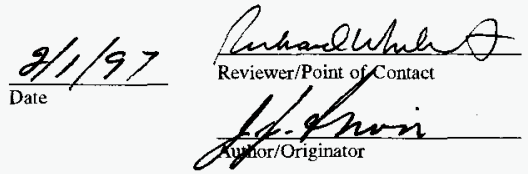

11. CLOSED

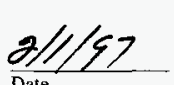

Date

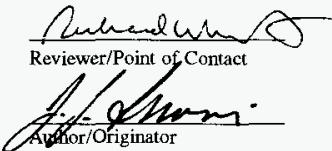

\begin{tabular}{|c|c|c|c|c|c|}
\hline \multirow[t]{2}{*}{$\overline{0}$} & $\begin{array}{l}12 . \\
\text { Item }\end{array}$ & $\begin{array}{l}\text { 13. Comment(s)/Discrepancy(s) (Provide technical justification for the comment and } \\
\text { detailed recommendation of the action required to correct/ resolve the discrepancy/problem } \\
\text { indicated.) }\end{array}$ & $\begin{array}{l}14 . \\
\text { Hold } \\
\text { Point }\end{array}$ & 15. Disposition (Provide justification if NOT accepted.) & $\begin{array}{l}16 . \\
\text { Status }\end{array}$ \\
\hline & 1 & $\begin{array}{l}\text { DCS Spec W-411: } 60 \% \text { \#6: Color coding for electrical equipment, } \\
\text { including CRT displays shall be per ICF A/E Standard "GE-COLR-01". } \\
\text { Did not locate in DCS Spec for DCS. }\end{array}$ & & $\begin{array}{l}\text { Agree. RW: changes will be become part of the DESH DCS } \\
\text { procurement action, added to CM Action List (DCS items). } \\
\text { CSRS will be generated by DCS supplier during Title III. }\end{array}$ & Accept \\
\hline & 2 & $\begin{array}{l}\text { H-2-82291 Sht } 1 \text { and DCS Spec W-411-P7\&8: An alarm is needed to } \\
\text { notify the Rad Worker room if a RM alarm is received. The Spec still } \\
\text { refers to the RAD PC, which has been deleted from } 82291 \text {. }\end{array}$ & & $\begin{array}{l}\text { Agree. RW: Disposition remains to be verified, will verify } \\
\text { upon release of the DCS Spec, added to CM Action List (DCS } \\
\text { items). }\end{array}$ & Accept \\
\hline 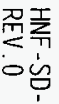 & 3 & $\begin{array}{l}\text { DCS Spec W-411-P7 and H-2-82291 Sht } 1,60 \% \text { \#8: Change the } \\
\text { MANAGEMENT INFO SYSTEM printer to Color Graphics Printer, same } \\
\text { as operator printer. }\end{array}$ & & $\begin{array}{l}\text { Agree. RW: Disposition remains to be verified, will verify } \\
\text { upon release of the DCS Spec, drawing requires a ECN, added } \\
\text { to CM Action List. }\end{array}$ & Accept \\
\hline 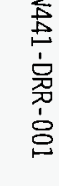 & 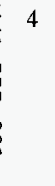 & $\begin{array}{l}\text { DCS Spec W-411-P16, 17: Paragraphs 3.3.4.5, 3.3.6.1 refer to a "log } \\
\text { printer" and "event print outs". I believe this refers to the use or to the } \\
\text { "alarm printer", which was deleted. Please search for all references to } \\
\text { either alarm or log printer and review for impact. The color graphic } \\
\text { printers will be used for on-demand printouts or possibly "reports", no } \\
\text { automatic logging to printers will occur. }\end{array}$ & & $\begin{array}{l}\text { Agree. RW: Disposition remains to be verified, will verify } \\
\text { upon release of the DCS Spec, added to CM Action List (DCS } \\
\text { items). }\end{array}$ & Accept \\
\hline
\end{tabular}




\begin{tabular}{|l|l|l|}
\hline \multirow{2}{*}{ REVIEW COMMENT RECORD (RCR) } & $\begin{array}{l}\text { 1. Date } \\
\text { 2. Review No. } \\
\text { Whitehurst }\end{array}$ \\
\cline { 2 - 4 } & $\begin{array}{l}\text { 3. Project No. } \\
\text { W-441-C1 }\end{array}$ & $\begin{array}{l}\text { 4. Page } \\
2\end{array}$ \\
\hline
\end{tabular}

\begin{tabular}{|c|c|c|c|c|}
\hline $\begin{array}{l}12 . \\
\text { Item }\end{array}$ & $\begin{array}{l}\text { 13. Conment(s)/Discrepancy(s) (Provide technical justification for the comment and } \\
\text { detailed recommendation of the action required to conrect/ resolve the discrepancy/problem } \\
\text { indicated.) }\end{array}$ & $\begin{array}{l}14 . \\
\text { Hold } \\
\text { Point }\end{array}$ & 15. Disposition (Provide justification if NOT accepted.) & $\begin{array}{l}16 . \\
\text { Status }\end{array}$ \\
\hline 5 & $\begin{array}{l}\text { H-2-82291 Sht 1, it is unclear if a laptop computer can be connected to the } \\
\text { "Communication Line Taps" for each of the bays and equipment room. } \\
\text { Could a note be added that states this capability? }\end{array}$ & & $\begin{array}{l}\text { No direction to proceed with the laptop scope change. RW: } \\
\text { Verification of Laptop requirements added to CM Action List. }\end{array}$ & Accept \\
\hline 6 & $\begin{array}{l}\text { H-2-82291 Sht } 1,60 \% \text { \#11: Remove "CPU" from "PLC CPU" this will } \\
\text { cause confusion. }\end{array}$ & & Agree. RW: Tthis item added to CM Action List. & Accept \\
\hline 7 & $\begin{array}{l}\text { Unknown Document, } 60 \% \# 12 \text { : Add a video monitoring switcher to the } \\
\text { Rad Worker Room for viewing of any video signals coming from the } \\
\text { operating areas. At } 90 \% \text { could not locate this requirement or connection. }\end{array}$ & & Agree. RW: This item added to CM Action List. & Accept \\
\hline 8 & $\begin{array}{l}\text { DCS Spec W-411-P6: } 60 \% \text { \#24: With regards to the control room operator } \\
\text { stations, a place to store the keyboard (pull out drawer or other hidden } \\
\text { location), and a location below the table space for the CPU should be } \\
\text { provided. This will provide an open working area for Ops, hide all the } \\
\text { cables to/from the CPU and provide a good viewing size for the operator. } \\
\text { At } 90 \% \text { it is still unclear if these things have been taken care of. In the } \\
\text { DCS spec it does call for a tower computer for floor installation, will there } \\
\text { be a good location for the computer for access and for movement by Ops. } \\
\text { I assume the Jazz drive is internal, it doesn't say right now. }\end{array}$ & & $\begin{array}{l}\text { Agree. RW: Disposition remains to be verified, will verify } \\
\text { upon release of the DCS Spec, added to CM Action List (DCS } \\
\text { items). }\end{array}$ & Accept \\
\hline 9 & $\begin{array}{l}\text { DCS Spec W-411-P5: The range for operating temperature and humidity } \\
\text { is much smaller than the general specs for a Modicon PLC. Shouldn't they } \\
\text { be } 32-140 \text { deg F and } 0-95 \% \text { RH? }\end{array}$ & & Agree, Agree. & Accept \\
\hline
\end{tabular}




\begin{tabular}{|c|c|c|c|}
\hline 1dəว๖ & 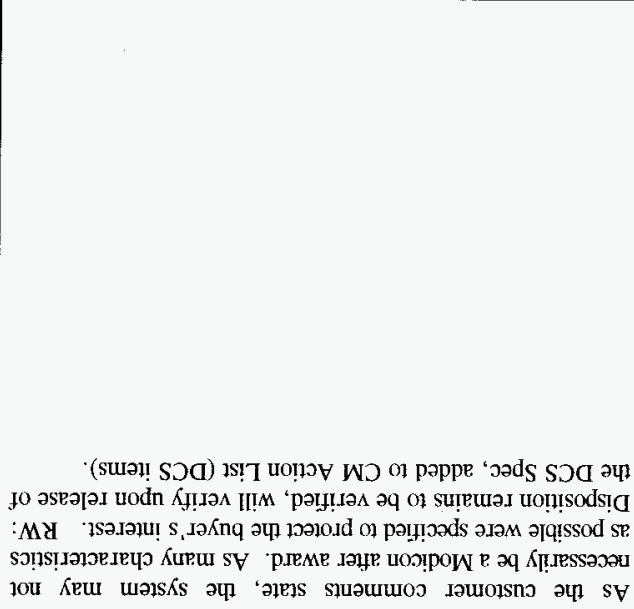 & & 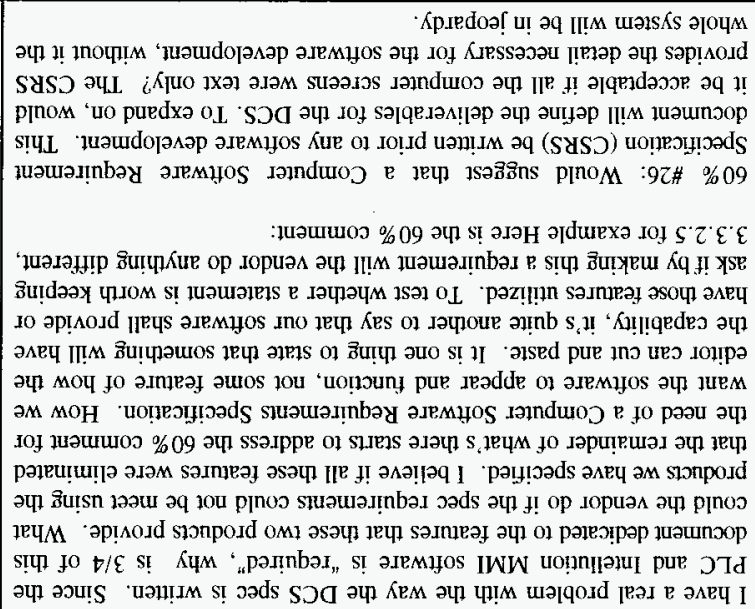 \\
\hline $\begin{array}{r}\text { Sก'घ]S } \\
9 \text { II }\end{array}$ & 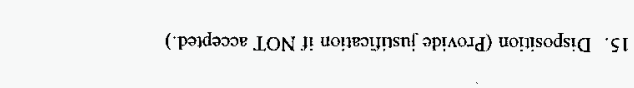 & 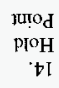 & 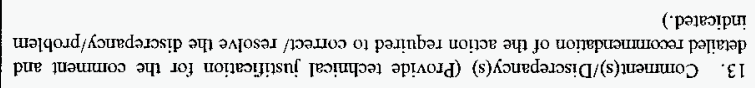 \\
\hline
\end{tabular}

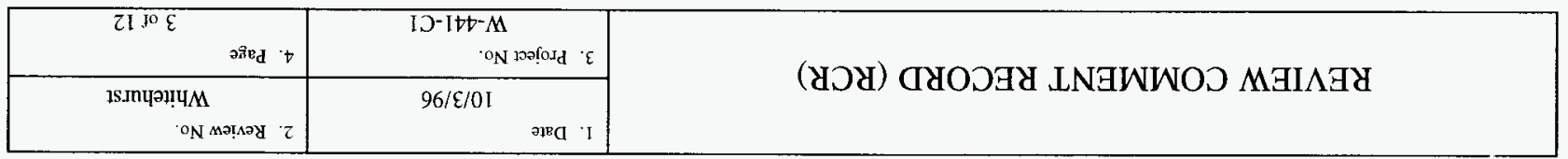




\begin{tabular}{|c|c|c|c|c|}
\hline 1dอวอท & 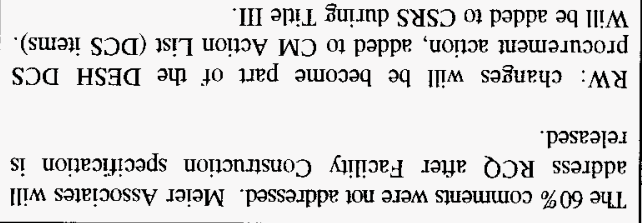 & & 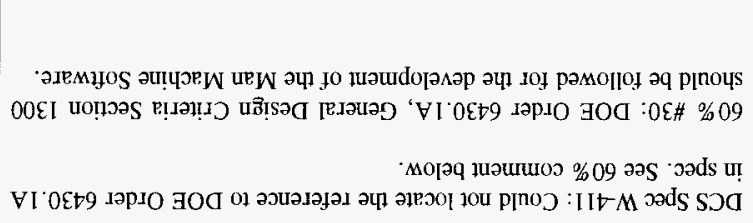 & EI \\
\hline qdəวэท & 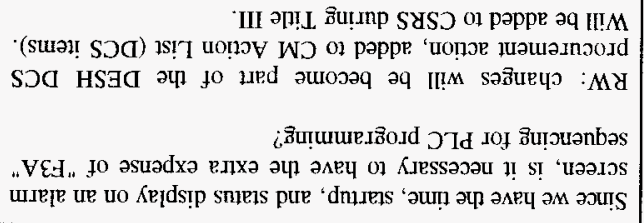 & & 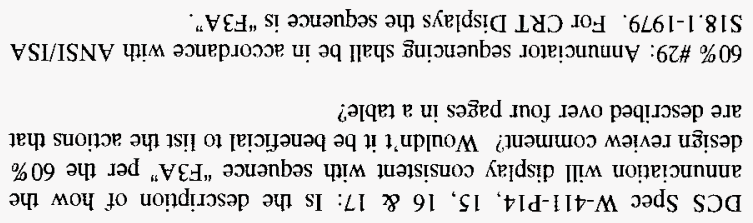 & ZI \\
\hline IdəววV & 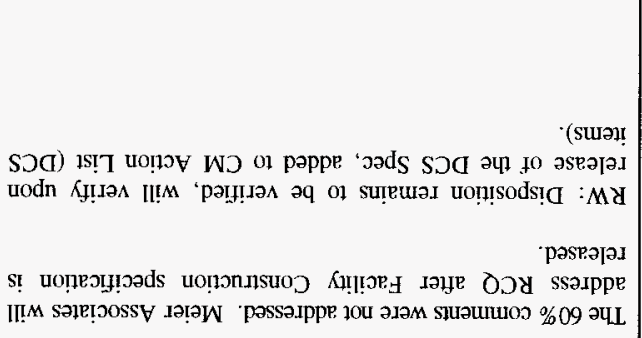 & & 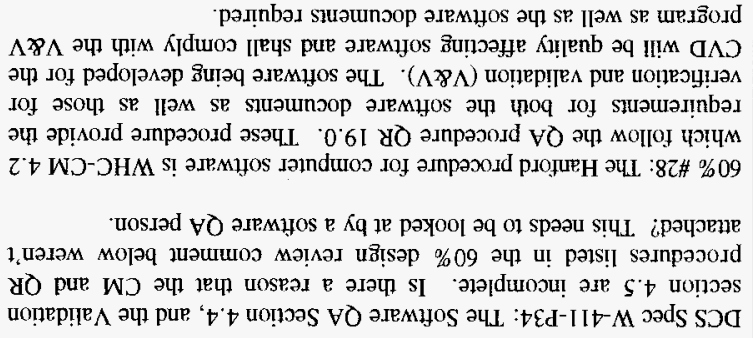 & II \\
\hline $\begin{aligned} \operatorname{sil} 1 S \\
91\end{aligned}$ & 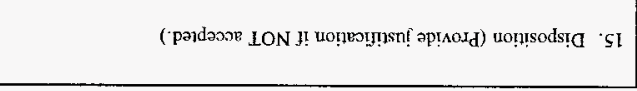 & $\begin{array}{r}1 \mathrm{lmod} \\
\mathrm{plOH} \\
+1 \mathrm{Ol}\end{array}$ & 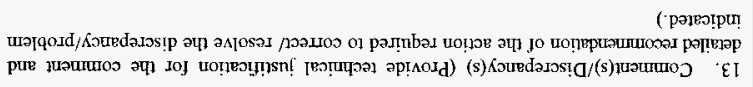 & $\begin{aligned} \text { யəII } \\
\text { ¿iI }\end{aligned}$ \\
\hline \multicolumn{3}{|c|}{$\mathrm{O}^{\mathrm{N}}$ } & \multirow{2}{*}{ 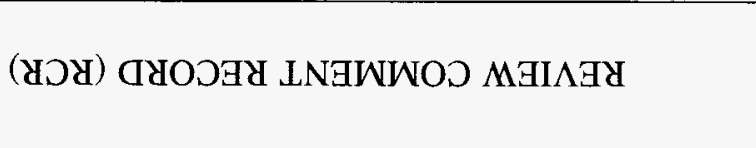 } & \\
\hline & 96/E/0I & & & \\
\hline
\end{tabular}




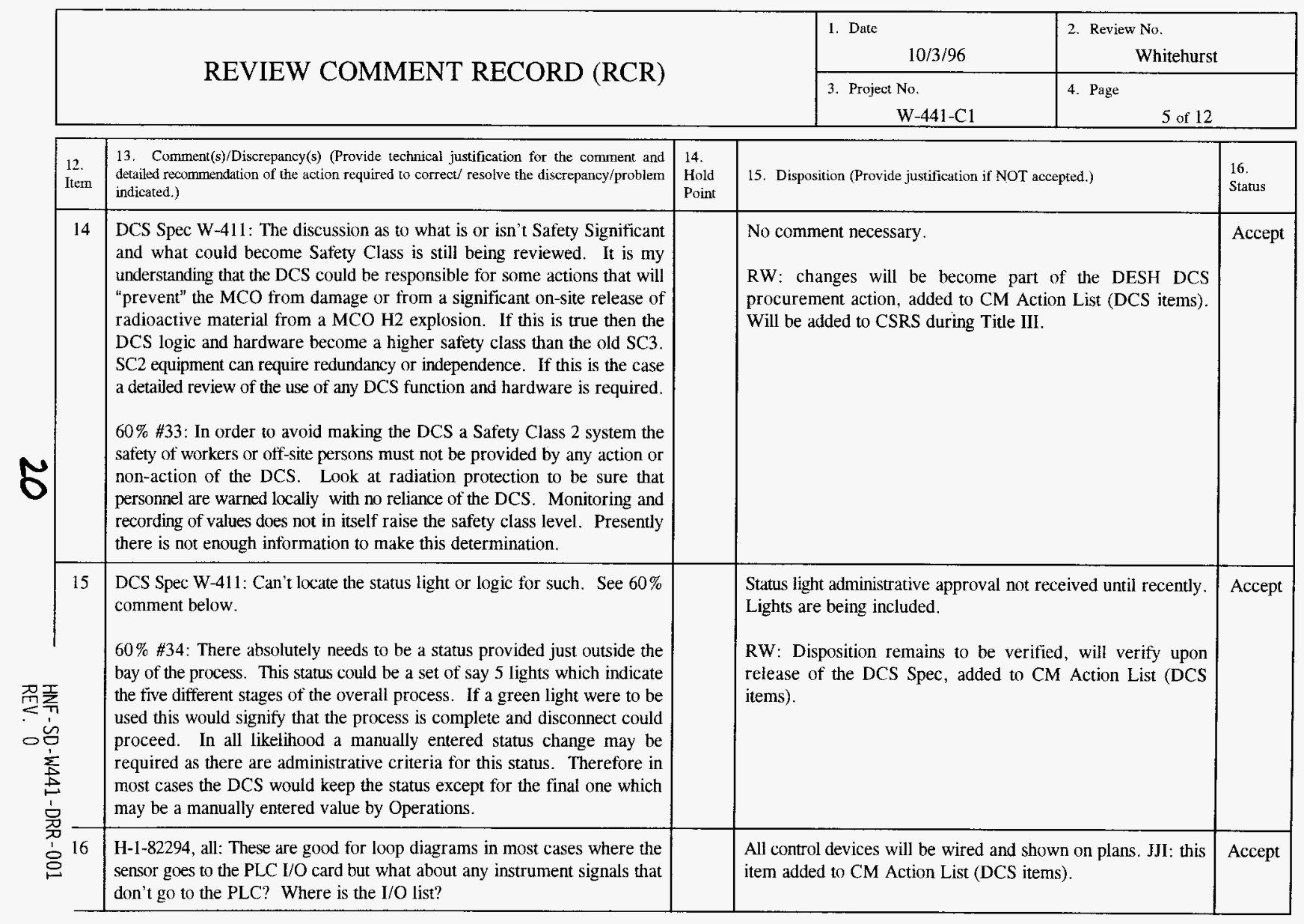




\begin{tabular}{|l|l|l|}
\hline \multirow{2}{*}{ REVIEW COMMENT RECORD (RCR) } & $\begin{array}{l}\text { 1. Date Review No. } \\
\text { Whitehurst }\end{array}$ \\
\cline { 2 - 3 } & $\begin{array}{c}\text { 3. Project No. } \\
\text { W-441-Cl }\end{array}$ & $\begin{array}{l}\text { 4. Page } \\
6 \text { of } 12\end{array}$ \\
\hline
\end{tabular}

12. 13. Comment(s)/Discrepancy(s) (Provide technical justification for the comment and It. detailed recommendation of the action required to correct/ resolve the discrepancy/problem

17 H-1-82163 sht 1: For obvious interlocks, like the one reported for SOV3103 from the LSH 3106 there should be a dotted line showing this electronic connection. This is no different from a HS to ZS electronic connection.

Shouldn't the logic diagram be referenced on the P\&IDs by note specific to the page the logic is on?

The method of showing this type of interlock on H-1-82164 is close if not adequate, still a dotted line would be nice.

$60 \% \# 38$ : It appears that a failure of the level control for TW-TK-3112 would result in sending contaminated water down the Process Vent system.

\section{4.} Hold Point
15. Disposition (Provide justification if NOT accepted.)

Dotted lines will be shown for devices that are hard-wired

routine to stop water in if there is a preset difference between leve elements. Also, would it be a good thing to provide a local level indication or sight glass? H-2-826763 Sht 1

18 DCS Spec W-411-P17: I have a concern that the only annunciator alarm is a PC speaker. In fact it appears that the two operator and one engineering station will alarm simultaneously and have to be individually acknowledged. It is suggested that a Sonalert alarm and PLC originated contact/power be provided so that any station can ack an alarm and that a more formidable alarm be used. Paragraph 3.3.4.8 uses the word HORN, is this true?

DCS Spec W-411: There is a desire to annunciate the Radiation Monitoring alarm in the RM room. A PC speaker would be adequate.

20 DCS Spec W-411-P3: The spec (3.1.4) presently uses "shall" for how many remote bases there are, should this be preferred or recommended so that the final design isn't restricted should another base be prudent? interlocked. If required, we could negotiate individual loops. Otherwise, logic diagrams are sufficient.

Logic is on a per output (inst. Loop) basis at present.

Number of shown interlocks limited because of great number of actual interlocks would severely clutter P\&ID's.

Second element provided.

Intended operation is to periodically calibrated to $100 \%$ on LI3104 with LAH-3106.

Didn't include because of redundant check and operators are not present. Only good for calibration which can be done other ways.

It is not part of the scope to have a separate "horn". The Accept specification call for simultaneous acknowledgement. RW: This item added to CM Action List (DCS items), operations to review.

Agree. RW: This item added to CM Action List (DCS items)

Will review each case and change wording if possible. RW: Disposition remains to be verified, will verify upon release of the DCS Spec, added to CM Action List (DCS items). 


\begin{tabular}{|c|c|c|}
\hline \multirow{2}{*}{ REVIEW COMMENT RECORD (RCR) } & $\begin{array}{l}\text { 1. Date } \\
10 / 3 / 96\end{array}$ & $\begin{array}{l}\text { 2. Review No. } \\
\text { Whitehurst }\end{array}$ \\
\hline & $\begin{array}{l}\text { 3. Project No. } \\
\text { W-441-C1 }\end{array}$ & 4. Page 7 of 12 \\
\hline
\end{tabular}

\begin{tabular}{|c|c|c|c|c|}
\hline $\begin{array}{l}12 . \\
\text { ltemn }\end{array}$ & $\begin{array}{l}\text { 13. Comment(s)/Discrepancy(s) (Provide technical justification for the comment and } \\
\text { detailed recommendation of the action required to comect/resolve the discrepancy/problem } \\
\text { indicated.) }\end{array}$ & $\begin{array}{l}14 . \\
\text { Hold } \\
\text { Point }\end{array}$ & 15. Disposition (Provide justification if NOT accepted.) & $\begin{array}{l}16 . \\
\text { Status }\end{array}$ \\
\hline 21 & $\begin{array}{l}\text { DCS Spec W-411-P3: The temperature and humidity specs for the PLC on } \\
\text { page } 5 \text { refers to } 40-100 \text { deg. F. The general environmental specs for } \\
\text { Modicon are } 32-140 \text { deg. F and } 0-95 \% \text { RH. Resolve difference and update } \\
\text { as necessary to place the appropriate operational limits in spec. }\end{array}$ & & Agree. Same as comment 9 . & Accept \\
\hline 22 & $\begin{array}{l}\text { H-1-82161, 82294: I think it would be a good idea to provide a switch to } \\
\text { "Fail Open" the purge gas valves to the MCOs, SOV } 1 * 21 \text {, SOV } 1 * 05 \text {, } \\
\text { SOV } 1 * 09 \text {. If we are taking credit in safety space for the valves failing } \\
\text { open on a loss of power, a switch would provide an easy Operator method } \\
\text { to open the valves should the process be halted for other than a loss of } \\
\text { power. This switch could be located at each of the bay remote I/O panel. }\end{array}$ & & RW: Changes are made to safety class controls. & Accept \\
\hline 23 & $\begin{array}{l}\text { DCS Spec W-411: Should a PLC card have to be replaced, how would user } \\
\text { power for the contacts or inputs be removed? This will have to be done } \\
\text { whether or not the cards themselves can be removed and reinstalled hot. }\end{array}$ & & The design calls for $115 \mathrm{~V}$ plug receptacles for PLC power. & Accept \\
\hline 24 & $\begin{array}{l}\text { H-1-82299 and } 82300 \text { are not user friendly. Without a list of what the tag } \\
\text { names are there is no way to understand what the logic is doing. I would } \\
\text { love to see common language used (besides the tag name) like VALVE } \\
\text { OPEN, NO LEVEL ALARM or LSH=0 or LSH CLEAR. Would it hurt } \\
\text { to have a brief title for each interlock. Take SOV } 3 * 03 \text { on page } 13 \text {, "SOV } \\
3^{*} 03 \text { DI Water Isolation to TW-TK-3112" or "... to Tempered Water } \\
\text { Storage Tank"? What about a brief description of what function it serves, } \\
\text { like interlock with tank level? }\end{array}$ & & $\begin{array}{l}\text { RW: the drawing will not be used, instead an overall design } \\
\text { description, individual logic details and equipment operational } \\
\text { matrix will be generated. The logic diagrams will be provided } \\
\text { by the DCS sottware vendor. These items added to CM Action } \\
\text { List. }\end{array}$ & Accept \\
\hline 25 & $\begin{array}{l}\text { H-1-82299 and } 82300 \text {, These sheets have nothing to indicate what function } \\
\text { they serve, since they aren't SOV like comment } 24 \text { deals with. I don't } \\
\text { know what they do and why they are separate sheets. The drawing title is } \\
\text { worthless. }\end{array}$ & & See disposition for comment 24 . & Accept \\
\hline
\end{tabular}




\begin{tabular}{|l|l|l|}
\hline \multirow{2}{*}{ REVIEW COMMENT RECORD (RCR) } & $\begin{array}{l}\text { 1. Date } \\
10 / 3 / 96\end{array}$ & $\begin{array}{c}\text { 2. Review No. } \\
\text { Whitehurst }\end{array}$ \\
\cline { 2 - 4 } & $\begin{array}{l}\text { 3. Project No. } \\
\text { W-441-C1 }\end{array}$ & $\begin{array}{l}\text { 4. Page } \\
8 \text { of } 12\end{array}$ \\
\hline
\end{tabular}

\begin{tabular}{|c|c|c|c|c|}
\hline $\begin{array}{ll}12 \\
\text { Ite }\end{array}$ & $\begin{array}{l}\text { 13. Comment(s)/Discrepancy(s) (Provide echnical justification for the comment and } \\
\text { detailed recommendation of the action required to correct/ resolve the discrepancy/problem } \\
\text { indicated.) }\end{array}$ & \begin{tabular}{|l|l}
14. \\
Hold \\
Point
\end{tabular} & 15. Disposition (Provide justification if NOT accepted.) & $\begin{array}{l}16 . \\
\text { Stanus }\end{array}$ \\
\hline 2 & $\begin{array}{l}\text { DCS Spec W-411-P6: Step } 3.3 .1 .1 \text { calls out for fans "required". Do we } \\
\text { want to leave it up to the contractor to provide cooling fans in the remote } \\
\text { I/O and PLC cabinets? I would prefer requiring fans. }\end{array}$ & & $\begin{array}{l}\text { Modicon Engineers do not feel there is a need for fans. If still } \\
\text { desired, provide formal request through Merrick. RW: } \\
\text { changes will be become part of the DESH DCS procurement } \\
\text { action. }\end{array}$ & Accept \\
\hline 2 & $\begin{array}{l}\text { DCS Spec W-411-P6: Step 3.3.1.3, add "Millennium" after the Micron } \\
\text { computer and "Bravo" after the AST. These are both Hanford standards. }\end{array}$ & & Agree. & Accept \\
\hline 2 & $\begin{array}{l}\text { DCS Spec W-411-P6: Step 3.3.1.3, add a CD ROM } 8 X \text { speed for use with } \\
\text { software, almost all MMI is CD ROM based. }\end{array}$ & & $8 \mathrm{X} \mathrm{CD} \mathrm{ROM} \mathrm{is} \mathrm{specified.}$ & Accept \\
\hline 2 & $\begin{array}{l}\text { DCS Spec W-411-P7: Step 3.3.2.1, add the requirement that software be } \\
\text { CD ROM when available. Add ACAD Lite to table of required software. } \\
\text { Also, make sure Access is available from MS Office. Both these products } \\
\text { are necessary for Process M. The table has a reference to the Radiation } \\
\text { Worker PC. }\end{array}$ & & $\begin{array}{l}\text { RW: changes will he become part of the DESH DCS } \\
\text { procurement action, Process M, and Autocad Lt will not be } \\
\text { required. Will be added to CSRS during Title III. }\end{array}$ & Accept \\
\hline 3 & $\begin{array}{l}\text { DCS Spec W-411-P7: Step 3.3.1.8, why are parallel printer bus and } \\
\text { TCP/IP needed for the printers? The graphic printers come from the "E- } \\
\text { NET HUB". I assume that means TCP/IP and the parallel is just a } \\
\text { standard interface we want to specify but are using at this time. }\end{array}$ & & $\begin{array}{l}\text { Yes. RW: changes will be become part of the DESH DCS } \\
\text { procurement action, added to CM Action List (DCS items). } \\
\text { Will not require two parallel ports since printer will be } \\
\text { TCP/IP. Will be added to CSRS during Title III. }\end{array}$ & Accept \\
\hline & $\begin{array}{l}\text { DCS Spec W-411-P7: Step 3.3.1.8, this step is really } 3.3 .1 .9 \text { since the one } \\
\text { above is } 8 \text {. In addition, this printer is NOT a LJ5 it is the same as the one } \\
\text { in 3.3.1.8, Tektronix not Tektronix. }\end{array}$ & & $\begin{array}{l}\text { Agree. RW: changes will be become part of the DESH DCS } \\
\text { procurement action, added to CM Action List (DCS items). }\end{array}$ & Accept \\
\hline
\end{tabular}




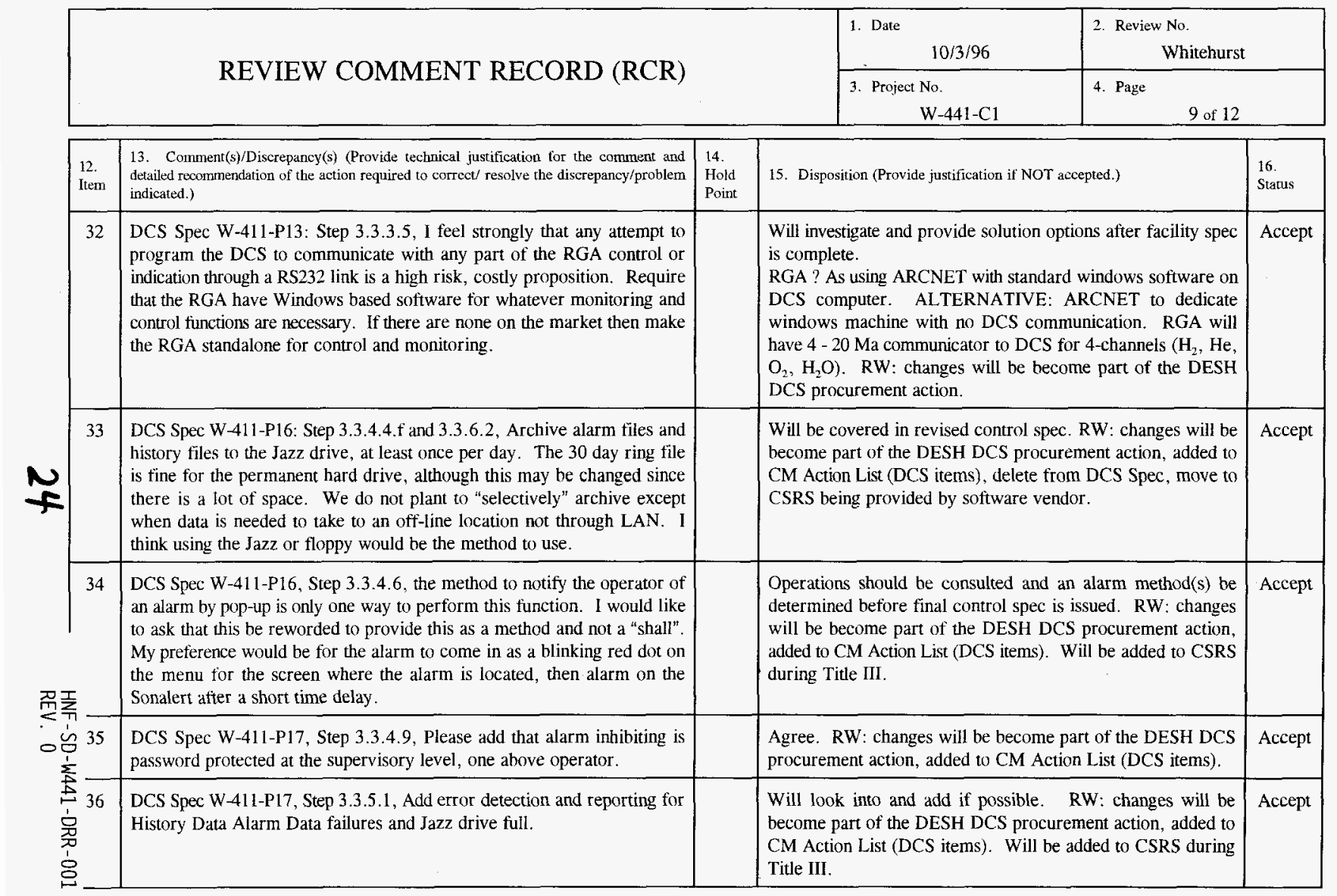




\begin{tabular}{|l|l|l|}
\hline \multirow{2}{*}{ REVIEW COMMENT RECORD (RCR) } & $\begin{array}{l}\text { 1. Date } \\
10 / 3 / 96\end{array}$ & $\begin{array}{c}\text { 2. Review No. } \\
\text { Whitehurst }\end{array}$ \\
\cline { 2 - 4 } & $\begin{array}{l}\text { 3. Project No. } \\
\text { W-441-C1 }\end{array}$ & $\begin{array}{l}\text { 4. Page } \\
10 \text { of } 12\end{array}$ \\
\hline
\end{tabular}

\begin{tabular}{|c|c|c|c|c|}
\hline $\begin{array}{l}12 . \\
\text { Item }\end{array}$ & $\begin{array}{l}\text { 13. Cornment(s)/Discrepancy(s) (Provide technical justification for the comment and } \\
\text { detailed recommendation of the action required to correct/ resolve the discrepancy/problem } \\
\text { indicated.) }\end{array}$ & $\begin{array}{l}14 . \\
\text { Hold } \\
\text { Point }\end{array}$ & 15. Disposition (Provide justification if NOT accepted.) & $\begin{array}{l}16 . \\
\text { Status }\end{array}$ \\
\hline 37 & $\begin{array}{l}\text { DCS Spec W-411-P18, Step 3.3.7.1, remove the word analog for trending. } \\
\text { We need to be able to trend any variable, so selected for trending, even } \\
\text { digital. I assume this whole section describes the capability of the } \\
\text { Intellution trending routine. If this is so, delete all the extra that won't } \\
\text { effect the writing of the software. If not clearly define what trends are } \\
\text { required and what process events will initiate different trending } \\
\text { requirements. How is the contractor going to respond to this requirement? } \\
\text { Excel is the site standard, remove or a buyer equal. }\end{array}$ & & $\begin{array}{l}\text { The wording will be refined. RW: changes will be become } \\
\text { part of the DESH DCS procurement action, added to CM } \\
\text { Action List (DCS items). Will be added to CSRS during Title } \\
\text { III. }\end{array}$ & Accept \\
\hline 38 & $\begin{array}{l}\text { DCS Spec W-411-P18, Step } 3.3 .7 .1 \text {, same comment as the above, is this } \\
\text { more features? A minimum of } 8 \text { variable trends shall be displayed on } \\
\text { one graph. Should this be that at least } 8 \text { trends can be displayed? } \\
\text { sounds like all trends have to have } 8 \text { even when this doesn't make sense. } \\
\text { Add to end: "Scale values in engineering units shall be updated to reflect } \\
\text { the selected trend". This is needed so that when temperature and flow } \\
\text { are both trended together that when you want to view the temperature } \\
\text { trend the scale values range from } 0-1500 \text { deg F. When flow is selected } \\
\text { the scale should be } 0-600 \text { gpm. I do not want } 0-100 \% \text { for every } \\
\text { variable, this never works as every range varies. }\end{array}$ & & $\begin{array}{l}\text { The wording will be refined. RW: changes will be become } \\
\text { part of the DESH DCS procurement action, added to CM } \\
\text { Action List (DCS items). Will be added to CSRS during Title } \\
\text { III. }\end{array}$ & Accept \\
\hline 39 & $\begin{array}{l}\text { DCS Spec W-411-P18, Step 3.3.8.2, what control does the contractor } \\
\text { have on the variable update times, is this another example of the PLC } \\
\text { and LAN parameters that he has no control over? }\end{array}$ & & $\begin{array}{l}\text { Again, in case Modicon is not used, there will be benchmarks } \\
\text { for the design. RW: Disposition remains to be verified, will } \\
\text { verify upon release of the DCS Spec. }\end{array}$ & Accept \\
\hline 40 & $\begin{array}{l}\text { DCS Spec W-411-P20 to } 25 \text {, Step 3.3.9.1 to 3.3.9.17, what is the } \\
\text { purpose of these pages? Does this describe Process M software? }\end{array}$ & & $\begin{array}{l}\text { In case Modicon is not used, there will be benchmarks for the } \\
\text { design. }\end{array}$ & Accept \\
\hline 41 & $\begin{array}{l}\text { DCS Spec W-411-P25, Step 3.3.10.2, The enclosure should be NEMA } \\
4 \text { or } 4 \text { X. }\end{array}$ & & All enclosures are indoors and NEMA 12. & Accept \\
\hline
\end{tabular}




\begin{tabular}{|l|l|l|l|}
\hline \multirow{2}{*}{ REVIEW COMMENT RECORD (RCR) } & $\begin{array}{l}\text { 1. Date } \\
\text { 2. Review No. } \\
\text { Whitehurst }\end{array}$ & \multicolumn{2}{|c|}{$10 / 3 / 96$} \\
\cline { 2 - 4 } & 3. Project No. \\
W-441-C1 & 4. Page \\
\hline
\end{tabular}

\begin{tabular}{|c|c|c|c|c|}
\hline $\begin{array}{l}12 . \\
\text { Item }\end{array}$ & $\begin{array}{l}\text { 13. Comment(s)/Discrepancy(s) (Provide technical justification for the comment and } \\
\text { detailed recommendation of the action required to correct/ resolve the discrepancy/problem } \\
\text { indicated.) }\end{array}$ & $\begin{array}{l}14 . \\
\text { Hold } \\
\text { Point }\end{array}$ & 15. Disposition (Provide justification if NOT accepted.) & $\begin{array}{l}16 . \\
\text { Status }\end{array}$ \\
\hline 42 & $\begin{array}{l}\text { DCS Spec W-411-P26, Step } 3.3 .10 .8 \text {, I think we want open } \\
\text { thermocouple detection normally. Please change wording to indicate } \\
\text { that this is the standard configuration. }\end{array}$ & & $\begin{array}{l}\text { Agree. RW: changes will be become part of the DESH DCS } \\
\text { procurement action, added to CM Action List (DCS items). }\end{array}$ & Accept \\
\hline 43 & $\begin{array}{l}\text { DCS Spec W-411-P29, Step 3.6.5, Nameplates need to be white with } \\
\text { black letters, see comment } 1 .\end{array}$ & & $\begin{array}{l}\text { Agree. RW: changes will be become part of the DESH DCS } \\
\text { procurement action, added to CM Action List (DCS items). }\end{array}$ & Accept \\
\hline 44 & $\begin{array}{l}\text { DCS Spec W-411-P29, Step 3.9.2, Testing: } \\
\text { 1. A FAT, Factory Acceptance Test is one that will verify all internal } \\
\text { connection and the working of the PLC and computer interface. At this } \\
\text { time there are no sensors or outputs, everything is simulated or read } \\
\text { from a meter. The FAT does not represent V\&V testing other than } \\
\text { assurance the equipment is put together correctly. Don't put that every } \\
\text { step be witnessed and signed by Buyer, put that the buyer will witness } \\
\text { and sign test. Step n says alarm printer and RGA, there is no alarm } \\
\text { printer and the RGA is still in question. }\end{array}$ & & $\begin{array}{l}\text { The testing procedures will be reviewed and the wording } \\
\text { modified. RW: changes will be become part of the DESH } \\
\text { DCS procurement action, added to CM Action List (DCS } \\
\text { items). }\end{array}$ & Accept \\
\hline 45 & $\begin{array}{l}\text { DCS Spec P31 step 3.9.4, I do not believe that Factory testing satisfies } \\
\text { any Hanford V\&V criteria. Only the ATP in the plant, hooked up and } \\
\text { running does that. For some software a one-over-one may work but I } \\
\text { don't see that here. }\end{array}$ & & $\begin{array}{l}\text { The testing procedures will be reviewed and the wording } \\
\text { modified. RW: changes will be become part of the DESH } \\
\text { DCS procurement action, added to CM Action List (DCS } \\
\text { items). }\end{array}$ & Accept \\
\hline 46 & $\begin{array}{l}\text { DCS Spec P31 step } 3.9 .7 \& 8 \text {, This section needs serious work. What } \\
\text { we are looking for is a prepared ATP. I'd talk to Bob (Startup) Brown } \\
\text { or John Austin. We have some really good words on the preparation of } \\
\text { ATPs if you are interested, this isn't it. }\end{array}$ & & $\begin{array}{l}\text { The startup people will be included in the section rewrite. } \\
\text { JJI:DESH startup organization will develop the final ATP's. } \\
\text { RW: will be become part of the DESH DCS procurement } \\
\text { action, added to CM Action List (DCS items). }\end{array}$ & Accept \\
\hline
\end{tabular}




\begin{tabular}{|l|l|l|}
\hline \multirow{2}{*}{ REVIEW COMMENT RECORD (RCR) } & $\begin{array}{l}\text { 1. Date } \\
\text { 10/3/96 Review No. }\end{array}$ & \multicolumn{1}{c|}{ Whitehurst } \\
\cline { 2 - 4 } & $\begin{array}{l}\text { 3. Project No. } \\
\text { W-441-C1 }\end{array}$ & 4. Page \\
\hline
\end{tabular}

\begin{tabular}{|c|c|c|c|c|}
\hline $\begin{array}{l}12 . \\
\text { Item }\end{array}$ & $\begin{array}{l}\text { 13. Comment(s)/Discrepancy(s) (Provide technical justification for the comment and } \\
\text { detailed recommendation of the action required to correct/ resolve the discrepancy/problem } \\
\text { indicated.) }\end{array}$ & $\begin{array}{l}14 . \\
\text { Hold } \\
\text { Point }\end{array}$ & 15. Disposition (Provide justification if NOT accepted.) & $\begin{array}{l}16 . \\
\text { Status }\end{array}$ \\
\hline 47 & $\begin{array}{l}\text { DCS Spec P32 step 3.11.1.1, Too general on training, no real } \\
\text { objectives. See training department for examples since we just did a } \\
\text { data acquisition at K East not too long ago. }\end{array}$ & & $\begin{array}{l}\text { Agree. RW: changes will be become part of the DESH DCS } \\
\text { procurement action, added to CM Action List (DCS items). }\end{array}$ & Accept \\
\hline 48 & $\begin{array}{l}\text { DCS Spec P32 step } 3.11 .2 .1 \text {, Please search for the word Factory. To } \\
\text { my knowledge a FAT is done once, all other tests are not FATs. The } \\
\text { test in the plant prior to turnover is an ATP, Acceptance Test } \\
\text { Procedure. }\end{array}$ & & $\begin{array}{l}\text { Agree. RW: changes will be become part of the DESH DCS } \\
\text { procurement action, added to CM Action List (DCS items). }\end{array}$ & Accept \\
\hline 49 & $\begin{array}{l}\text { DCS Spec P32 step 4, seem like this is boiler plate stuff for the contract, } \\
\text { not a spec item. Check with procurement on this one. }\end{array}$ & & $\begin{array}{l}\text { Agree. RW: Disposition remains to be verified, will verify } \\
\text { upon release of the DCS Spec. }\end{array}$ & Accept \\
\hline 50 & $\begin{array}{l}\text { DCS Spec P36 step k., reference to RGA stuff I don't want, see } \\
\text { comment } 32 \text {. }\end{array}$ & & $\begin{array}{l}\text { The interface between DCS and RGA will be investigated. } \\
\text { RW: changes will be become part of the DESH DCS } \\
\text { procurement action. }\end{array}$ & Accept \\
\hline
\end{tabular}




\begin{tabular}{|l|l|l|}
\hline \multirow{2}{*}{ REVIEW COMMENT RECORD (RCR) } & $\begin{array}{l}\text { 1. Date } \\
\text { 2. Review No. } \\
\text { Whitehurst }\end{array}$ \\
\cline { 2 - 4 } & $\begin{array}{l}\text { 3. Project No. } \\
\text { W-441-C1 }\end{array}$ \\
\hline
\end{tabular}

\begin{tabular}{|l|l|l|l|l|}
\hline 5. Docurnent Number(s)/Title(s) & $\begin{array}{l}\text { 6. Program/Project/ } \\
\text { Building Number } \\
\text { CVD }\end{array}$ & $\begin{array}{l}\text { 7. Reviewer } \\
\text { CVD 90\% DESIGN REVIEW DCS AND } \\
\text { INSTRUMENT REVIEW }\end{array}$ & R. Whitehurst & 8. Organization/Group \\
\hline
\end{tabular}

17. Comment Submittal Approval:

Organization Manager (Optional)
10. Agreement with indicated comment disposition(s)

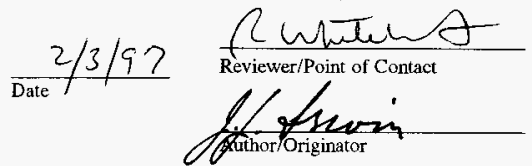

11 CLOSED

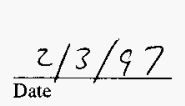

Riend witeh 0

Reviewer/Point of Contact

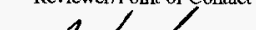

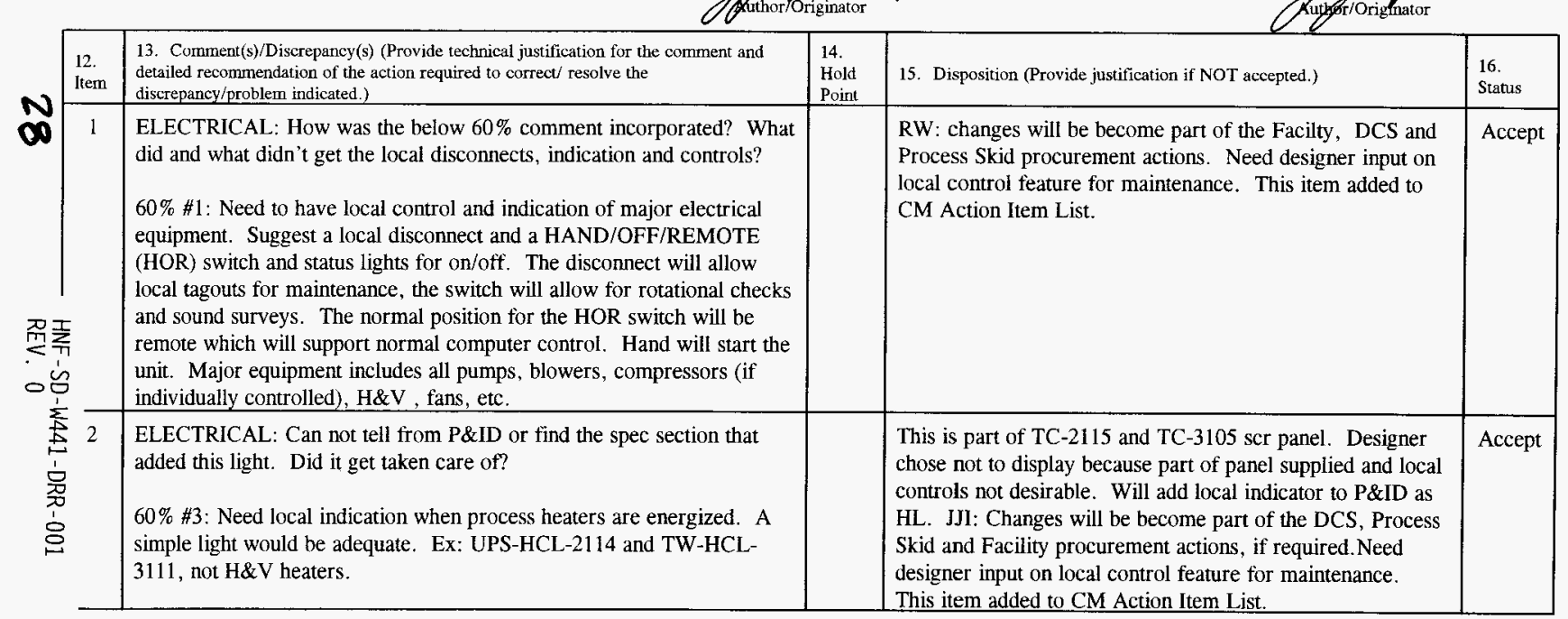




\begin{tabular}{|l|l|l|}
\hline \multirow{2}{*}{ REVIEW COMMENT RECORD (RCR) } & $\begin{array}{l}\text { 2. Date Review No. } \\
\text { Whitehurst }\end{array}$ & \multicolumn{1}{c|}{$10 / 3 / 96$} \\
\cline { 2 - 4 } & $\begin{array}{c}\text { 3. Project No. } \\
\text { W-441-Cl }\end{array}$ & 4. Page \\
\hline
\end{tabular}

\begin{tabular}{|c|c|c|c|c|}
\hline $\begin{array}{l}12 . \\
\text { Item }\end{array}$ & $\begin{array}{l}\text { 13. Comment(s)/Discrepancy(s) (Provide technical justification for the comment and } \\
\text { detailed recommendation of the action required to comect/ resolve the } \\
\text { discrepancy/problem indicated.) }\end{array}$ & $\begin{array}{l}14 . \\
\text { Hold } \\
\text { Point }\end{array}$ & 15. Disposition (Provide justification if NOT accepted.) & $\begin{array}{l}16 . \\
\text { Status }\end{array}$ \\
\hline 3 & $\begin{array}{l}\text { INSTRUMENTATION / ELECTRICAL: Could not find this in the } \\
\text { prints. Has this been implemented? } \\
60 \% \# 12 \text { : Add a video monitoring switcher to the Rad Worker Room for } \\
\text { viewing of any video signals coming from the operating areas. }\end{array}$ & & $\begin{array}{l}\text { RW: changes will be become part of the DESH CVDF } \\
\text { procurement action, if required. Need operations review for } \\
\text { requirements. This item added to CM Action Item List. }\end{array}$ & Accept \\
\hline 4 & $\begin{array}{l}\text { PROCESS: This general question has resurfaced after the safety issues } \\
\text { were identified. In particular, should there be a bypass around the } \\
\text { inerting lines to the MCO? Should both } \mathrm{N} 2 \text { and } \mathrm{He} / \mathrm{O} 2 \text { be so provided } \\
\text { with bypass valves? } \\
60 \% \text { \#21: Since there is no easy way to manually operate a GOV or } \\
\text { SOV in some cases it may be desired to have a bypass line and manual } \\
\text { valve around such valves. Review and assess the need, talk to Ops. }\end{array}$ & & $\begin{array}{l}\text { a. All automatic valves can be operated manually after } \\
\text { removing actuator - } 2 \text { bolts - in rear case that large flow is } \\
\text { necessary. } \\
\text { JJI: changes will be become part of the DESH DCS, Process } \\
\text { Skid and Facility procurement actions. Manual overides will } \\
\text { be incorporated into selected valves. Valves to be selected } \\
\text { based upon fault analysis now in work. } \\
\text { b. Because of multiple valves and paths for inert gas } \\
\text { addition, a stuck closed valve will not eliminate inerting } \\
\text { paths to MCO. }\end{array}$ & Accept \\
\hline 5 & $\begin{array}{l}\text { PROCESS AND INSTRUMENTATION Spec 17100: There is still no } \\
\text { indication that provisions for calibration have been incorporated. } \\
60 \% \# 37 \text { : For field instruments each shall have the capability to be } \\
\text { calibrated in place with isolation valves and test tees. This would } \\
\text { include flow, pressure, pressure differential and level. Where field } \\
\text { calibration is not possible means to easily remove and reinstall shall be } \\
\text { provided. }\end{array}$ & & $\begin{array}{l}\text { As indicated in responses to } 60 \% \text { : } \\
\text { 1. Pressure and OP are measurable by using open plug or } \\
\text { root gage valves with calibrates equipment. } \\
\text { 2. Level is checked by }<5 \% \text { difference between LI- } 3 * 04 \\
\text { and LAH-3*05. LSH }-2 * 23 \text { is for high level only for high } \\
\text { level alarm. VPS-TK } 2 * 16 \text { is verified MT by gas tlow into } \\
\text { RLW system. } \\
\text { 3. Flow is measured by liquid flows by tank delta level, gas } \\
\text { flows by setting gages to measure same flow and look for } \\
\text { agreement. Also FV- } 1 * 19 \text { is characterized valve. }\end{array}$ & Accept \\
\hline
\end{tabular}




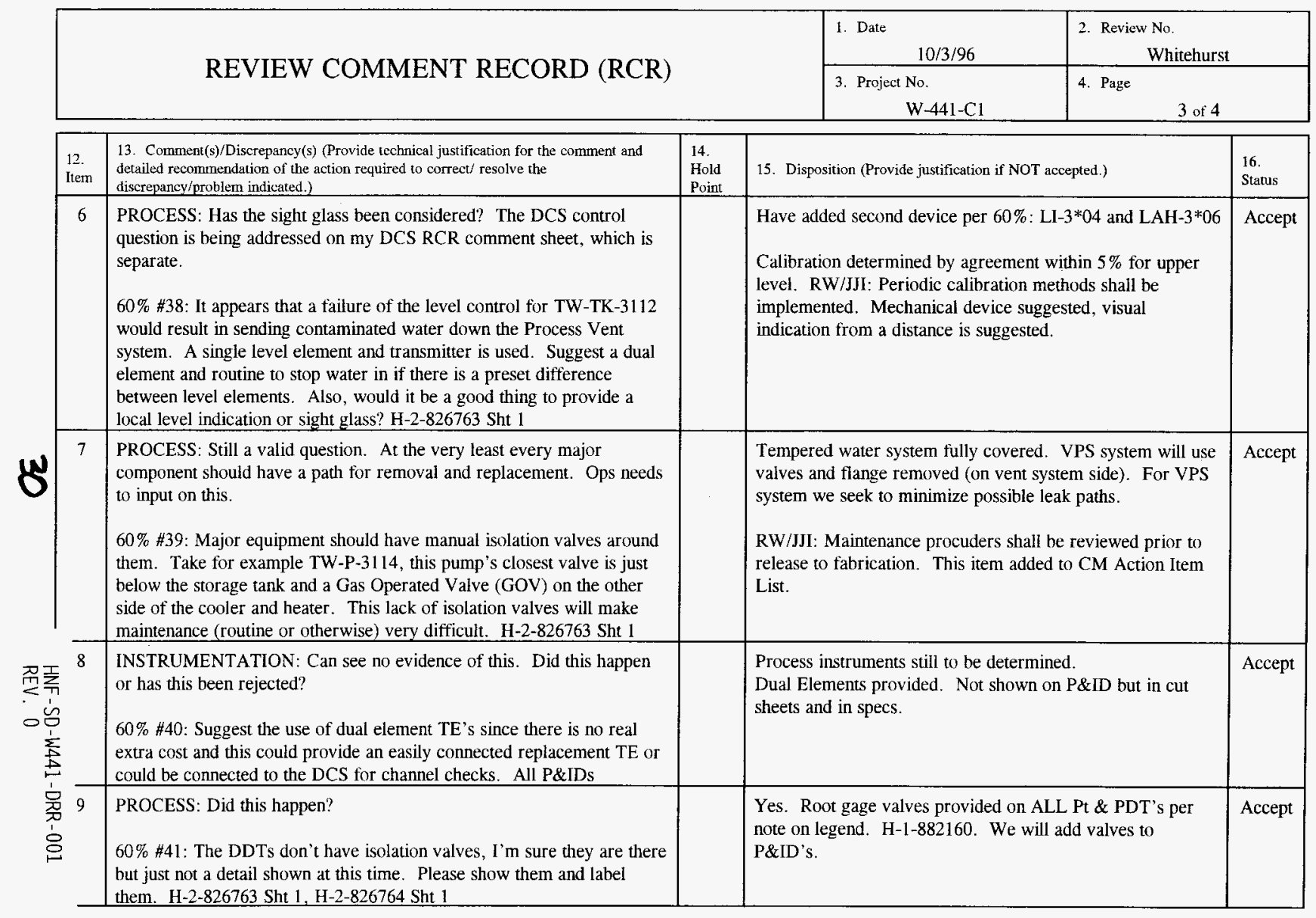




\begin{tabular}{|l|l|l|}
\hline \multirow{2}{*}{ REVIEW COMMENT RECORD (RCR) } & $\begin{array}{l}\text { 1. Date } \\
\text { 2. Review No. } \\
\text { Whitehurst }\end{array}$ & \multicolumn{1}{|c|}{$\begin{array}{c}\text { 10/3/96 } \\
\text { W-441-C1 }\end{array}$} \\
\cline { 2 - 4 }
\end{tabular}

\begin{tabular}{|c|c|c|c|c|}
\hline $\begin{array}{l}12 . \\
\text { Item }\end{array}$ & $\begin{array}{l}\text { 13. Comment(s)/Discrepancy(s) (Provide technical justification for the comment and } \\
\text { detailed recommendation of the action required to correct/ resolve the } \\
\text { discrepancy/problem indicated.) }\end{array}$ & $\begin{array}{l}14 . \\
\text { Hold } \\
\text { Point }\end{array}$ & 15. Disposition (Provide justification if NOT accepted.) & $\begin{array}{l}16 . \\
\text { Status }\end{array}$ \\
\hline 10 & $\begin{array}{l}\text { PROCESS: Did this happen? } \\
60 \% \# 42 \text { : H-2-826761 Sht } 1 \text { shows two pressure control valves without } \\
\text { isolation valves around them. I don't think I've ever seen this situation. } \\
\text { Please add isolation valves for both and label. }\end{array}$ & & $\begin{array}{l}\text { These valves are isolated by closing He and } \mathrm{N}_{2} \text { valves at } \\
\text { header and closing NV-* } 15 \text {. Maintenance change out can } \\
\text { then be effected. If trouble develops during operations, } \\
\text { there is no provision to rectify the rare problem other than } \\
\text { keeping NV-* } 15 \text { closed. RW/JJI: Maintenance concepts will } \\
\text { be reviewed prior to final fabrication release. Need designer } \\
\text { input on local control feature for maintenance. This item } \\
\text { added to CM Action Item List. }\end{array}$ & Accept \\
\hline 11 & $\begin{array}{l}\text { Spec } 17100 \text { seems to have a lot of blanks and " } x \text { 's" as placeholders for } \\
\text { information. I assume these will be filled in. Example: } 17100-3,2.3 .1 \\
\text { "Fabricate xx leak detectors...", 17100-15 table, all the tag numbers are } \\
\text { xxxx. }\end{array}$ & & Agree. Will be completed. & Accept \\
\hline
\end{tabular}




\begin{tabular}{|l|l|l|}
\hline \multirow{2}{*}{ REVIEW COMMENT RECORD (RCR) } & $\begin{array}{l}\text { 1. Date } \\
\text { Oct 4, 1996 }\end{array}$ & $\begin{array}{l}\text { 2. Review No. } \\
2\end{array}$ \\
\cline { 2 - 3 } & $\begin{array}{c}\text { 3. Project No. } \\
\text { CVD 90\% }\end{array}$ & $\begin{array}{l}\text { 4. Page } \\
1 \text { of } 5\end{array}$ \\
\hline
\end{tabular}

5. Document Number(s)/Title(s)
CVDF $90 \%$ Design Review, Const. Spec., Calc.
\& Drawings

\section{Program/Project/ Building Number \\ SNFP/CVDF/142K} \& Drawings

17. Comment Submittal Approval:

10. Agreement with indicated comment disposition(s)

Organization Manager (Optional)

$$
\frac{\text { Ap 3,1997 }}{\text { Date }}
$$$$
\text { C.C.nenzariar- }
$$

7. Reviewer

RE Merriman Reviewer/Point of Contact

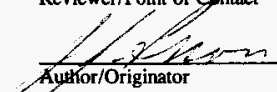

9. Location/Phone

TCPC/372-0514

* See Col. 16 "Status" Comments at end of document

\begin{tabular}{|l|ll}
\hline 12 & 13. Comment(s)/Discrepancy(s) (Provide technical justification for the comment and
\end{tabular} 12.
Item detailed recommendation of the action required to correct/ resolve the discrepancy/problem
indicated, indicated.)

1 General - NFPA Hazardous Classification. It was stated at the Design Review Meeting that no area outside the cask exceeds $25 \%$ of the Lower Flammable Limit for Hydrogen Gas. Thus all areas of the CVD are electrically "non-classified." Is this true?

2 Calculations:

Service Sizing Calculations; List loads per NEC 220-10(a) and (b) to facilitate feeder and service sizing and o.c. device sizing. Identify non-continuous and continuous load.

$\varnothing 气$

14.
Hold
Point

15. Disposition (Provide justification if NOT accepted.)

11. CLOSED

点 


\begin{tabular}{|c|c|c|}
\hline \multirow{2}{*}{ REVIEW COMMENT RECORD (RCR) } & $\begin{array}{l}\text { 1. Date } \\
\text { Oct 4, } 1996\end{array}$ & $\begin{array}{l}\text { 2. Review No. } \\
2 \\
\end{array}$ \\
\hline & $\begin{array}{l}\text { 3. Project No. } \\
\text { CVD } 90 \%\end{array}$ & 4. Page \\
\hline
\end{tabular}

\begin{tabular}{|c|c|c|c|c|}
\hline $\begin{array}{l}12 . \\
\text { Item }\end{array}$ & $\begin{array}{l}\text { 13. Comment(s)/Discrepancy(s) (Provide technical justification for the comment and } \\
\text { detailed recommendation of the action required to correct/ resolve the discrepancy/problem } \\
\text { indicated.) }\end{array}$ & $\begin{array}{l}14 . \\
\text { Hold } \\
\text { Point }\end{array}$ & 15. Disposition (Provide justification if NOT accepted.) & $\begin{array}{l}16 . \\
\text { Status }\end{array}$ \\
\hline 4 & $\begin{array}{l}\text { Transformer XTA Let-Thru Fault Calculation; Correct calculation for transformer } \\
\text { to be used. }\end{array}$ & & $\begin{array}{l}\text { The calculation is correct for the transformer selected based on the } \\
\text { service sizing calculation submitted. The fault current calculation will } \\
\text { be revised if directed to use a different transformer or revised load } \\
\text { calculations result in the selection of a different transformer. Utilizing } \\
\text { an existing dry type transformer is a change in scope from previous } \\
\text { direction and must be authorized by Jeff Filip and Kirk Ellard. Meier } \\
\text { Associates is awaiting written direction from Kirk Ellard, Merrick } \\
\text { Engineers. }\end{array}$ & OK \\
\hline 5 & Calculations not provided; voltage drop on worst case circuit. & & Agreed, will incorporate as suggested. & OK \\
\hline 6 & Calculations not provided; seismic for electrical equipment. & & Agreed, will incorporate as suggested. & OK \\
\hline 7 & $\begin{array}{l}\text { Specifications: } \\
\text { General - All electrical components/assemblies includes those supplied by Mech. } \\
\text { and others shall be labeled by a nationally approved testing laboratory. }\end{array}$ & & Agreed, will incorporate. & OK \\
\hline 8 & Section 01036, Part 3. ECN Form has changed from this format. & & & OK \\
\hline 9 & Section $08370-4 ; 2.3 .2$. Motor shall be suitable for operation on "60 Hz" power. & & Agreed. & OK \\
\hline 10 & $\begin{array}{l}\text { Section } 15010-3 ; 1.6 .2 \text { "Disc. SW \& motor starters provided by Electrical } \\
\text { contractor". Is this true in all cases? (Ref 15781-2, 2.1.3; 15790-2, 2.1.7) }\end{array}$ & & $\begin{array}{l}\text { Normally true. This section provides general information regarding } \\
15 X X X \text { sections. }\end{array}$ & OK \\
\hline 11 & $\begin{array}{l}\text { Section } 15010-3 ; 1.6 .4 .3 \text { ft. minimum clearance may not be correct, use } \\
\text { "clearance per NEC". }\end{array}$ & & Agreed, “NEC" added. & OK \\
\hline 12 & Section $16300-4,2.7 .2$. Correct for actual transformer to be supplied. & & $\begin{array}{l}\text { The specification is correct for the transformer selected based on the } \\
\text { service sizing calculation submitted. The specification section will be } \\
\text { revised if directed to use a different transformer or revised load } \\
\text { calculations result in the selection of a different transformer. Utilizing } \\
\text { an existing dry type transformer is a change in scope from previous } \\
\text { direction and must be authorized by Jeff Filip and Kirk Ellard. Meier } \\
\text { Associates is awaiting written direction from Kirk Ellard, Merrick } \\
\text { Engineers. }\end{array}$ & OK \\
\hline 13 & Section 16120-1, shall be UL listed and labeled. & & Agreed, will incorporate as suggested. & OK \\
\hline 14 & Section $16450-1,1,2.1$. Change to NFPA $70-1996$. & & Agreed, will incorporate as suggested. & OK \\
\hline
\end{tabular}




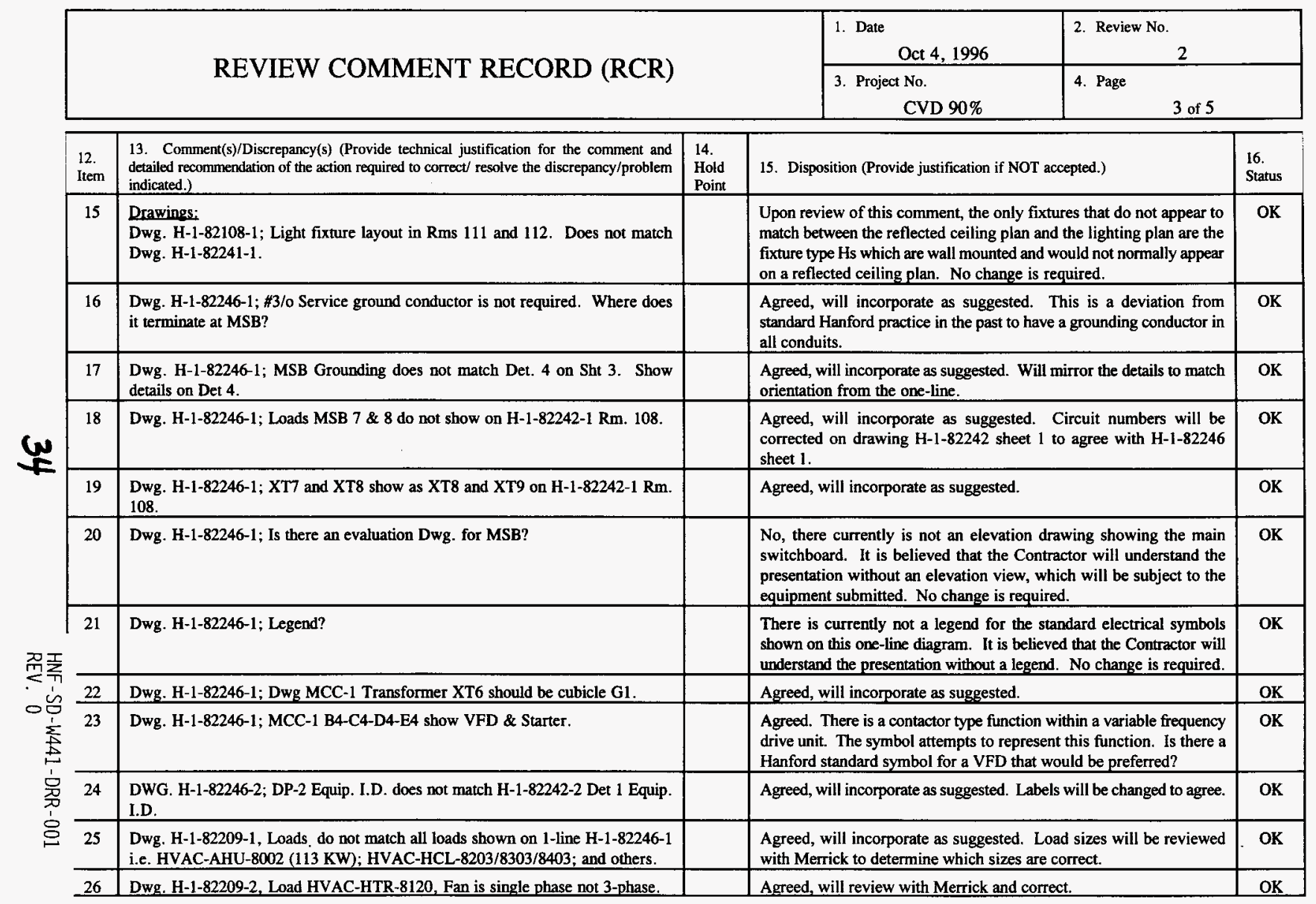

$.6400-090.1(03 / 92)$ WEF011 


\begin{tabular}{|c|c|c|}
\hline \multirow{2}{*}{ REVIEW COMMENT RECORD (RCR) } & $\begin{array}{l}\text { 1. Date } \\
\text { Oct 4, } 1996\end{array}$ & $\begin{array}{r}\text { 2. Review No. } \\
\\
2\end{array}$ \\
\hline & $\begin{array}{l}\text { 3. Project No. } \\
\text { CVD } 90 \%\end{array}$ & 4. Page \\
\hline
\end{tabular}

\begin{tabular}{|c|c|c|c|c|}
\hline $\begin{array}{l}12 . \\
\text { Item }\end{array}$ & $\begin{array}{l}\text { 13. Comment(s)/Discrepancy(s) (Provide technical justification for the comment and } \\
\text { detailed recommendation of the action required to correct/ resolve the discrepancy/problem } \\
\text { indicated.) }\end{array}$ & $\begin{array}{l}14 . \\
\text { Hold } \\
\text { Point }\end{array}$ & 15. Disposition (Provide justification if NOT accepted.) & $\begin{array}{l}16 . \\
\text { Status }\end{array}$ \\
\hline 27 & $\begin{array}{l}\text { H-1-82242-2; Det } 1 \text { Enlarged Bay Equipment Plan, do all the electrical enclosures } \\
\text { shown have NEC Vertical clearance? }\end{array}$ & & $\begin{array}{l}\text { Yes. All equipment shown is believed to be in compliance with the } \\
\text { NEC Article } 384-4(1) \text { and } 110-16(e) \text {. Please clarify concern if there is } \\
\text { specific equipment believed to be in violation. }\end{array}$ & OK \\
\hline 28 & H-1-82242-3; Det A, Remove "Tie-Breakers" Text from vertical section Al. & & Agreed, will incorporate as suggested. & OK \\
\hline 29 & $\begin{array}{l}\text { H-1-82246-1; Not all loads shown on MCC-1 single line are listed on Mech. or } \\
\text { HVAC schedules? }\end{array}$ & & Agreed, will review with Merrick and correct. & OK \\
\hline 30 & $\begin{array}{l}\text { H-1-82246-2; Does 2-ton crane (as shown on Dist. PNL 2-5) have only one } \\
\text { motor? }\end{array}$ & & Agreed, will review with Structural and correct. & OK \\
\hline 31 & H-1-82246-2; Dist. PNL 2-5, show overhead door. & & Agreed, will incorporate as suggested. & OK \\
\hline 32 & $\begin{array}{l}\text { H-1-82246-2; Is process boom controller a single contactor for two motors as } \\
\text { shown on Dist. PNL 2-5? }\end{array}$ & & $\begin{array}{l}\text { Boom deleted. Hood lift to provide either interlock or physical barrier } \\
\text { to prevent accidental hood movement during operation. }\end{array}$ & OK \\
\hline 33 & $\begin{array}{l}\text { H-1-82247-1/2/3; Loads are shown on SPARE circuit breakers, revise circuit and } \\
\text { panel loads to final values. }\end{array}$ & & $\begin{array}{l}\text { All spare circuit breakers show the NEC maximum allowed load for } \\
\text { that size branch circuit breaker. In this way, the design criteria for } \\
\text { spares and future capacity is designed into all panel sizes, transformer } \\
\text { sizes, wire, and conduit throughout the facility power distribution } \\
\text { system. Circuit and panel load values shown are the maximum final } \\
\text { value for the amount and sizes of spares shown. }\end{array}$ & OK \\
\hline 34 & $\begin{array}{l}\text { H-1-82280-1; Conduit and wire schedule is not complete, several circuits do not } \\
\text { extend to the load, i.e. P201, P202, P203; typical for distribution PNL 2-5. }\end{array}$ & & $\begin{array}{l}\text { All conduit and wiring shown on the wire run list is intended to reflect } \\
\text { facility wiring. Conduit and wiring supplied as part of the equipment } \\
\text { by the vendor is not shown. All devices included in the comment as } \\
\text { examples are vendor provided devices, crane controller, door operator, } \\
\text { and HVAC fan disconnect. No change is required. }\end{array}$ & OK \\
\hline 35 & H-1-82280; 600 Series conduits are not shown. & & $\begin{array}{l}\text { Currently } 600 \text { series conduits are not used as they were reserved for the } \\
\text { sixth bay which was deleted. May use for facility service conduits not } \\
\text { previously listed. Will clarify on conduit schedules. }\end{array}$ & OK \\
\hline 36 & $\begin{array}{l}\text { H-1-82246, Sh 1; zn E8: Grounding electrode conductor needs to be identified and } \\
\text { sized per } 250-94 \text {. See comment } \# 17 \text {. }\end{array}$ & & $\begin{array}{l}\text { The grounding electrode conductor is identified in Detail } 4 \text { on } \mathrm{H}-1 \text { - } \\
82246 \text { sheet } 3 \text { and sized on } \mathrm{H}-1-82246 \text { sheet } 1 \text {. As indicated in } \\
\text { response to comment } 17 \text { we will clarify the intent of Detail } 4 \text {. }\end{array}$ & OK \\
\hline 37 & $\begin{array}{l}\mathrm{H}-1-82246, \mathrm{Sh} 3, \mathrm{Zn} \text { D2-F2: Details } 4 \text { \& } 5 \text { identify grounding electrode conductor } \\
\text { and size per } 250-94 \text {. }\end{array}$ & & Not accepted. See note on detail for conductor and size. & OK \\
\hline
\end{tabular}




\begin{tabular}{|c|c|c|}
\hline \multirow{2}{*}{ REVIEW COMMENT RECORD (RCR) } & $\begin{array}{l}\text { 1. Date } \\
\text { Oct 4, } 1996\end{array}$ & $\begin{array}{l}\text { 2. Review No. } \\
2 \\
\end{array}$ \\
\hline & $\begin{array}{l}\text { 3. Project No. } \\
\text { CVD 90\% }\end{array}$ & 4. Page \\
\hline
\end{tabular}

\begin{tabular}{|c|c|c|c|c|}
\hline $\begin{array}{l}12 . \\
\text { Item }\end{array}$ & $\begin{array}{l}\text { 13. Comment(s)/Discrepancy(s) (Provide technical justification for the comment and } \\
\text { detailed recommendation of the action required to correct/ resolve the discrepancy/problem } \\
\text { indicated.) }\end{array}$ & $\begin{array}{l}14 . \\
\text { Hold } \\
\text { Point }\end{array}$ & 15. Disposition (Provide justification if NOT accepted.) & $\begin{array}{l}16 . \\
\text { Status }\end{array}$ \\
\hline 38 & $\begin{array}{l}\text { H-1-82246, Sh 1, Zn E5: Need grounding detail for isolation transformer labeled } \\
\text { XT8. }\end{array}$ & & Agreed, will incorporate as suggested. Will refer to Detail 5. & OK \\
\hline 39 & $\begin{array}{l}\text { H-1-82246, General: Transformer Secondary conductor raceways do not require } \\
\text { equipment grounding conductor in addition to grounded (neutral) conductor. }\end{array}$ & & $\begin{array}{l}\text { Agreed, will incorporate as suggested. This is a deviation from } \\
\text { standard Hanford practice in the past to have a grounding conductor in } \\
\text { all conduits. }\end{array}$ & OK \\
\hline 40 & $\begin{array}{l}\text { H-1-82246-1/2/3 Conductor and Raceway sizes, C.B. Sizes, etc. cannot be } \\
\text { verified until loads are better defined. Ref. comment } \$ 25 \text { and } 33 \text {. }\end{array}$ & & $\begin{array}{l}\text { Reference responses to comments } 25 \text { and } 33 \text {. Other than a few } \\
\text { exceptions where Merrick-selected equipment may have changed } \\
\text { without notifying Meier until the } 90 \% \text { set was issued, all conductor and } \\
\text { raceway sizes, circuit breaker sizes, etc. should be verifiable for loads } \\
\text { shown. Please clarify specific loads that require better definition. }\end{array}$ & OK \\
\hline 41 & $\begin{array}{l}\text { General: The loads in this design are not well defined, if you look at the panel } \\
\text { schedules there are many load values assigned to spare breakers. Also, if one } \\
\text { looks at a feeder breaker that feeds a panel, the two loads do not match. This } \\
\text { makes it difficult to calculate branch and feeder circuits and panel sizes and } \\
\text { complete the design accurately. In the positive regard, the significant (larger) } \\
\text { loads appear to be fairly well defined. }\end{array}$ & & $\begin{array}{l}\text { See responses to specific issues raised above. Regarding spare breaker } \\
\text { loads, see response to comment } 33 \text {. Feeder breaker loads shown for } \\
\text { transformers are based on transformer rating rather than connected load. } \\
\text { This is to assure that all breakers, wiring, and conduits are sized to } \\
\text { handle the maximum load allowed for the transformer shown. Will } \\
\text { incorporate as suggested after contacting reviewer for further } \\
\text { clarification of desired changes. }\end{array}$ & OK \\
\hline
\end{tabular}




\section{REVIEW COMMENT RECORD (RCR)}

\begin{tabular}{|l|l|}
\hline $\begin{array}{l}\text { 1. Date } \\
10 / 04 / 96\end{array}$ & 2. Review No. \\
\hline $\begin{array}{c}\text { 3. Project No. } \\
\text { W-441-C1 }\end{array}$ & 4. Page $\quad 1$ of 5 \\
\hline
\end{tabular}

\begin{tabular}{|l|l|l|l|l|}
\hline 5. Document Number(s)/Title(s) & $\begin{array}{l}\text { 6. Program/Project/ } \\
\text { Building Number } \\
\text { SNFP/CVDF/142K }\end{array}$ & 7. Reviewer & 8. Organization/Group \\
$\begin{array}{l}\text { Cold Vacuum Drying Facility 90\% Design } \\
\text { Review }\end{array}$ & Whitney & Dyncorp/Electrical Utilities & 2101M/373-3806 \\
\hline
\end{tabular}

17. Comment Submittal Approval:

Organization Manager (Optional)
10. Agreement with indicated comment disposition(s)

$\frac{3.25-47}{\text { Date }}$

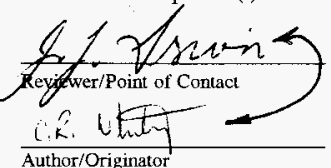

11. CLOSED

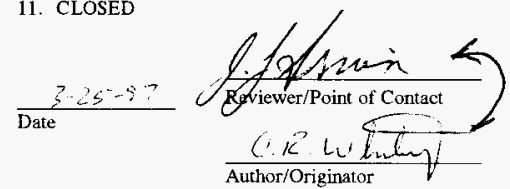

\begin{tabular}{|c|c|c|c|c|}
\hline $\begin{array}{l}12 . \\
\text { Item }\end{array}$ & $\begin{array}{l}\text { 13. Comment(s)/Discrepancy(s) (Provide technical justification for the comment and } \\
\text { detailed recommendation of the action required to correct/ resolve the discrepancy/problem } \\
\text { indicated.) }\end{array}$ & $\begin{array}{l}14 . \\
\text { Hold } \\
\text { Point }\end{array}$ & 15. Disposition (Provide justification if NOT accepted.) & $\begin{array}{l}16 . \\
\text { Starus }\end{array}$ \\
\hline 1 & $\begin{array}{l}\text { H-1-82242: Install ground ring around transformer pad with grounded bollards at } \\
\text { corners. Ground ring is to be tied to transformer ground coming from concrete } \\
\text { encased duct bank. Concrete pad around vault is not necessary }\end{array}$ & & $\begin{array}{l}\text { Agreed, will incorporate ground ring and bollards as suggested. } \\
\text { Concrete pad will remain as designed. }\end{array}$ & OK \\
\hline 2 & $\begin{array}{l}\text { H-1-82280: High voltage cable or conduits aren't identified on conduit or wire run } \\
\text { schedule. Cable should be } 15 \mathrm{kV} \text { EPR } 3 \text { - } \$ 2 \mathrm{CU} \text {. Add one spare primary conduit } \\
\text { from } 13.8 \mathrm{kV} \text { riser to outside transformer vault and one } 3 / 4 \text { inch conduit from riser } \\
\text { pole to transformer vault and continue } 3 / 4 \text { inch conduit from transformer vault to } \\
\text { main switchboard room. FDAS panel. Add one } 18 \text { AWG shielded twisted pair } \\
\text { from the riser pole (coil } 10 \text { feet at base of pole) routed back to FDAS panel in } \\
\text { switchboard room. Coil } 10 \text { feet of the } \# 18 \text { AWG conductors at base of riser pole } \\
\text { and } 2 \text { feet in FDAS panel. See related item } \# 7 \text {. }\end{array}$ & & 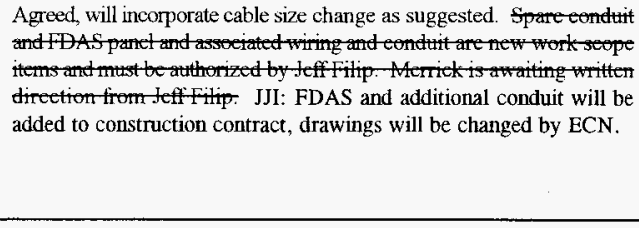 & OK \\
\hline 3 & $\begin{array}{l}\text { H-1-82095, sht 1: Sag and tensions are extreme design conditions and don't give } \\
\text { the contractor sag dimensions for anticipated installation ternperatures. The } \\
\text { conductor sags should be calculated for an initial sag of } 15 \% \text { of the rated breaking } \\
\text { strength. }\end{array}$ & & 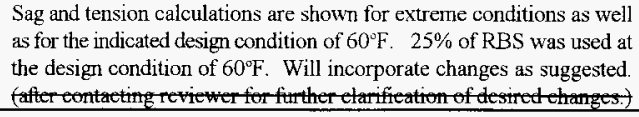 & OK \\
\hline 4 & $\begin{array}{l}\text { H-1-82095, sht 2: (Typical) Hot line clamps, identified as part \#15, must be used } \\
\text { with hot lime type stir-ups. The material list on H-1-82095, sht } 1 \text { must reflect the } \\
\text { hot line stir-up as well as the hot line clamp. }\end{array}$ & & $\begin{array}{l}\text { Agreed, will incorporate new part number and revise existing part } \\
\text { number } 15 \text { to reflect aluminum bail clamps and aluminum to copper hot } \\
\text { line clamps as suggested. }\end{array}$ & OK \\
\hline 5 & $\begin{array}{l}\text { H-1-82095, sht } 2: \text { Details } 2 \& 3 \text { jumper connections should be press on } \\
\text { comectors rather than hot line clamps. }\end{array}$ & & Agreed. Will incorporate compression connectors as suggested. & OK \\
\hline
\end{tabular}




\section{REVIEW COMMENT RECORD (RCR)}

\begin{tabular}{|l|l|}
\hline $\begin{array}{l}\text { 1. Date } 10 / 04 / 96 \\
\text { 3. Project No. } \\
\text { W-441-C1 }\end{array}$ & 2. Revicw No. \\
\hline $\begin{array}{c}\text { 4. Page } \\
2 \text { of } 5\end{array}$ \\
\hline
\end{tabular}

12. 13. Comment(s)/Discrepancy(s) (Provide technical justification for the comment and

Item ailed recommendation of the action required to correct/ resolve the discrepancy/problem indicated.)

6 H-1-82095, sht 3: (Detail 4) Jumpers for riser connections should be CU with AL-CU connectors. Remove Note 1 for this sheet. Change "3 No.6 AWG inch $C^{\prime \prime}$ to "3 \#2, 15kV EPR - 4 inch conduit". Change "split-bolt connector, typical" to "permanent compression connector, typical". Remove requirement for heat shrink type cable terminator and replace with "Exterior Style $15 \mathrm{kV}$ cable terminator".

7 H-1-82095, sht 3: (Detail 4) Revise riser detail to incorporate primary metering between overhead circuit and cutouts. See attached marked up drawing for an example. Riser conduit to be rigid metal conduit and underground conduit to be concrete encased with an encased grounding conductor. Concrete encasement to have one capped spare 4 inch conduit and one $3 / 4$ inch conduit for metering. The $3 / 4$ inch conduit, containing one \#18 twisted pair, is to be routed from pole GS-3 through the transformer vault and continue on to the electrical room where it is to be connected to a Field Data Acquisition System (FDAS). The FDAS will be supplied by Electrical Utilities upon request. Add a note for a $120 \mathrm{Vac}$ circuit to be routed to the FDAS along with a phone jack. The total FDAS load is tess than 240VA and will occupy a wall space of about 2.5 feet by 3 feet with a depth of 8 inches. Primary metering will consist of 1-ABB Alpha A1R meter, 1-Circle AW meter socket \#12148, 1-Superior test switch \#1040-F, 2-15kV CT's (30:5 GE type JCK-5 model \#755X52G5), 2-15kV VT's (14400:120 with 1A fuses GE type JVW-110 model $\# 765 \times 31$ G14). See related item $\# 2$.

8 H-1-82101: Install bollards around electrical transformer. Concrete pad around electrical transformer is not necessary. in 9 H-1.82246: Delete "NEW" from 1500kVA transformer description. Add note
identifying 1500kVA dry type transformer is available and located on the west side of $165 \mathrm{KW}$. Contractor is to interface transformer to vault lid and openings. Add note designating utility/facility interface as the primary of the transformer if a dry type transformer is used or to the secondary bushings of the transformer if an oil type transformer is
transformer is used.

\begin{tabular}{|c|c|c|}
\hline $\begin{array}{l}14 . \\
\text { Hold } \\
\text { Point }\end{array}$ & 15. Disposition (Provide justification if NOT accepted.) & $\begin{array}{l}16 . \\
\text { Status }\end{array}$ \\
\hline & Agreed. Will incorporate all changes as suggested. & OK \\
\hline & 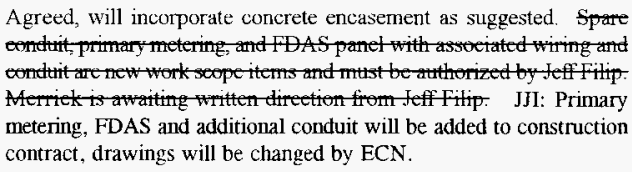 & OK \\
\hline & 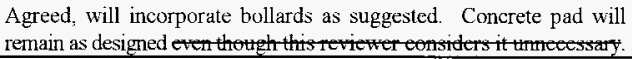 & OK \\
\hline & 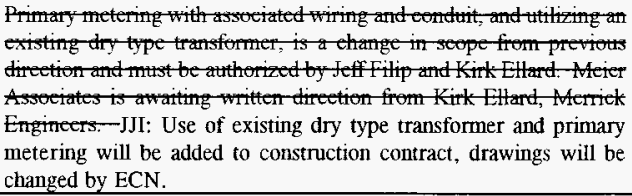 & OK \\
\hline & $\begin{array}{l}\text { Agreed, will incorporate as suggested after eontating reviewer for } \\
\text { furtherctarifieation of tesirethanges. }\end{array}$ & OK \\
\hline
\end{tabular}




\section{REVIEW COMMENT RECORD (RCR)}

\begin{tabular}{|c|l|}
\hline $\begin{array}{l}\text { 1. Date } \\
10 / 04 / 96\end{array}$ & 2. Review No. \\
\hline $\begin{array}{c}\text { 3. Project No. } \\
\text { W-441-Cl }\end{array}$ & 4. Page \\
\hline
\end{tabular}

\begin{tabular}{|c|c|c|c|c|}
\hline $\begin{array}{l}12 . \\
\text { Item }\end{array}$ & $\begin{array}{l}\text { 13. Comment(s)/Discrepancy(s) (Provide technical justification for the comment and } \\
\text { detailed recommendation of the action required to correct/ resolve the discrepancy/problem } \\
\text { indicated.) }\end{array}$ & $\begin{array}{l}14 . \\
\text { Hold } \\
\text { Point }\end{array}$ & 15. Disposition (Provide justification if NOT accepted.) & $\begin{array}{l}16 . \\
\text { Status }\end{array}$ \\
\hline 11 & $\begin{array}{l}\text { Electrical Calculations - Service Sizing Calculations } \\
\text { Loads do not appear realistic, however, if a } 1500 \mathrm{kVA} \text { transformer is to be used } \\
\text { for XTA then primary metering with FDAS will be necessary. See note } 7 \text {. }\end{array}$ & & $\begin{array}{l}\text { The electrical service sizing calculations are based on the } \\
\text { assumption that all loads shown are continuous, meaning, per } \\
\text { the NEC the maximum current is expected to continue for three } \\
\text { hours or more. Will revise calculations based on input from } \\
\text { Merrick regarding operating durations that would reflect as } \\
\text { non-continuous. Other than a few exceptions where Merrick- } \\
\text { selected equipment may have changed without notifying Meier } \\
\text { until the } 90 \% \text { set was issued, all conductor and raceway sizes, } \\
\text { circuit breaker sizes, etc., should be verifiable for loads shown. } \\
\text { Ptease etarify specific loats that require better definition to } \\
\text { appear more reatistic. Primary metering with assuciated wiring } \\
\text { anterndur, and utitizing an existing dry type transformer, is } \\
\text { a etrange in seope from previous direction and must be } \\
\text { authorized by Jeff Fitip and Kirk Ellard. Meier Associates is } \\
\text { awaiting written direetion from Kirk Eltard, Merrick } \\
\text { Engineers. JJI: FDAS and primary metering will be added to } \\
\text { construction contract, drawings/specifications will be changed by } \\
\text { ECN. }\end{array}$ & $\mathrm{OK}$ \\
\hline 12 & $\begin{array}{l}\text { Construction Specification - Section } 1040-2,1.3 \text { : } \\
\text { Change requirement for contractor to request Construction Management } \\
14 \text { days prior to starting work electrical lines and utility poles. }\end{array}$ & & Agreed, to be controlled by CVDF Construction Management. & OK \\
\hline 13 & $\begin{array}{l}\text { Construction Specification - Section 1040-3, 1.8: } \\
\text { Add statement to System Outages and Ties-Ins that final connection which will } \\
\text { energize new electrical service from utility system will be performed by the site } \\
\text { Electrical Utilities Department. All construction and material necessary for } \\
\text { energizing of electrical service must be completed prior to final connection by the } \\
\text { site Electrical Utilities Department. }\end{array}$ & & Agreed, to be controlled by CVDF Construction Management. & OK \\
\hline 14 & $\begin{array}{l}\text { Construction Specification - Section } 1065-2,1.2 .7 \text { : } \\
\text { Change requirement from } 5 \text { days to } 14 \text { days prior to starting work. }\end{array}$ & & Agreed, to be controlled by CVDF Construction Management. & OK \\
\hline
\end{tabular}




\section{REVIEW COMMENT RECORD (RCR)}

\begin{tabular}{|c|l|}
\hline $\begin{array}{l}\text { 1. Date } \\
10 / 04 / 96\end{array}$ & 2. Review No. \\
\hline $\begin{array}{c}\text { 3. Project No. } \\
\text { W-441-Cl }\end{array}$ & 4. Page \\
\hline
\end{tabular}

\begin{tabular}{|c|c|c|c|c|}
\hline $\begin{array}{l}12 . \\
\text { Item }\end{array}$ & $\begin{array}{l}\text { 13. Comment(s)/Discrepancy(s) (Provide technical justification for the comment and } \\
\text { detailed recommendation of the action required to correct/ reselve the discrepancy/problem } \\
\text { indicated.) }\end{array}$ & $\begin{array}{l}14 . \\
\text { Hold } \\
\text { Point }\end{array}$ & 15. Disposition (Provide justification if NOT accepted.) & $\begin{array}{l}16 . \\
\text { Status }\end{array}$ \\
\hline 15 & $\begin{array}{l}\text { Construction Specification - Section } 1315-5,3.3 \text { : } \\
\text { Add statement requiring a two week schedule (14 day notification) for coordination } \\
\text { with the site Electrical Utilities Department. }\end{array}$ & & Agreed, to be controlled by CVDF Construction Management. & $\mathrm{OK}$ \\
\hline 16 & $\begin{array}{l}\text { Construction Specification - Section } 1500-2,1.5 .1 \text { : } \\
\text { Construction Management to coordinate with the site Electrical Utilities } \\
\text { Department } 14 \text { days prior to needing temporary power connected. Construction } \\
\text { Management is responsible for submitting an Electrical Service Request to the site } \\
\text { Electrical Utilities Department. Final connection/tie-in to the electrical distribution } \\
\text { system is to be performed by the site Electrical Utilities Department. See also } \\
\text { item 13. Temporary electrical metering will have to be coordinated through the } \\
\text { site Electrical Utilities Department as well. }\end{array}$ & & Agreed, to be controlled by CVDF Construction Management. & OK \\
\hline 17 & $\begin{array}{l}\text { Construction Specification - Section } 2700-5,3.4 .3 \text { : } \\
\text { Change notification for utility tie ins from } 7 \text { days to } 14 \text { days. See items } 12,14-16 \text {. }\end{array}$ & & Agreed, to be controlled by CVDF Construction Management. & OK \\
\hline 18 & $\begin{array}{l}\text { Construction Specification - Section 16000-1, 1.2: } \\
\text { Add reference to ANSI C2 National Electrical Safety Code (NESC) } 1997 .\end{array}$ & & Agreed. Will incorporate as suggested. & OK \\
\hline 19 & $\begin{array}{l}\text { Construction Specification - Section 16300-1, 1.2.1.1: } \\
\text { Change ANSI C2-1993 reference to ANSI C2(NESC-1997). }\end{array}$ & & Agreed. Will incorporate as suggested. & OK \\
\hline 20 & $\begin{array}{l}\text { Construction Specification - Section } 16300-3,2.4 \text { : } \\
\text { Add standard for PVC conduit to } 2.4 .1 \text { and verbiage to } 2.4 \text { requiring underground } \\
\text { primary ( } 13.8 \mathrm{kV}) \text { conduit to be encased in } 3 \text { inches of concrete regardless of type } \\
\text { of conduit used. }\end{array}$ & & Agreed. Will incorporate as suggested. & $\mathrm{OK}$ \\
\hline 22 & $\begin{array}{l}\text { Construction Specification - Section } 16300-3,2.5 \text { : } \\
\text { Add verbiage to cable requirements in } 2.5 .1 \text { for insulation to be Ethylene- } \\
\text { Propylene-Rubber. Delete "ungrounded" and add "tape-shield". }\end{array}$ & & Agreed. Will incorporate as suggested. & OK \\
\hline $\begin{array}{l}\text { OK } \\
23 \\
\text { OK }\end{array}$ & $\begin{array}{l}\text { Construction Specification - Section } 16300-4,2.6 \text { : } \\
\text { Add reference or verbiage for high voltage termination kits and load break elbows. }\end{array}$ & & Agreed. Will incorporate as suggested. & OK \\
\hline
\end{tabular}




\begin{tabular}{|c|l|l|}
\hline \multirow{2}{*}{ REVIEW COMMENT RECORD (RCR) } & 1. Date & $10 / 04 / 96$ \\
\cline { 2 - 3 } & $\begin{array}{c}\text { 3. Project No. } \\
\text { W-441-Cliew No. }\end{array}$ & 4. Page \\
\hline
\end{tabular}

\begin{tabular}{|c|c|c|c|c|}
\hline $\begin{array}{l}12 . \\
\text { Item }\end{array}$ & $\begin{array}{l}\text { 13. Comment(s)/Discrepancy(s) (Provide technical justification for the comment and } \\
\text { detailed recommendation of the action required to correct/ resolve the discrepancy/problem } \\
\text { indicated.) }\end{array}$ & $\begin{array}{l}14 . \\
\text { Hold } \\
\text { Point }\end{array}$ & 15. Disposition (Provide justification if NOT accepted.) & $\begin{array}{l}16 . \\
\text { Status }\end{array}$ \\
\hline 24 & $\begin{array}{l}\text { Construction Specification - Section } 16300-4,2.7 .2 .1 \text { : } \\
\text { Add requirement for a two position (on-oft) oil immersed, ganged, primary switch } \\
\text { connected so switching disconnects transformer coil from loop bushings. Change } \\
\text { accessory "A": bayonet fuse requirement from "Kearney DEWL cat no. } 124080- \\
05^{n} \text { to "RTE bayonet fuses cat. no. } 4000353 \mathrm{C} 16 \text { ". Change accessory "B": back } \\
\text { up, current limiting fuse from "Kearney cat. no. } 150608-40 \text { " to "two parallel RTE } \\
\text { ELSP Current Limiting Fuses cat. no. } 3544100 \mathrm{M} 1 \mathrm{M} \text { ". Change accessory "H": } \\
\text { from "insulated grounded bushing caps" to "grounded standoff bushings and } \\
\text { insulating caps". }\end{array}$ & & 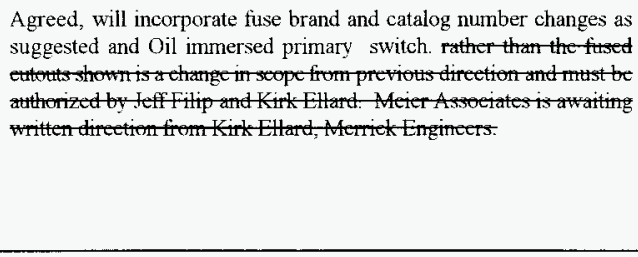 & OK \\
\hline 25 & $\begin{array}{l}\text { Construction Specification - Section } 16300-5,3.2 \text { : } \\
\text { Add verbiage to provide one loop of primary cable in transformer vault. }\end{array}$ & & Agreed. Will incorporate as suggested. & OK \\
\hline 26 & $\begin{array}{l}\text { Construction Specification - Section 16450-1 1.2.1: } \\
\text { Add ANSI C2(NESC-1997) to grounding codes and standards. }\end{array}$ & & Agreed. Will incorporate as suggested. & $\mathrm{OK}$ \\
\hline
\end{tabular}




\section{REVIEW COMMENT RECORD (RCR)}

\begin{tabular}{|c|l|}
\hline $\begin{array}{c}\text { 1. Date } \\
\text { October 2, } 1996\end{array}$ & $\begin{array}{c}\text { 2. Review No. } \\
\text { (W44190\%.RCR) }\end{array}$ \\
\hline $\begin{array}{c}\text { 3. Project No. } \\
\text { W441 }\end{array}$ & 4. Page 7 \\
\hline
\end{tabular}

5. Document Number(s)/Title(s)

Cold Vacuum Drying Facility - 90\% Design Review

17. Comment Submittal Approval:

Organization Manager (Optional)

\begin{tabular}{l|l}
$\begin{array}{l}\text { 6. Program/Project/ } \\
\text { Building Number } \\
\text { SNF/W441/142K }\end{array}$ & 7. Reviewer \\
& W. A. Frier \\
\hline
\end{tabular}

10. Agreement with indicared comment dispgsition(s)

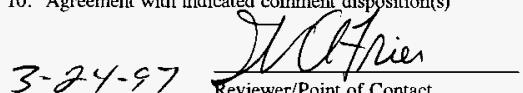

$\frac{3-24-57}{\text { Date }}$

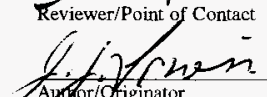

8. Organization/Group
K Basins Cognizant
Engineering

9. Location/Phone

M0402K/373-3946

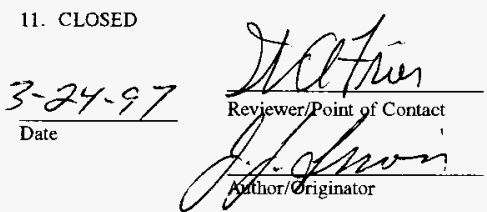

\begin{tabular}{|c|c|c|c|c|}
\hline $\begin{array}{l}12 . \\
\text { Itemn }\end{array}$ & $\begin{array}{l}\text { 13. Comment(s)/Discrepancy(s) (Provide technical justification for the comment and } \\
\text { detailed recommendation of the action required to correct/ resolve the } \\
\text { discrepancy/problem indicated.) }\end{array}$ & $\begin{array}{l}14 . \\
\text { Hold } \\
\text { Point }\end{array}$ & 15. Disposition (Provide justification if NOT accepted.) & $\begin{array}{l}16 . \\
\text { Status }\end{array}$ \\
\hline 1. & $\begin{array}{l}\text { General comment--Decouple office portion from truck bays so that truck } \\
\text { bays and balance of facility can be decommissioned ahead of the office } \\
\text { portion. (Good office space maybe of value during decommissioning). }\end{array}$ & & $\begin{array}{l}\text { Not acepted based on prior analysis and decision: } \\
\text { JJI: Process bays are decoupled structurally and have separate } \\
\text { HVAC systems. }\end{array}$ & $\mathrm{ClO}^{\circ}$ \\
\hline 2. & $\begin{array}{l}\text { H-1-82101-- (1) ZN C4--Add door number at south end of Rm } 116 \text {. } \\
\text { (2) Add door numbers to administrative office area, Room } 117 \text {, south } \\
\text { stair well. } \\
\text { (3) Why not number the Spare Bay number } 5 \text { and reverse the order and } \\
\text { start Bay } 1 \text { at the south end?? }\end{array}$ & & $\begin{array}{l}\text { (1) Door numbers are shown in one location on enlarged } \\
\text { plans. } \\
\text { (2) Door numbers are shown in one location on enlarged } \\
\text { plans. } \\
\text { (3) No numbering sequence was finalized during Conceptual } \\
\text { Design Phase. }\end{array}$ & \\
\hline 3. & H-1-82102--Specify foot print of crane travel. & & See Flag Note 6. & \\
\hline 4. & $\begin{array}{l}\text { H-1-82104-(1) Confirm that bridge crane and jib crane elevations are } \\
\text { correct. (2) Resolve bridge crane discrepancies, ie., underhung or top } \\
\text { running bridge crane. (preference is top running). }\end{array}$ & & $\begin{array}{l}\text { JJ: Elevations are correct, Top running crane specified (Spec. } \\
\text { Section } 14610 \text {. }\end{array}$ & \\
\hline 5. & $\begin{array}{l}\text { H-1-82105, Section C--(1) Add monorail elevation. } \\
\text { (2) Resolve discrepancy between Section C, H-1-82101 \& H-1-82106, } \\
\text { North Elevation. (Section C shows two doors, H-1-82101 shows no } \\
\text { doors \& H-1-82106 shows one door). }\end{array}$ & & $\begin{array}{l}\text { (1) Monorail elevation shall be shown on drawing H-1-82132. } \\
\text { (2) The designer cannot find the addressed discrepancy. }\end{array}$ & $\checkmark$ \\
\hline
\end{tabular}




\begin{tabular}{|l|l|l|}
\hline \multirow{2}{*}{ REVIEW COMMENT RECORD (RCR) } & $\begin{array}{l}\text { 1. Date Review No. } \\
\text { October 2, } 1996\end{array}$ \\
\cline { 2 - 3 } & 3. Project No. \\
W44190\%.RCR) & $\begin{array}{c}\text { 4. Page } \\
2 \text { of } 7\end{array}$ \\
\hline
\end{tabular}

\begin{tabular}{|c|c|c|c|c|}
\hline $\begin{array}{l}12 . \\
\text { Item }\end{array}$ & $\begin{array}{l}\text { 13. Comment(s)/Discrepancy(s) (Provide technical justification for the comment and } \\
\text { detailed recommendation of the action required to correct/ resolve the } \\
\text { discrepancy/problem indicated.) }\end{array}$ & $\begin{array}{l}14 . \\
\text { Hold } \\
\text { Point }\end{array}$ & 15. Disposition (Provide justification if NOT accepted.) & $\begin{array}{l}16 . \\
\text { Status }\end{array}$ \\
\hline 6. & $\begin{array}{l}\text { H-1-82110--(1) Add access ladders to roof. (No provisions are provided } \\
\text { for accessing roof to perform maintenance or warranty inspections). (2) } \\
\text { Add metal member to roof at all levels strategically placed so that } \\
\text { workers can attach fall protection for maintenance. (Difficult to repair } \\
\text { flashings at roof edges). }\end{array}$ & & No permanent roof access is to be provided. & $\operatorname{ch}{ }^{2}{ }^{2}$ \\
\hline 7. & $\begin{array}{l}\text { H-1-82113, (1) Details } 11 \& 13 \text {--Incomplete details. (Structure needs to } \\
\text { be added between rake flashing trim and top of concrete wall). (2) } \\
\text { Detail 7--Is vapor barrier required below the rigid insulation over the } \\
\text { process bays? How is rigid insulation attached to steel plate? Why so } \\
\text { much insulation for a facility with limited life time? (It seems like } \\
\text { waivers to energy conservation code are warranted?) }\end{array}$ & & All roof details shall be finalized with roof design. & \\
\hline 8. & $\begin{array}{l}\text { H-1-82114, Detail 1--Provide dimensions for W18 Runway Beam } \\
\text { location. (eg., "X" inches from column centerline). }\end{array}$ & & $\begin{array}{l}\text { No. This type of dimension shall be indicated on structural } \\
\text { plans. }\end{array}$ & \\
\hline 9. & $\begin{array}{l}\text { H-1-82114, Section 9--Suggest retain seismic hold down capability for } \\
\text { MCO trailers. }\end{array}$ & & Section 9 does not exist on sheet. & \\
\hline 10. & $\begin{array}{l}\text { H-1-82115, Detail 2--Clarify note. (Do not understand "Fill in } \\
\text { Recesses. . .") }\end{array}$ & & Agreed. & \\
\hline 11. & $\begin{array}{l}\text { H-1-82364, Detail F--(1) Revise terminology to "Pedestal Jib Crane } \\
\text { Beam." (DOE-RL-92-36 references the crane as a "Pedestal Jib Crane" } \\
\text { not a monorail). (2) Why two details? (3) Add beam elevation. (4) } \\
\text { Why are channels and pipe attached to monorail beam web? }\end{array}$ & & Jib boom is no longer needed and has been removed. & \\
\hline 12. & $\begin{array}{l}\mathrm{H}-1-82117 \text { \& H-1-82104--Add provisions to access bridge cranes and jib } \\
\text { crane for maintenance. (OSHA requires yearly inspections and access is } \\
\text { required for inspections and maintenance). }\end{array}$ & & No. Access for inspections shall be made by portable means. & \\
\hline 13. & $\begin{array}{l}\text { W-441-C1, Section } 05100 \text {, Paragraph } 2.5 .1 \text {, last sentence--Suggest } \\
\text { fastening grating to structural metal with clips unless this is an ALARA } \\
\text { concern or unless welding takes less time than fastening with clips and } \\
\text { fasteners. (Facility life time is limited and ease of decommissioning). }\end{array}$ & & $\begin{array}{l}\text { Not accepted. Structural integrity is helped by welding and } \\
\text { QA is less time consuming. }\end{array}$ & V \\
\hline
\end{tabular}




\begin{tabular}{|l|l|l|}
\hline \multirow{2}{*}{ REVIEW COMMENT RECORD (RCR) } & $\begin{array}{l}\text { 1. Date } \\
\text { October 2, } 1996\end{array}$ \\
\cline { 2 - 4 } (Weview No. & $\begin{array}{c}1 \\
\text { 3. Project No. } \\
\text { W44190\%.RCR) }\end{array}$ \\
\hline
\end{tabular}

\begin{tabular}{|c|c|c|c|c|}
\hline $\begin{array}{l}12 . \\
\text { ltem }\end{array}$ & $\begin{array}{l}\text { 13. Comment(s)/Discrepancy(s) (Provide technical justification for the comment and } \\
\text { detailed recommendation of the action required to correct/ resolve the } \\
\text { discrepancy/problem indicated.) }\end{array}$ & $\begin{array}{l}14 . \\
\text { Hold } \\
\text { Point }\end{array}$ & 15. Disposition (Provide justification if NOT accepted.) & $\begin{array}{l}16 . \\
\text { Status }\end{array}$ \\
\hline 14. & $\begin{array}{l}\text { W-441-C1, Section } 08370 \text {, Paragraph 2.3.3--Confirm with operations } \\
\text { whether the controls for the door should be solely from the operator's } \\
\text { console. }\end{array}$ & & $\begin{array}{l}\text { Door is to be opened locally with permission from control } \\
\text { room. }\end{array}$ & $C .6$ \\
\hline 15 . & $\begin{array}{l}\text { W-441-C1, Section } 08700 \text {, Paragraph 2.3.1--Include security } \\
\text { requirements for exterior doors. (Liz Koster, 373-4464, is contact). }\end{array}$ & & Requirements have been requested but not provided. & \\
\hline 16. & $\begin{array}{l}\text { W-441-C1, Section 09800, Paragraph 2.1.3--Materials should be same } \\
\text { as CSB. }\end{array}$ & & RH Abbott: Section 2.1.3 was deleted. & \\
\hline 17. & 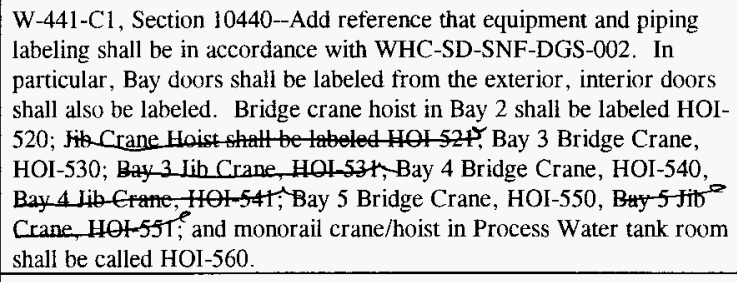 & & $\begin{array}{l}\text { RH Abbott :To be coordinated with Construction Manager. } \\
\text { JJI: WHC-SD-SNF-DGS-002 has beed added as a required } \\
\text { document for the CVDF: All labeling requiremnets will be } \\
\text { implemented. Verification item added to CM Action List. } \\
\text { Note; jib crane have been deleted. }\end{array}$ & \\
\hline 18. & $\begin{array}{l}\text { W-441-C1, Section 14610, Paragraph 1.2.1.4--Add: "ASME, 1995, } \\
\text { Rules for Construction of Overhead and Gantry Cranes (Top Running } \\
\text { Bridge, Multiple Girder) ASME NOG-1, American Society of } \\
\text { Mechanical Engineers, New York, New York." } \\
\text { ASME, 1994, Quality Assurance Program Requirements for Nuclear } \\
\text { Facilities, NQA-1, American Society of Mechanical Engineers, New } \\
\text { York, New York." }\end{array}$ & & $\begin{array}{l}\text { NOG not required. JJI: a structural analysis was performed } \\
\text { for a cask lid drop accident onto the MCO. The analysis did } \\
\text { not show a rupture of the MCO boundary, therefore a NOG-1 } \\
\text { crane is not required. }\end{array}$ & \\
\hline
\end{tabular}




\begin{tabular}{|l|l|l|}
\hline \multirow{2}{*}{ REVIEW COMMENT RECORD (RCR) } & $\begin{array}{l}\text { 1. Date } \\
\text { October 2, } 1996\end{array}$ & $\begin{array}{c}\text { 2. Review No. } \\
1 \\
\text { (W44190\%.RCR) }\end{array}$ \\
\cline { 2 - 4 } & $\begin{array}{l}\text { 3. Project No, } \\
\text { W441 }\end{array}$ & $\begin{array}{l}\text { 4. Page } \\
4 \text { of } 7\end{array}$ \\
\hline
\end{tabular}

\begin{tabular}{|c|l|l|l|}
\hline $\begin{array}{l}\text { 12. } \\
\text { Item }\end{array}$ & $\begin{array}{l}\text { 13. Comment(s)/Discrepancy(s) (Provide technical justification for the comment and } \\
\text { detailed recommendation of the action required to correct/ resolve the } \\
\text { discrepancy/problem indicated.) }\end{array}$ & $\begin{array}{l}\text { 14. } \\
\text { Hold } \\
\text { Point }\end{array}$ & $\begin{array}{l}\text { 15. Disposition (Provide justification if NOT accepted.) } \\
\text { Status }\end{array}$ \\
\hline 19. & $\begin{array}{l}\text { W-441-C1, Section 14610, (1) Add Paragraph 1.3.3.4 which reads } \\
\text { "Recommended spare parts list." (2) Paragraph 1.4.2--Revise service } \\
\text { from "D" to "B" light service in accordance with CMAA 70. (Service } \\
\text { B better describes operations). (3) Paragraph 2.1.1--Clarify whether } \\
\text { crane is top-running or underhung. (4) Paragraph 2.1.12 \& 2.1.14-- } \\
\text { Typo, "he" should be "the" }\end{array}$ & $\begin{array}{l}\text { 1) Accepted. } \\
\text { 2) Not accepted. } \\
\text { 3) Accepted. } \\
\text { 4) Accepted. }\end{array}$ \\
\hline
\end{tabular}




\section{REVIEW COMMENT RECORD (RCR)}

\begin{tabular}{|c|l|}
\hline $\begin{array}{c}\text { 1. Date } \\
\text { October 2,1996 }\end{array}$ & $\begin{array}{c}\text { 2. Review No. } \\
1 \\
\text { (W44190\%.RCR) }\end{array}$ \\
\hline $\begin{array}{c}\text { 3. Project No. } \\
\text { W441 }\end{array}$ & 4. Page 7 \\
\hline
\end{tabular}

12. 13. Comment(s)/Discrepancy(s) (Provide technical justification for the comment and

discrepancy/problem indicated.

20. W-441-C1, Section 14610, Section 2. Add the following:

2.1.X Provide seismic response spectra at crane height elevation for crane vendors. (Unless safety analysis supports otherwise, this should be a requirement).

2.1.X Crane Service is defined as Class $B$ in accordance with CMAA \#74. Trolley and hoist shall be Class $\mathrm{C}$ at the minimum.

2.1.X All requirements associated with fabrication and manufacturing of the trolley and hoist shall be in accordance with CMAA Specification $\# 70$, Specifications for Electric Overhead Traveling Cranes.

2.1.X The bridge crane shall operate in a $\mathrm{XX} \mathrm{mR} / \mathrm{hr}$ radiation field. The total dose over the life of the crane is not anticipated to exceed XX Rads.

2.1.X The bridge cranes shall make approximately 50-60 lifts per year per crane

2.1.X Analysis of dead loads and normal crane loads shall be in accordance with CMAA $\# 70$.

2.1.X Crane travel shall meet the dimensional envelope as defined in $\mathrm{H}-$ $1-82102$.

2.1.X The cranes shall be equipped with pendant control for hoist and travel motions. An emergency stop button independent of pendant control shall be provided.

\begin{tabular}{|c|c|c|}
\hline $\begin{array}{l}14 . \\
\text { Hold } \\
\text { Point }\end{array}$ & 15. Disposition (Provide justification if NOT accepted.) & $\begin{array}{l}16 . \\
\text { Status }\end{array}$ \\
\hline Yes & 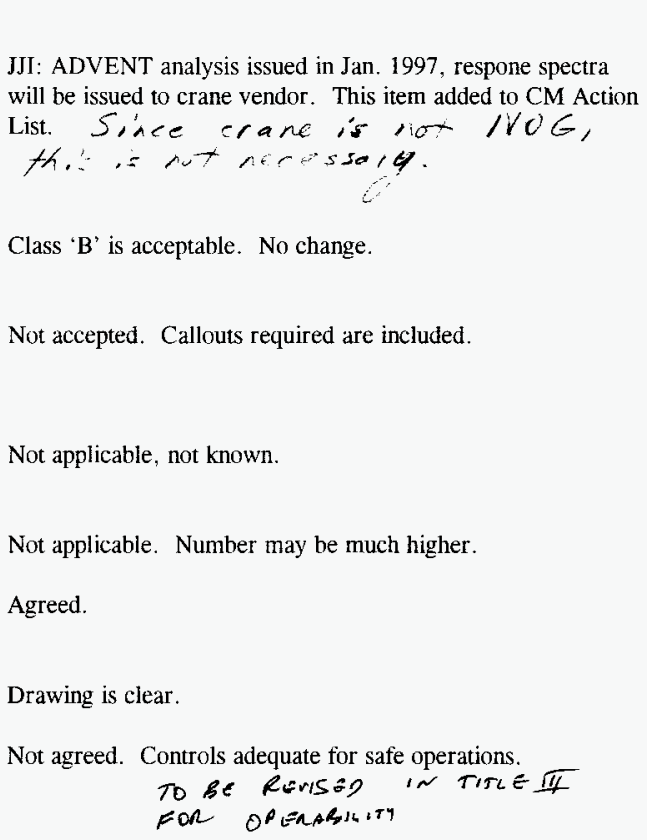 & $C \cos$ \\
\hline
\end{tabular}




\begin{tabular}{|l|l|l|}
\hline \multirow{2}{*}{ REVIEW COMMENT RECORD (RCR) } & $\begin{array}{l}\text { 1. Date } \\
\text { October 2, } 1996\end{array}$ \\
\cline { 2 - 3 } & $\begin{array}{c}\text { 3. Project No. } \\
\text { W441 }\end{array}$ & $\begin{array}{c}\text { 4. Page } \\
6 \text { of } 7\end{array}$ \\
\hline
\end{tabular}

\begin{tabular}{|c|c|c|c|c|}
\hline $\begin{array}{l}12 . \\
\text { Item }\end{array}$ & $\begin{array}{l}\text { 13. Comment(s)/Discrepancy(s) (Provide techrical justification for the comment and } \\
\text { detailed recommendation of the action required to correct/ resolve the } \\
\text { discrepancy/problem indicated.) }\end{array}$ & $\begin{array}{l}14 . \\
\text { Hold } \\
\text { Point }\end{array}$ & 15. Disposition (Provide justification if NOT accepted.) & $\begin{array}{l}16 . \\
\text { Status }\end{array}$ \\
\hline 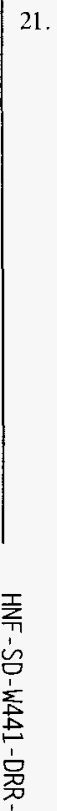 & $\begin{array}{l}\text { W-441-C1, Section } 14610 \text {, Section } 2 \text {. (continued) } \\
\text { 2.1.X The bridge, trolley, and hoists shall have positional accuracy of } \\
+1 / 4 \text { in. } \\
\text { 2.1.X All motors shall use } 460 \mathrm{~V} / 60 \mathrm{~Hz} / 3 \text { phase power. All electrical } \\
\text { materials and equipment shall be UL- or FM-tested with label attached, } \\
\text { and used only for the purpose intended. Where there are no UL- or } \\
\text { FM-listed products of the type, testing and certification by another } \\
\text { nationally recognized testing agency may be acceptable. } \\
\text { 2.1.X The Seller shall provide two controller options in their proposal, } \\
\text { for all motors. They are: } \\
\text { - Flux vector stepless controllers } \\
\text { - Variable frequency AC three step controllers } \\
\text { The Buyer will determine which controller to use for which motor, } \\
\text { prior, to contract placement. } \\
\text { 2.1.I1 Harmonic current limits of variable speed motors shall meet } \\
\text { IEEE } 519-192 \text {, Table } 10.3 \text { for a single customer. } \\
\text { Also, see attachment for list of submittals. } \\
\text { (Unless safety analysis says otherwise, comments } \# 20 \& \# 21 \text { shall be } \\
\text { included within the specification.) }\end{array}$ & & $\begin{array}{l}\text { Agreed. } \\
\text { Section } 16000 \text { calls out UL/FM listings. } 460 / 60 \mathrm{~Hz} / 30 \\
\text { included. } \\
\text { Not agreed. Not required or desireable for fixed price } \\
\text { contract. } \\
\text { Not accepted. This is vendor's responsibility. }\end{array}$ & $G$ \\
\hline
\end{tabular}




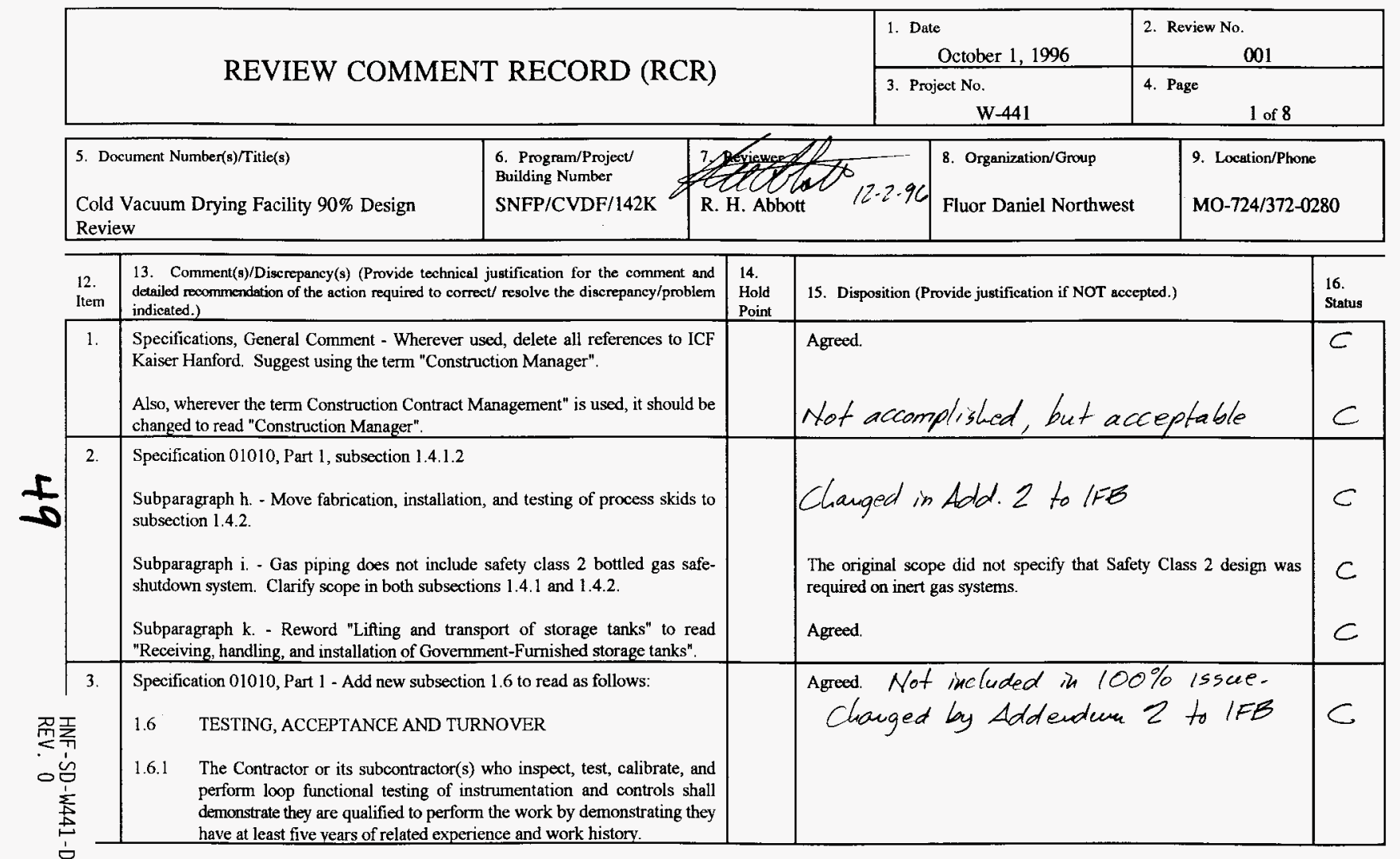




\begin{tabular}{|l|l|l|}
\hline \multirow{2}{*}{ REVIEW COMMENT RECORD (RCR) } & $\begin{array}{l}\text { 1. Date } \\
\text { October } 1,1996\end{array}$ \\
\cline { 2 - 3 } & $\begin{array}{c}\text { 3. Project No. } \\
\text { W-441 }\end{array}$ & $\begin{array}{c}\text { 4. Page } \\
\text { 2. }\end{array}$ \\
\hline
\end{tabular}

\begin{tabular}{|c|c|c|c|c|}
\hline $\begin{array}{l}12 . \\
\text { Item }\end{array}$ & $\begin{array}{l}\text { 13. Comment(s)/Discrepancy(s) (Provide technical justification for the comment and } \\
\text { detailed recommendation of the action required to correct/ resolve the discrepancy/problem } \\
\text { indicated.) }\end{array}$ & $\begin{array}{l}14 . \\
\text { Hold } \\
\text { Point }\end{array}$ & 15. Disposition (Provide justification if NOT accepted.) & $\begin{array}{l}16 . \\
\text { Status }\end{array}$ \\
\hline 4. & $\begin{array}{l}\text { Specification 01010, Part 1-Add new subparagraph } 1.6 .2 \text { to read as follows: } \\
\text { 1.6.2 Contractor shall schedule construction completion tests/inspections and } \\
\text { tumover of Structures, Systems, and Components (SSC) to the IC Startup } \\
\text { organization in accordance with the requirements of the testing/turnover } \\
\text { schedule to be prepared by the IC Startup. Such schedule shall be } \\
\text { consistent with the schedule for performance contained elsewhere in this } \\
\text { specification. }\end{array}$ & & & \\
\hline 5. & $\begin{array}{l}\text { Specification 01010, Part 1-Add new subparagraph } 1.6 .3 \text { to read as follows: } \\
\text { 1.6.3 Contractor shall perform inspection and testing as shown on the Testing } \\
\text { Interface Diagram (TID), Appendix X. The inspection and testing shall be } \\
\text { in accordance with Contract Drawings, Specifications, Inspection Plans, } \\
\text { and Construction Test Procedures. }\end{array}$ & & & {[} \\
\hline 6. & $\begin{array}{l}\text { Specification 01010, Part } 1 \text { - Add new subparagraph } 1.6 .4 \text { to read as follows: } \\
\text { 1.6.4 After Contractor Construction Acceptance Testing (CAT) has been } \\
\text { performed and approved on specific SSC, the Contractor shall arrange for } \\
\text { preliminary inspections and walkdowns with the Construction Manager, } \\
\text { IC Startup, and Operations and DOE-RL participants to establish the work } \\
\text { items remaining and list of exceptions. Work items and exceptions shall } \\
\text { be mutually agreed and documented on the Contractor punch list. The } \\
\text { punch list which will include a schedule for completion, at which time the } \\
\text { Contractor shall turnover that SSC to IC Startup for further inspection and } \\
\text { testing, as noted on the TD. }\end{array}$ & & & \\
\hline 7. & $\begin{array}{l}\text { Specification 01010, Part 1 - Add new subparagraph } 1.6 .5 \text { to read as follows: } \\
\text { 1.6.5 Contractor shall witness and/or verify and/or support inspection and testing } \\
\text { performed by IC Startup, as shown on the TID. }\end{array}$ & & & \\
\hline
\end{tabular}




\begin{tabular}{|l|l|l|}
\hline \multirow{2}{*}{ REVIEW COMMENT RECORD (RCR) } & $\begin{array}{l}\text { 1. Date } \\
\text { October 1, } 1996\end{array}$ \\
\cline { 2 - 4 } & $\begin{array}{c}\text { 3. Project No. } \\
\text { W-441 }\end{array}$ & $\begin{array}{c}\text { 4. Page } \\
3\end{array}$ \\
\hline
\end{tabular}

\begin{tabular}{|c|c|c|c|c|}
\hline $\begin{array}{l}12 . \\
\text { Item }\end{array}$ & $\begin{array}{l}\text { 13. Comment(s)/Discrepancy(s) (Provide technical justification for the comment and } \\
\text { detailed recommendation of the action required to correct/ resolve the discrepancy/problem } \\
\text { indicated.) }\end{array}$ & $\begin{array}{l}14 . \\
\text { Hold } \\
\text { Point }\end{array}$ & 15. Disposition (Provide justification if NOT accepted.) & $\begin{array}{l}16 . \\
\text { Status }\end{array}$ \\
\hline 8. & $\begin{array}{l}\text { Specification 01010, Part 1-Add new subparagraph } 1.6 .6 \text { to read as follows: } \\
\text { 1.6.6 Contractor shall grant the IC Startup and Operations personnel reasonable } \\
\text { access to the SSC during construction activities to support witness, } \\
\text { verification, and training activities. }\end{array}$ & & & $C$ \\
\hline 9. & $\begin{array}{l}\text { Specification } 01010 \text { - Add Appendix X, "Testing Interface Diagram", attached as } \\
\text { a separate file CVDTID. } 090 \text {. }\end{array}$ & & & \\
\hline 10. & $\begin{array}{l}\text { Specification 01036, Part 1, subsection 1.3.3. Often this is an RFI (Request for } \\
\text { Information), which can lead into an ECN. Right now, there is some confusion on } \\
\text { the procedural base, but we will center ourselves around the existing ICF KH desk } \\
\text { procedures until changed. Probably, the only immediate change to a procedure will } \\
\text { be to replace ICF KH with Fluor Daniel Northwest, or to simply delete ICF KH } \\
\text { reference. The procedure number would remain. This comment does not require } \\
\text { a response. }\end{array}$ & & None Required & $C$ \\
\hline 11. & $\begin{array}{l}\text { Specification 01040, Part } 1 \text {, subsection 1.3.3. At the end of the sentence, add "at no } \\
\text { charge to the Contractor". } \\
\text { Delete subsection 1.3.4. }\end{array}$ & & No action necessary & $C$ \\
\hline 12. & $\begin{array}{l}\text { Specification } 01040 \text {, Part } 1 \text { - Add a new item to read as follows: } \\
\text { "Contractor shall grant IC Startup and Operations personnel reasonable access to the } \\
\text { SSC during construction activities to support witness, verification, and training } \\
\text { activities". }\end{array}$ & & Added by Addendem $Z$ to IFB & $C$ \\
\hline 13. & $\begin{array}{l}\text { Specification } 01200 \text {, Part } 1 \text {, subsection } 1.4 .1 \text {. Add the following sentence at the end } \\
\text { of the paragraph, "Meeting frequency may be adjusted by the Construction Manager } \\
\text { based on need". }\end{array}$ & & No oction necesary & \\
\hline
\end{tabular}

声 


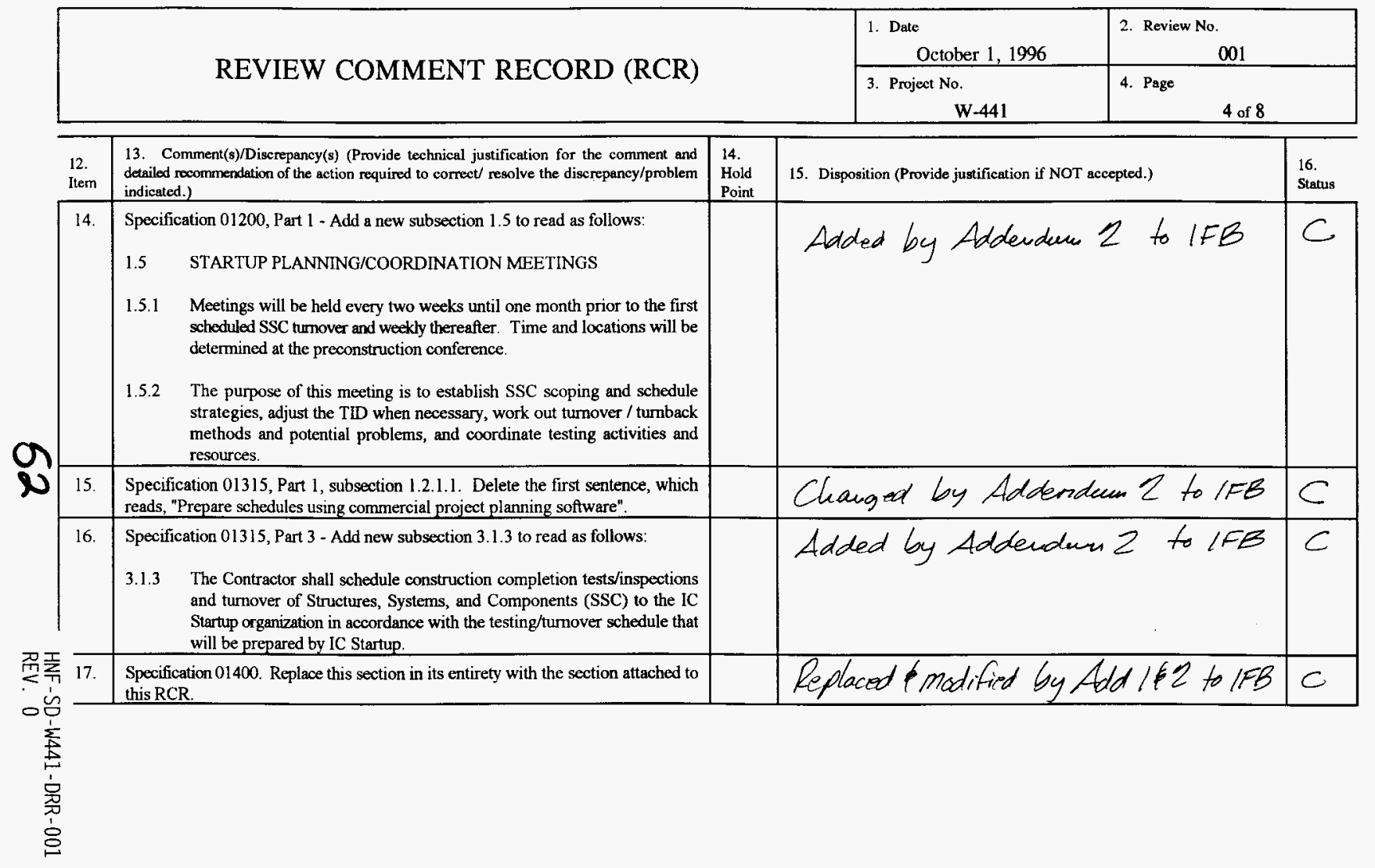




\begin{tabular}{|l|l|l|}
\hline \multirow{2}{*}{ REVIEW COMMENT RECORD (RCR) } & $\begin{array}{c}\text { 1. Date } \\
\text { October 1, 1996 Review No. }\end{array}$ & \multicolumn{2}{c|}{001} \\
\cline { 2 - 3 } & $\begin{array}{c}\text { 3. Project No. } \\
\text { W-441 }\end{array}$ & $\begin{array}{c}\text { 4. Page } \\
5 \text { of } 8\end{array}$ \\
\hline
\end{tabular}

\begin{tabular}{|c|c|c|c|c|}
\hline $\begin{array}{l}12 . \\
\text { Item }\end{array}$ & $\begin{array}{l}\text { 13. Comment(s)/Discrepancy(s) (Provide technical justification for the comment and } \\
\text { detailed rocommendation of the action required to correct/ resolve the discrepancy/problem } \\
\text { indicated.) }\end{array}$ & $\begin{array}{l}14 . \\
\text { Hold } \\
\text { Point }\end{array}$ & 15. Disposition (Provide justification if NOT accepted.) & $\begin{array}{l}16 . \\
\text { Stahus }\end{array}$ \\
\hline 18. & $\begin{array}{l}\text { Specification 01630 - Add this new section, as follows: } \\
\text { SECTION } 01630 \\
\text { PRODUCT OPTIONS AND SUBSTITUTIONS } \\
\text { PART 1- GENERAL } \\
1.1 \quad \text { SUBMITTALS } \\
1.1 .1 \quad \text { See Section 01300 for submittal procedures. } \\
1.1 .2 \quad \begin{array}{l}\text { Approval Required: Before starting Work, submit a completed } \\
\text { substitution Approval Request (Form KEH 1151) for each requested } \\
\text { substitution. }\end{array}\end{array}$ & & Added by Add. 2 to $1 F B$ & $C$ \\
\hline 19. & $\begin{array}{l}\text { Specification } 01630 \text { - Continue new section as follows: } \\
\text { 1.2 CONDITIONS } \\
\text { 1.2.1 Products include those identified in this Specification and on drawings. } \\
\text { General Conditions Section } 13 \text { and following conditions and limitations } \\
\text { apply. } \\
\text { 1.2.2 Substitution requires approval if any of the following apply. } \\
\text { 1.2.2.1 Proposed substitute is more hazardous than specified product. } \\
\text { 1.2.2.2 Product callout includes the phrase "or } \\
\text { approved substituten }\end{array}$ & & & $C$ \\
\hline
\end{tabular}




\begin{tabular}{|c|c|c|}
\hline \multirow{2}{*}{ REVIEW COMMENT RECORD (RCR) } & $\begin{array}{l}\text { 1. Date } \\
\text { October 1, } 1996\end{array}$ & $\begin{array}{l}\text { 2. Review No. } \\
\qquad 001 \\
\end{array}$ \\
\hline & $\begin{array}{l}\text { 3. Project No. } \\
\text { W-441 }\end{array}$ & 4. Page \\
\hline
\end{tabular}

\begin{tabular}{|c|c|c|c|c|}
\hline $\begin{array}{l}12 . \\
\text { Item }\end{array}$ & $\begin{array}{l}\text { 13. Comment(s)/Discrepancy(s) (Provide technical justification for the comment and } \\
\text { detailed recommendation of the action required to correct/resolve the discrepancy/problem } \\
\text { indicated.) }\end{array}$ & $\begin{array}{l}14 . \\
\text { Hold } \\
\text { Point }\end{array}$ & 15. Disposition (Provide justification if NOT accepted.) & $\begin{array}{l}16 . \\
\text { Status }\end{array}$ \\
\hline 20. & $\begin{array}{l}\text { Specification } 01630 \text { - Continue new section as follows: } \\
\text { 1.2.3 A substitute may be provided without approval if each of the following } \\
\text { apply. } \\
\text { 1.2.3.1 Product callout does not include the phrase "or approved substitute". } \\
\text { 1.2.3.2 Product is identified in this Specification by trade name, make, or catalog } \\
\text { number. } \\
\text { 1.2.3.3 Substitute is equivalent in function, maintainability, reliability, durability, } \\
\text { material content, form, and size. }\end{array}$ & & & $C$ \\
\hline 21. & $\begin{array}{l}\text { Specification } 01630 \text { - Continue new section as follows: } \\
\text { 1.2.4 } \begin{array}{l}\text { Substitution shall be applied to total quantity of product required in } \\
\text { specification. Partial quantity substitutions are not acceptable. }\end{array} \\
\text { 1.2.5 Approval of fabrication drawings and other design media does not } \\
\text { constitute approval of substitute products identified within the media. } \\
\text { 1.2.6 } \begin{array}{l}\text { Submittals required for a specific item are also required for approved } \\
\text { substitute. }\end{array}\end{array}$ & & & $\subset$ \\
\hline 22. & $\begin{array}{l}\text { Specification } 01630 \text { - Continue new section as follows: } \\
\text { 1.3 REQUEST PREPARATION } \\
\text { 1.3.1 Using the Substitution Approval Request, identify addressed product by } \\
\begin{array}{l}\text { Specification Section and article or paragraph numbers or by Drawing } \\
\text { number. Provide manufacturer's name and address, trade name, and model } \\
\text { or catalog number. List fabricators as appropriate. }\end{array} \\
\end{array}$ & & & $c$ \\
\hline
\end{tabular}




\begin{tabular}{|l|l|l|}
\hline \multirow{2}{*}{ REVIEW COMMENT RECORD (RCR) } & $\begin{array}{l}\text { 1. Date } \\
\text { October 1, 1996 Review No. }\end{array}$ & \multicolumn{2}{c|}{001} \\
\cline { 2 - 3 } & $\begin{array}{c}\text { 3. Project No. } \\
\text { W-441 }\end{array}$ & 7 of 8 \\
\hline
\end{tabular}

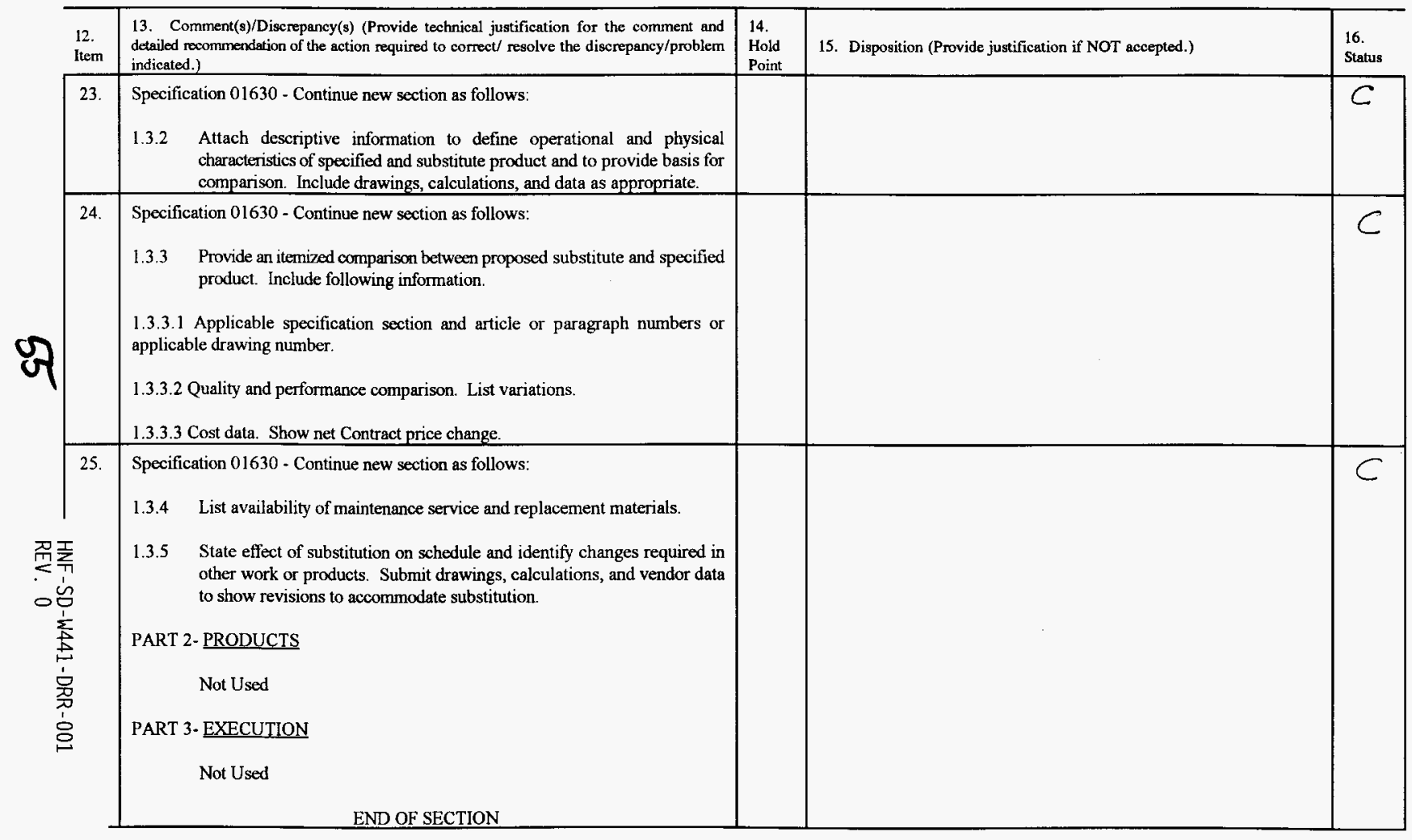




\begin{tabular}{|l|l|l|}
\hline \multirow{2}{*}{ REVIEW COMMENT RECORD (RCR) } & $\begin{array}{l}\text { 1. Date } \\
\text { October 1, 1996 Review No. }\end{array}$ & \multicolumn{1}{c|}{001} \\
\cline { 2 - 3 } & $\begin{array}{c}\text { 3. Projcct No. } \\
\text { W-441 }\end{array}$ & $\begin{array}{c}\text { 4. Page } \\
8\end{array}$ \\
\hline
\end{tabular}

\begin{tabular}{|c|c|c|c|c|}
\hline $\begin{array}{l}12 . \\
\text { Item }\end{array}$ & $\begin{array}{l}\text { 13. Comment(s)/Discrepancy(s) (Provide technical justification for the comment and } \\
\text { detailod recommendation of the action required to correct/ resolve the discrepancy/problem } \\
\text { indicated.) }\end{array}$ & $\begin{array}{l}14 . \\
\text { Hold } \\
\text { Point }\end{array}$ & 15. Disposition (Provide justification if NOT accepted.) & $\begin{array}{l}16 . \\
\text { Status }\end{array}$ \\
\hline 26. & $\begin{array}{l}\text { H-1-82090-1-3-0 Sheet numbering indicates there are two more sheets (probably } \\
\text { general notes, legend, abbreviations, etc). Only one sheet is in the drawing list. This } \\
\text { situation is probably true in many other places, based on how much reduced the } 90 \% \\
\text { set is from the } 60 \% \text { set. We will presume the drawing list is representative of only } \\
\text { those drawings intended to be in the } 90 \% \text { package and does not give the true extent } \\
\text { of the expected final drawing package. Work scope will be clarified accordingly. } \\
\text { Please confirm. }\end{array}$ & & Corrected. & \\
\hline 27. & $\begin{array}{l}\text { H-1-82092-1-1-0 Flag } 23 \text { indicates "(E) Corrugated metal caisson to be removed". } \\
\text { The caisson and the french drain which it protects are under the existing Bechtel } \\
\text { umbrella for remediation. It is they who will do the removal and disposal of the } \\
\text { protective CMP. The timing for this is dependent on Bechtel's schedule. Indications } \\
\text { from their personnel are that remediation may not occur until after the year } 2000 \text {. } \\
\text { We should probably plan on this item being a permanent fixture on site. } \\
\text { Provide a communications handhole in the communications conduit run at the bend } \\
\text { located near hydraulic calculation reference node UG2. }\end{array}$ & & $\begin{array}{l}\text { (NIC) Added to note. } \\
\text { will be haudled on as-boilts } \\
\text { Eequireneut is by Site comm, who will requine } \\
\text { Not accepted. Not required at this location for installation. handhale }\end{array}$ & $C$ \\
\hline 28. & $\begin{array}{l}\text { H-1-82093-1-1-0 This drawing shows much more than the "scanned utilities". It } \\
\text { is also presenting the existing rough grade configuration, essential for pricing. } \\
\text { However, insufficient data is included with the rough grading to properly interpret } \\
\text { the information. The plan should be larger and should include survey point data, } \\
\text { which was provided with the rough grading as-builts. }\end{array}$ & & $\begin{array}{l}\text { Agreed. Not changed. Using H-1-82100 } \\
\text { as existing couditions, rather } \\
\text { than do-buit. Not proper but } \\
\text { uorkable and acceptable. }\end{array}$ & $C$ \\
\hline 9. & $\begin{array}{l}\text { H-1-82101-1-1-0 The term "DI" was not added to the legend to identify the term as } \\
\text { "deionized" (reference room } 120 \text { ). The response to the same RCR item for the } 60 \% \\
\text { design review indicated that this would be done. }\end{array}$ & & The abbreviation for DI shall be identified. & 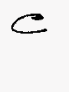 \\
\hline & $\begin{array}{l}\text { Provide an elevation correlation between first floor elevation } 100.00 \text { and site } \\
\text { elevation } 476.00 \text { for clarification. Suggest doing this at new note } 3 \text {. H-1-82092-1- } \\
1-0 \text {, "Site Plan", shows CVDF TC } 476.00 \text { '. The note will help clarify that both } \\
\text { references are one and the same and avoid errors during survey of the work. }\end{array}$ & & A correlation elevation shall be added for clarification. & $C$ \\
\hline
\end{tabular}




\begin{tabular}{|l|l|l|}
\hline \multirow{2}{*}{ REVIEW COMMENT RECORD (RCR) } & $\begin{array}{l}\text { 1. Date } \\
10 / 03 / 96\end{array}$ \\
\cline { 2 - 3 } & $\begin{array}{c}\text { 3. Project No. } \\
\text { W-441 }\end{array}$ \\
\hline
\end{tabular}

\begin{tabular}{|l|l|l|l|l|}
\hline 5. Document Number(s)/Title(s) & $\begin{array}{l}\text { 6. Program/Project/ } \\
\text { Building Number } \\
\text { SNFP/W-441- }\end{array}$ & 7. Reviewer & WC Alaconis & Organization/Group \\
Cold Vacuum Drying Facility & C1/CVD & $\begin{array}{l}\text { SNFP/Fuel Handling } \\
\text { Operations }\end{array}$ \\
\hline
\end{tabular}

17. Comment Submittal Approval:

Organization Manager (Optional)
10. Agreement with indicated comment disposition(s)

10. Agreement with indicated comment disposition(s)

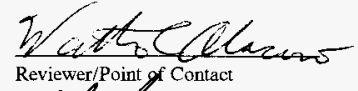

Reviewer/Point of Contact
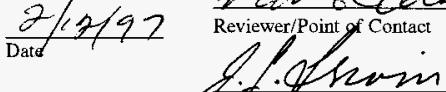

in

11. CLOSED
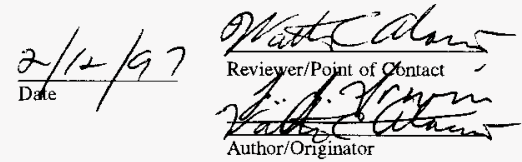

\begin{tabular}{|c|c|c|c|c|}
\hline $\begin{array}{l}12 . \\
\text { Item }\end{array}$ & $\begin{array}{l}\text { 13. Comment(s)/Discrepancy(s) (Provide technical justification for the comment and } \\
\text { detailed recommendation of the action required to correct/ resolve the discrepancy/problem } \\
\text { indicated.) }\end{array}$ & $\begin{array}{l}14 . \\
\text { Hold } \\
\text { Point }\end{array}$ & 15. Disposition (Provide justification if NOT accepted.) & $\begin{array}{l}16 . \\
\text { Status }\end{array}$ \\
\hline 1 & $\begin{array}{l}\text { Several comments (from this originator) that were accepted during the } 60 \% \text { review } \\
\text { have not been incorporated into the design. Specifically comments numbers, } 1 \text {, } \\
3,4,5,7,8,9,14,18,24 \text {. }\end{array}$ & Y & $\begin{array}{l}\text { 1. Will avoid company names in spec to avoid confusion. } \\
\text { 3. Leslie } \\
\text { 4. Duke } \\
\text { 5. Meier } \\
\text { 7. Duke/Meier } \\
\text { 8. All, we are using SHC supplied standards. } \\
\text { 9. All, process bay shielding as is, RLW under evaluation. } \\
\text { 14. Merrick HVAC } \\
\text { 18. All automatic valves have visual indication and remote indication. } \\
\quad \text {-PCV are self actuated and are not available with position } \\
\text { indication use down or up stream PI. } \\
\text {-Solenoid valves are not available in position indication--must use } \\
\text { process telemetry to determin a valve position if required. } \\
\text { 24. Meier. }\end{array}$ & \\
\hline 2 & $\begin{array}{l}\text { The design as presented is too broken-up. A narrative Definitive Design Report } \\
\text { is required for a through review. As presented operations can not develop training } \\
\text { plans, procedures etc... By the } 100 \% \text { submittal, a preliminary Operations and } \\
\text { Maintenance Manual should be submitted for review. }\end{array}$ & Y & $\begin{array}{l}\text { O\&M manuals will be prepared and a Definitive Design Report } \\
\text { provided. }\end{array}$ & \\
\hline
\end{tabular}

8 


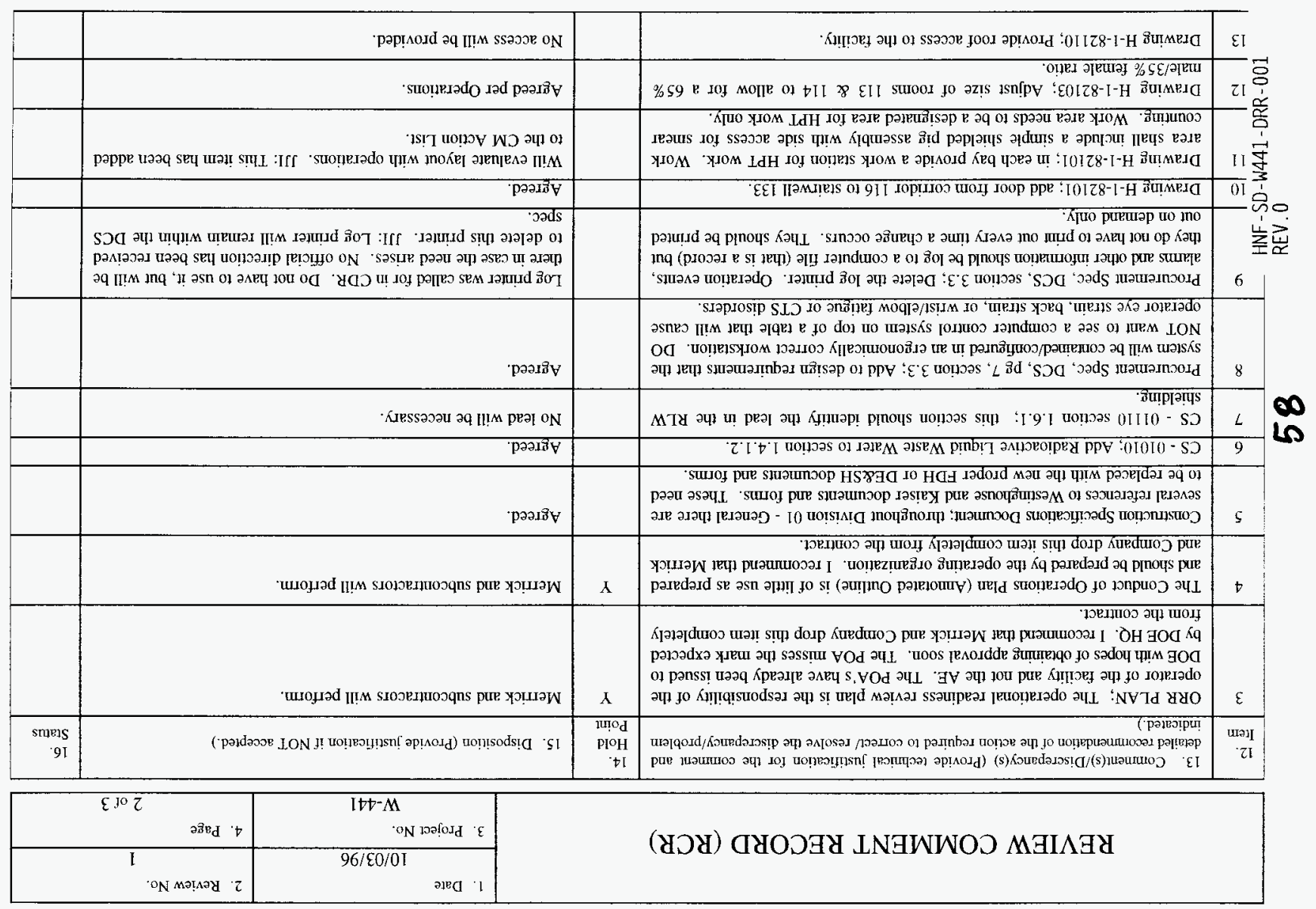




\begin{tabular}{|c|c|c|}
\hline \multirow{2}{*}{ REVIEW COMMENT RECORD (RCR) } & $10 / 03 / 96$ & $\begin{array}{r}\text { 2. Review No. } \\
1\end{array}$ \\
\hline & $\begin{array}{l}\text { 3. Project No. } \\
\text { W-441 }\end{array}$ & 4. Page \\
\hline
\end{tabular}

\begin{tabular}{|c|c|c|c|c|}
\hline $\begin{array}{l}12 . \\
\text { Item }\end{array}$ & $\begin{array}{l}\text { 13. Comment(s)/Discrepancy(s) (Provide technical justification for the comment and } \\
\text { detailed recommendation of the action required to correc// resolve the discrepancy/problem } \\
\text { indicated.) }\end{array}$ & $\begin{array}{l}14 . \\
\text { Hold } \\
\text { Point }\end{array}$ & 15. Disposition (Provide justification if NOT accepted.) & $\begin{array}{l}16 . \\
\text { Status }\end{array}$ \\
\hline 14 & $\begin{array}{l}\text { Drawing H-1-82112; make the following changes to the door schedule; } \\
\text { 1) Change door } 18 \text { to a C type. } \\
\text { 2) Change doors } 22 \text { and } 24 \text { to a B type. } \\
\text { 3) Door } 51 \text { shows } 2 \text { under number but only one on the } 82101 \text { drawing. } \\
\text { 4) Add a comment in remarks for doors that are normally emergency exit only. }\end{array}$ & & $\begin{array}{l}\text { 1) Agreed. Dot Doce } \\
\text { 2) Agreed. ox } \\
\text { 3) Door } 51 \text { is one door. }=\text {; xel } \\
\text { 4) Agreed. Signage shall be provided. Oone }\end{array}$ & \\
\hline 15 & $\begin{array}{l}\text { Drawing H-1-82164; Can not refer to DWG H-3-52300 since it is not provided. } \\
\text { Details of this cloud are required. }\end{array}$ & & $\begin{array}{l}\text { Because late change to RLW system, P\&ID was only definition of } \\
\text { RLW system. Complete design will be included in final design. }\end{array}$ & \\
\hline 16 & General Note; 1) provide a schedule of all valves. & & $\begin{array}{l}\text { We will call for valve schedule from Contractor and add a valve } \\
\text { schedule format. } \\
\text { Process valve list will be printed in specs along with instruments, } \\
\text { equipment, and specialty items. }\end{array}$ & \\
\hline
\end{tabular}




\begin{tabular}{|l|l|l|}
\hline \multirow{2}{*}{ REVIEW COMMENT RECORD (RCR) } & 1. Date 2. Review No. & $10 / 3 / 96$ \\
\cline { 2 - 3 } & $\begin{array}{c}\text { 3. Project No. } \\
\text { W-441-C1 }\end{array}$ & $\begin{array}{l}\text { 4. Page } \\
1\end{array}$ \\
\hline
\end{tabular}

\begin{tabular}{|l|l|l|l|l|}
\hline 5. Document Number(s)/Title(s) & $\begin{array}{l}\text { 6. Program/Project/ } \\
\text { Building Number } \\
\text { SNF/CVDF/142K }\end{array}$ & 7. Reviewer & 8. Organization/Group \\
$\begin{array}{l}\text { Cold Vacuum Drying Facility 90\% Design } \\
\text { Review }\end{array}$ & S. Debban & SNFP Operations \\
\hline
\end{tabular}

17. Comment Submittal Approval:

Organization Manager (Optional)
10. Agreement with indicated comment (isposition (s)

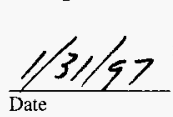

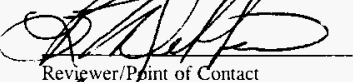

Revigwer/Ppint of Contact Litrown
11. CLOSED
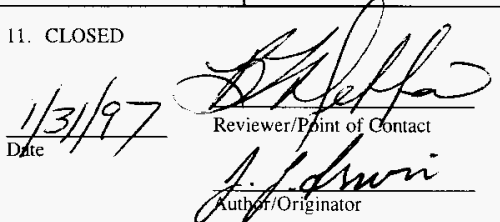

13. Comment(s)/Discrepancy(s) (Provide technical justification for the comment and detailed recommendation of the action required to correct/ resolve the

discrepancy/problem indicated.)

1. The Operational readiness review plan is the responsibility of the operator of the facility and not the AE. The POA's have already been issued to DOE for review with hopes of obtaining approval soon. The POA misses the mark expected by DOE HQ. I recommend that Merrick and Company drop this item completely from the contract.

2. The Conduct of Operations Plan (Annotated outline) is of little use as prepared and should be prepared by the operating organization. I

recommend that Merrick and Company drop this item completely from the contract.

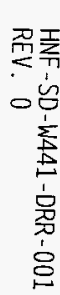

\begin{tabular}{|l|l|l|}
\hline $\begin{array}{l}\text { 14. } \\
\text { Point }\end{array}$ & 15. Disposition (Provide justitication if NOT accepted.) & $\begin{array}{l}16 . \\
\text { Status }\end{array}$ \\
\hline & Merrick will provide with client's input. & 6 \\
& & o \\
& Merrick will provide with client's input. & 5 \\
& & 5 \\
\hline & & 5 \\
\hline
\end{tabular}




\begin{tabular}{|l|l|l|}
\hline \multirow{2}{*}{ REVIEW COMMENT RECORD (RCR) } & $\begin{array}{l}\text { 1. Date } \\
10-11-96\end{array}$ & $\begin{array}{c}\text { Review No. } \\
\text { CVD-011-A }\end{array}$ \\
\cline { 2 - 4 } & $\begin{array}{c}\text { 3. Project No. } \\
\text { W-441 }\end{array}$ & $\begin{array}{l}\text { 4. Page } \\
1 \text { of } 9\end{array}$ \\
\hline
\end{tabular}

11-22-96:

My review of the RCR dispositions are noted below. Problem areas are noted, and additional comments are provided on the last page. I provided dispositions for items 1-9 since none were provided. Where "CLOSED" appears, the disposition is acceptable and I am prepared to sign off. Where my initials appear in column 14, additional actions are required to close the comment, or the disposition is unacceptable and needs revision.

\section{Brian Fillion. $376-1218$}

5. Document Number(s)/Title(s)

Construction Spec. W-441-C1, 90\%

Review. Sept./October 1996.

\begin{tabular}{|l|l|}
$\begin{array}{l}\text { 6. Program/Project/ } \\
\text { Building Number } \\
\text { Project } W-441\end{array}$ & Brian Fillion \\
Bldg. $142 \mathrm{~K}$ & \\
\hline
\end{tabular}

8. Organization/Group
SNF Project QA

9. Location/Phone TCPC Room 54 $376-1218$

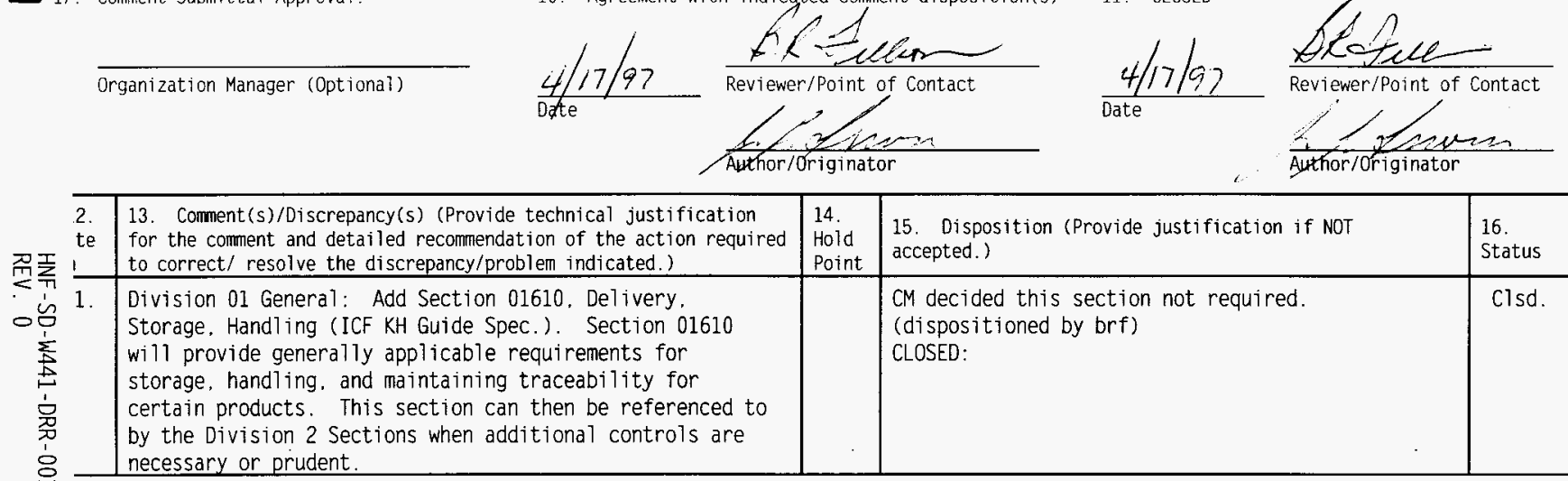




\begin{tabular}{|l|l|l|}
\hline \multirow{2}{*}{ REVIEW COMMENT RECORD (RCR) } & $\begin{array}{l}\text { 1. Date Review No. } \\
\text { CVD-011-A }\end{array}$ \\
\cline { 2 - 4 } & $\begin{array}{c}\text { 3. Project No. } \\
W-441\end{array}$ & $\begin{array}{l}4.96 \\
\text { Page }\end{array}$ \\
\hline
\end{tabular}

\begin{tabular}{|c|c|c|c|c|}
\hline $\begin{array}{l}12 . \\
\text { Ite } \\
\text { in }\end{array}$ & $\begin{array}{l}\text { 13. Comment(s)/Discrepancy(s) (Provide technical justification } \\
\text { for the comment and detailed recommendation of the action required } \\
\text { to correct/ resolve the discrepancy/problem indicated.) }\end{array}$ & $\begin{array}{l}14 . \\
\text { Hold } \\
\text { Point } \\
\end{array}$ & $\begin{array}{l}\text { 15. Disposition (Provide justification if NOT } \\
\text { accepted.) }\end{array}$ & $\begin{array}{l}16 . \\
\text { Status }\end{array}$ \\
\hline 2. & $\begin{array}{l}\text { Division } 01 \text { Genera 1: Add Section 01630. Product } \\
\text { Substitutions (ICF KH Guide Spec.) }\end{array}$ & brf & $\begin{array}{l}\text { Added by Add. \# } 2 \text { to Bid Package. Will be } \\
\text { incorporated into Spec. by DCN \# ???? (dispos. by } \\
\text { brf) }\end{array}$ & Clsd. \\
\hline 3. & $\begin{array}{l}\text { Section 01010: Revise to reflect latest scope of work } \\
\text { applicable for the } \mathrm{Cl} \text { Contract. }\end{array}$ & & CLOSED. & Clsd. \\
\hline 4. & $\begin{array}{l}\text { Section 01036: } \\
\text { a) Para. 1.3.3: Project should evaluate if "Field ECN" } \\
\text { is prudent. A11 ECNs will comply with established } \\
\text { procedures for design control, whether Safety Class or } \\
\text { Safety Significant items. The field ECN may cause more } \\
\text { problems rather than be a help. Need to clarify the } \\
\text { intent of process. } \\
\text { b) Para. 3.1.1: Revise this section to incorporate the } \\
\text { latest changes in the ECN form, ie, block numbers have } \\
\text { changed with the latest revision of the ECN form. }\end{array}$ & & $\begin{array}{l}\text { a) Per CM (Abbott/Gauthier) this is not a } \\
\text { problem. (dispos. by brf) } \\
\text { CLOSED: } \\
\text { b) Referred to CM to correct at their } \\
\text { Convenience. (Dispo. by brf) } \\
\text { CLOSED: }\end{array}$ & Clsd. \\
\hline 5. & $\begin{array}{l}\text { Section } 01300 \text {. Para. 1.4.2.: Global Comment: Number of } \\
\text { copies of submitted documents will be governed by this } \\
\text { Section. If } 10 \text { copies of an item submitted for approval } \\
\text { is an excessive number. then the appropriate number of } \\
\text { copies should be delineated in the individual technical } \\
\text { sections. }\end{array}$ & & $\begin{array}{l}\text { For information comment only for consideration by } \\
\text { AE/CM. (Dispo. by brf) } \\
\text { CLOSED: }\end{array}$ & Clsd. \\
\hline 6 & $\begin{array}{l}\text { Section 01400: This section has to be replaced with } \\
\text { requirements consistent with Safety Equipment List (SEL) } \\
\text { safety class designations. }\end{array}$ & & $\begin{array}{l}\text { To be supplied by QA. (Brian Fillion) } \\
\text { CLOSED: }\end{array}$ & Clsd. \\
\hline
\end{tabular}




\begin{tabular}{|l|l|l|}
\hline \multirow{2}{*}{ REVIEW COMMENT RECORD (RCR) } & $\begin{array}{l}\text { 1. Date } \\
10-11-96\end{array}$ & $\begin{array}{c}\text { 2. Review No. } \\
\text { CVD-011-A }\end{array}$ \\
\cline { 2 - 4 } & $\begin{array}{c}\text { 3. Project No. } \\
\text { W-441 }\end{array}$ & $\begin{array}{l}\text { 4. Page } \\
3 \text { of } 9\end{array}$ \\
\hline
\end{tabular}

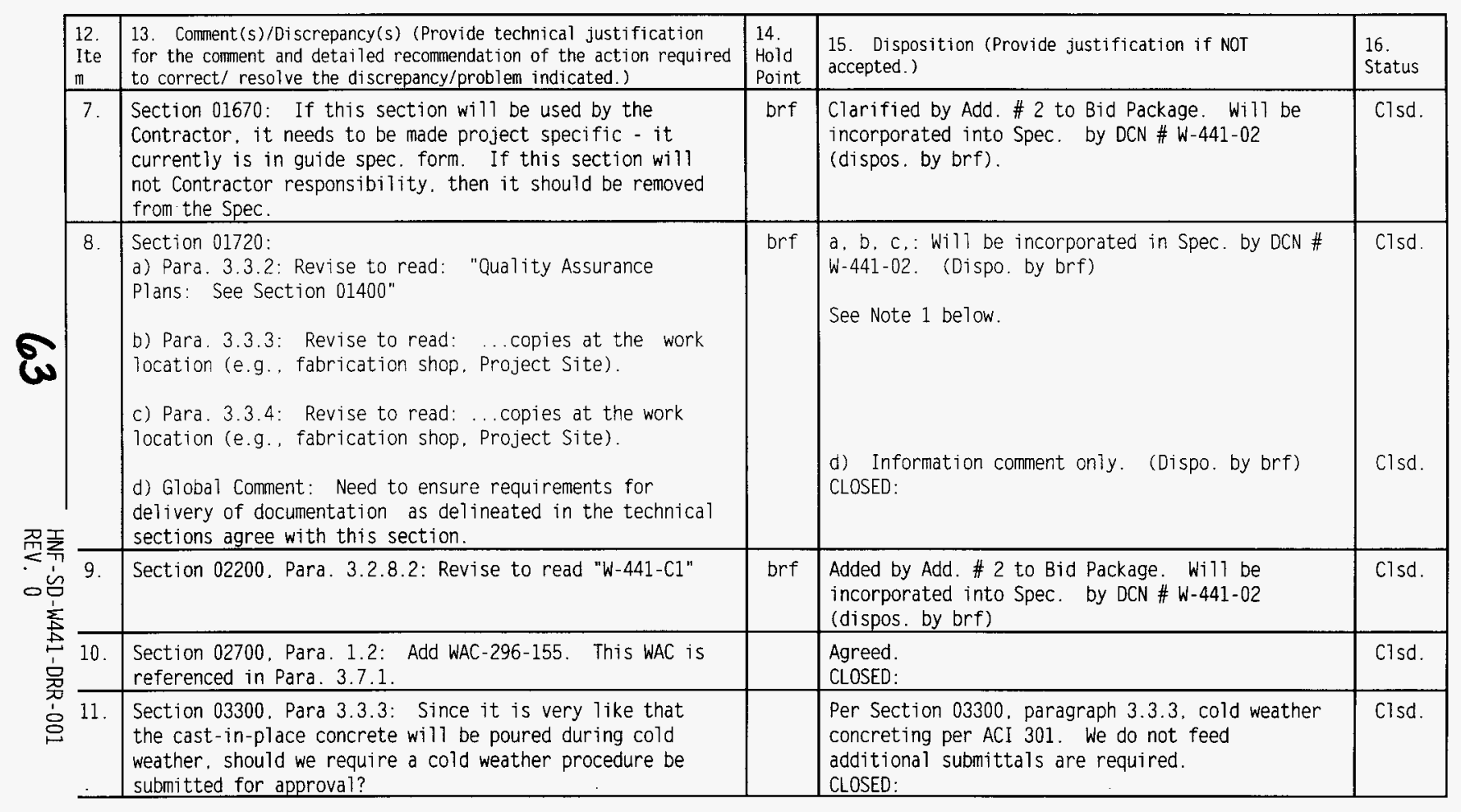




\begin{tabular}{|l|l|l|l|}
\hline \multirow{2}{*}{ REVIEW COMMENT RECORD (RCR) } & $\begin{array}{l}\text { Date } \\
10-11-96\end{array}$ \\
\cline { 2 - 3 } & $\begin{array}{c}\text { 3. Project No. } \\
\text { W-441 }\end{array}$ \\
\hline
\end{tabular}

\begin{tabular}{|c|c|c|c|c|}
\hline $\begin{array}{l}12 . \\
\text { Ite } \\
m\end{array}$ & $\begin{array}{l}\text { 13. Comment(s)/Discrepancy(s) (Provide technical justification } \\
\text { for the comment and detailed recommendation of the action required } \\
\text { to correct/ resolve the discrepancy/problem indicated.) }\end{array}$ & $\begin{array}{l}14 . \\
\text { Hold } \\
\text { Point }\end{array}$ & $\begin{array}{l}\text { 15. Disposition (Provide justification if NOT } \\
\text { accepted.) }\end{array}$ & $\begin{array}{l}16 . \\
\text { Status }\end{array}$ \\
\hline 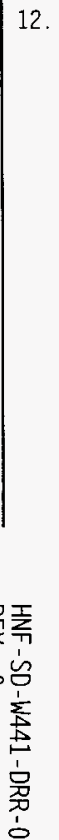 & $\begin{array}{l}\text { Section 03400: Based on the new SEL. inspections should } \\
\text { be commensurate with QA Level } 2 \text { (Safety Class 2). } \\
\text { a)Para. 1.6.2: This is weak: Suggest changing to read } \\
\text { "Welders and welding shall be in accordance with AwS } \\
\text { D1.1." } \\
\text { b)Para. 1.4: Fabricator will be performing stud welding, } \\
\text { and some structural welding. Need to address welder. } \\
\text { welding, or welding inspection personnel requirements. } \\
\text { (See Section 05100 for reference) } \\
\text { c)Para. 3.3: Provide weld inspection acceptance criteria } \\
\text { for erection welding, welding inspector qualifications. } \\
\text { d)Para. 3.3: Provide directions to inspect all joints and } \\
\text { seals associated with erection of the panels. Ensure } \\
\text { inspection acceptance criteria is clear and includes } \\
\text { tolerances, state that the inspections shall be } \\
\text { documented. } \\
\text { e)Para. } 3.4 \text { : What concrete tests and inspections during } \\
\text { the panel fabrication process are needed, and will cm } \\
\text { inspection personnel be involved? }\end{array}$ & brf & 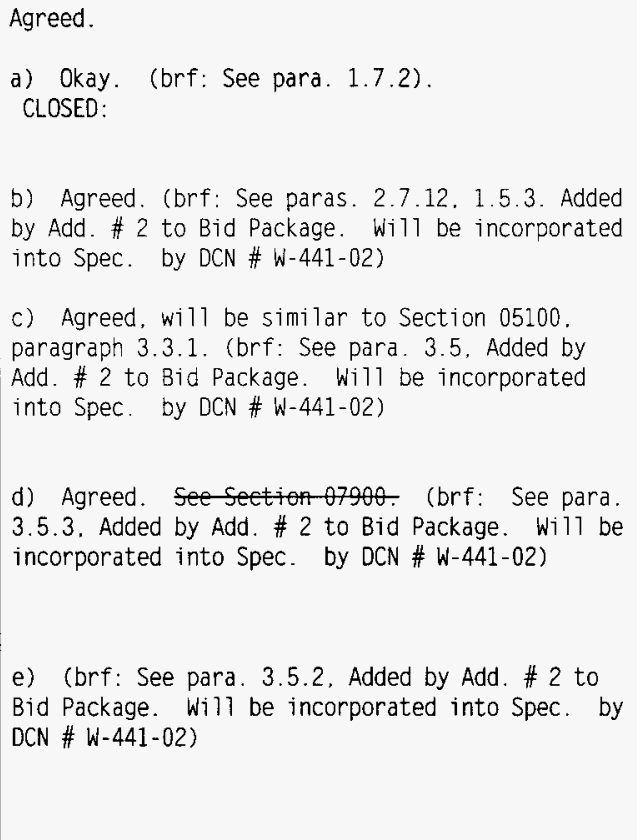 & $\begin{array}{l}\text { clsd. } \\
\text { clsd. }\end{array}$ \\
\hline
\end{tabular}




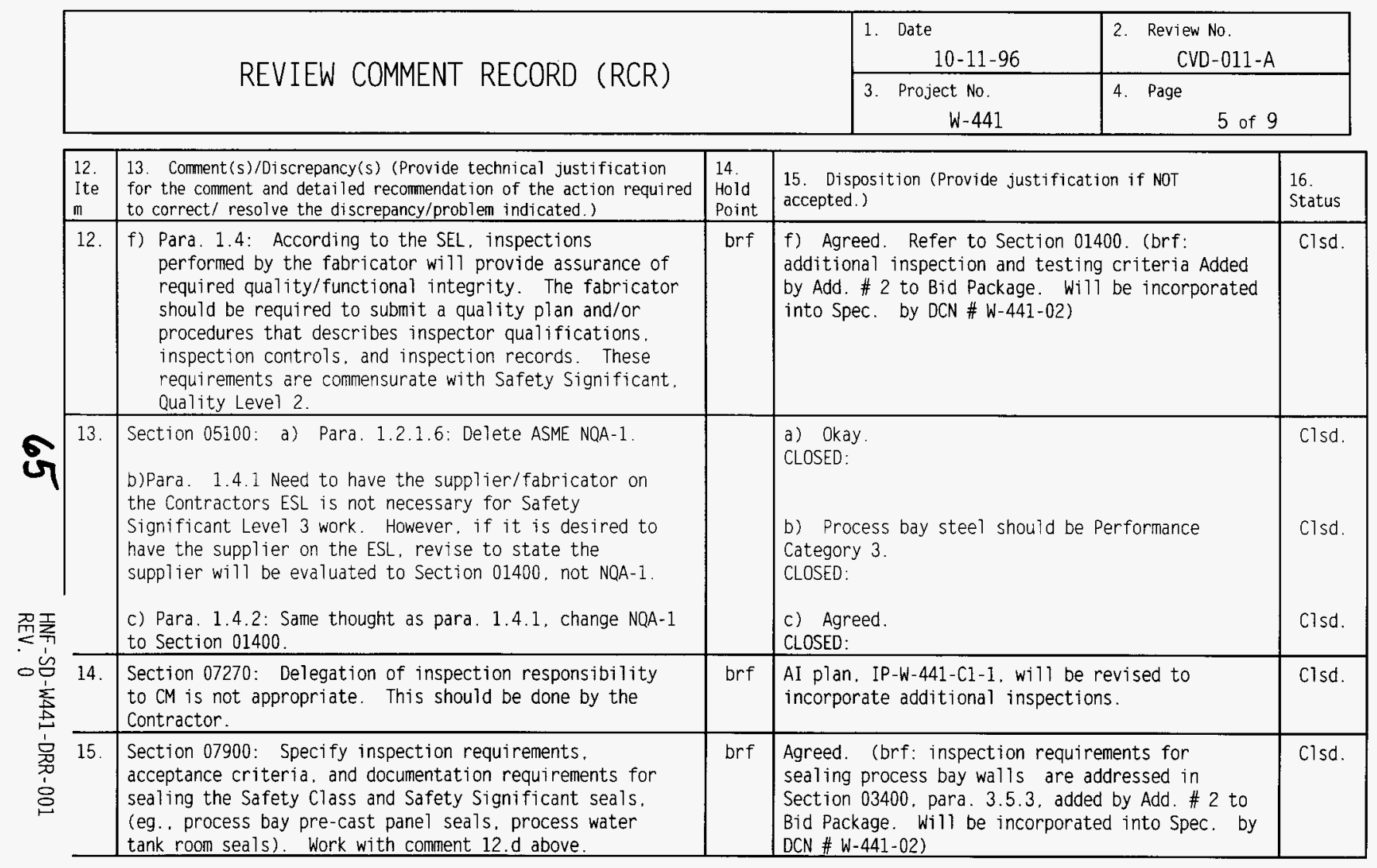




\begin{tabular}{|l|l|l|}
\hline \multirow{2}{*}{ REVIEW COMMENT RECORD (RCR) } & $\begin{array}{l}\text { 1. Date } \\
10-11-96\end{array}$ & $\begin{array}{r}\text { 2. Review No. } \\
\text { CVD-011-A }\end{array}$ \\
\cline { 2 - 4 } & $\begin{array}{c}\text { 3. Project No. } \\
\text { W-441 }\end{array}$ & $\begin{array}{l}\text { 4. Page } \\
6 \text { of } 9\end{array}$ \\
\hline
\end{tabular}

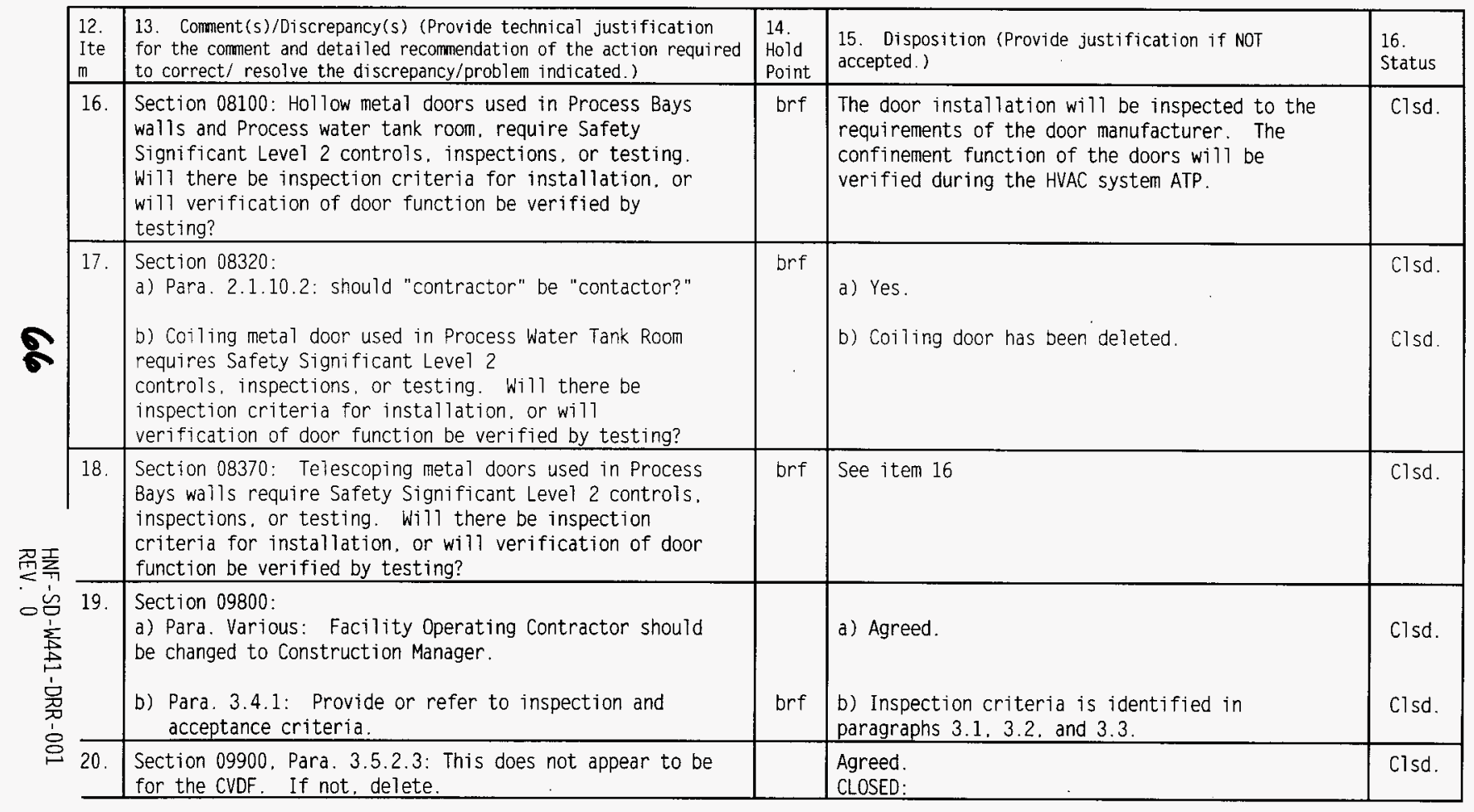




\begin{tabular}{|l|l|l|}
\hline \multirow{2}{*}{ REVIEW COMMENT RECORD (RCR) } & $\begin{array}{l}\text { 1. Date } \\
10-11-96\end{array}$ & $\begin{array}{c}\text { 2. Review No. } \\
\text { CVD-011-A }\end{array}$ \\
\cline { 2 - 4 } & $\begin{array}{c}\text { 3. Project No. } \\
\text { W-441 }\end{array}$ & $\begin{array}{l}\text { 4. Page } \\
7 \text { of } 9\end{array}$ \\
\hline
\end{tabular}

\begin{tabular}{|c|c|c|c|c|}
\hline $\begin{array}{l}12 . \\
\text { Ite } \\
\text { m }\end{array}$ & $\begin{array}{l}\text { 13. Comment(s)/Discrepancy(s) (Provide technical justification } \\
\text { for the comment and detailed recommendation of the action required } \\
\text { to correct/ resolve the discrepancy/problem indicated.) }\end{array}$ & \begin{tabular}{|l|}
14. \\
Hold \\
Point
\end{tabular} & $\begin{array}{l}\text { 15. Disposition (Provide justification if NOT } \\
\text { accepted.) }\end{array}$ & $\begin{array}{l}16 . \\
\text { Status }\end{array}$ \\
\hline 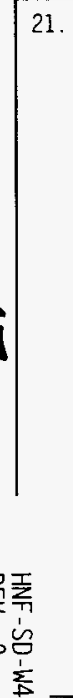 & $\begin{array}{l}\text { Section } 13120 \text { : The Process Water Tank Room has Quality } \\
\text { Level } 2 \text { inspection requirements per the SEL. For the } \\
\text { PWTR, this section needs to address following: } \\
\text { a) Welder and welding procedure qualifications. } \\
\text { b) Welding inspection criteria, including welding } \\
\text { inspector qualifications. } \\
\text { c) Inspection criteria for joints and seals related to } \\
\text { wall panel and roof panel installations. Inspection } \\
\text { criteria sha } 11 \text { include acceptance criteria and should } \\
\text { require the inspections to be documented. } \\
\text { d) According to the SEL. inspections performed by the } \\
\text { fabricator/erector will provide assurance of required } \\
\text { quality/functional integrity. The fabricator/erector } \\
\text { should be required to submit a quality plan and/or } \\
\text { procedures that describes inspector qualifications, } \\
\text { inspection controls. and inspection records. These } \\
\text { requirements are commensurate with Safety Significant. } \\
\text { Quality Level } 2 \text {. (Note: The inspections could be } \\
\text { performed under the contractors QA program) }\end{array}$ & & $\begin{array}{l}\text { Section } 13120 \text { will not be applied to this room. } \\
\text { PWTR wi } 11 \text { be covered by } 03400 \text { (Precast Concrete) } \\
\text { and } 05100 \text { (Steel) and others as appropriate. } \\
\text { These sections currently cover QA requirements. } \\
\text { CLOSED: }\end{array}$ & Clsd. \\
\hline
\end{tabular}




\begin{tabular}{|l|l|l|}
\hline \multirow{2}{*}{ REVIEW COMMENT RECORD (RCR) } & $\begin{array}{l}\text { Date Review No. } \\
\text { CVD-011-A }\end{array}$ \\
\cline { 2 - 4 } & $\begin{array}{c}\text { 3. Project No. } \\
\text { W-441 }\end{array}$ \\
\hline
\end{tabular}

\begin{tabular}{|c|c|c|c|c|}
\hline $\begin{array}{l}1 \\
\text { I } \\
\text { II }\end{array}$ & $\begin{array}{l}\text { 13. Comment(s)/Discrepancy(s) (Provide technical justification } \\
\text { for the comment and detailed recommendation of the action required } \\
\text { to correct/ resolve the discrepancy/problem indicated.) }\end{array}$ & $\begin{array}{l}14 . \\
\text { Hold } \\
\text { Point }\end{array}$ & $\begin{array}{l}\text { 15. Disposition (Provide justification if NOT } \\
\text { accepted.) }\end{array}$ & $\begin{array}{l}16 . \\
\text { Status }\end{array}$ \\
\hline & $\begin{array}{l}\text { Section 15300: } \\
\text { a) Para. 1.3.1: Delete. Quality program requirements } \\
\text { are already addressed by mandating installation, testing } \\
\text { and certification in accordance with NFPA } 13 \text {. } \\
\text { b) Para. 1.3.3: Delete. Section } 01405 \text { does not exist. } \\
\text { Misrepresented products are addressed in Section } 01400 \text {. } \\
\text { c) Para. 1.3.4: Delete reference to Section } 01415 \text { as } \\
\text { this section is not part of the Spec. }\end{array}$ & & $\begin{array}{l}\text { a) Paragraph has been deleted. } \\
\text { CLOSED: } \\
\text { b) Reference changed to Section } 01400 \text {. } \\
\text { CLOSED: } \\
\text { c) Reference to Section } 01415 \text { deleted, using } \\
\text { NFPA } 13 \text { reference only. } \\
\text { CLOSED: }\end{array}$ & $\begin{aligned} \text { All } \\
\text { Clsd. }\end{aligned}$ \\
\hline & $\begin{array}{l}\text { Section } 15400 \text { : } \\
\text { a) If ANSI B } 31.3 \text { is being invoked in this section, the } \\
\text { B31.3 Service Class needs to be identified. If B } 31.3 \text { is } \\
\text { not being invoked. delete it from the Article } 1.2 \text {. } \\
\text { b) Para. 3.5.1: "Maximum Temperature" numbers should } \\
\text { have "F" or "C". as appropriate, after the temperatures. }\end{array}$ & & $\begin{array}{l}\text { a) Added to paragraph } 2.1 .5 \text { and } 2.1 .7 \text {, see DCN W- } \\
441-008 . \\
\text { b) Added "F" } \\
\text { CLOSED: }\end{array}$ & $\begin{array}{l}\text { Clsd. } \\
\text { Clsd. }\end{array}$ \\
\hline & $\begin{array}{l}\text { Section 15406: Address the following: } \\
\text { a) B31.3 Piping Service Class } \\
\text { b) Welding/bonding requirements } \\
\text { c) Inspection requirements } \\
\text { d) Testing requirements }\end{array}$ & brf & Service class was added in DCN W-441-008. & Clsd. \\
\hline
\end{tabular}




\begin{tabular}{|l|l|l|}
\hline \multirow{2}{*}{ REVIEW COMMENT RECORD (RCR) } & $\begin{array}{l}\text { 1. Date } \\
10-11-96\end{array}$ & $\begin{array}{c}\text { Review No. } \\
\text { CVD-011-A }\end{array}$ \\
\cline { 2 - 4 } & $\begin{array}{r}\text { 3. Project No. } \\
\text { W-441 }\end{array}$ & $\begin{array}{c}\text { Page } \\
9 \text { of } 9\end{array}$ \\
\hline
\end{tabular}

Note 1: (Item 8.a.b.c) These changes need to be picked up on the OCN that addresses the specification changes identified in Bid Package. Addenda 2. Part IV, or on a separate DCN prepared in conjunction with the with the first one.

Hote 2. (Item 14) Response-should ddress

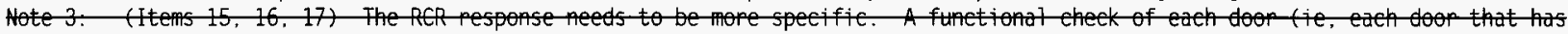

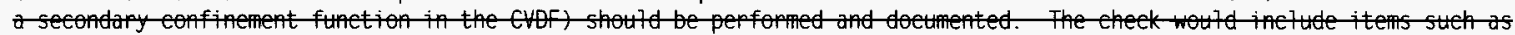

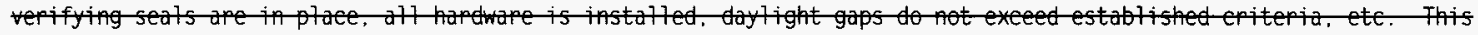

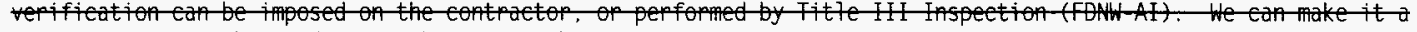

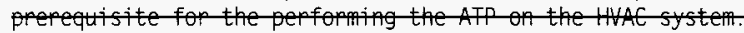

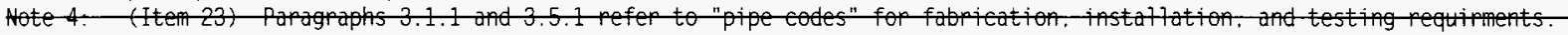

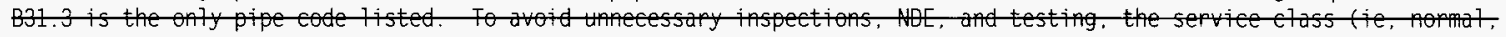

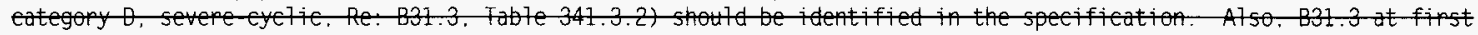

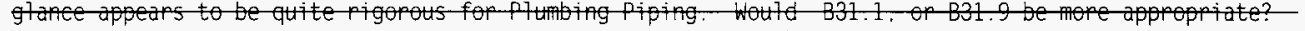

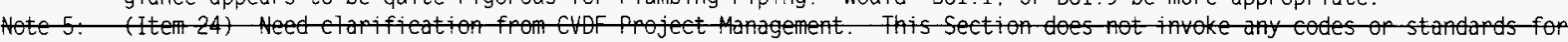

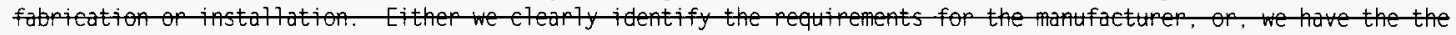

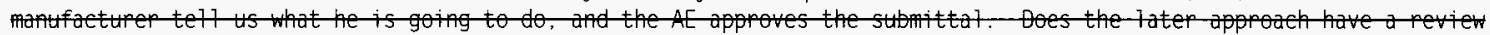
by site project personel to ensure the Project design input requirements are propery addressed? pleuse elarify 


\section{REVIEW COMMENT RECORD (RCR)}

\begin{tabular}{|l|l|}
\begin{tabular}{|l|} 
1. Date \\
$11-06-96$
\end{tabular} & $\begin{array}{l}\text { 2. Review No. } \\
\text { CVD-011-B }\end{array}$ \\
\hline $\begin{array}{c}\text { 3. Project No. } \\
\text { W-441 }\end{array}$ & 4. Page $\quad 1$ of 4 \\
\hline
\end{tabular}

\begin{tabular}{|l|l|l|l|l|}
\hline 5. Document Number(s)/Title(s) & $\begin{array}{l}\text { 6. Program/Project/ } \\
\text { Building Number }\end{array}$ & 7. Reviewer & 8. Organization/Group & 9. Location/Phone \\
\hline $\begin{array}{l}\text { Construction Spec. W-441-C1, 90\% Review, } \\
\text { Sept./October 1996. }\end{array}$ & $\begin{array}{l}\text { Project W-441 } \\
\text { Bldg. 142K }\end{array}$ & Brian Fillion & SNF Project QA \\
\hline
\end{tabular}

17. Comment Submittal Approval:

Organization Manager (Optional)
10. Agreement with indicated comment disposition(s)

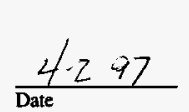

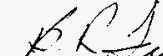

Kerieneren Reviewer/Point of Contact

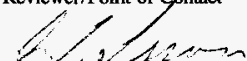

Auror/Originator
11. CLOSED

4.14 .97

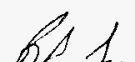

$4 \times-142$ Reviewer/Point of Contact

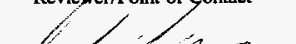

Anthor/Originator

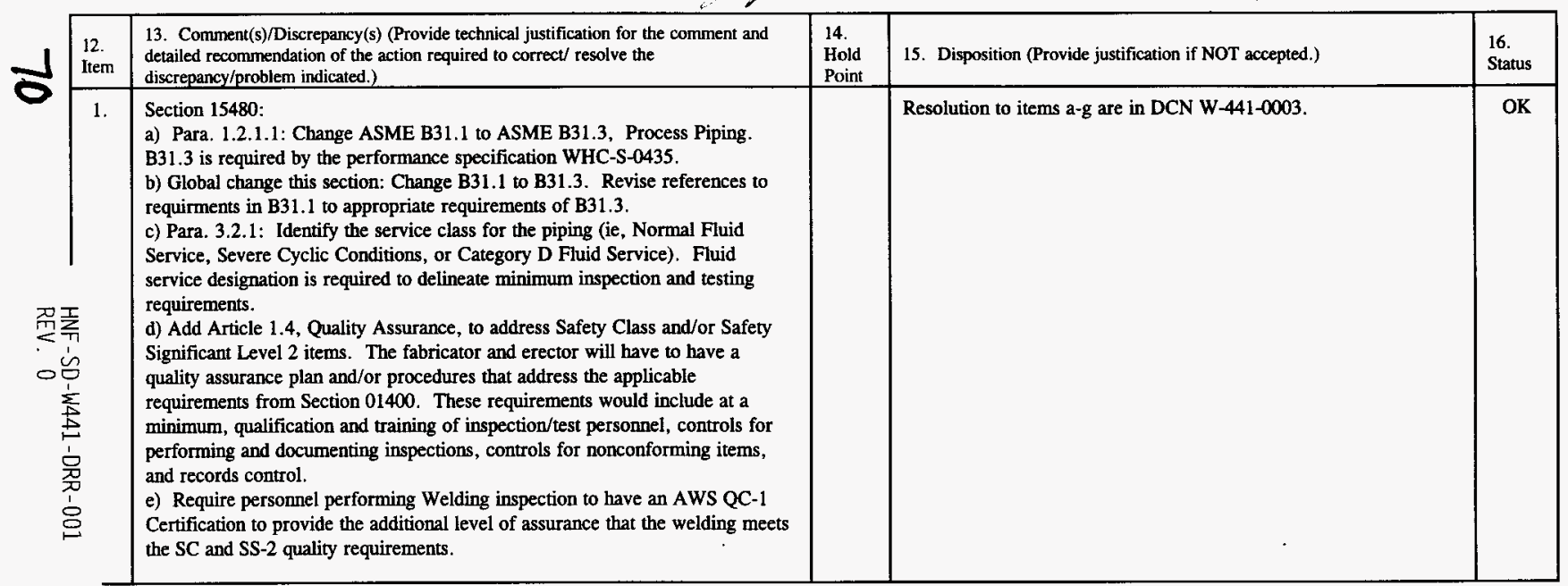




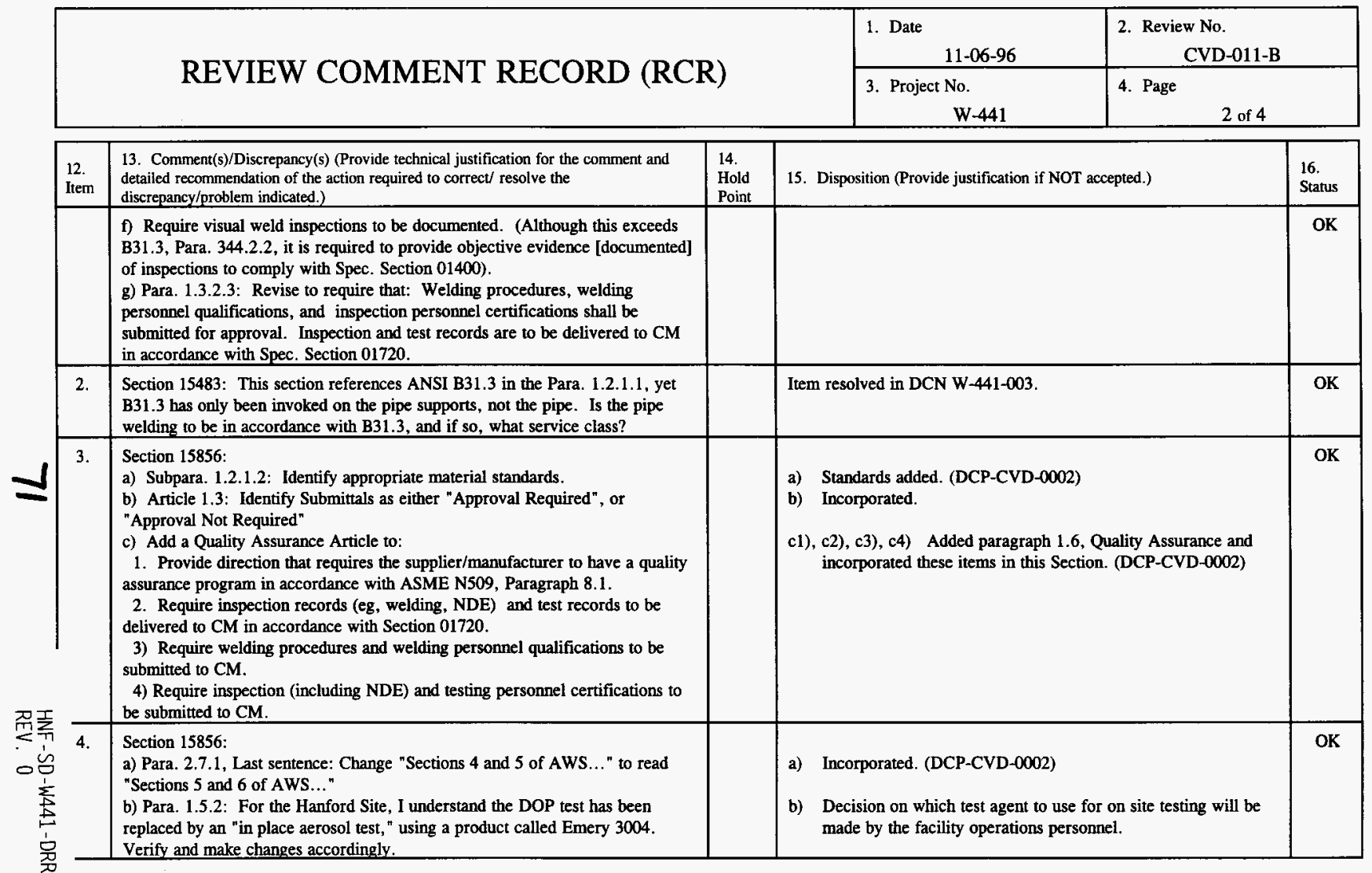




\begin{tabular}{|l|l|l|}
\hline \multirow{2}{*}{ REVIEW COMMENT RECORD (RCR) } & $\begin{array}{l}\text { 2. Date Review No. } \\
\text { CVD-011-B }\end{array}$ \\
\cline { 2 - 4 } & $\begin{array}{c}\text { 3. Project No. } \\
\text { W-441 }\end{array}$ & $\begin{array}{c}\text { 4. Page } \\
3 \text { of } 4\end{array}$ \\
\hline
\end{tabular}

\begin{tabular}{|l|l|l}
\hline 12. & 13. Comment(s)/Discrepancy(s) (Provide technical justification for the comment and
\end{tabular} Item detailed recommendation of the action required to correct/ resolve the

discrepancy/problem indicated.

5. Section 15890: See Note below:

a) Para. 1.3: Clarify purpose of submittals, i,ei, For Approval, Not For Approval.

b) Para. 1.6: Require a QA Program or procedures that address inspection personnel certifications, inspection controls, and inspection records.

c) Para. 1.3.5: To what welding code are the welding procedures/qaulification test required to comply with? AWS D9.1 is in referenced in 1.2, but it is not invoked in the fabrication section. Is all welding supposed to be performed in accordance with AWS D9.1?

d) Part 3 - Execution: This section does not address welding inspection requirements. Is the welding supposed to inspected in accordance with AWS D9.1, Section 6?

e) Part 2 - Products: Identify the products that are Safety Significant - Quality Level - 2. (if any)

f) Para. 2.3.4: Does this para. cover Process Bay general exhaust, and if so, should the Process Bay general exhaust be stainless steel, not galvanized?

Note: It is unclear in this Section if all the work is Quality Level 2, Quality Level 3, or both.

6. Section 15910 :

a) 1.3 Submittals: Clarify if submittals are For Approval or Not For Approval.

b) Para. 1.5: QA program requirements for suppliers of Quality Level 2 products, and Level 2 inspection activities and inspection personnel qualifications need to be clarified.

c) Part 2 Products: Identify Safety Significant Quality Level 2 products.

d) Para. 2.8: Should isolation dampers $8102 \rightarrow 8502$, and $8203-8205$ be added here?

e) Identify Materials of construction. Are the products to be made of stainless steel, galvanized steel?

f) If products are welded, what welding Codes apply?

g) Should Pneumatically Controlled Dampers be added to subparagraph 1.1.1?

h) Para. 1.3.2: Specify exactly what you want submitted. "other information as required" is meaningless.
15. Disposition (Provide justification if NOT accepted.)

a) Incorporated. (DCP-CVD-0002)

b) Incorporated. (DCP-CVD-0002)

c) Covered in Paragraph 3.1.10.1.

d) Inspection covered in Paragraph 3.1.10.1

e) Included in Section 2.1.3. (DCP-CVD-0002)

f) General exhaust is galvanized and local exhaust is stainless. (Clarified in DCP-CVD-0002)

a) Incorporated.

b) Added Quality Assurance Paragraph 1.7. (DCP-CVD-0002)

c) Included in Paragraphs 2.4.2.1 and 2.8.1. (DCP-CVD-0002)

d) Agreed. (DCP-CVD-0002)

e) Incorporated. (DCP-CVD-0002)

f) ASME N509 invokes welding requirements.

g) Section rewritten. (DCP-CVD-0002)

h) Incorporated. (DCP-CVD-0002) 


\begin{tabular}{|l|l|l|}
\hline \multirow{2}{*}{ REVIEW COMMENT RECORD (RCR) } & $\begin{array}{l}\text { 1. Date Review No. } \\
\text { CVD-011-B }\end{array}$ \\
\cline { 2 - 3 } & $\begin{array}{c}\text { 3. Project No. } \\
\text { W-441 }\end{array}$ & $\begin{array}{c}\text { 4. Page } \\
4\end{array}$ \\
\hline
\end{tabular}

\begin{tabular}{|c|l|l|l|}
\hline $\begin{array}{l}\text { 12. } \\
\text { Item }\end{array}$ & $\begin{array}{l}\text { 13. Comment(s)/Discrepancy(s) (Provide technical justification for the comment and } \\
\text { detailed recommendation of the action required to correct/ resolve the } \\
\text { discrepancy/problem indicated.) }\end{array}$ & $\begin{array}{l}14 . \\
\text { Hold } \\
\text { Point }\end{array}$ & $\begin{array}{l}\text { 16. Disposition (Provide justification if NOT accepted.) } \\
\text { Status }\end{array}$ \\
\hline $\begin{array}{l}\text { I) Para. 1.3.3: Delete "where applicable". } \\
\text { j) Para. 1.3: Add submittals from para. 2.8.5. } \\
\text { k) Part 3.0- Execution: There are no inspections or tests for the products } \\
\text { identified in 1.1.1. There shall be documented inspections/test to verify the as } \\
\text { constructed Quality Level 2 products are suitable for the intended applications? }\end{array}$ & $\begin{array}{l}\text { i) Incorporated. (DCP-CVD-0002) } \\
\text { j) Incorporated. (DCP-CVD-0002) } \\
\text { k) Incorporated. (DCP-CVD-0002) }\end{array}$ \\
\hline 7. & $\begin{array}{l}\text { Section 15990: Address quality assurance program requirements for the TAB } \\
\text { Agency. }\end{array}$ & $\begin{array}{l}\text { Scope of work has been assigned to FDNW. QAP requirements } \\
\text { not required in this section. }\end{array}$ & OK \\
\hline 8. & $\begin{array}{l}\text { Sections 15510, 15535, 15540, 15681, 15682, 15781, 15790, 15855, 15856,..., } \\
\text { Article 1.3: Specify type of Submittal, ie, "For Approval", or "Not for } \\
\text { Approval." This is a global comment applicable to all spec. sections which } \\
\text { require submittals to be in accordance with Section 01300. }\end{array}$ & Incorporated. \\
\hline
\end{tabular}

\section{$\omega$}

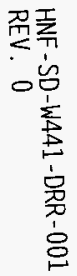




\begin{tabular}{|c|c|c|c|}
\hline 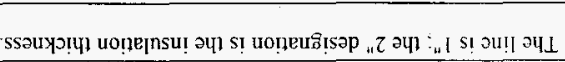 & & 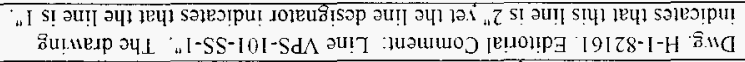 & 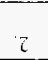 \\
\hline 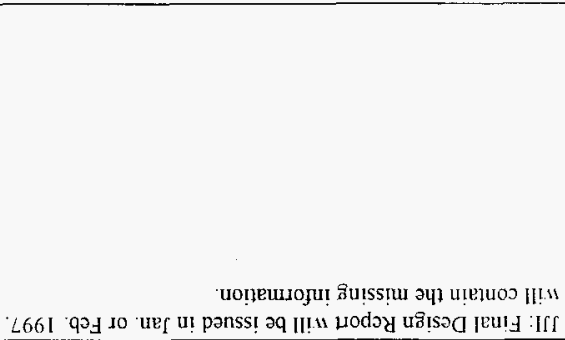 & & 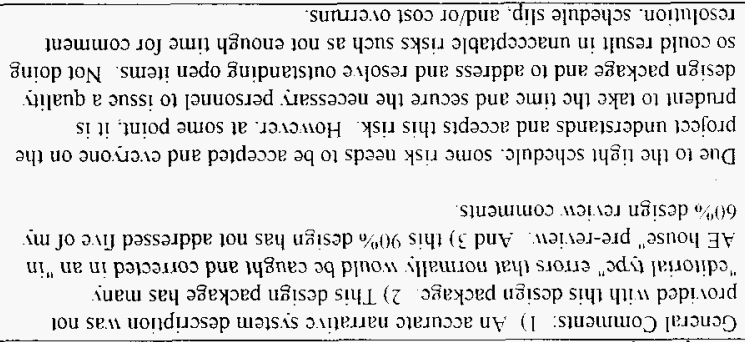 & I \\
\hline 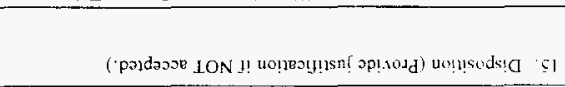 & 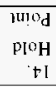 & 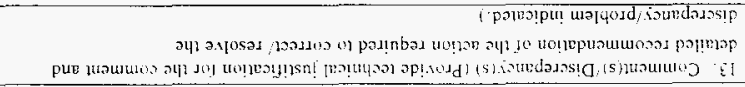 & 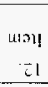 \\
\hline
\end{tabular}
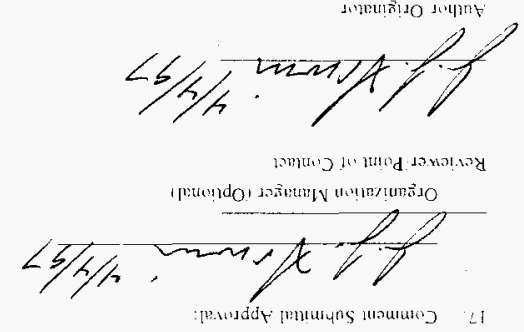

\begin{tabular}{|c|c|c|c|c|}
\hline $\begin{array}{l}t 6-\mathcal{E} L \mathcal{E} \\
t-90 \angle t\end{array}$ & Klojes reəjonN Had & 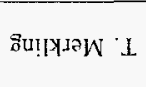 & 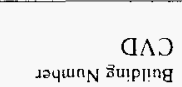 & 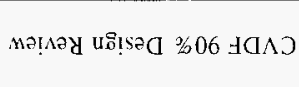 \\
\hline $918507 \cdot 6$ & dnoม/uo!̣pz! & Јอмวเیวу $L$ & 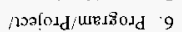 & 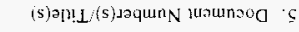 \\
\hline
\end{tabular}




\begin{tabular}{|c|c|c|}
\hline 3. & $\begin{array}{l}\text { Dwg. H-1-82161. Comment: Line VPS-101-SS-1 } 1^{\text {t: }} \text { The filter PV-F-111 } \\
\text { should be located as close to the MCO as is possible to prevent contamination } \\
\text { of sensitive instruments. and for ease of D\&D. Suggest placing the filter } \\
\text { between the MCO and pressure transmitter PT- } 1110 \text {. }\end{array}$ & $\begin{array}{l}\text { Cannot put HEPA in between } \mathrm{MCO} \text { and } \mathrm{GOV}-1 * 02 \text { because } \\
\text { surface area my cause pressure rise test to fail. JJI: there is } \\
\text { internal MCO HEPA to prevent skid contamination. }\end{array}$ \\
\hline 4. & $\begin{array}{l}\text { Dwg. H-1-82161. Comment: Line VPS-101-SS-1": Suggest installing a } \\
\text { back-flow preventer in this line to ensure unwanted air is not introduced into } \\
\text { the MCO. }\end{array}$ & $\begin{array}{l}\text { VPS-*(t)-SS- } 1 \text { " needs } 10 \text { be bidirectional in order to pull vac } \\
\text { during valic removal. Barring tine beak. attention has been } \\
\text { to O2 intrusion. JJI: Oxtgen levels in the MCO will be mo } \\
\text { bs the VPS RGA stStem. }\end{array}$ \\
\hline 5 & 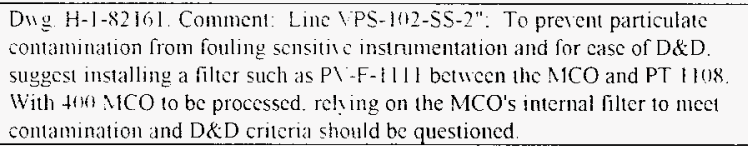 & 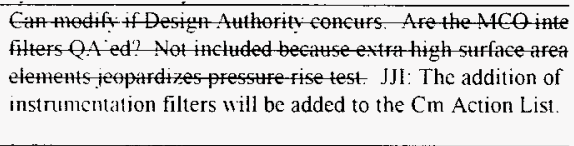 \\
\hline 6. & 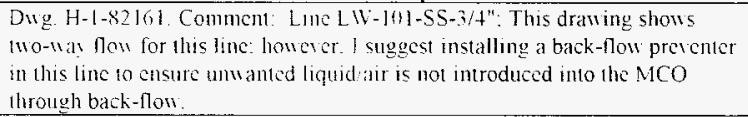 & $\begin{array}{l}\text { 2-was flow is in error. Flow is out only: Note checkralve } \\
\text { LW-CK }{ }^{*}+11 \text { on } 82163 \text {. }\end{array}$ \\
\hline- & $\begin{array}{l}\text { Dug H-1-82161. Editorial Comment: Line LW-101-SS-3/4" is listed as a } \\
34 \text {-jmeh line on this drawing and as a } 1 \text {-inch line on drawing } \mathrm{H}-1-82163\end{array}$ & Changed thank you. \\
\hline 8. & 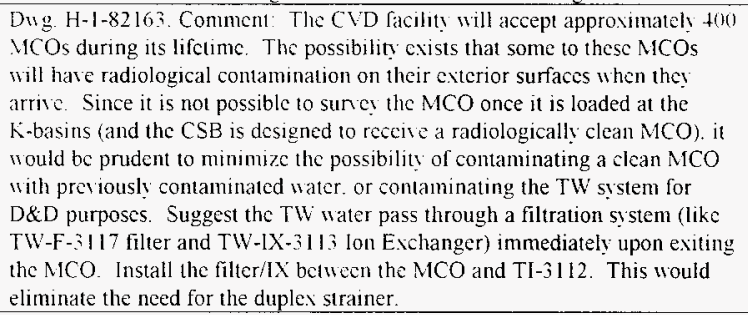 & $\begin{array}{l}\text { Design was to polish the tempered water. Equipment gets l } \\
\text { the required flows. If Design Authority concurs. then this w } \\
\text { have to be changed. The installed LX will see many passes } \\
\text { water during a run. } \\
\text { JII: Item added to CM Action List to investigate use of a } \\
\text { stb-micron filter in the TW system at the exit of the MCO/ } \\
\text { connection. }\end{array}$ \\
\hline ). & $\begin{array}{l}\text { Dwg H-1-82 I63: Editorial Comment: The drawing indicates that Line } \\
\text { LW-103-S5-1" is continued to drawing H-1-82227. yel this } 82227 \text { drawing is } \\
\text { for DI and PW. Dwg. H-1-82225 shows liquid waste lines; however. I could } \\
\text { not find LW-103-SS-1 on this drawing either. }\end{array}$ & Will be coordinated correctly in final issue. Thank you. \\
\hline 10. & $\begin{array}{l}\text { Dwg. H-1-82164: Editorial Comment: I was unable to find the plysical } \\
\text { location of TK } 4032 \text { or the filter (LW-F-4037) and lon Exchanger } \\
\text { (LW-IX-4038). A lav-out drawing would he helpful. Where are they located? }\end{array}$ & $\begin{array}{l}\text { Because of late change and process decision delay from WH } \\
\text { P\&ID was only } 90 \% \text { definition. }\end{array}$ \\
\hline
\end{tabular}




\begin{tabular}{|c|c|c|}
\hline 11. & 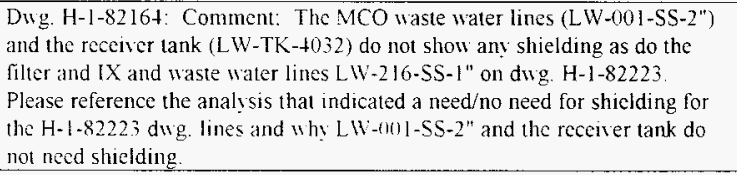 & See $\# 10$ above. Will probably require shielding. \\
\hline 12. & 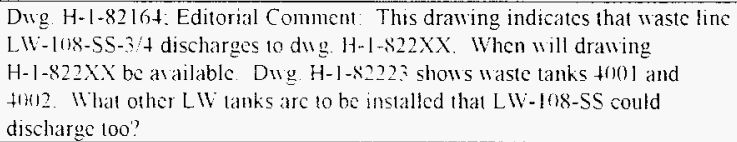 & $\begin{array}{l}822 \times X \text { returns to } 5000 \text { gallon waste tank. Will be correctly } \\
\text { integrated in final issue. }\end{array}$ \\
\hline 13 & 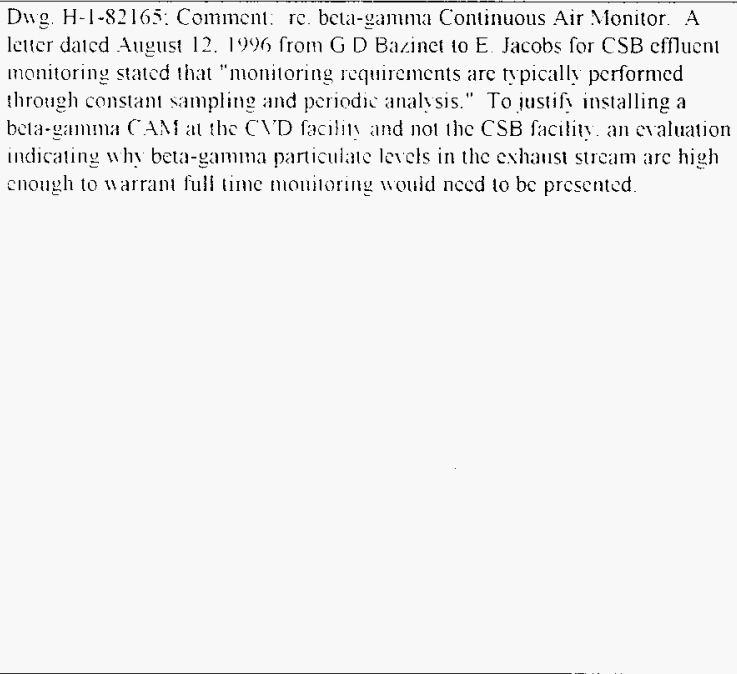 & 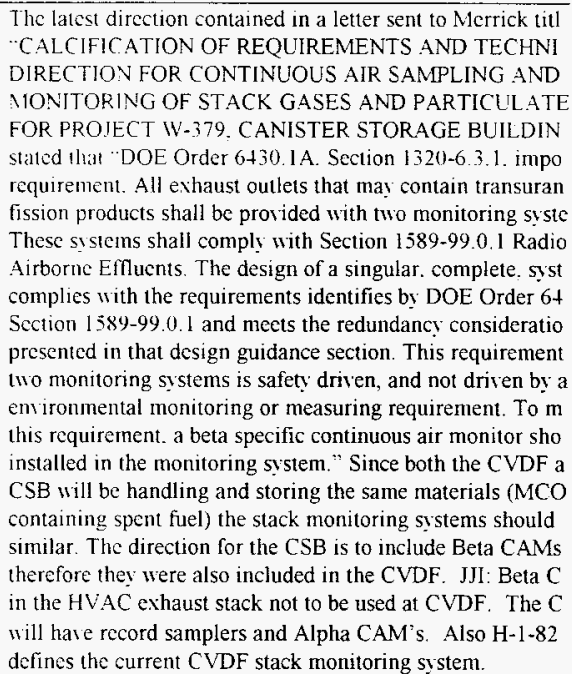 \\
\hline
\end{tabular}




\begin{tabular}{|c|c|c|}
\hline 14 & $\begin{array}{l}\text { Dwg. H-1-82165: Comment: Sample line SMP-001-SS-1 } 1 / 2 \text { splits down to } \\
\text { t-inch prior to reaching the sample filler and lodine cartridge. Provide the } \\
\text { analysis that indicates that a } / \text { inch line provides the diameter necessan to } \\
\text { cnsure that a representative particulate sample is delivered to the filter. }\end{array}$ & $\begin{array}{l}\text { Air flow rates of } 60 \text { liters per minute in a } 1 / 2 \text { inch line were } \\
\text { calculated at } 2+0 \text { feet per minule. At this velocity particulat } \\
\text { precipitation will not occur. In addition, the sampling lines } \\
\text { heat traced to prevent cooling of the sample flowing to the fi } \\
\text { traps. and CAMs. JJI: The system design calculations will } \\
\text { be independently verified during Title III design, this item a } \\
\text { to CM Action List. The air sampling system will be provide } \\
\text { Nuclear Research Corp. as a sole source purchase. }\end{array}$ \\
\hline 15 & 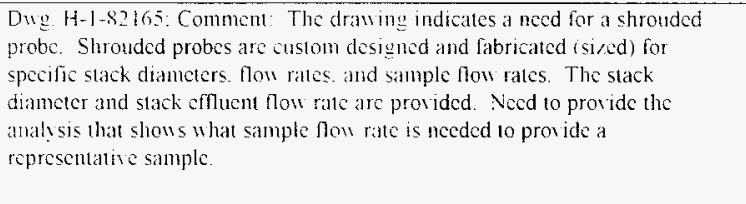 & $\begin{array}{l}\text { As indicated in comment number } 16 \text { the shrouded probes ar } \\
\text { normalis Texas A\&N designs. The actual design of the shr } \\
\text { probe thas been left to the manufacturer of the stack spool pi } \\
\text { and monitoring ssicm. It was assumed that the selected } \\
\text { mamufacturer would contact Texas A\&M and its associated } \\
\text { mamufacturing shops in order to obtain the appropriatc shro } \\
\text { probes. }\end{array}$ \\
\hline 16 & $\begin{array}{l}\text { Dig. H-1-82165. Gencral Comment Shrouded probes ate not off the shelf } \\
\text { items. Normally. Texas A\&M designs the probe and an independent College } \\
\text { Statlion. Texas shop fabricates the probe. These effons will need a feu } \\
\text { months lead time for design. fabrication. installation and testing. This needs } \\
\text { to be considered in the schedule. and the probe size and location needs } 10 \text { be } \\
\text { considered for effluent stack construction. }\end{array}$ & $\begin{array}{l}\text { Agred. this information should be obtained by the supplier } \\
\text { monitoring sistem and passed to the project coordinator for } \\
\text { jncorporation into the appropriate schedules. }\end{array}$ \\
\hline 17 & $\begin{array}{l}\text { Dwg. H-1-\$2165: Editorial Comment: The drawing indicates a "Calibration } \\
\text { Port" for the shrouded probe. There is not a need for calibration of Shrouded } \\
\text { probes: howerer. an "inspection port" would be nice to ensure the probe } \\
\text { remains free from dir or debris build-up on its leading edge. }\end{array}$ & Agrecd. The ports may be used for calibration or inspection. \\
\hline 18 & $\begin{array}{l}\text { Dwg. H-1-\$2170/82172: Editorial Comment This drawing shows a Liquid } \\
\text { Waste Process Tank LW-TK- } 111 \text {. I could not find this tank on any of the } \\
\text { P\&ID drawings. Lines LW-102 and LW-103 are shown on drawings } \\
\text { H-1- } 82181 \text { and H-1-82163 but these lines lead to a dead end (see comment 9). } \\
\text { Where do they go? }\end{array}$ & Refer to $\# 12$ above. Will be correctly coordinated for final $\mathrm{i}$ \\
\hline 19) & $\begin{array}{l}\text { Dwg. H-1-82223. Editorial Comment. Shiclded lines LW-216-SS-1". } 316 \text {. } \\
+16 . \text { and } 516 \text {. The drawing indicates that these } 1 \text {-inch lines come from dwg. } \\
\mathrm{H}-1-82164 \text {. however. the liquid waste line from dwg. H-1-82 } 164 \text { is a } 3 / 4-i n c h \\
\text { line labeled LW-108-SS-3/4" going to H-1-822XX. Please clarify. }\end{array}$ & $\begin{array}{l}\text { "Shielding" is removed from P\&ID. I" - SChl } 160 \text { piping is } \\
\text { adequate for shielding. } \\
\text { Refer to } \$ 12 \text { above. Will be correctly coordinated for final } \mathrm{i}\end{array}$ \\
\hline
\end{tabular}




\begin{tabular}{|c|c|c|}
\hline 20. & 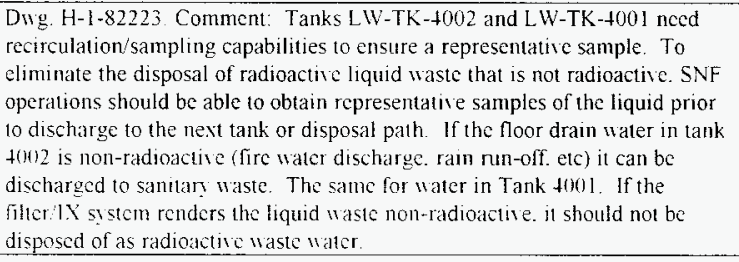 & $\begin{array}{l}\text { Sample valve is in LW-TK-4001. Pump suction moved to } p \\
\text { discharge. Recirculation is possible with this system. Man } \\
\text { provided in } L W-T K-4002 \text { for sampling and drain valve to } d \\
\text { retention basin if clean. JJI: The addition of radiation moni } \\
\text { of TK- }+002 \text { has been added to the CM Action List. }\end{array}$ \\
\hline 21 & 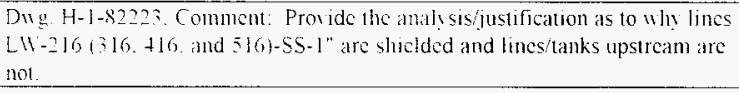 & See response $10 \mathrm{hcm} 19$ above. \\
\hline 22 & 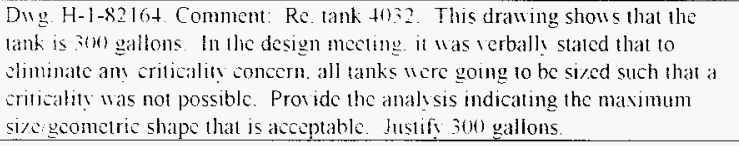 & $\begin{array}{l}\text { Tank max ID is } 2+" \text { per WHC. } 300 \text { gallon provides } 100 \text { gal } \\
\text { heel and } 200 \text { gallon for MCO drain safety margin. } 2 t^{\prime \prime} \text { Max } \\
\text { will roree less volume to keep height reasonable. }\end{array}$ \\
\hline 23 & 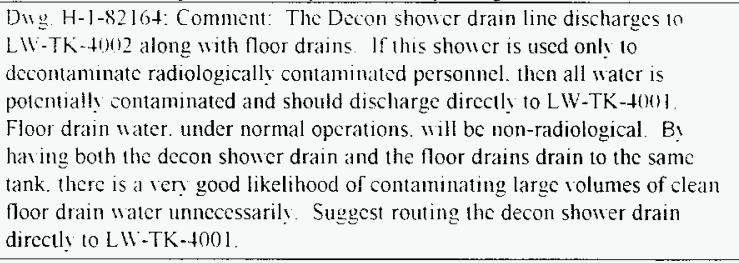 & $\begin{array}{l}\text { Floor drains will not be used under normal operations. All } \\
\text { to LW-TK-4002 are potentially contaminated. If collected } \\
\text { is not contaminated. then it can be drained to the retention b } \\
\text { where it will evaporate. The total volume of water will be s } \\
\text { in any case with the exception of a fire event. JJI: The addit } \\
\text { radiation monitoring of TK- }+002 \text { has been added to the C } \\
\text { Action Lisl. The use of a self contained safety shower such } \\
\text { Haz Nat Medical Associates "Disposacon " model. } \\
\text { 1-8010-462-4002. has been added to the CM Action List. }\end{array}$ \\
\hline
\end{tabular}




\section{REVIEW COMMENT RECORD (RCR)}

\begin{tabular}{|l|l|}
\hline $\begin{array}{l}\text { 1. Date } 10-03-96 \\
\text { 3. Project No. } \\
\text { W-441 }\end{array}$ & 4. Page \\
\hline
\end{tabular}

\section{Document Number(s)/Title(s)}

Cold Vacuum Drying Facility $90 \%$ Design Review, WHC-SD-W-441-CI-ATP-004

17. Comment Submittal Approval:

Organization Manager (Optional)

\begin{tabular}{l|l}
$\begin{array}{l}\text { 6. Program/Project/ } \\
\text { Building Number } \\
\text { CVD/W-441/142K }\end{array}$ & 7. Reviewer \\
\end{tabular}

10. Agreement with indicated commenydisposition(s)

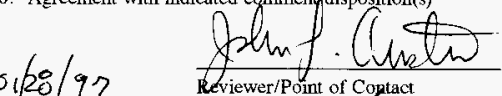
Date

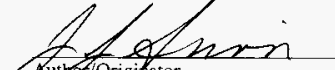

\section{Organization/Group \\ SNF PROJECTS/ STARTUP}

\section{Location/Phone}

TCPC/373-6439
11. CLOSED

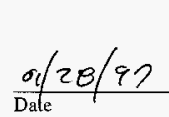

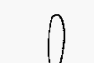

ก

1

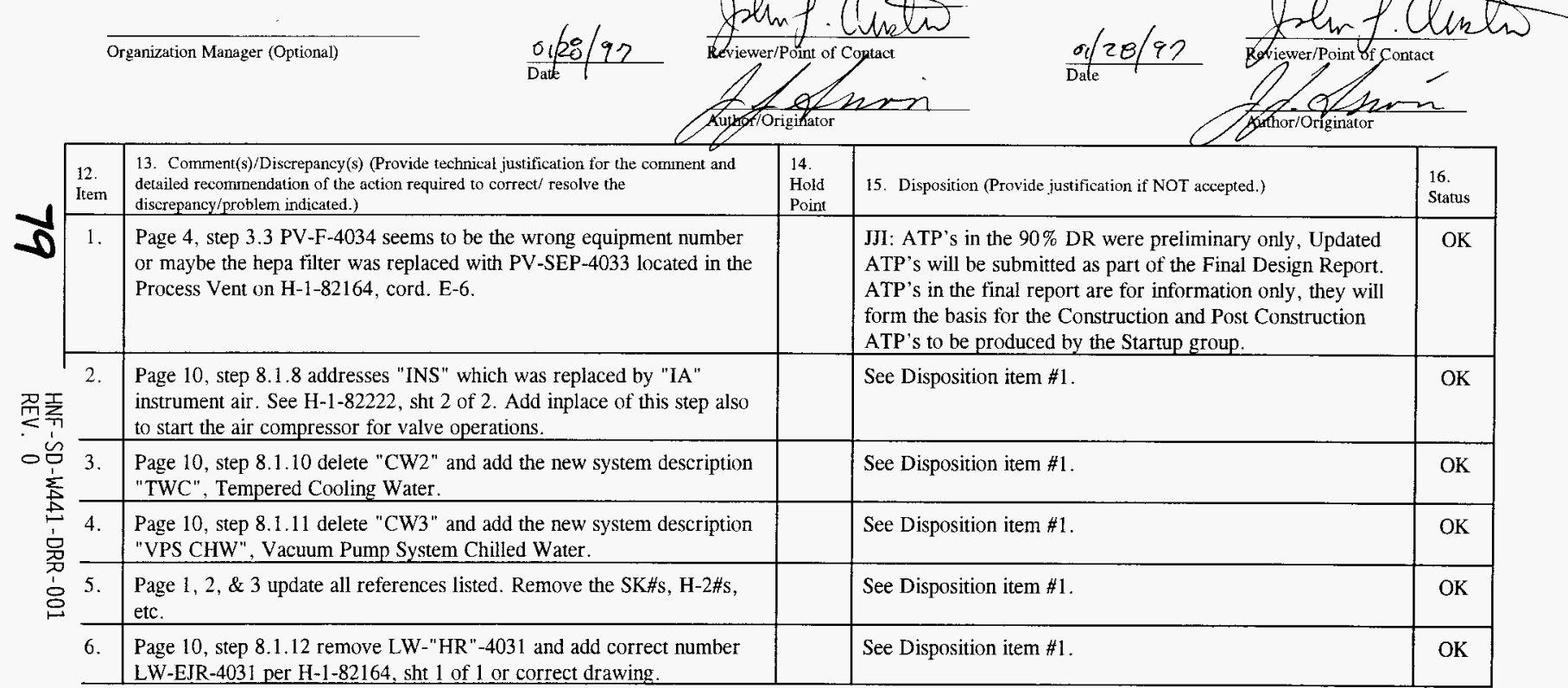




\begin{tabular}{|l|l|l|l|}
\hline \multirow{2}{*}{ REVIEW COMMENT RECORD (RCR) } & 1. Date & $10-03-96$ & Review No. \\
\cline { 2 - 4 } & $\begin{array}{c}\text { 3. Project No. } \\
\text { W-441 }\end{array}$ & $\begin{array}{c}4 . \text { Page } \\
2\end{array}$ \\
\hline
\end{tabular}

\begin{tabular}{|c|l|l|l|}
\hline $\begin{array}{l}\text { 12. } \\
\text { liem }\end{array}$ & $\begin{array}{l}\text { 13. Comment(s)/Discrepancy(s) (Provide technical justification for the comment and } \\
\text { detailed recommendation of the action required to correct/ resolve the } \\
\text { discrepancy/problem indicated.) }\end{array}$ & $\begin{array}{l}\text { 14. } \\
\text { Hold } \\
\text { Point }\end{array}$ & $\begin{array}{l}\text { 15. Disposition (Provide justification it NOT accepted.) } \\
\text { Status }\end{array}$ \\
\hline 7. & $\begin{array}{l}\text { Page 12, step 8.1.20 remove PDISH-"4040" and add correct number } \\
\text { PDISH-"4046" per H-1-82164, sht 1 of } 1 \text { or correct drawing. }\end{array}$ & & See Disposition item \#1. \\
\hline 8. & $\begin{array}{l}\text { Page 14, Initial Valve Lineup remove "CW2" and "CW3" at system and } \\
\text { tag number and add "TWC" and "VPSCHW" respectively. }\end{array}$ & See Disposition item \#1. \\
\hline 9. & $\begin{array}{l}\text { Page 16, Initial Valve Lineup remove "INS" at system and tag number } \\
\text { and add "IA" per H-1-82222. }\end{array}$ & See Disposition item \#1. \\
\hline 10. & $\begin{array}{l}\text { Page 19, Indicator List correct list for the new system descriptions. } \\
\text { Example: "INS" to "IA". }\end{array}$ & See Disposition item \#1. \\
\hline 11. & $\begin{array}{l}\text { Page 21, Data Form correct list for the new equipment numbers. } \\
\text { Examples: PDISH-"4040" to "PDISH-4046" (See item \# 7 above). }\end{array}$ & OK \\
\hline
\end{tabular}




\begin{tabular}{|l|l|l|}
\hline \multirow{2}{*}{ REVIEW COMMENT RECORD (RCR) } & 1. Date & 2. Review No. \\
\cline { 2 - 3 } & $\begin{array}{c}\text { 3. Project No. } \\
\text { W-441-C1 }\end{array}$ & $\begin{array}{l}\text { 4. Page } \\
\text { 1 of } 2\end{array}$ \\
\hline
\end{tabular}

\begin{tabular}{|l|l|l|l|l|}
\hline 5. Document Number(s)/Title(s) & $\begin{array}{l}\text { 6. Program/Project/ } \\
\text { Building Number } \\
\text { SNF/CVDF/142K }\end{array}$ & 7. Reviewer & 8. Organization/Group & 9. Location/Phone \\
$\begin{array}{l}\text { Cold Vacuum Drying Facility 90\% Design } \\
\text { Review }\end{array}$ & Oustin/LATA & Operations/startup \\
\hline
\end{tabular}

17. Comment Submittal Approval:

Organization Manager (Optional)
10. Agreement with indicated/cpmment digposition(s)

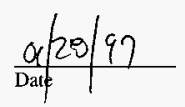

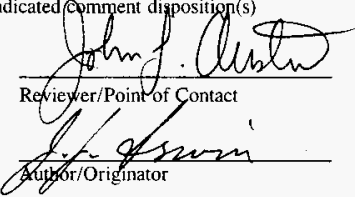
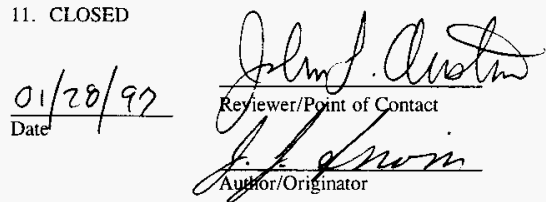

\begin{tabular}{|c|c|c|c|c|c|}
\hline & $\begin{array}{l}12 . \\
\text { Item }\end{array}$ & $\begin{array}{l}\text { 13. Comment(s)/Discrepancy(s) (Provide technical justification for the comment and } \\
\text { detailed recommendation of the action required to correct/ resolve the } \\
\text { discrepancy/problem indicated.) }\end{array}$ & $\begin{array}{l}14 . \\
\text { Hold } \\
\text { Point }\end{array}$ & 15. Disposition (Provide justification if NOT accepted.) & $\begin{array}{l}16 . \\
\text { Status }\end{array}$ \\
\hline 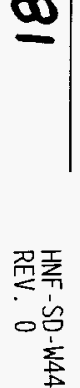 & 1. & $\begin{array}{l}\text { Add valve numbers to P\&ID H-1-82208 "Chilled Water System" and } \\
\text { valve numbers for the supply valves for the } 4 \text { HVAC Exhaust Fans on } \\
\text { drawing H-1-82206. } \\
\text { Note: } \\
\text { Check all P\&IDs to verify that all valves and equipment are properly } \\
\text { numbered. These are the most important drawings for the CVD facility } \\
\text { and for all the SNF Projects. This is a "must" for hanging LOCK \& } \\
\text { TAGs; for writing OTPs \& Pre-operational Tests with their valve } \\
\text { lineups; for hanging our blue tags for test boundries; for surveillance } \\
\text { and preventive maintenance programs \& procedures; for implementing } \\
\text { our labeling program \& procedures and to establish boundries for } \\
\text { turnover or partial turnovers of systems and components. }\end{array}$ & & $\begin{array}{l}\text { Will do during final QA. JJI: Additional items for } \mathrm{H}-1-82208 \\
\text { added to CM Action List. }\end{array}$ & OK \\
\hline $\begin{array}{l}\overline{1} \\
\text { 유र } \\
0 \\
0\end{array}$ & 2. & $\begin{array}{l}\text { Remove "CW2" and add "TWC" at } \mathrm{HX}-7051 \text { and remove the drawing } \\
\text { referenced "H-1-82228" and add "H-1-82224" on drawing H-1-82208, } \\
\text { B-4. }\end{array}$ & & Incorporated. & $\mathrm{OK}$ \\
\hline
\end{tabular}




\begin{tabular}{|c|l|l|}
\hline \multirow{2}{*}{ REVIEW COMMENT RECORD (RCR) } & $\begin{array}{l}\text { 1. Date } \\
\text { 10/3/96 }\end{array}$ & \multicolumn{2}{|l|}{ Review No. } \\
\cline { 2 - 3 } & $\begin{array}{c}\text { 3. Project No. } \\
\text { W-441-C1 }\end{array}$ & $\begin{array}{l}\text { 4. Page } \\
2 \text { of } 2\end{array}$ \\
\hline
\end{tabular}

\begin{tabular}{|c|l|l|l|}
\hline $\begin{array}{l}\text { 12. } \\
\text { Item }\end{array}$ & $\begin{array}{l}\text { 13. Comment(s)/Discrepancy(s) (Provide technical justification for the comment and } \\
\text { detailed recommendation of the action required to correct/ resolve the } \\
\text { discrepancy/problem indicated.) }\end{array}$ & $\begin{array}{l}\text { 14. } \\
\text { Hold } \\
\text { Point }\end{array}$ & $\begin{array}{l}\text { 15. Disposition (Provide justification if NoT accepted.) } \\
\text { Status }\end{array}$ \\
\hline 3. & $\begin{array}{l}\text { All P\&IDs should be grouped together and numbered sequentially just } \\
\text { behind the Legend, Notes and Definitions, presently dwg\# H-1-82160. } \\
\text { Examples are the new HVAC drawings H-1-82204 thru H-1-82208. We } \\
\text { now have three set of drawings (See H-1-82090, sht } 1 \text { thru 3) with } \\
\text { P\&IDs in each set and some are duplicated. }\end{array}$ & $\begin{array}{l}\text { This was done because there are 3 procurement packages. } \\
\text { Facility and process skids are separate packages. P\&ID's for } \\
\text { skid match up to non-sequential facility drawings. If design } \\
\text { authority requires sequential \#'s, then we will modify } \\
\text { required drawings. }\end{array}$ & $\begin{array}{l}\text { OK } \\
\text { 4. }\end{array}$ \\
$\begin{array}{l}\text { Why are the HVAC system drawings H-1-82204 thru H-1-82208 lighter } \\
\text { shaded at the system components and equipment? Will this be a problem } \\
\text { later in making copies of these drawings? }\end{array}$ & Plotted incorrectly. Will be corrected. \\
\hline 5. & $\begin{array}{l}\text { Add full piping numbers for "CW-XXX-XX-2 1/2" supply and "CW- } \\
\text { XXX-XX-2 1/2" return on drawing H-1-82224, E-2. }\end{array}$ & OJI: This item added to CM Action List. \\
\hline
\end{tabular}




\begin{tabular}{|c|c|c|}
\hline \multirow{2}{*}{ REVIEW COMMENT RECORD (RCR) } & $\begin{array}{l}\text { 1. Date } \\
10-03-96 \\
\end{array}$ & 2. Review No. \\
\hline & $\begin{array}{l}\text { 3. Project No. } \\
\text { W-441 }\end{array}$ & 4. Page \\
\hline
\end{tabular}

\begin{tabular}{|l|l|l|l|l|}
\hline 5. Document Number(s)/Title(s) & $\begin{array}{l}\text { 6. Program/Project/ } \\
\text { Building Number } \\
\text { CVD/W-441 }\end{array}$ & 7. Reviewer & 8. Organization/Group \\
$\begin{array}{l}\text { Cold Vacuum Drying Facility 90\% Design } \\
\text { Review, H-1-82222, sht. 2 of 2 }\end{array}$ & John L. Austin & $\begin{array}{l}\text { SNF } \\
\text { PROJECTS/STARTUP }\end{array}$ & TCPC/373-6439 \\
\hline
\end{tabular}

17. Comment Submittal Approval:

Organization Manager (Optional)

10. Agreement with indicated commenpdisposition(s)
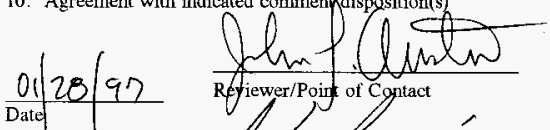

11. CLOSED
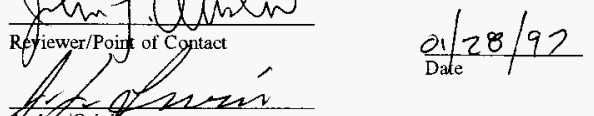

Aunor/Orighator

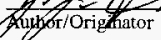

Author/Origh

13. Comment(s)/Discrepancy(s) (Provide technical justification for the comment and detailed recommendation of the action required to correct/ resolve the discrepancy/problem indicated.)
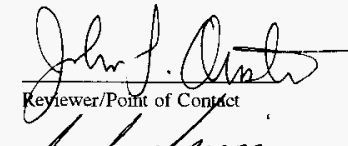

\begin{tabular}{|l|l|l|c|}
\hline $\begin{array}{l}14 . \\
\text { Hold } \\
\text { Point }\end{array}$ & 15. Disposition (Provide justification if NOT accepted.) & $\begin{array}{l}16 . \\
\text { Status }\end{array}$ \\
\hline d & & Added. & OK \\
\hline A & & Added. & OK \\
\hline
\end{tabular}
the full equipment ID numbers for the air compressor, receiver and dryer at a minimum.

2. The letters "P\&ID" needs to be added to the title block for the new CA/IA drawing sht. 2 of 2 to match sht. 1 of 2 .

\section{2}




\begin{tabular}{|l|l|l|}
\hline \multirow{2}{*}{ REVIEW COMMENT RECORD (RCR) } & 1. Date & \multicolumn{1}{|c|}{$10-03-96$} \\
\cline { 2 - 3 } & $\begin{array}{c}\text { 3. Project No. } \\
\text { W-441 }\end{array}$ & 4. Page \\
\hline
\end{tabular}

\begin{tabular}{|l|l|l|l|}
\hline 5. Document Number(s)/Title(s) & $\begin{array}{l}\text { 6. Program/Project/ } \\
\text { Building Number } \\
\text { CVD/W-441 }\end{array}$ & 7. Reviewer & John L. Austin \\
$\begin{array}{l}\text { Cold Vacuum Drying Facility 90\% Design } \\
\text { Review, H-1-82163, sht. 1 of 1 }\end{array}$ & 9rganization/Group & SNF PROJECT/STARTUP & TCPC/373-6439 \\
\hline
\end{tabular}

17. Comment Submittal Approval:

Organization Manager (Optional)
10. Agreement with indicated corpanent dpposition(s)

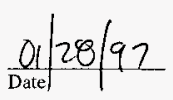

11. CLOSED

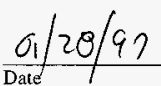

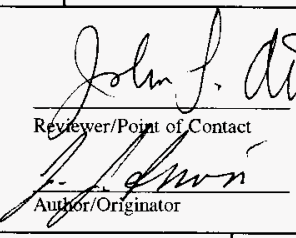

12. 13. Comment(s)/Discrepancy(s) (Provide technical justification for the comment and detailed recommendation of the action required to correct/ resolve the discrepancy/problem indicated.)

This drawing references "TWC-101-SS-1 1/2" (cord. E-7) and "TWC102-SS-1 1/2" (cord. F-2) which are the inlet and out cooling piping for heat exchanger TW-CLR-3110. These piping are capped on H-1-82224, cords. F-8 and D-8. Two other lines not capped will need to be picked, like TWC-201-SS-1 1/2" and TWC-202-SS-1 1/2". This drawing also references drawings on these lines as "H-1-82227", cord E-8 and "H-182228 ", cord. F-1. These are Mechanical Utilities drawings. P\&IDs should tie P\&IDs together, not to mech. utilities drawings. The drawing should be changed to H-1-82224 at both places. Again there is no flow

名 with the P\&IDs. Every time we make a change in the P\&IDS, all the drawings are not changed or tied together correctly like P\&IDs should.

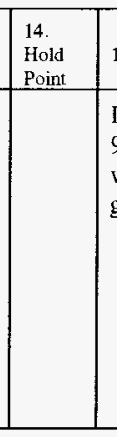




\begin{tabular}{|c|c|c|}
\hline . & $\begin{array}{l}\text { 1. Date } \\
10-10-96\end{array}$ & 2. Review No. \\
\hline KEVIEW COMVIENT KECOKD (KC) & $\begin{array}{l}\text { 3. Project No. } \\
\text { W-441 }\end{array}$ & 1 of 4 \\
\hline
\end{tabular}

\begin{tabular}{|l|l|l|l|l|}
\hline $\begin{array}{l}\text { 5. Document Number(s)/Title(s) } \\
\begin{array}{l}\text { CVDF 90\% Design Review (DWG \#s H-1-82161 } \\
\text { thru H-1-82164 }\end{array}\end{array}$ & $\begin{array}{l}\text { 6. Program/Project/ } \\
\text { Building Number } \\
\text { SNFP/CVDF/142K }\end{array}$ & 7. Reviewer & 8. Organization/Group \\
John L. Austin & SNF ROJECTS/ STARTUP & TCPC/373-6439 \\
\hline
\end{tabular}

\section{Comment Submittal Approval:}

Organization Manager (Optional)
10. Agreement with indicated comment dispositpn(s)

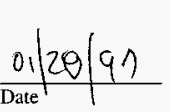

icated coinge
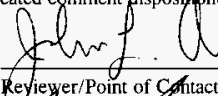
Reyieyer/Foint of Cfotact

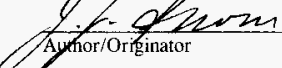

11. CLOSED

\begin{tabular}{|c|c|c|c|c|}
\hline $\begin{array}{l}12 . \\
\text { Iten }\end{array}$ & $\begin{array}{l}\text { 13. Comment(s)/Discrepancy(s) (Provide technical justification for the comment and } \\
\text { detailed recommendation of the action required to correct/ resolve the } \\
\text { discrepancy/problem indicated.) }\end{array}$ & $\begin{array}{l}14 . \\
\text { Hold } \\
\text { Point }\end{array}$ & 15. Disposition (Provide justification if NOT accepted.) & $\begin{array}{l}16 \\
\text { Status }\end{array}$ \\
\hline 1 & $\begin{array}{l}\text { Drawing \# H-1-82161 } \\
\text { 1. Change "INS" to "IA" at INS-QD-116 at cord. C-8. } \\
\text { 2.Change bottom (TW Supply) piping ID number TW-101-SS-1 } 1 / 2 \text { " to } \\
\text { TW-201-SS-1 } 1 / 2 \text { " at cord. A-1. } \\
\text { 3.Change top (TW Return) piping ID number TW- } 102-S S-11 / 2 " \text { to } \\
\text { TW-202-SS-1 } 1 / 2 " \text { at cord. B-1. } \\
\text { 4.Change piping ID number VPS-102-SS-2" to VPS-202-SS-2" at cord. } \\
\text { D-2. } \\
\text { 5.Change piping ID number VPS-101-SS-2" to VPS-201-SS-2" at cord. } \\
\text { E-2. } \\
\text { 6.Change piping ID number LW-101-SS-3/4" to LW-201-SS-3/4" at } \\
\text { cord. E-2. } \\
\text { 7.Change piping ID number DI-101-SS-1" to DI-201-SS-1" at cord. E- } \\
\text { 2. } \\
\text { 8.Change drawing number H-1-82226 (does not have DI) to H-1-82222, } \\
\text { sht } 1 \text { of } 2 \text {, cord E-4 at cord. E-1 of this drawing. }\end{array}$ & & $\begin{array}{l}\text { 1. Done. } \\
\text { 2. Change using wild card }(*) \text { for bays } 2-5 \text {. } \\
\text { 3. Change using wild card }(*) \text { for bays } 2-5 \text {. } \\
\text { 4. Change using wild card }(*) \text { for bays } 2-5 \text {. } \\
\text { 5. Change using wild card }(*) \text { for bays } 2-5 \text {. } \\
\text { 6. Change using wild card }(*) \text { for bays } 2-5 \text {. } \\
\text { 7. Change using wild card }(*) \text { for bays } 2-5 \text {. } \\
\text { 8. Done. }\end{array}$ & OK \\
\hline
\end{tabular}




\begin{tabular}{|c|l|l|}
\hline \multirow{2}{*}{ REVIEW COMMENT RECORD (RCR) } & $\begin{array}{l}\text { 1. Date } \\
10-10-96\end{array}$ & \multicolumn{2}{|l|}{ Review No. } \\
\cline { 2 - 3 } & $\begin{array}{c}\text { 3. Project No. } \\
\text { W-441 }\end{array}$ & $\begin{array}{l}\text { 4. Page } \\
2 \text { of } 4\end{array}$ \\
\hline
\end{tabular}

\begin{tabular}{|c|c|c|c|c|}
\hline $\begin{array}{l}12 . \\
\text { Item }\end{array}$ & $\begin{array}{l}\text { 13. Comment(s)/Discrepancy(s) (Provide technical justification for the conment and } \\
\text { detailed recommendation of the action required to correct/ resolve the } \\
\text { discrepancy/problem indicated.) }\end{array}$ & $\begin{array}{l}14 . \\
\text { Hold } \\
\text { Point }\end{array}$ & 15. Disposition (Provide justification if NOT accepted.) & $\begin{array}{l}16 . \\
\text { Status }\end{array}$ \\
\hline 2 & $\begin{array}{l}\text { Drawing \# H-1-82162 } \\
\text { 1.Change drawing number H-1-82228 to P\&ID H-1-82224 at cord. F-8 } \\
\text { of this drawing. } \\
\text { 2Change piping ID number VPSCHW-101-SS- } 1 \text { " to VPSCHW-201-SS- } \\
1 \text { " at cord. F-7. } \\
\text { 3.Change drawing number H-1-82228 to P\&ID H-1-82224, cord B-8 at } \\
\text { cord. F- } 1 \text { of this drawing. } \\
\text { 4.Change piping ID number VPSCHW-102-SS-1" to VPSCHW-202-SS- } \\
1 \text { " at cord. F-2. } \\
5 . \text { Change drawing number H-1-82161, cord C-1 to cord. D-1 at cord. } \\
\text { D-8 of this drawing. } \\
\text { 6. Change piping ID number LW-102-SS-1" to LW-202-SS-1" at cord. } \\
\text { C-2. } \\
\text { 7.Change drawing number H-1-82162, cord E-1 to H-1-82163, cord. E- } \\
1 \text { at cord. D-1 of this drawing. }\end{array}$ & & $\begin{array}{l}\text { 1. Will be made to match. } \\
\text { 2. Wild Card }(*) \text {. } \\
\text { 3. Will be made to match. } \\
\text { 4. Wild Card }(*) \text {. } \\
\text { 5. Done. } \\
\text { 6. Wild Card }(*) \text {. } \\
\text { 7. Done. }\end{array}$ & $\mathrm{OK}$ \\
\hline
\end{tabular}

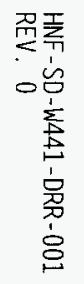




\begin{tabular}{|c|l|l|}
\hline \multirow{2}{*}{ REVIEW COMMENT RECORD (RCR) } & \multicolumn{1}{|l|}{ 1. Date } & 2. Review No. \\
\cline { 2 - 3 } & $\begin{array}{c}\text { 3. Project No. } \\
\text { W-441 }\end{array}$ & $\begin{array}{l}\text { 4. Page } \\
3 \text { of } 4\end{array}$ \\
\hline
\end{tabular}

\begin{tabular}{|c|c|c|c|c|}
\hline $\begin{array}{l}12 . \\
\text { Item }\end{array}$ & $\begin{array}{l}\text { 13. Comment(s)/Discrepancy(s) (Provide technical justification for the comment and } \\
\text { detailed recommendation of the action required to correct/ resolve the } \\
\text { discrepancy/problem indicated.) }\end{array}$ & $\begin{array}{l}14 . \\
\text { Hold } \\
\text { Point }\end{array}$ & 15. Disposition (Provide justification if NOT accepted.) & $\begin{array}{l}16 . \\
\text { Status }\end{array}$ \\
\hline 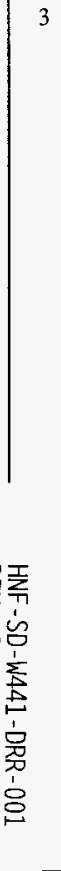 & 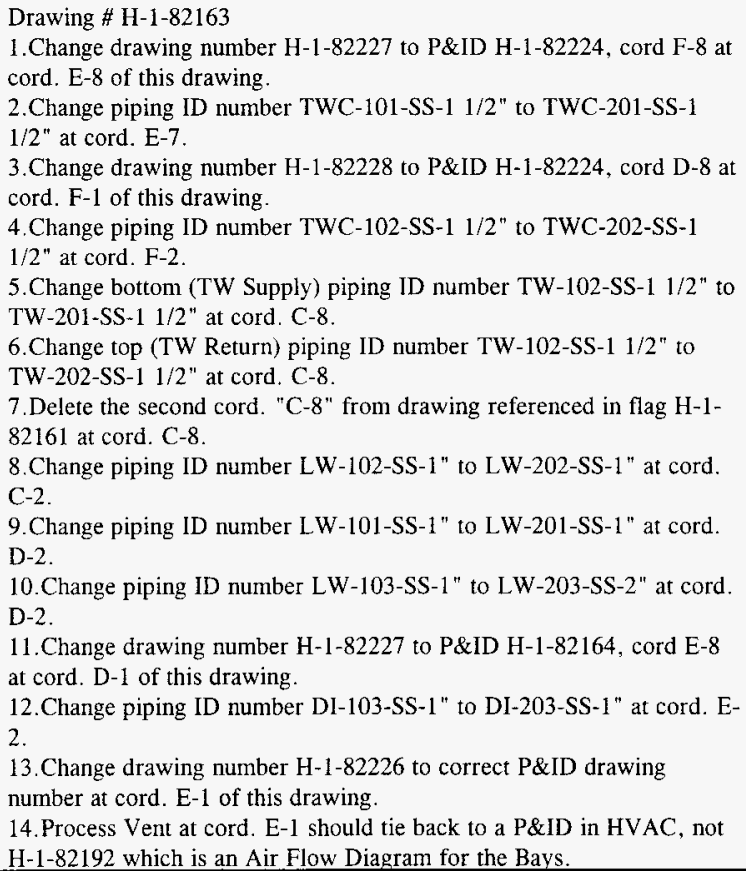 & & $\begin{array}{l}\text { 1. Will make correct. } \\
\text { 2. Wild Card }(*) \\
\text { 3. Will make correct. } \\
\text { 4. Wild Card }\left(^{*}\right) \text {. } \\
\text { 5. Wild Card }\left(^{*}\right) \text {. } \\
\text { 6. Wild Card }\left(^{*}\right) \text {. } \\
\text { 7. Done. } \\
\text { 8. Wild Card }(*) \text {. } \\
\text { 9. Wild Card }\left({ }^{*}\right) \text {. } \\
\text { 10. Wild Card }\left(^{*}\right) \text {. } \\
\text { 11.It actually flows through facility before } 82164 \text {. Will } \\
\text { correct. } \\
\text { 12. Wild Card }\left(^{*}\right) \text {. } \\
\text { 13. Will correct. } \\
\text { 14. Will correct. }\end{array}$ & OK \\
\hline
\end{tabular}




\begin{tabular}{|c|c|c|}
\hline DEVIEY COMOMTNT DECODD & $\begin{array}{l}\text { 1. Date } \\
\quad 10-10-96 \\
\end{array}$ & 2. Review No. \\
\hline 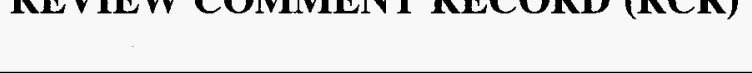 & $\begin{array}{l}\text { 3. Project No. } \\
\text { W-441 }\end{array}$ & $\begin{array}{l}\text { 4. Page } \\
4 \text { of } 4\end{array}$ \\
\hline
\end{tabular}

\begin{tabular}{|c|c|c|c|c|}
\hline $\begin{array}{l}12 . \\
\text { Item }\end{array}$ & $\begin{array}{l}\text { 13. Comment(s)/Discrepancy(s) (Provide technical justification for the comment and } \\
\text { detailed recommendation of the action required to correct/ resolve the } \\
\text { discrepancy/problem indicated.) }\end{array}$ & $\begin{array}{l}14 . \\
\text { Hold } \\
\text { Point }\end{array}$ & 15. Disposition (Provide justification if NOT accepted.) & $\begin{array}{l}16 . \\
\text { Status }\end{array}$ \\
\hline 4 & $\begin{array}{l}\text { Drawing \# H-1-82164 } \\
\text { 1.Change piping ID number LW-001-SS-2" to LW-203-SS-2" at cord. } \\
\text { E-7. } \\
\text { 2.Change drawing number H-1-82161, cord. E-1 to P\&ID H-1-82163, } \\
\text { cord. D-1 at cord. E-8 of this drawing. } \\
\text { 3.Change piping ID number LW-108-SS-3/4" to LW-208-SS-3/4" at } \\
\text { cord. C-2. } \\
\text { 4.Change drawing number H-1-822XX to P\&ID H-1-82223, cord. C-8 } \\
\text { at cord. C-1 of this drawing. } \\
\text { 5.Change drawing title Instr. Nitrogen to N2 and drawing H-1-82226 to } \\
\text { the correct P\&ID at cord D-1. } \\
\text { 6.Change valve numbers LW-V-006 and LW-QD-007 to N2-V-006 and } \\
\text { N2-QD-007 at cord. D-3 and C-3. }\end{array}$ & & $\begin{array}{l}\text { 1. Should be corrected to PWC-xxx-x. Need to change on } \\
82223 \text { also. } \\
\text { 2. JJI: added to CM Action List } \\
\text { 3. Corrected for PWC redesign. } \\
\text { 4. Corrected. } \\
\text { 5. Corrected; changed to IA. } \\
\text { 6. Corrected; changed to IA. }\end{array}$ & OK \\
\hline
\end{tabular}

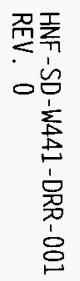




\begin{tabular}{|l|l|l|}
\hline \multirow{2}{*}{ REVIEW COMMENT RECORD (RCR) } & $\begin{array}{l}\text { 1. Date } \\
\text { 2. Review No. }\end{array}$ \\
\cline { 2 - 3 } & $\begin{array}{l}\text { 3. Project No. } \\
\text { W-441 }\end{array}$ & $\begin{array}{l}\text { 4. Page } \\
1 \text { of } 1\end{array}$ \\
\hline
\end{tabular}

\begin{tabular}{|c|c|c|c|c|}
\hline 5. Document Number(s)/Title(s) & $\begin{array}{l}\text { 6. Program/Project/ } \\
\text { Building Number }\end{array}$ & 7. Reviewer & 8. Organization/Group & 9. Location/Phone \\
\hline $\begin{array}{l}\text { Cold Vacuum Drying Facility } 90 \% \text { Design } \\
\text { Review, H-1-82164, sht } 1 \text { of } 1\end{array}$ & CVD/W-441 & John L. Austin & $\begin{array}{l}\text { SNF PROJECTS/ } \\
\text { STARTUP }\end{array}$ & ТСРC/373-6439 \\
\hline
\end{tabular}

17. Comment Submittal Approval:

Organization Manager (Optional)
10. Agreement with indicated comment disposition(s)

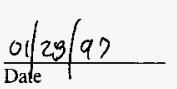

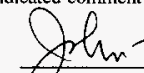

Reviewer/Point :

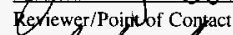

13. Comment(s)/Discrepancy(s) (Provide technical justification for the comment and

Item detailed recommendation of the action required to correct/ resolve the discrepancy/problem indicated.)

1. Remove H-1-"82XXX" at the process vent and add complete drawing number \& cord. at cord. F-1.

2. Remove LW-TK-"XXXX" at the Process Vent and add complete equipment number at cord. F-2.

3. Remove "SLOPE TO ?" at the Process Vent at cord. F-4. If this is required, add this information to the piping drawings.

4. Remove $\mathrm{H}-1-" 822 \mathrm{XX}$ " to the storage tank and add complete drawing number \& cord. at cord. C-1.

5. Remove "CW3" from both piping numbers -041-SS-1 " \& -042-SS-1" and add the correct system. This looks to be chilled by system

"VPSCHW"? The drawing H-1-82227 referenced looks to be wrong and P\&ID H-1-82224 should be referenced, all located at cord. D-8. The flow from one P\&ID to another is not clear.

6. Remove "H-1-82227" Mech. Utilities at both places and add the Chill Water P\&ID "H-1-82224" if this is the means for cooling.

11. CLOSED
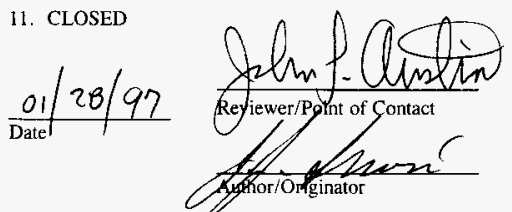
Date

2. $202 \div 27$ ـــ

\begin{tabular}{|c|c|}
\hline $\begin{array}{l}14 . \\
\text { Hold }\end{array}$ & 15. Disposition (Provide justification if NOT accepted.) \\
\hline
\end{tabular}

JJI: This drawing is for the PWC skid, a $90 \%$ design has be been submitted having the requested corrections.

See disposition item \#1.

See disposition item \#1.

See disposition item \#1.

Chilled water system deleted from the PWC system. 


\begin{tabular}{|l|l|l|}
\hline \multirow{2}{*}{ REVIEW COMMENT RECORD (RCR) } & 1. Date $10 / 3 / 96$ & 2. Review No. \\
\cline { 2 - 4 } & $\begin{array}{l}\text { 3. Project No. } \\
\text { W-441-C1 }\end{array}$ & $\begin{array}{l}\text { 4. Page } \\
1 \text { of } 6\end{array}$ \\
\hline
\end{tabular}

\begin{tabular}{|l|l|l|l|l|}
\hline 5. Document Number(s)/Title(s) & $\begin{array}{l}\text { 6. Program/Project/ } \\
\text { Building Number } \\
\text { SNF/CVDF/142K }\end{array}$ & 7. Reviewer & A. A. Zaman \\
$\begin{array}{l}\text { Cold Vacuum Drying Facility 90\% Design } \\
\text { Review }\end{array}$ & SNFP Safety & $\begin{array}{l}\text { 840NORTHGT/Group } \\
376-1692\end{array}$ \\
\hline
\end{tabular}

17. Comment Submittal Approval:

Organization Manager (Optional)
10. Agreement with indicated comment disposition(s)

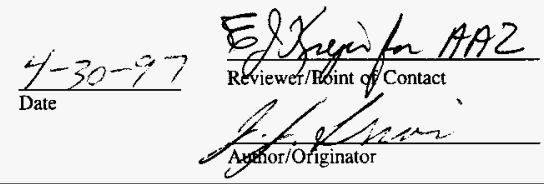

11. CLOSED

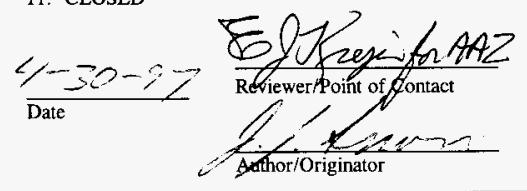

\begin{tabular}{|c|c|c|c|c|}
\hline $\begin{array}{l}12 . \\
\text { Item }\end{array}$ & $\begin{array}{l}\text { 13. Comment(s)/Discrepancy(s) (Provide technical justification for the comment and } \\
\text { detailed recommendation of the action required to correct/ resolve the discrepancy/problem } \\
\text { indicated.) }\end{array}$ & $\begin{array}{l}14 . \\
\text { Hold } \\
\text { Point }\end{array}$ & 15. Disposition (Provide justification if NOT accepted.) & $\begin{array}{l}16 . \\
\text { Status }\end{array}$ \\
\hline 1. & $\begin{array}{l}\text { General: a)Either the applicable DOE Orders(e.g General Design Criteria DOE } \\
6430.1 \text { A) standards(1020-94, etc.), Site procedures(WHC-CM-4-46 for safety } \\
\text { classification and requirements),etc. needs to be referenced in the applicable spec } \\
\text { or pertinent requirements need to be established in Merrick Specs. } \\
\text { b) Environmental conditions (temperature, humidity, radiation, chemical, etc) } \\
\text { need to be specified. } \\
\text { c) Any installation tolerances chart, linear, angular, etc., for piping, equipment } \\
\text { and piping support? }\end{array}$ & & $\begin{array}{l}\text { a,b) Disagree. Requirements are in the performance specification and } \\
\text { have been integrated into the design by the } \mathrm{A} / \mathrm{E} \text {. Reiteration of the } \\
\text { requirements in the construction specification is not necessary. } \\
\text { c) Industry "standards" are adequate. }\end{array}$ & \\
\hline 2. & $\begin{array}{l}\text { General: "Scope" or the "Work" sections do not contain out-line for the basic } \\
\text { engineering or system requirements that are establish acceptance guidelines for the } \\
\text { Structure Systems and Components(SSC) for the Cold Vacuuming Facilities. }\end{array}$ & & AE's responsibility to interpret by design requirements. & \\
\hline 3. & $\begin{array}{l}\text { General: Fluor has written specifications for CSB. Cold Vacuuming could benefit } \\
\text { from use of those minimum as guidelines. Some may be directly applicable. }\end{array}$ & & Agreed. & \\
\hline 4. & General: The System Design Description should be part of the review package. & & SDD will be part of the Final Design Report. & \\
\hline 5 . & $\begin{array}{l}\text { General: Use of copper and fibre glass, PVC needs to be evaluated for Natural } \\
\text { Hazards Phenomena(NPH) application, if any. }\end{array}$ & & Outside of Scope of Work. & \\
\hline
\end{tabular}




\begin{tabular}{|l|l|l|}
\hline \multirow{2}{*}{ REVIEW COMMENT RECORD (RCR) } & $\begin{array}{l}\text { 1. Date Review No. } \\
10 / 3 / 96\end{array}$ \\
\cline { 2 - 4 } & $\begin{array}{c}\text { 3. Project No. } \\
\text { W-441-C1 }\end{array}$ & $\begin{array}{c}\text { 4. Page } \\
2\end{array}$ \\
\hline
\end{tabular}

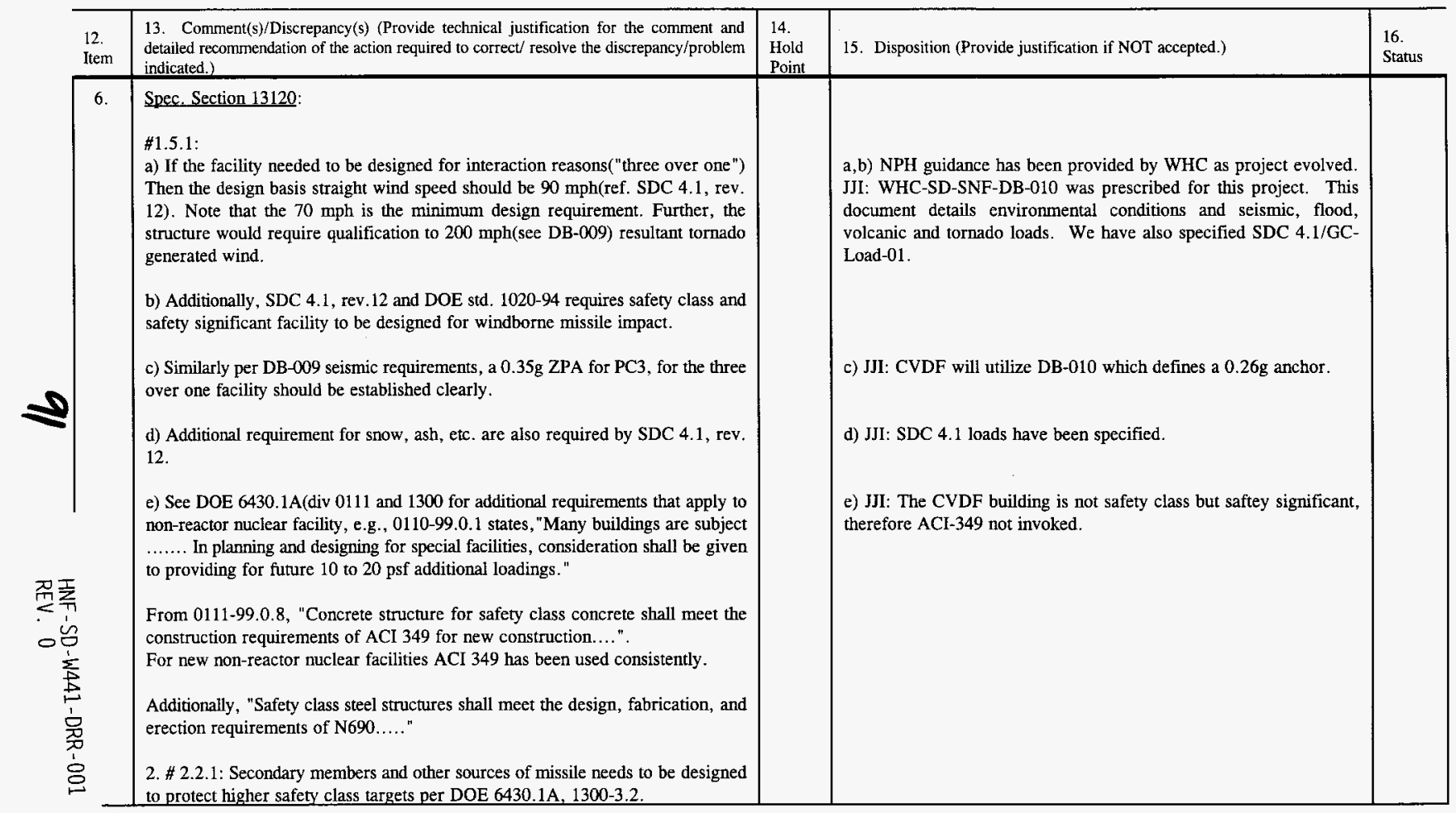




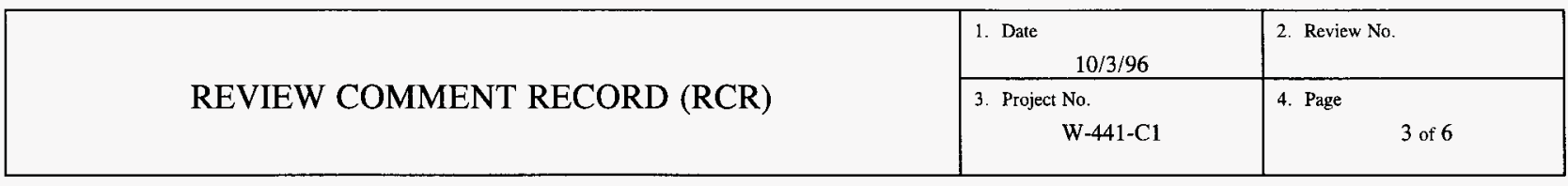

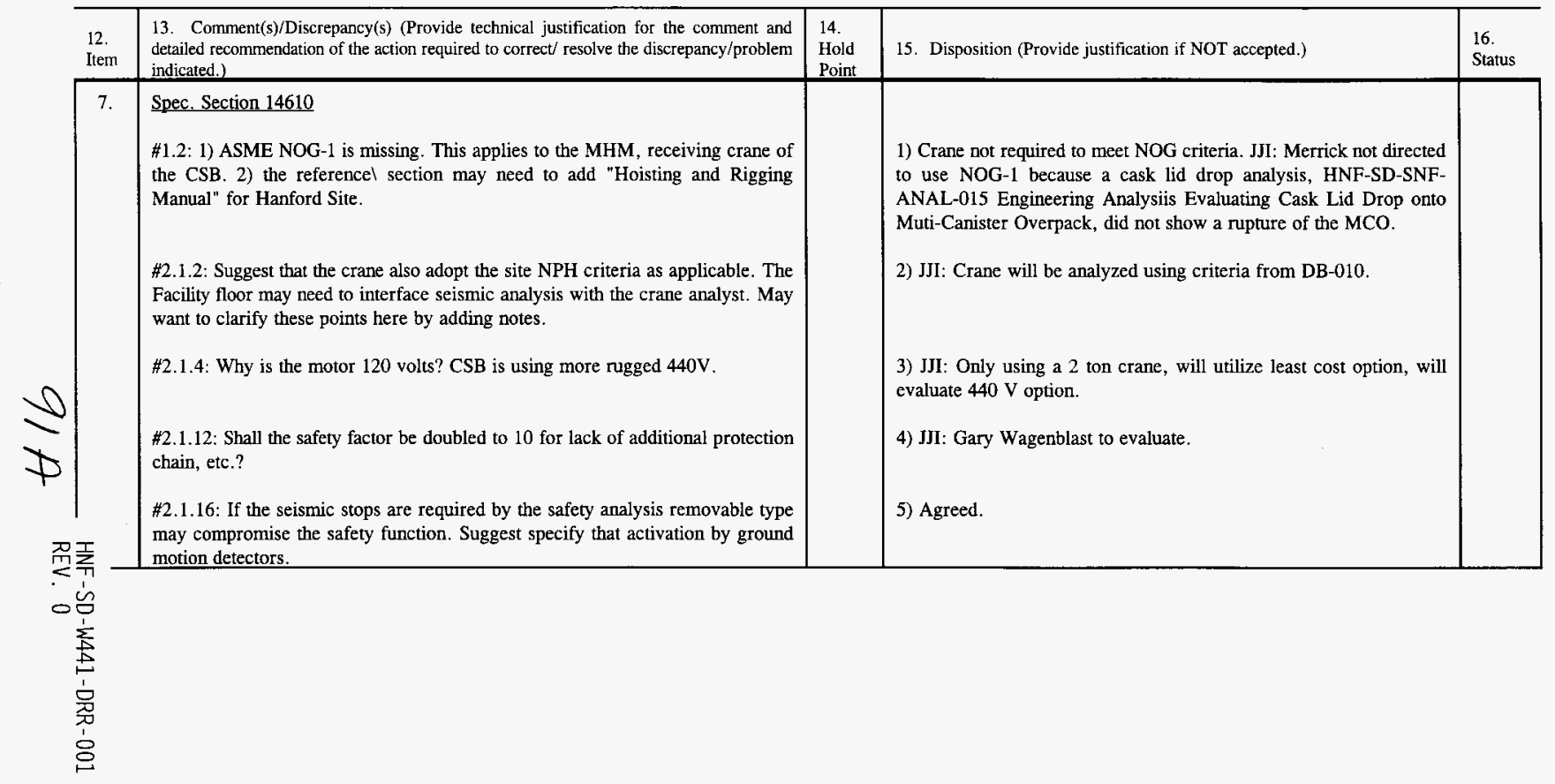




\begin{tabular}{|l|l|l|}
\hline \multirow{2}{*}{ REVIEW COMMENT RECORD (RCR) } & \begin{tabular}{l} 
2. Date Review No. \\
\cline { 2 - 3 }
\end{tabular} & $\begin{array}{c}\text { 3. Project No. } \\
\text { W-441-C1 }\end{array}$ \\
\hline
\end{tabular}

12. 13. Comment(s)/Discrepancy(s) (Provide technical justification for the comment and Ietailed recommendation of the action required to correct/ resolve the discrepancy/problem indicated.)

8. Spec. Section 15140:

Some of the piping if safety class $2 /$ safety significant may require seismic analysis. The criteria for such analysis as given in SDC 4.1 is missing. Rod Hangers may not be the best option for such piping.

\#1.2: From the System Design Description Document and P\&ID it is obvious that we have process piping. Codes like ASME III, B31.1(Power Piping) and B31.3(Chemical and Petroleum Refinery Piping) applies per recommended codes in DOE 6430.1A.

\#2.1: a)The details for the outlined supports needs to $x$-referenced by calling out the drawing numbers. These drawings should be added to the reference. Otherwise, potential non conformance for installed supports.

b) Some of the process lines are stainless steel. Identify what kind of support materials are for pipe attachments and other support items.

\#2.5: May want to clarify clearances between the piping and the penetration sleeve. Note: Some of the penetrations in the radio-active zones will require 뀰 design to prevent shine through these. May need to specify that here. Also, the sealant will require withstanding to radiation field( + temperature ).

12. \#3.2.5: The use of the riser clamp may require it to bear on welded lugs on the piping. This or other mechanism needs to be clarified here.

13. \#3.6: May want to call out qualified hilti kwik or super kwiks (wedge type) for base plates. And design embedded plates with nelson studs, etc. Sleeve type anchors(Phillips Red-Heads) had load capacity problems in the past.

14. \#3.7: Provide reference basis for the table ( any calc. or standard)

\begin{tabular}{|l|l|l|}
\hline $\begin{array}{l}\text { Hold } \\
\text { Point }\end{array}$ & 15. Disposition (Provide justification if NOT accepted.) & $\begin{array}{l}16 . \\
\text { Status }\end{array}$ \\
& $\begin{array}{l}\text { 1) Agree, JJI: DB-010 will be applied to all seismic analyses. } \\
\text { which the design is adhered to. }\end{array}$ & \\
a) JJI: Will be part of Title III design effort. & B31.3 to \\
b) JJI: Will be part of Title III design effort. & \\
c) JJI: Will be part of Title III design effort. & \\
f) TBD &
\end{tabular}




\begin{tabular}{|l|l|l|}
\hline \multirow{2}{*}{ REVIEW COMMENT RECORD (RCR) } & $\begin{array}{l}\text { 2. Date Review No. } \\
10 / 3 / 96\end{array}$ \\
\cline { 2 - 4 } & $\begin{array}{c}\text { 3. Project No. } \\
\text { W-441-C1 }\end{array}$ \\
\hline
\end{tabular}

\begin{tabular}{|c|c|c|c|c|c|}
\hline & $\begin{array}{l}12 . \\
\text { Item }\end{array}$ & $\begin{array}{l}\text { 13. Comment(s)/Discrepancy(s) (Provide technical justification for the comment and } \\
\text { detailed recommendation of the action required to correct/resolve the discrepancy/problem } \\
\text { indicated.) }\end{array}$ & $\begin{array}{l}14 . \\
\text { Hold } \\
\text { Point }\end{array}$ & 15. Disposition (Provide justification if NOT accepted.) & $\begin{array}{l}16 . \\
\text { Status }\end{array}$ \\
\hline & 9. & $\begin{array}{l}\text { Spec. Section 15406: } \\
\text { \#1.2: Include the Power Piping ASME B31.1 in the reference. } \\
\text { \#2.2: DOE } 6430.1 \mathrm{~A}, 1300-74 \text {, "Leakage monitoring shall be provided to detect } \\
\text { leakage into the space between the primary pipe and the secondary confinement } \\
\text { barrier." Designer needs to address this. } \\
\text { Is the double confinement design backed up by safety analysis(requirement for } \\
\text { multiple confinement barriers(DOE } 6430.1 \mathrm{~A}, 1300-7.2) \text { ? } \\
\text { \#2.2: Provide the following: } \\
\text { Justification for using PVC outside pipe. } \\
\text { Provide criteria for analysis for the metallic inside and non-metallic outside piping } \\
\text { commensurate with their safety function. } \\
\text { Note: that PVC is susceptible to structural degradation by radiation aging. }\end{array}$ & & $\begin{array}{l}\text { Power piping is not appropriate for this application. ASME B31.3 is } \\
\text { the correct specification. } \\
\text { See Detail A on H-1-82229 and P\&ID on H-1-82223. } \\
\text { The safety analysis for double confinement will be in the SAR. } \\
\text { Steel for low-expansion coefficeient PVC for corrosion resistance and } \\
\text { cost. } \\
\text { The safety analysis for double confinement will be in the SAR. } \\
\text { PVC is buried and not exposed. JJI: Max. Expected dose is 1xE }+4 \\
\text { rads, therefore no radiation damage expected for PVC. }\end{array}$ & \\
\hline 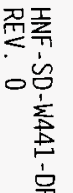 & 10. & $\begin{array}{l}\text { Spec. Section 15456: } \\
\text { 18. \#1.3.1.1 \&1.3.1.4: Loading conditions, codes and allowable needs to be } \\
\text { specified. For example, if the tanks require Natural Hazards Phenomena } \\
\text { qualification(DOE } 5480.28 \text {, DOE Std. } 1020-94 \text { and SDC } 4.1 \text { ) that needs to be } \\
\text { specified here. Need to mention what Safety Class(SC). Ground motion spectrum } \\
\text { is safety classification dependent. }\end{array}$ & & $\begin{array}{l}\text { The safety equipment list has determined that these tanks are safety } \\
\text { significant. The construction specification will be changed to require } \\
\text { that the tanks shall be designed, fabricated, and installed to } \\
\text { appropriate codes, ASME Secton 8, and design criteria, WHC-SD- } \\
\text { SNF-DB-0100. }\end{array}$ & \\
\hline
\end{tabular}




\begin{tabular}{|c|l|l|}
\hline \multirow{2}{*}{ REVIEW COMMENT RECORD (RCR) } & $\begin{array}{l}\text { 1. Date } \\
10 / 3 / 96\end{array}$ \\
\cline { 2 - 3 } & $\begin{array}{c}\text { 3. Project No. Review No. } \\
\text { W-441-C1 }\end{array}$ & 4. Page \\
\hline
\end{tabular}

\begin{tabular}{|c|c|c|c|c|}
\hline $\begin{array}{l}12 . \\
\text { Item }\end{array}$ & $\begin{array}{l}\text { 13. Comment(s)/Discrepancy(s) (Provide technical justification for the comment and } \\
\text { detailed recommendation of the action required to correct/resolve the discrepancy/probiem } \\
\text { indicated.) }\end{array}$ & $\begin{array}{l}14 . \\
\text { Hold } \\
\text { Point }\end{array}$ & 15. Disposition (Provide justification if NOT accepted.) & $\begin{array}{l}16 . \\
\text { Status }\end{array}$ \\
\hline 11. & $\begin{array}{l}\text { Spec. Section 15480: } \\
\text { 19. It is not clear that valves are to be supplied with appurtenances(e.g. limit } \\
\text { witch, motor, handwheel, etc.). Any Certificate of Compliance }{ }^{\circ} \text { of C) required? }\end{array}$ & & $\begin{array}{l}\text { This section does not apply to skid-built equipment. Controlled valves } \\
\text { for the facility are specified in Section } 17100 \text {, and will be included } \\
\text { more explicitly in instrument list/specs. Valves with automatic } \\
\text { actuators are under instrument list. Valves that are manual are under } \\
\text { valve list. }\end{array}$ & \\
\hline 12. & $\begin{array}{l}\text { Spec. Section 15856: } \\
\text { 20. a) Specify required particulate removal efficiency. DOP test may have been } \\
\text { replaced in Hanford by a more friendly chemical. } \\
\text { b) The seismic quatification requirements need to be specified(at location required } \\
\text { response spectrum). } \\
\text { c) Do we need to specify the fire resistance characteristics of the medium? }\end{array}$ & & $\begin{array}{l}\text { a) Particle removal efficiency is specified in } 2.4 .2 \text {. JJ: Brian Fillion } \\
\text { had same comment, will utilize Hanford mehthods to test filters. } \\
\text { b) Merrick is designig the anchorage system for all equipment and } \\
\text { piping. A DCN will be issued to the Construction Spec. when the } \\
\text { design is completed. } \\
\text { c) The filter medium characteristics are described in MIL-F-51068. }\end{array}$ & \\
\hline 3. & $\begin{array}{l}\text { Spec. Section } 16450 \text { : } \\
\text { Do we need to specify separate groundlings for instruments, equipment, building, } \\
\text { etc.? }\end{array}$ & & $\begin{array}{l}\text { Specification Section } 16450 \text {, Paragraph } 3.1 .2 \text { is intended to address al1 } \\
\text { equipment grounding requirements generically. Specific grounding for } \\
\text { instruments, equipment, building, etc. are detailed on drawings } \\
\text { associated with the various equipment. No change required. }\end{array}$ & \\
\hline
\end{tabular}




\section{REVIEW COMMENT RECORD (RCR)}

\begin{tabular}{|c|l|}
\hline $\begin{array}{l}\text { 1. Date } \\
\text { Oct. 11, 1996 }\end{array}$ & 2. Review No. \\
\hline $\begin{array}{c}\text { 3. Project No. } \\
\text { W-441-C1 }\end{array}$ & 4. Page \\
\hline
\end{tabular}

\section{Document Number(s)/Title(s)}

\section{CVDF $90 \%$ Design Review}

17. Comment Submittal Approval

Organization Manager (Optional)

\begin{tabular}{l|l}
$\begin{array}{l}\text { 6. Program/Project/ } \\
\text { Building Number } \\
\text { SNFP/CVDF } / 142 K\end{array}$ & 7. Reviewer \\
\hline
\end{tabular}

10. Agreement with indicated comment disposition(s)

$$
\frac{11 / 15 / 96}{\text { Date }}
$$

Reviewer/Point of,Contad.
8. Organization/Group

Fire Protection

11. CLOSED

$11 / 15 / 96$

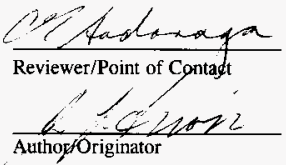

Date

9. Location/Phone

840 Northgate/2-1378

\section{$\ell$}

$+2 \cos 2$

\begin{tabular}{|c|c|c|c|c|}
\hline $\begin{array}{l}12 . \\
\text { Item }\end{array}$ & $\begin{array}{l}\text { 13. Comment(s)/Discrepancy(s) (Provide technical justification for the comment and } \\
\text { detailed recommendation of the action required to correct/ resolve the discrepancy/problem } \\
\text { indicated.) }\end{array}$ & $\begin{array}{l}14 . \\
\text { Hold } \\
\text { Point }\end{array}$ & 15. Disposition (Provide justification if NOT accepted.) & $\begin{array}{l}16 . \\
\text { Status }\end{array}$ \\
\hline 1 & $\begin{array}{l}\text { The Process Bay roof was changed to a membrane roof with rigid insulation. A } \\
\text { concern was raised with the CSB membrane roof with rigid polyiobcyanurate } \\
\text { insulation. } 10 \mathrm{CFR} 72.122 \text { (c) which is required for NRC equivalency states that } \\
\text { noncombustible and heat-resistant materials must by used wherever practical } \\
\text { throughout the ISFSI or MRS, particularly in locations vital to the control of } \\
\text { radioactive materials and to the maintenance of safety control functions. The } \\
\text { CSB roof design was changed to a standing seam roof with batt insulation for } \\
\text { wind loading purposes, but also met the NRC fire protection criteria. I've } \\
\text { attached the cc:mail memo on this issue. }\end{array}$ & & 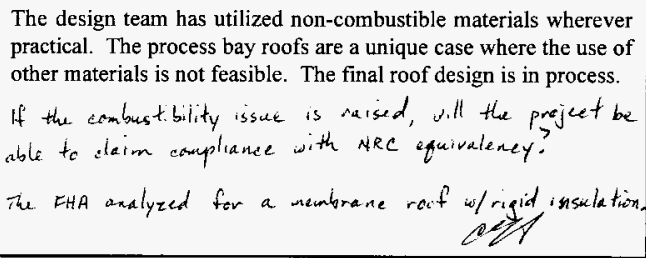 & \\
\hline 2 & $\begin{array}{l}\text { The south outside stairwell to the mechanical room is not required to be protected } \\
\text { per NFPA 101, 5-2.2.6.3, Exception No. } 2 \text {. However, the question of protection } \\
\text { for vertical openings (because this enclosed stairwell connects the ground floor } \\
\text { and second floor) was raised. NFPA was consulted and suggested two options: } \\
\text { 1) have the stairwell meet the requirements of NFPA } 101,6-3 \text {, or } 2 \text { ) not fully } \\
\text { enclose the stairwell so that smoke that entered the stairwell would be vented } \\
\text { outside rather than to the other floor. The summary of the conversation with } \\
\text { NFPA is also attached. }\end{array}$ & & 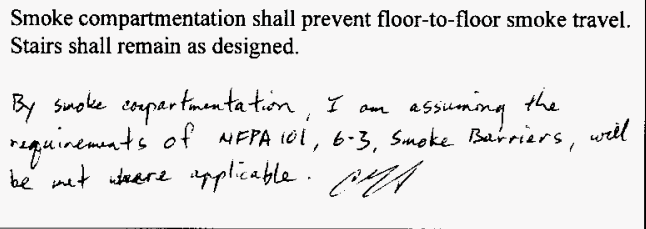 & \\
\hline
\end{tabular}




\begin{tabular}{|l|l|l|}
\hline \multirow{2}{*}{ REVIEW COMMENT RECORD (RCR) } & $\begin{array}{l}\text { 1. Date } \\
\text { Oct. 11, 1996 }\end{array}$ & \multicolumn{2}{|l|}{ Review No. } \\
\cline { 2 - 4 } & $\begin{array}{l}\text { 3. Project No. } \\
\text { W-441-Cl }\end{array}$ & $\begin{array}{l}\text { 4. Page } \\
2 \text { of } 2\end{array}$ \\
\hline
\end{tabular}

\section{DON'T SAY IT --- Write It! DATE: October 11, $1996 \quad 7: 30 \mathrm{am}$}

TO: $\quad$ File

FROM:Bud Bucci

Telephone: $376-1735$

\section{cc: PHMC-FPE's}

\section{SUBJECT: LIFE SAFETY CODE QUESTION}

I called Ron Cote' at NFPA to discuss the application of Section 5-2.2.6.3, Exception \#2, which allows outside stairs serving not more than two adjacent stories to be unprotected provided there is a second remotely located exit. This question came up on the Cold Vacuum Drying Facility. I told Ron we had a situation where we believe we qualify for this exception, but was wondering if the vertical penetration protection requirements of Chapter 6 still apply.

At first Ron was thinking that due to the arrangement of the stairs (i.e. being outside - although with an enclosure) they were no different than having a window to the exterior. He then said the more we discussed it, he could see that because the stairs are enclosed, the smoke could actually be channelled from one floor to the next, whereas with windows, the smoke would tend to be dispersed to the outside. Ron said he doesn't believe Chapter 5 and Chapter 6 are aware of this and perhaps there needs to be a reference. I asked Ron if I should follow-up in any way and he said he didn't think a formal interpretation would help in this particular case. I expressed to Ron that I thought we may need at least a basic degree of smoke separation between floors as required by Chapter 6 . Ron agreed and also suggested as an alternative that the outside 盄参 stairs not be fully enclosed. This way they would act more like windows and not channel the smoke. 


\begin{tabular}{|l|l|l|l|l|}
\hline \multirow{2}{*}{ REVIEW COMMENT RECORD (RCR) } & i. Date & Review No. \\
\cline { 2 - 4 } & 3. Project No. & 4. Page \\
\hline
\end{tabular}

\begin{tabular}{|c|c|c|c|c|}
\hline 5. Document Number(s)/Title(s) & $\begin{array}{l}\text { 6. Program/Project/ } \\
\text { Building Number }\end{array}$ & 7. Reviewer & 8. Organization/Group & 9. Location/Phone \\
\hline $\begin{array}{l}\text { Cold Vacuum Drying Facility } 90 \% \text { Design } \\
\text { Review }\end{array}$ & $\mathrm{SNF} / \mathrm{CVDF} / 142 \mathrm{~K}$ & Glyn D. Trenchard & DOE-RL/SNFP & $\begin{array}{l}\text { MO-0277/B114A/ } \\
373-4016\end{array}$ \\
\hline
\end{tabular}

17. Comment Submittal Approval:

Organization Manager (Optional)
10. Agreement with indicated comment disposition(s)

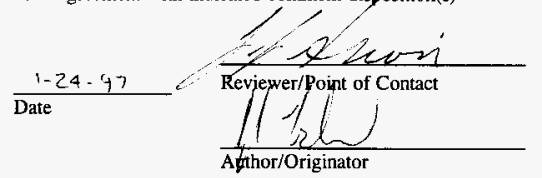

11. ClOSED

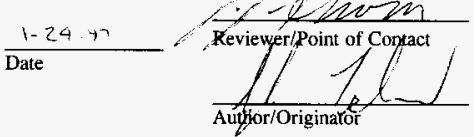

\begin{tabular}{|c|c|c|c|c|}
\hline $\begin{array}{l}12 . \\
\text { Item }\end{array}$ & $\begin{array}{l}\text { 13. Comment(s)/Discrepancy(s) (Provide technical justification for the comment and } \\
\text { detailed recommendation of the action required to correct/resolve the discrepancy/problem } \\
\text { indicated.) }\end{array}$ & $\begin{array}{l}14 . \\
\text { Hold } \\
\text { Point }\end{array}$ & 15. Disposition (Provide justification if NOT accepted.) & $\begin{array}{l}16 . \\
\text { Status }\end{array}$ \\
\hline 1. & $\begin{array}{l}\text { General: Cost information was not provided. D\&D cost, specifically was } \\
\text { expected. }\end{array}$ & & $\begin{array}{l}\text { JJI: Has been provided in a separate submittal but is regarded to be } \\
\text { top secret. }\end{array}$ & \\
\hline 2. & $\begin{array}{l}\text { General: Has it been determined that the seismic restraint system is not needed? } \\
\text { Will the engineering cost of deleting it should be compared to the construction } \\
\text { savings of not constructing it. }\end{array}$ & & $\begin{array}{l}\text { Decision made to provide foundations if necessary to provide in } \\
\text { future. }\end{array}$ & \\
\hline 3. & $\begin{array}{l}\text { General: Is the full size mezzanine needed? Will the MCO top be accessed from } \\
\text { the mezzanine? - If not, why is it there? }\end{array}$ & & $\begin{array}{l}\text { JJI: Worker access to the Cask top from the Mezzanine has been } \\
\text { requested by DESH Operations. }\end{array}$ & \\
\hline 4. & $\begin{array}{l}\text { General: Is there any effort to have unique identifiers in the CVD bays to easily } \\
\text { distinguish which bay you are in? }\end{array}$ & & Signage shall be provided to identify room/bay information. & \\
\hline 5. & $\begin{array}{l}\text { General: There is no reference to the Eagle Management Plan or any potential } \\
\text { limitations due to the presence of the Eagles. }\end{array}$ & & $\mathrm{JJI}$ : Construction Manger is following the management plan & \\
\hline 6. & $\begin{array}{l}\text { General: What is the cost of the windows and corresponding blinds (and their } \\
\text { installation) in the administrative area? Is this cost justifiable in a temporary } \\
\text { facility? }\end{array}$ & & $\begin{array}{l}\text { The proposed blinds represent a low-cost solution to window } \\
\text { treatment. JJI: Windows may be deleted, added to CM Action List. }\end{array}$ & \\
\hline 7. & $\begin{array}{l}\text { Page } 17190-2 \text {, Section } 3.1 .4 \text { refers to the project as "W-411". This should be W- } \\
441 \text {. }\end{array}$ & & Agreed. & \\
\hline
\end{tabular}




\section{REVIEW COMMENT RECORD (RCR)}

$10 / 3 / 96$

3. Project No.

W-441-C1

1 of 1

\begin{tabular}{|c|c|c|c|c|}
\hline 5. Document Number(s)/Title(s) & $\begin{array}{l}\text { 6. Program/Project/ } \\
\text { Building Number }\end{array}$ & 7. Reviewer & 8. Organization/Group & 9. Location/Phone \\
\hline $\begin{array}{l}\text { Cold Vacuum Drying Facility } 90 \% \text { Design } \\
\text { Review }\end{array}$ & SNF/CVDF/142K & Cary D Jackson & SNF Safety & MO401/33/373-3808 \\
\hline
\end{tabular}

17. Comment Submittal Approval:

10. Agreement with indicated comment disposition(s)

Organization Manager (Optional)

10. Agreement with indicated comment disposition(s)

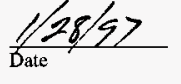

Reviewer/Poin of Contact

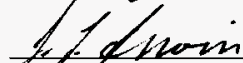

Aruthorioriginator

12 13. Comment(s)/Discrepancy(s) (Provide technical justification for the comment and detailed recommendation of the action required to correct/ resolve the discrepancy/problem indicated.)

Hold

Section 01110 Industrial Safety and Health:

Take out CESH and add DOE Order 5480.9A Contractor Project

Safety and Health Management; DOE Order 5480.10 Contractor I. H.

Program; DOE Order 5480.7A Fire Protection

2. Also in 1.3.1 (same section) do not limit yourself to

what is listed in A- O. Make statement that JSA/JHA includes but is not

limited to the following (something like that).

\begin{tabular}{|l|l|l|l|l|}
\hline & & & & \\
\hline \\
\hline
\end{tabular}




\begin{tabular}{|c|c|c|}
\hline \multirow{2}{*}{ REVIEW COMMENT RECORD (RCR) } & $\begin{array}{c}\text { 1. Date } \\
09 / 26 / 96\end{array}$ \\
\cline { 2 - 4 } & $\begin{array}{r}\text { 3. Project No. Revicw No. } \\
\text { W-441-C1 }\end{array}$ \\
\hline
\end{tabular}

\begin{tabular}{|l|l|l|l|}
\hline 5. Document Number(s)/Title(s) & $\begin{array}{l}\text { 6. Program/Projec/ } \\
\text { Building Number } \\
\text { SNF/CVDF/142K }\end{array}$ & 7. Reviewer & 8. Organization/Group \\
$\begin{array}{l}\text { Cold Vacuum Drying Facility 90\% Design } \\
\text { Review }\end{array}$ & Jurtz Basins Radiological \\
\hline
\end{tabular}

17. Comrnent Submittal Approval:

Organization Manager (Optional)
10. Agreement with indicated comment disposition(s)
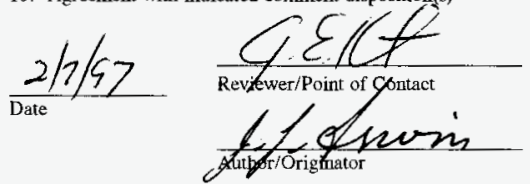

11. CLOSED
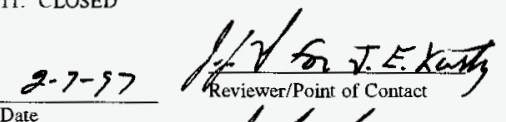

heviewer/Point of Contact

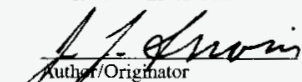

Origitiator

\begin{tabular}{|c|c|c|c|c|}
\hline $\begin{array}{l}12 . \\
\text { Item }\end{array}$ & $\begin{array}{l}\text { 13. Comment(s)/Discrepancy(s) (Provide technical jistification for the comment and } \\
\text { detailed recommendation of the action required to correct/ resolve the discrepancy/problem } \\
\text { indicated.) }\end{array}$ & $\begin{array}{l}14 . \\
\text { Hold } \\
\text { Point }\end{array}$ & 15. Disposition (Provide justification if NOT accepted.) & $\begin{array}{l}16 . \\
\text { Stans }\end{array}$ \\
\hline I & $\begin{array}{l}\text { H-1-82103: Wall section by PM-6A portal monitor needs to be removed. The PM- } \\
6 \mathrm{~A} \text { is a walkthru type monitor. Needs to be open front/rear for passage. }\end{array}$ & & $\begin{array}{l}\text { The type of PCM shall be verified and appropriate changes will be } \\
\text { made to the facility. }\end{array}$ & $\mathrm{OK}$ \\
\hline 2 & $\begin{array}{l}\text { H-1-82103: Radcon office. Request wail opening on north side by door } 31 \text { to allow } \\
\text { dosimetry processing during ingress/egress. Or make door } 31 \text { a half type door. }\end{array}$ & & A horizontal sliding pass-through window shall be provided. & $\mathrm{OK}$ \\
\hline 3 & H-1-82104: Question? Is equipment hood adjustable over the cask? & & Yes, bood will cover MCO top with holes for valve ventilation. & OK \\
\hline
\end{tabular}

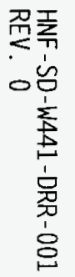




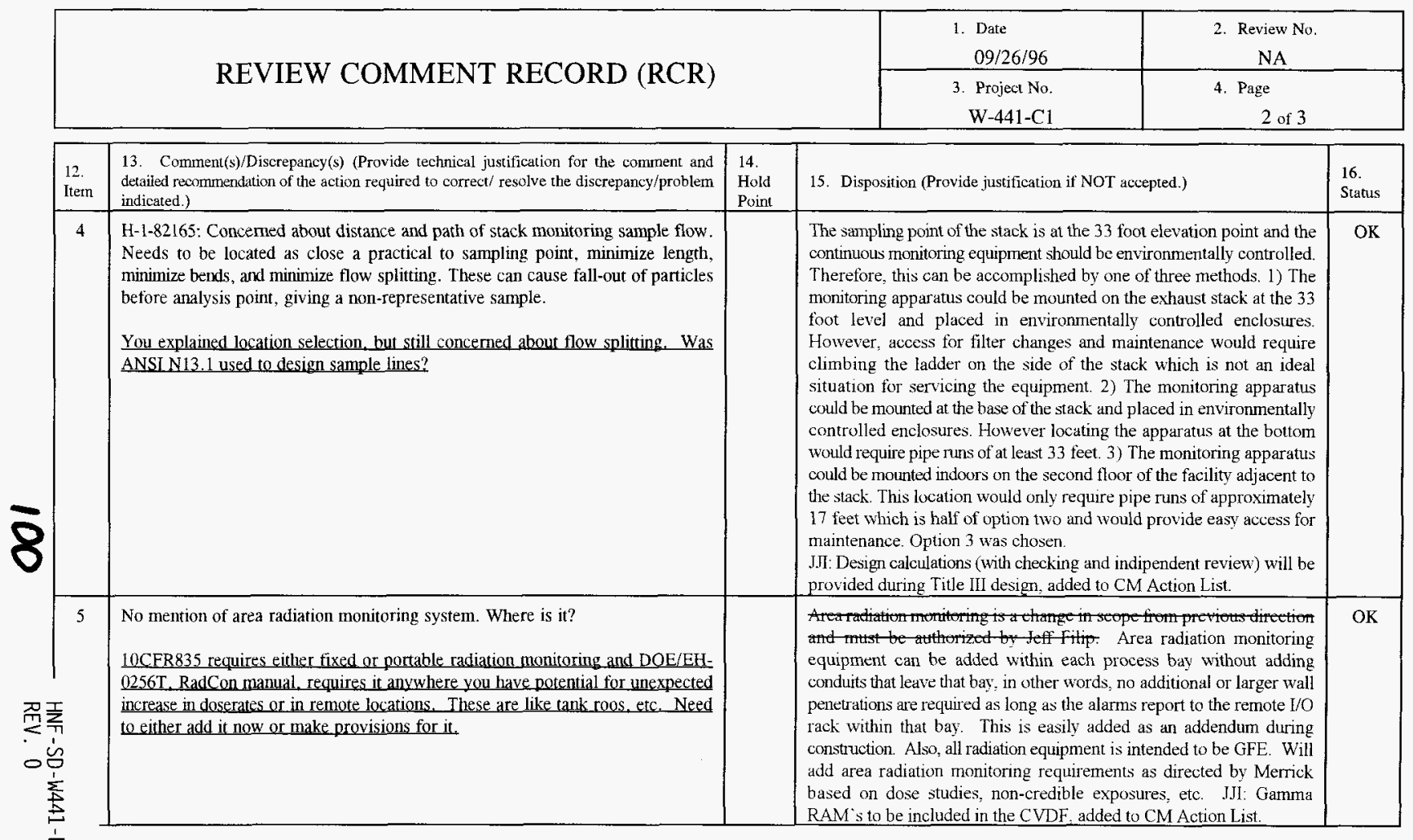




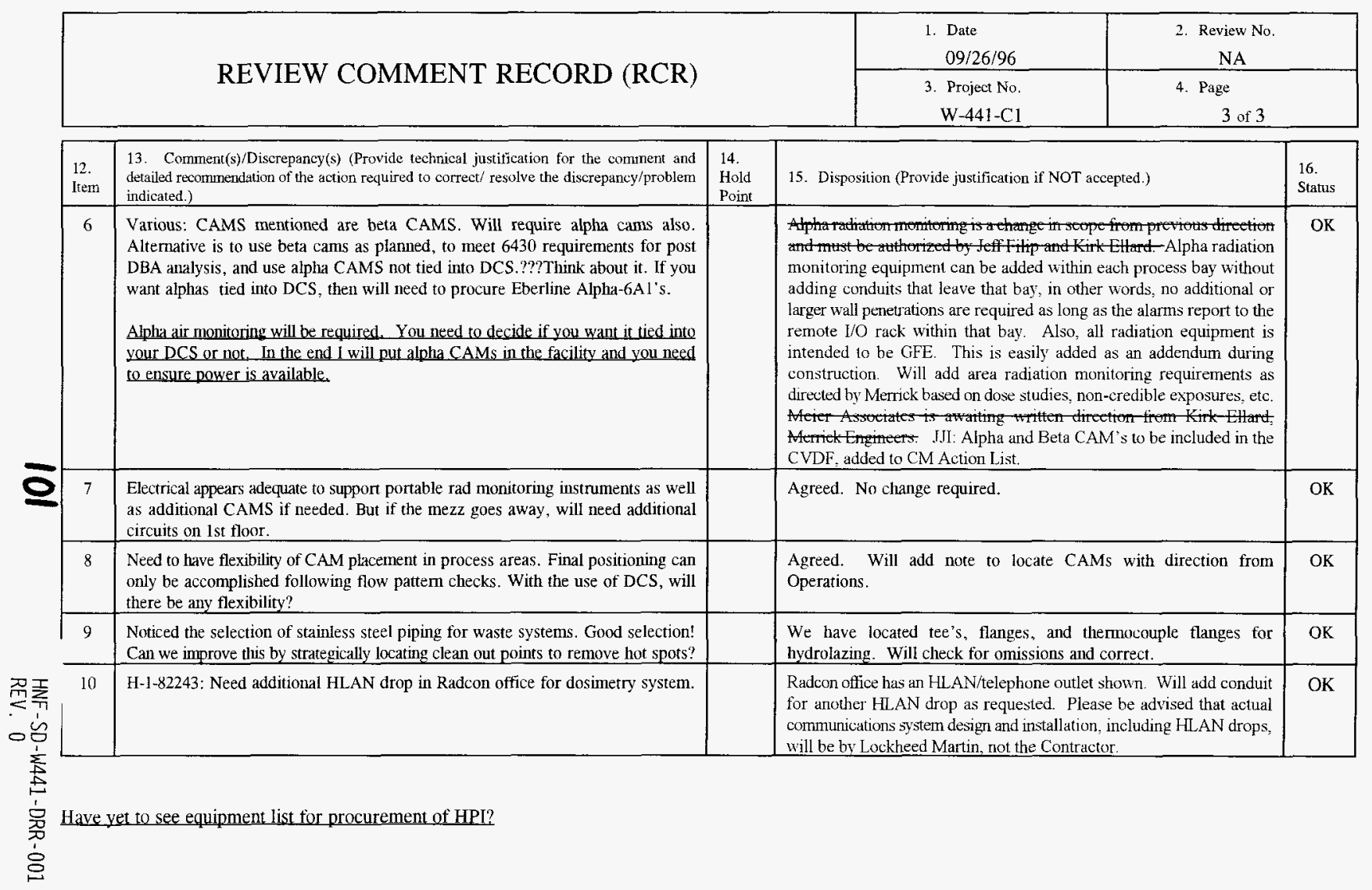




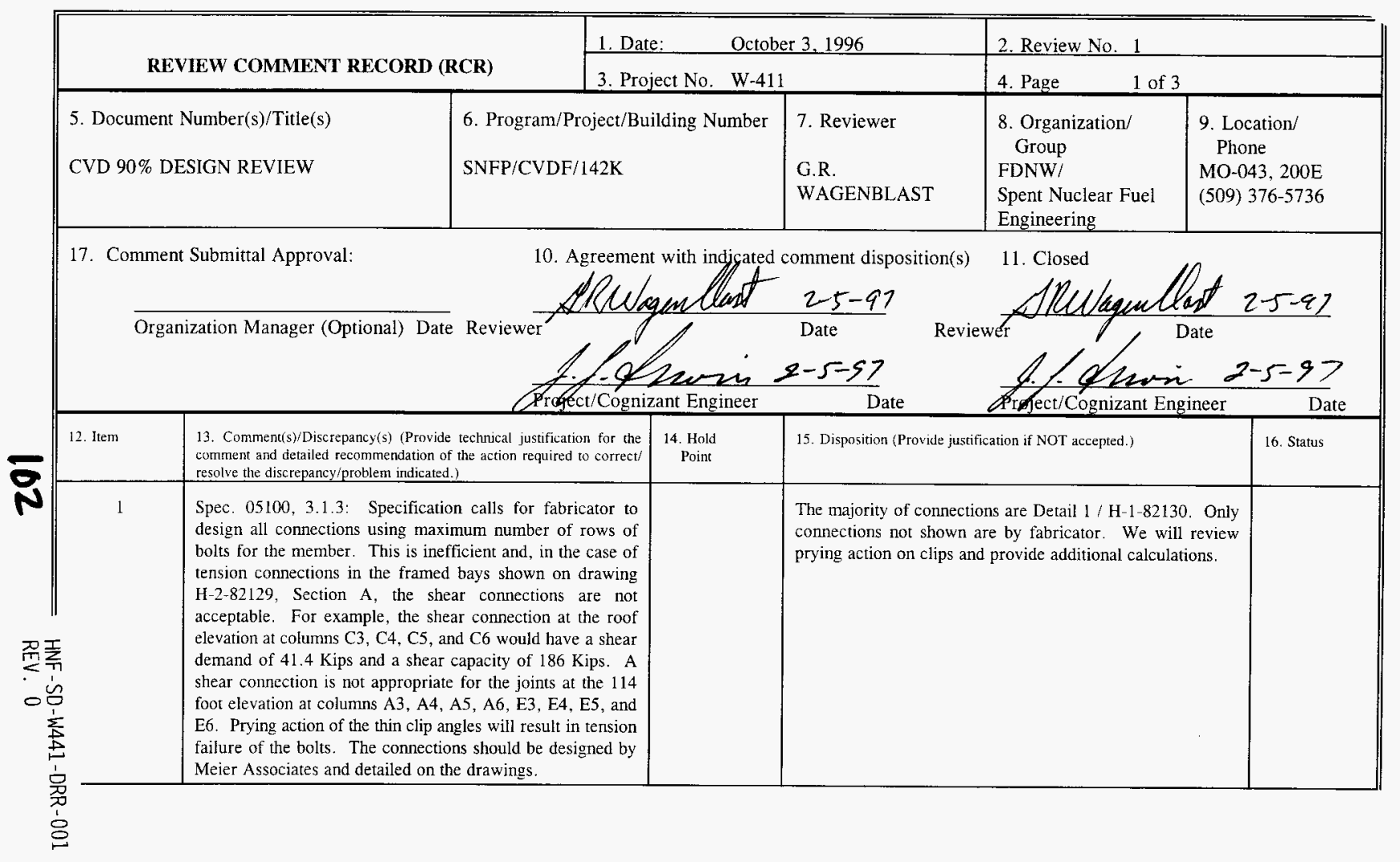




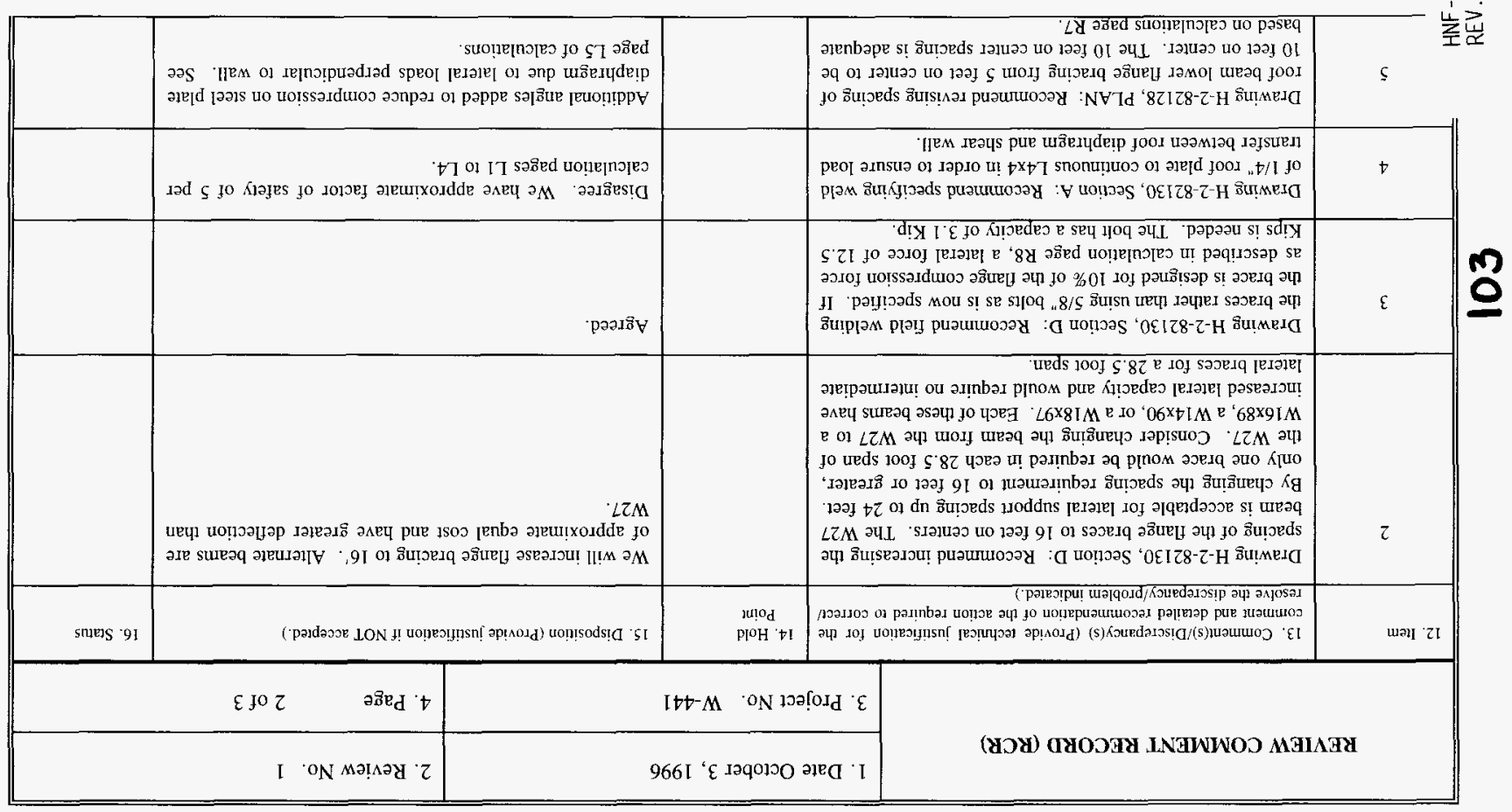




\begin{tabular}{|c|c|c|c|c|}
\hline \multirow{2}{*}{ REVIEW COMMENT RECORD (RCR) } & \multicolumn{2}{|c|}{ 1. Date October 3, 1996} & \multirow{2}{*}{\multicolumn{2}{|c|}{$\begin{array}{l}\text { 2. Review No. } 1 \\
\text { 4. Page } 3 \text { of } 3\end{array}$}} \\
\hline & \multicolumn{2}{|c|}{ 3. Project No. W-441 } & & \\
\hline $\begin{array}{l}\text { 13. Comment(s)/Discrepancy(s) (Provide technical justification for the } \\
\text { comment and detailed recoymendacion of ine action required to correcu } \\
\text { resolve the discrepancy/problem indicated.) }\end{array}$ & $\begin{array}{l}\text { 14. Hold } \\
\text { Point }\end{array}$ & \multicolumn{2}{|c|}{ 15. Disposition (Provide justification if NOT accepted.) } & 16. Status \\
\hline $\begin{array}{l}\text { Drawing } H-2-82130 \text {, Section C: Recommend replacing } \\
\text { L6x4x1/4 continuous angle with a plate (or turn the } \\
\text { angle such that the vertical leg points down and weld on } \\
\text { the heal of the angle) so that the weld to the wall plate is } \\
\text { in line with the weld to the top of the flange of the roof } \\
\text { beam. As it is now detailed, the lateral load on the weld } \\
\text { at the top of the leg of the angle will overstress the angle } \\
\text { leg in bending. } \\
\text { Revise the weld callout. Cannot weld on } 3 \text { sides of a } \\
\text { continuous angle. }\end{array}$ & & \multicolumn{2}{|c|}{ Agreed. Will turn angle upside down. } & \\
\hline $\begin{array}{l}\text { Structural Calculation pages } \mathrm{L} 7 \text { to } \mathrm{L} 12 \text { : Computer } \\
\text { model inaccurately specifies member end release } \\
\text { conditions and beam orientation conditions. Rerun } \\
\text { frame calculations. }\end{array}$ & & \multicolumn{2}{|l|}{ Agreed. } & \\
\hline $\begin{array}{l}\text { Drawing H-2-82126, Section A: Recommend deleting } \\
\text { column flange doubler plate. I found no requirement for } \\
\text { the doubler in the calculations. }\end{array}$ & & \multicolumn{2}{|c|}{$\begin{array}{l}\text { Plate is for shielding requirements and is not considered } \\
\text { in structural calculations. }\end{array}$} & \\
\hline $\begin{array}{l}\text { Structural Calculation page L12: Columns A3, A4, A5, A6, } \\
\text { E3, E4. E5, and E6 could have as much as } 104 \text { Kips uplift } \\
\text { combinined with } 149 \text { Kips shear during the tornado loading. } \\
\text { There are no calculations to show that the column base plate } \\
\text { and anchor bolts can withstand these loads. Provide } \\
\text { calculations for all collumn hases. }\end{array}$ & & \multicolumn{2}{|l|}{ Agreed. } & \\
\hline
\end{tabular}




\begin{tabular}{|c|l|l|}
\hline \multirow{2}{*}{ REVIEW COMMENT RECORD (RCR) } & $\begin{array}{l}\text { 1. Date } \\
09 / 27 / 96\end{array}$ & Review No. \\
\cline { 2 - 4 } & $\begin{array}{c}\text { 3. Project No. } \\
\text { W-441-C1 }\end{array}$ & \begin{tabular}{l} 
4. Page \\
\hline
\end{tabular} \\
\hline
\end{tabular}

\begin{tabular}{|l|l|l|l|l|}
\hline 5. Document Number(s)/Title(s) & $\begin{array}{l}\text { 6. Program/Project/ } \\
\text { Building Number } \\
\text { SNFP/CVDF/142K }\end{array}$ & 7. Reviewer & 8. Organization/Group \\
Project W-441-Cl / CVD Facility & Butchins & Cog Engineering \\
\hline
\end{tabular}

17. Comment Submittal Approval:

Organization Manager (Optional)
10. Agreement with indicated comment disposition(s)

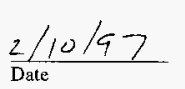

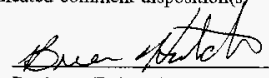

Reviewer/Point of Contact

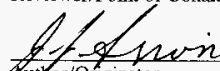

$\dot{n}$

\section{is}

iginator

\begin{tabular}{|c|c|c|c|c|c|}
\hline & $\begin{array}{l}12 . \\
\text { Item }\end{array}$ & $\begin{array}{l}\text { 13. Comment(s)/Discrepancy(s) (Provide technical justification for the comment and } \\
\text { detailed recommendation of the action required to correcu/ resolve the discrepancy/problem } \\
\text { indicated.) }\end{array}$ & $\begin{array}{l}14 . \\
\text { Hold } \\
\text { Point }\end{array}$ & 15. Disposition (Provide justification if NOT accepted.) & $\begin{array}{l}16 . \\
\text { Status }\end{array}$ \\
\hline \multirow{4}{*}{ 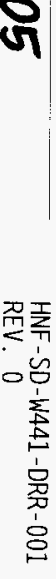 } & 1 & $\begin{array}{l}\text { Construction Spec, section } 15400.3 .5 .1 \text { : Hot and cold water according to Uniform } \\
\text { Plumbing Code (UPC) Section } 318 \text { (b) (6) "Water Piping - Upon Completion of } \\
\text { a section or the entire hot and cold water supply system, it shall be tested and } \\
\text { proved tight under a water pressure not less than the working pressure under } \\
\text { which it to be used. The water used for tests shall be obtained from a potable } \\
\text { source of supply. A } 50 \text { psi air pressure may be substituted for the water test. In } \\
\text { either method of test, the piping shall withstand the test without leaking for a } \\
\text { period of not less than } 15 \text { minutes." } \\
\text { Your } 100 \text { psi for } 1 \text { hour is excessive, system pressure for } 15 \text { minutes is } \\
\text { acceptable. }\end{array}$ & $\mathrm{N}$ & $\begin{array}{l}\text { Maximum system pressure is } 60 \text { psig. Test pressure will be changed } \\
\text { to } 68 \mathrm{Rsi} \text {, duration will be changed to } 15 \text { minutes. } \\
\text { JJ1: Pressure will be specified at } 75 \text { psig, max. }\end{array}$ & \\
\hline & 2 & $\begin{array}{l}\text { Constnuction Spec, section } 15400 \text {, Need the flow rate requirements for potable } \\
\text { water for determining if the current distribution system can meet the need and to } \\
\text { confirm } 1-1 / 2 \text { " piping size will meet the needs. Current system is marginal. }\end{array}$ & $Y$ & $\begin{array}{l}\text { Peak flow should not exceed } 20 \text { GPM, normal flow } 5 \text { to } 10 \text { GPM. } \\
\text { This does not belong in this section. Water flow calculations will be } \\
\text { submitted. }\end{array}$ & \\
\hline & 3 & $\begin{array}{l}\text { Construction Spec, section } 15400, \text { The connection and flow data mentioned in } \\
\text { comment } 2 \text { will need approval by the Washington State Department of Health } \\
\text { Drinking Water Division. }\end{array}$ & $\mathrm{Y}$ & $\begin{array}{l}\text { Eustomer responsibitity. JJI: Water data will be submitted by the } \\
\text { Construction manager and applicable permits will be requested. }\end{array}$ & \\
\hline & 4 & $\begin{array}{l}\text { Drawing } \mathrm{H}-1-82(194 \text {, detail } 2 \text { : use true union ball valves instead of a ball valve and } \\
\text { a union to reduce the number of fittings and ease of valve replacement in the future } \\
\text { if needed. }\end{array}$ & $\mathrm{N}$ & Agreed. & \\
\hline
\end{tabular}

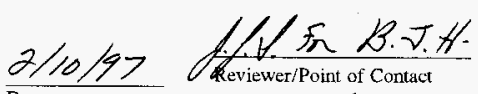

Date

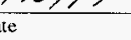

Reviewer/Point of Contaci

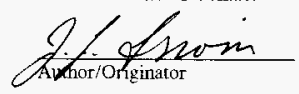

-6400-090.1 (03/92) WEF011 


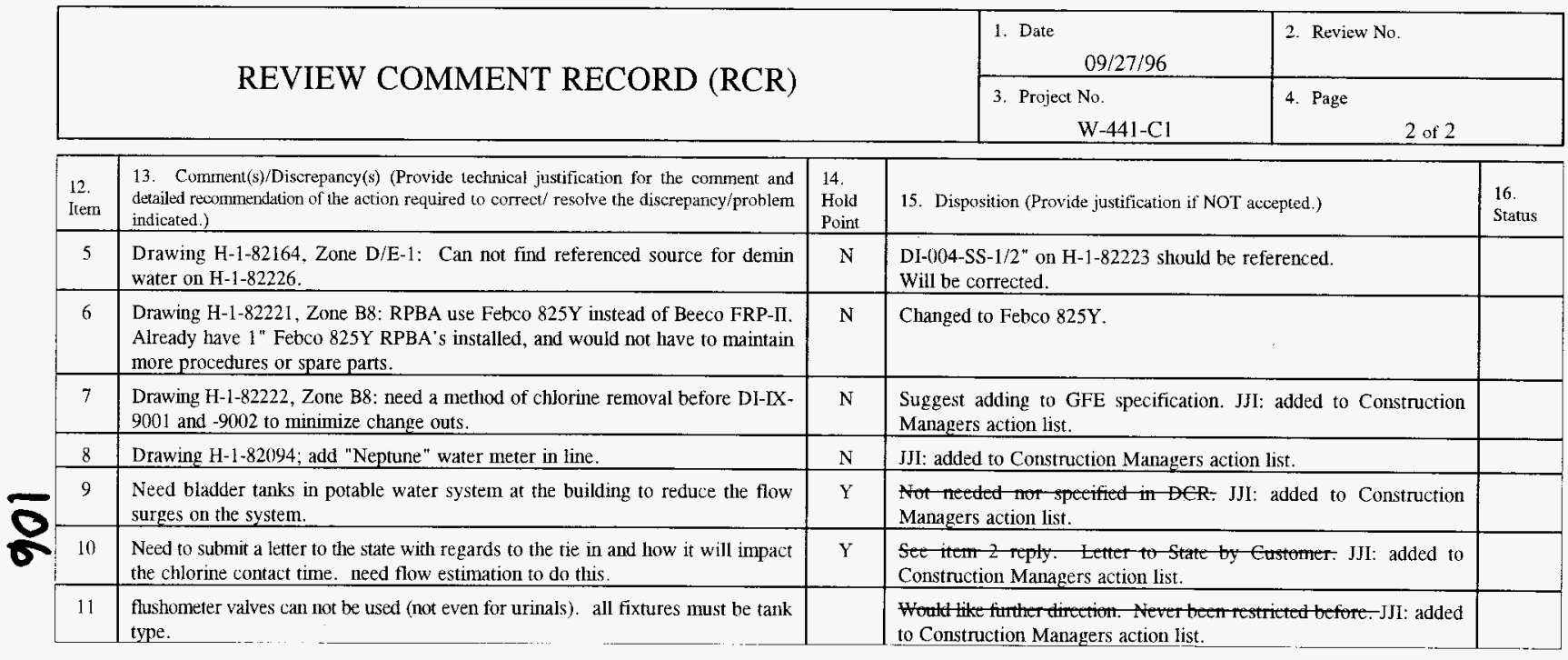

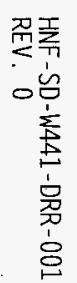




\begin{tabular}{|l|l|l|l|}
\hline \multirow{2}{*}{ REVIEW COMMENT RECORD (RCR) } & 1. Date Review No. & $10 / 11 / 96$ \\
\cline { 2 - 4 } & $\begin{array}{c}\text { 3. Project No. } \\
\text { W-441-C1 }\end{array}$ & 4. Page \\
\hline
\end{tabular}

\begin{tabular}{|l|l|l|l|l|}
\hline 5. Document Number(s)/Title(s) & $\begin{array}{l}\text { 6. Program/Project/ } \\
\text { Building Number } \\
\text { SNF/CVDF/142K }\end{array}$ & 7. Reviewer & 8. Organization/Group \\
$\begin{array}{l}\text { Cold Vacuum Drying Facility 90\% Design } \\
\text { Review }\end{array}$ & Deny & SNFP Safety \\
\hline
\end{tabular}

17. Comment Submittal Approval:

Organization Manager (Optional)

10. Agreement with indicated comment disposition(s)

10. Agreement with indicated comment disposition(s)
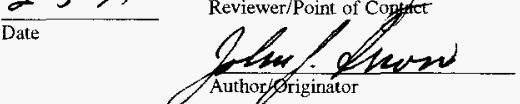

11. CLOSED

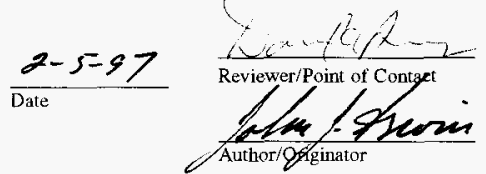

\begin{tabular}{|c|c|c|c|c|}
\hline $\begin{array}{l}12 . \\
\text { Item }\end{array}$ & $\begin{array}{l}\text { 13. Comment(s)/Discrepancy(s) (Provide technical justification for the comment and } \\
\text { detailed recommendation of the action required to correct/resolve the diserepancy/problem } \\
\text { indicated.) }\end{array}$ & $\begin{array}{l}14 . \\
\text { Hold } \\
\text { Point }\end{array}$ & 15. Disposition (Provide justification if NOT accepted.) & $\begin{array}{l}16 . \\
\text { Status }\end{array}$ \\
\hline 1. & $\begin{array}{l}\text { General - Hard ducting the MCO rupture disk/relief device to the Process Hood } \\
\text { ducting or the with the Process vent ducting or providing a separate HEPA filter. } \\
\text { Include a backdraft damper in the Process Hood ducting such that the process vents } \\
\text { or MCO vent would not vent back in to the bay if the fans stop ruming. }\end{array}$ & & $\begin{array}{l}\text { 1. MCO rupture will be directly into the process hood duct.. } \\
\text { 2. Repiped process vent to down stream of isolation damper and added } \\
\text { HEPA to process vent line to prevent pressure buildup. }\end{array}$ & \\
\hline 2. & $\begin{array}{l}\text { General - Safety-Class hydrogen deflagration/detonation prevention system design } \\
\text { along with the safe shutdown design of the vacuum purnping system for all types of } \\
\text { system transients and failures. Some type of failure modes and effects analysis } \\
\text { (FMEA) needs to be done to ensure design satisfies safe shutdown criteria. }\end{array}$ & & Described in System Description. FMEA to be provided by client. & \\
\hline 3. & $\begin{array}{l}\text { General - Safety-Class criticality control design for the Liquid Waste System. This } \\
\text { includes a geometrically safe receiver tank and double contingency controls on all } \\
\text { transfers from the tank. Note: the filter and ion exchange module and associated } \\
\text { shielded containers may require some criticality analysis for liquid breaks that would } \\
\text { flood the containers and cause a criticality concern. }\end{array}$ & & Agreed. & \\
\hline 4. & $\begin{array}{l}\text { General - Identification of support system requirements (e.g instrumentation, } \\
\text { control systems, instrumentation \& control power (UPSs), etc.) that may be required } \\
\text { to accomplish the safety-class control functions above. These requirements have } \\
\text { not yet been identified. }\end{array}$ & & $\begin{array}{l}\text { JJI: A safety class inert gas injection system will be proposed by the } \\
\text { Design Authority. Design will be implemented by the Design Agent. } \\
\text { Added to the CM Action List. }\end{array}$ & \\
\hline 5. & $\begin{array}{l}\text { General - Tomado wind doors for Process bays and Process Water Tank Room are } \\
\text { required. }\end{array}$ & & Agreed. & \\
\hline
\end{tabular}




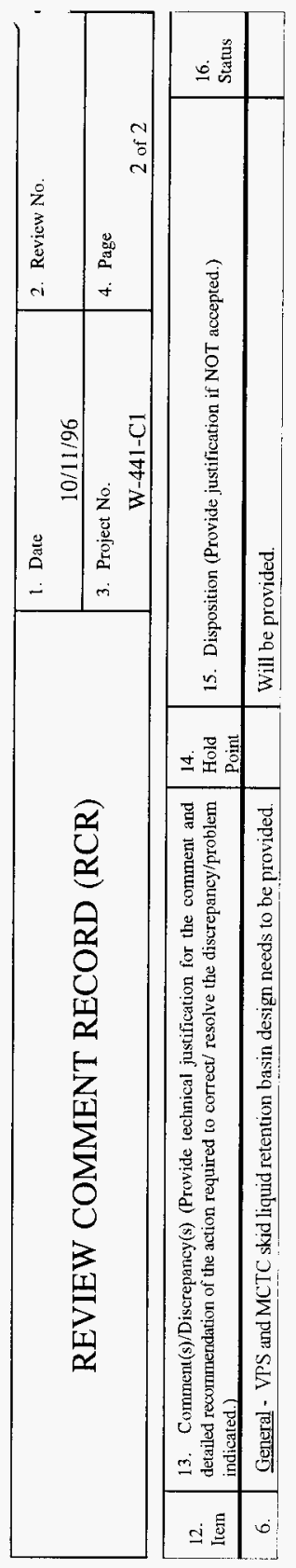

HNF-SD-W441-DRR-001 REV. 0 


\begin{tabular}{|l|l|l|l|}
\hline \multirow{2}{*}{ REVIEW COMMENT RECORD (RCR) } & $\begin{array}{l}\text { 1. Date } \\
\text { 2. Review No. }\end{array}$ & $\begin{array}{c}\text { 3. Project No. } \\
\text { W-441-C1 }\end{array}$ \\
\cline { 2 - 4 }
\end{tabular}

\begin{tabular}{|l|l|l|l|l|}
\hline 5. Document Number(s)/Title(s) & $\begin{array}{l}\text { 6. Program/Project/ } \\
\text { Building Number } \\
\text { SNFP/CVDF/142K }\end{array}$ & 7. Reviewer & 8. Organization/Group \\
$\begin{array}{l}\text { CVDF 90\% Design Review Construction Spec } \\
\text { and Drawing Package }\end{array}$ & SNF/KBE/COG ENG & MO-402/13/100K \\
\hline
\end{tabular}

17. Comment Submittal Approval:

Organization Manager (Optional)
10. Agreement with indicated comment disposition(s)

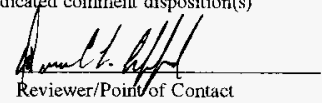

\begin{tabular}{|c|c|c|c|c|c|}
\hline & & ganization Manager (Optional) & & ewer/Point of $\mathrm{Co}$ & \\
\hline & $\begin{array}{l}12 . \\
\text { Item }\end{array}$ & $\begin{array}{l}\text { 13. Comment(s)/Discrepancy(s) (Provide technical justification for the comment and } \\
\text { decailed recommendation of the action required to correct/ resolve the discrepancy/problem } \\
\text { indicated.) }\end{array}$ & $\begin{array}{l}\text { 14. } \\
\text { Hold } \\
\text { Point }\end{array}$ & 15. Disposition (Provide justification if NOT accepted.) & $\begin{array}{l}16 . \\
\text { Status }\end{array}$ \\
\hline & 1 & $\begin{array}{l}\text { Note this is very cursony review since so much of the detail information is } \\
\text { still not in the package. } \\
\text { Many classes of support drawings were not provided. } \\
\text { General physical plant drawing note---Insufficient parking/access apron for } \\
\text { tank access and possible IX access for north equip room. Suggest a } 20 \mathrm{ft} \\
\text { wide apron on north side. Need room for crane and trailer. Apron on W } \\
\text { and S sides should also be wide enough to carry equip to west side, EG } \\
\text { chillers, tanks, pump trucks. Access does not look to be sufficient for } \\
\text { septic pumpout with currently used trucks. }\end{array}$ & & $\begin{array}{l}\text { Will be revicwed and evatuated. JJ: } 20 \mathrm{ft} \text {. Concrete apron } \\
\text { added to north side of the CVDF for access to changeout IXM. } \\
\text { IXM will be transferred to and from the CVDF through a roof } \\
\text { hatch. } 20 \mathrm{ft} \text { wide gravel road added around the north, west and } \\
\text { south side of the CVDF for equipment access. Gravel road has } \\
25 \mathrm{ft} \text { min. Turn radius. }\end{array}$ & $O K$ \\
\hline$\sum_{0}$ & 2 & $\begin{array}{l}\text { General --- Drain detail does not show elevations, Tank entry for septic } \\
\text { is shown but drain detail sheets were not included }\end{array}$ & & See Detail 4 on H-1-82229. & or \\
\hline $\begin{array}{l}\frac{1}{2} \\
\stackrel{D}{t} \\
\dot{0} \\
\dot{0}\end{array}$ & 3 & $\begin{array}{l}\text { DWG } 82106 \text { shows a rollup door on North side of the North tank } \\
\text { equipment bay. This side has the least vehicle access. Equipment } \\
\text { servicing is recommended by pacing the rollup door on the East side and } \\
\text { the personnel door on the north side. }\end{array}$ & & $\begin{array}{l}\text { No. Shictding would not be provided if door is relocated. JJI: } \\
\text { roof hatch has been added to change out the IXM from the tank } \\
\text { room. }\end{array}$ & or \\
\hline ᄋ & 4 & $\begin{array}{l}\text { DWG } 82124 \text { Detail } 16 \text { for footing for tank is not called out on DWG } \\
82121\end{array}$ & & $\begin{array}{l}\text { Đesign is not complete for this section. JJ: changes made prior } \\
\text { to rev. } 0 \text { release. }\end{array}$ & $O K$ \\
\hline
\end{tabular}

$-6400-090.1(03 / 92)$ WEF011

11. CLOSED

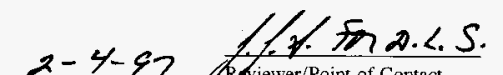

Dato

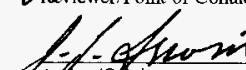
Slatus

Will be revicwed and evaluated. JJI: $20 \mathrm{ft}$. Concrete apron eut LXM the CVDF through a roof uth side of the CVDF for equipment access. Gravel road has rev. 0 release. 


\begin{tabular}{|l|l|l|}
\hline \multirow{2}{*}{ REVIEW COMMENT RECORD (RCR) } & 1. Date & Review No. \\
\cline { 2 - 3 } & $\begin{array}{c}\text { 3. Project No. } \\
\text { W-441-C1 }\end{array}$ & $\begin{array}{l}4 . \text { Page } \\
2\end{array}$ \\
\hline
\end{tabular}

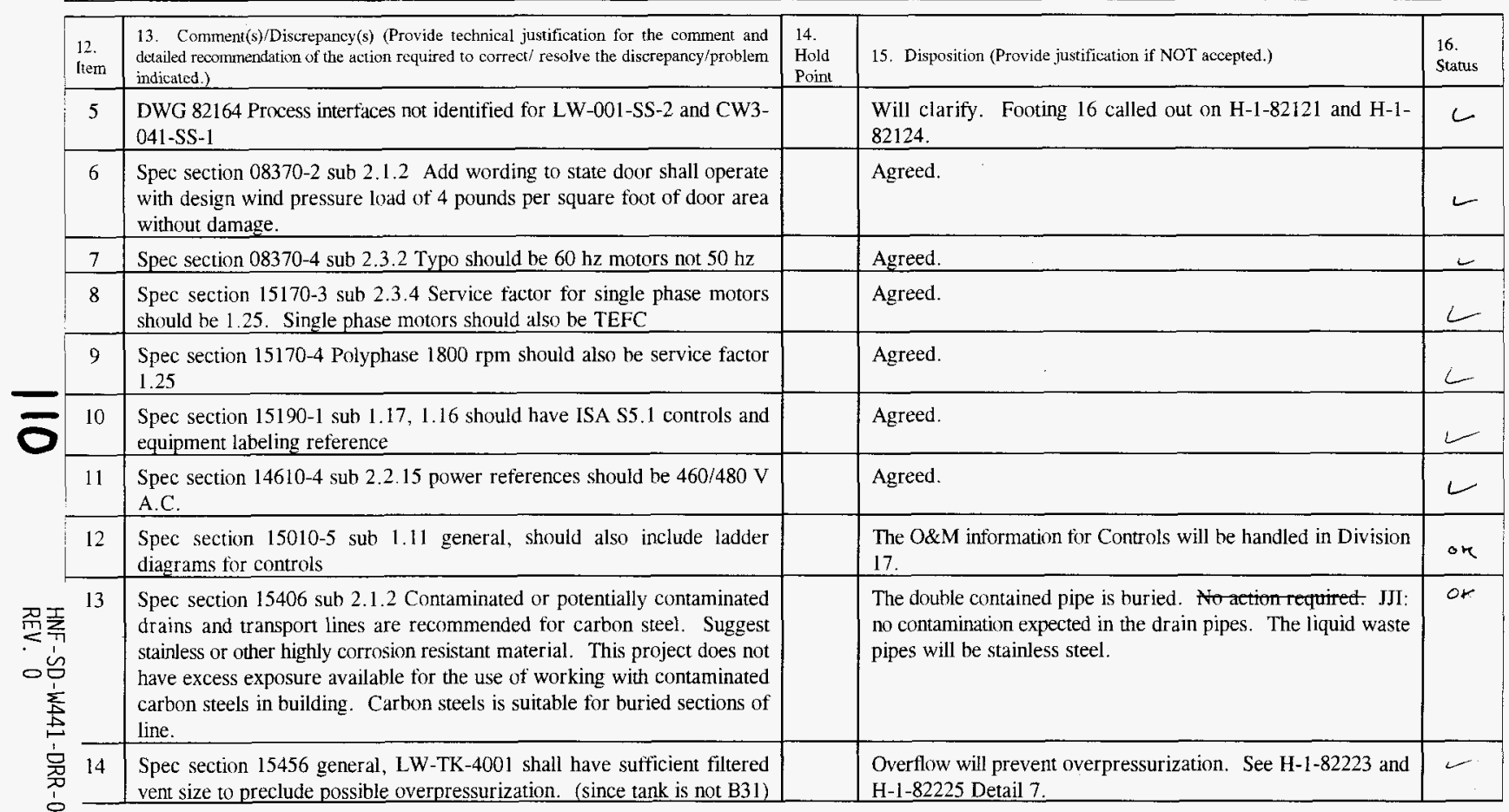




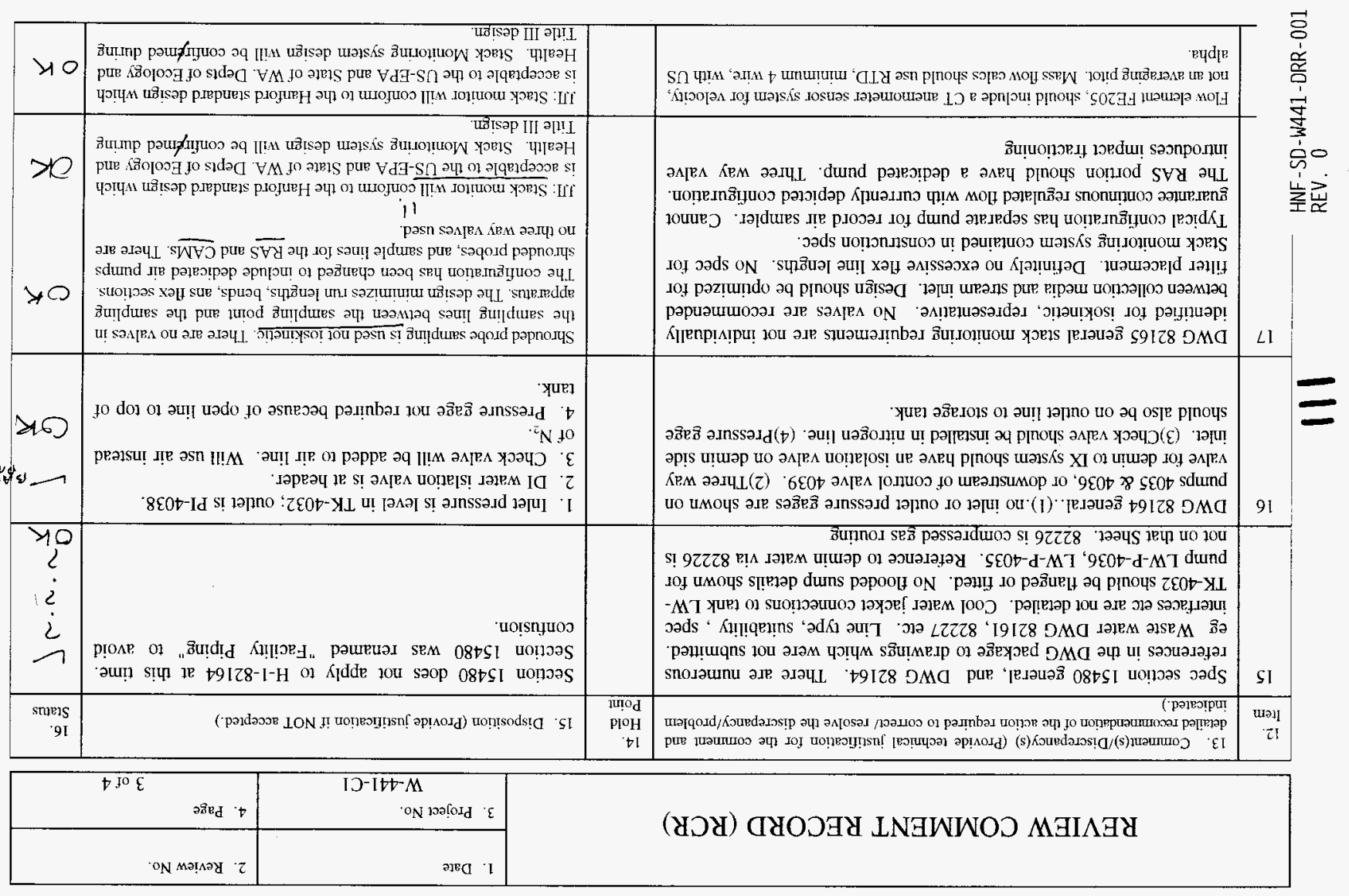




\begin{tabular}{|l|l|l|}
\hline \multirow{2}{*}{ REVIEW COMMENT RECORD (RCR) } & 1. Date & Review No. \\
\cline { 2 - 4 } & $\begin{array}{l}\text { 3. Project No. } \\
\text { W-441-Cl }\end{array}$ & 4. Page \\
\hline
\end{tabular}

\begin{tabular}{|c|c|c|c|c|}
\hline $\begin{array}{l}12 . \\
\text { Item }\end{array}$ & $\begin{array}{l}\text { 13. Comment(s)/Discrepancy(s) (Provide technical justification for the comment and } \\
\text { detailed recommendation of the action required to correct/ resolve the discrepancy/problem } \\
\text { indicated.) }\end{array}$ & $\begin{array}{l}14 . \\
\text { Hold } \\
\text { Point }\end{array}$ & 15. Disposition (Provide justification if NOT accepted.) & $\begin{array}{l}16 . \\
\text { Status }\end{array}$ \\
\hline 19 & $\begin{array}{l}\text { DWG } 82192 \text { Isolation damper should be installed between Process vent and room } \\
\text { hood. In the event of a gas generating condition this now would vent to the } \\
\text { unfiltered to the bay hood. }\end{array}$ & & Agreed. & $\sim$ \\
\hline 20 & $\begin{array}{l}\text { DWG } 82194 \text { et. al. Flow numbers through doorways, rollup doors etc should be } \\
\text { indicated with the doors in the estimated flow condition. }\end{array}$ & & JII: Agreed, will be specified in the HVAC claculation report. & L \\
\hline 21 & $\begin{array}{l}\text { DWG } 82195 \& 82196,82203 \text { etc and drain drawings do not show condensate drain } \\
\text { return lines for chilled water system stages. Pan is shown in } 82204 \text { but routing of } \\
\text { line is not }\end{array}$ & & JII: condensate drain lines will be detailed in Title III design. & \\
\hline 22 & $\begin{array}{l}\text { Spec } 15682 \text {---recommend chillers be compatible for a brine type system also. } \\
\text { Glycol preferred, if future heat content or waste water handling becomes an issue. }\end{array}$ & & $\begin{array}{l}\text { III: Will be evaluated in Title lll design, no specilic requirement for the } \\
\text { refrigerant was specified. }\end{array}$ & \\
\hline 23 & $\begin{array}{l}\text { DWG } 82198,82197,82199 \text {, and construction spec do not provide details on noise } \\
\text { and vibration dampening mounts/locations. Need more info. }\end{array}$ & & $\begin{array}{l}\text { Vibration isolation is specified with equipment requiring such. } \\
\text { Location of vibration isolators is specific to the actual equipment } \\
\text { funnished and will be determined based on equipment submittals. }\end{array}$ & $\mathcal{L}$ \\
\hline 24 & $\begin{array}{l}\text { DWG } 82206 \text { et al do not show the location of the instrument air regulator stations } \\
\text { ie damper controls supply ete. Also interlock logic diagram not identified for input } \\
\text { vs. control action }\end{array}$ & & $\begin{array}{l}\text { Locations of instrument air regulators is shown on Dwg. H-1-82222. } \\
\text { Interlock logic diagrams are not within the scope of Dwg. } 82206 \text {. }\end{array}$ & L \\
\hline 25 & $\begin{array}{l}\text { DWG } 82192 \text { and } 82206 \text {. Process bay general exhaust flow is depicted as } 5,660 \text { and } \\
12,450 \mathrm{scfm} \text { for the same line. }\end{array}$ & & $\begin{array}{l}\text { Dwg. } 82192-5660 \text { CFM is the general exhaust flow from the process } \\
\text { bays and tank room, only. Dwg. } 82206-12,450 \text { CFM is the total } \\
\text { general exhaust flow. }\end{array}$ & $L$ \\
\hline 26 & $\begin{array}{l}\text { DWG } 82222 \text {---does not identify the reference to the performance spec for IX T. } \\
\text { Hardness, cl2, Na replacement }\end{array}$ & & $\begin{array}{l}\text { IJI: will be } \\
\text { added to the Construction Managers Action List. }\end{array}$ & OK \\
\hline
\end{tabular}

6400-090.1 (03/92) WEF011 


\begin{tabular}{|c|c|c|}
\hline \multirow{2}{*}{ REVIEW COMMENT RECORD (RCR) } & $\begin{array}{l}\text { 1. Date } \\
10 / 11 / 96\end{array}$ & 2. Review No. \\
\hline & $\begin{array}{l}\text { 3. Project No. } \\
\text { W-441-C1 }\end{array}$ & 4. Page \\
\hline
\end{tabular}

\begin{tabular}{|l|l|l|l|l|}
\hline 5. Document Number(s)/Title(s) & $\begin{array}{l}\text { 6. Program/Project/ } \\
\text { Building Number } \\
\text { SNF/CVDF/142K }\end{array}$ & 7. Reviewer & Mike Silvia & Organization/Group \\
$\begin{array}{l}\text { Cold Vacuum Drying Facility 90\% Design } \\
\text { Review }\end{array}$ & IT Corp/EPA Permitting & $943-6728$ \\
\hline
\end{tabular}

17. Comment Submittal Approval:

Organization Manager (Optional)
10. Agreement with indicated comment disposition(s)

$$
\therefore,>3>
$$

Date

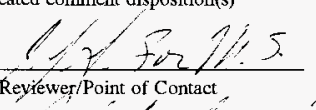

Reyiewer/Point of Contact

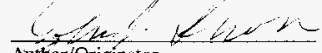

11. CLOSED

11. CLOSED

$\frac{1-7-7-7}{\text { Date }}$
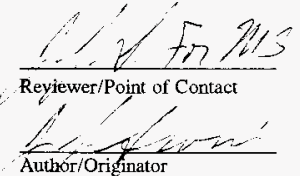

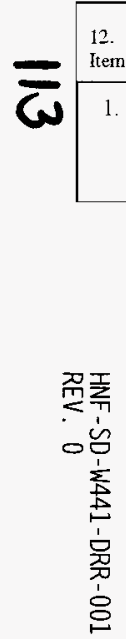

\begin{tabular}{|c|c|c|c|}
\hline $\begin{array}{l}\text { 13. Comment(s)/Discrepancy(s) (Provide technical justification for the comment and } \\
\text { detailed recommendation of the action required to correct/ resolve the discrepancy/problem } \\
\text { indicated.) }\end{array}$ & $\begin{array}{l}14 . \\
\text { Hold } \\
\text { Point }\end{array}$ & 15. Disposition (Provide justification if NOT accepted.) & $\begin{array}{l}16 . \\
\text { Status }\end{array}$ \\
\hline $\begin{array}{l}\text { H-1-82165, P\&ID Exhaust Stack Monitoring; Revise details on drawing to match } \\
\text { description provided in DOE-RL-9647, Rev, A, US. EPA Clean Air Act Notice of } \\
\text { Construction for the SNFP Cold Vacuum Drying Facility, Project W-441, 1996, see } \\
\text { section 3.3, Effluent Monitoring, pages } 39 \text { through } 45\end{array}$ & & III: The stack monitor as defined on $\mathrm{H}-1-82209$ compies with the NOC & ok \\
\hline
\end{tabular}




\section{REVIEW COMMENT RECORD (RCR)}

\begin{tabular}{|l|l|}
\hline 1. Date & 2. Review No. \\
\hline $\begin{array}{c}\text { 3. Project No. } \\
\text { W-441-Cl }\end{array}$ & 4. Page $\quad 1$ of 2 \\
\hline
\end{tabular}

\begin{tabular}{|c|c|c|c|c|}
\hline 5. Document Number(s):Title(s) & $\begin{array}{l}\text { 6. Program/Project: } \\
\text { Building Number }\end{array}$ & 7. Reviewer & 8. Organization/Group & 9. Location/Phone \\
\hline Cold Vacuum Drying Facility 90\% Design Review & $\mathrm{SNFP} / \mathrm{CVDF} / 142 \mathrm{~K}$ & Mark H. Brown & $\begin{array}{l}\text { FDNW/Acceptance } \\
\text { Inspection }\end{array}$ & $\mathrm{MO} 108 / 372-1611$ \\
\hline
\end{tabular}

17. Comment Submittal Approval

Organization Manager (Optional)
10. Agreement with indicated comment disposition(s)

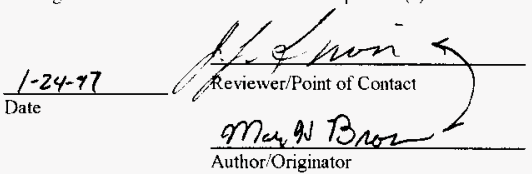

11. CLOSED

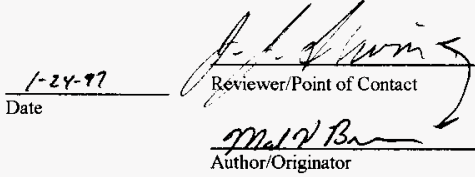

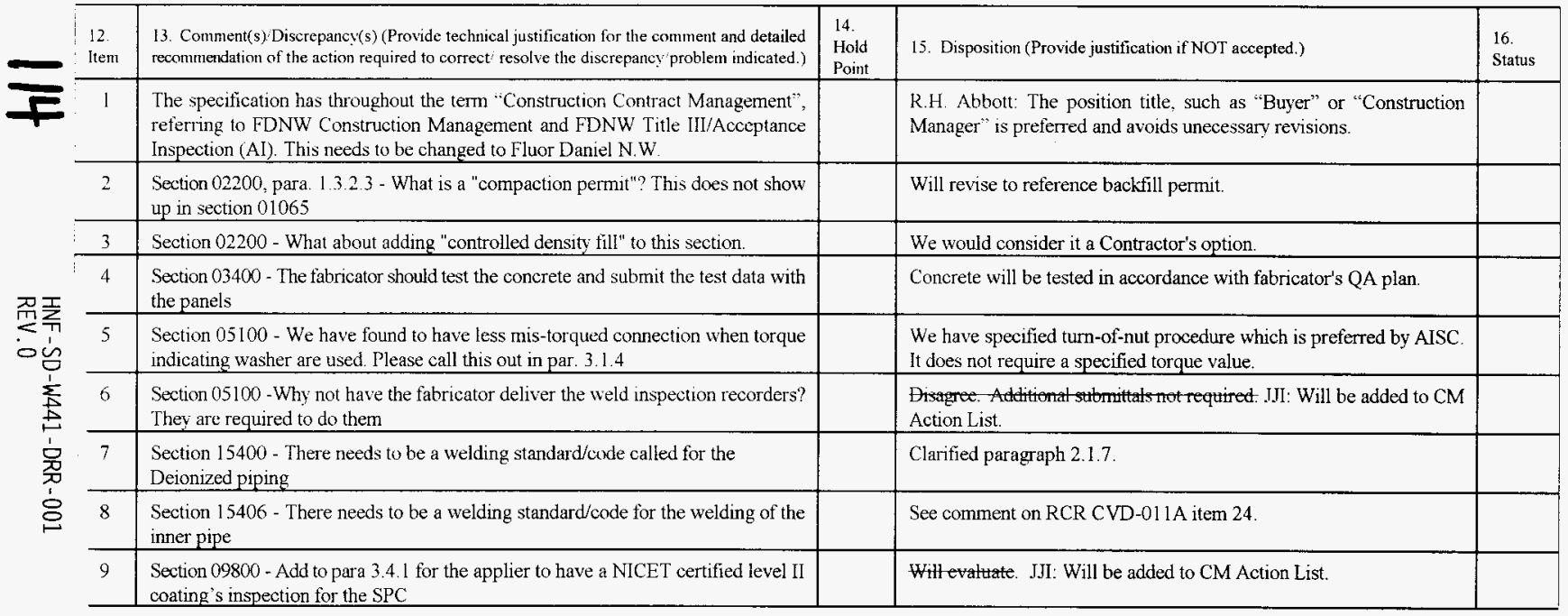

$-6400-090.1(03 / 92)$ WEF011 


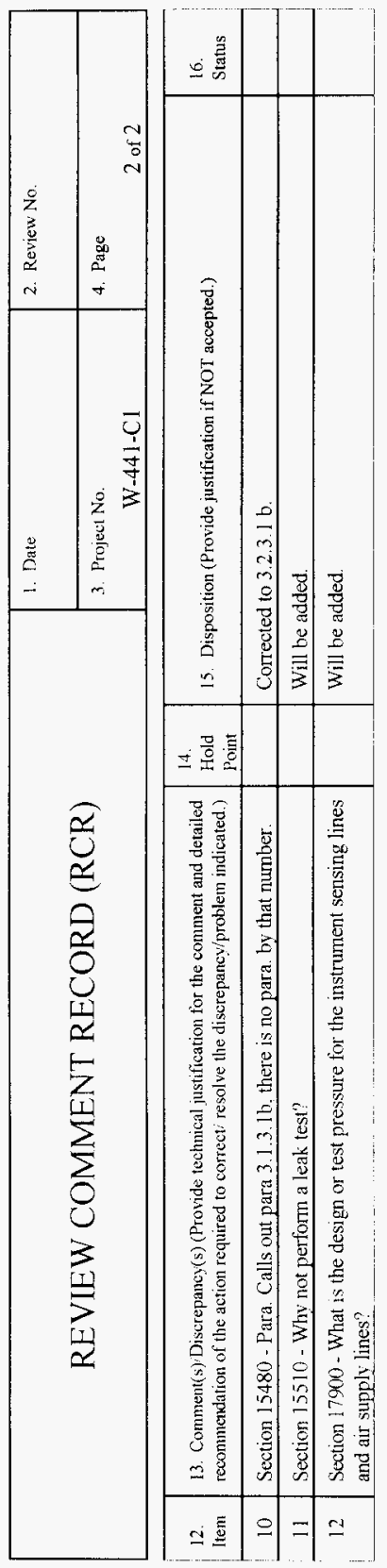

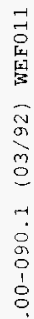

HNF - SD -W441 -DRR- 001

REV. 0 


\begin{tabular}{|l|l|l|l|}
\hline \multirow{2}{*}{ REVIEW COMMENT RECORD (RCR) } & 1. Datc & 2. Revicw No. \\
\cline { 2 - 4 } & 3. Project No. \\
W-441 & 4. Page \\
\hline
\end{tabular}

\begin{tabular}{|l|l|l|l|l|}
\hline 5. Document Number(s)/Titie(s) & $\begin{array}{l}\text { 6. Program/Project/ } \\
\text { Building Number } \\
\text { SNFP/CVDF/142K }\end{array}$ & 7. Reviewer & 8. Organization/Group \\
CVD Construction Spec. 90\% Review & James. Mathews & SNF Startup \\
\hline
\end{tabular}

17. Comment Submittal Approval:

Organization Manager (Optional)
10. Agreement with indicated comment disposition(s)

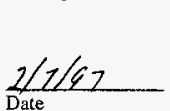

11. CLOSED
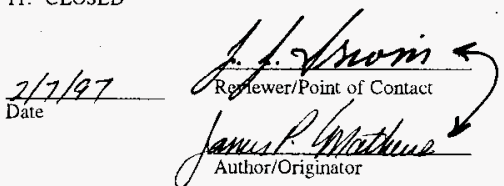

\begin{tabular}{|c|c|c|c|c|}
\hline $\begin{array}{l}12 . \\
\text { Itcen }\end{array}$ & $\begin{array}{l}\text { 13. Comment(s)/Discrepancy(s) (Provide technical justification for the comment and } \\
\text { detailed recommendation of the action required to correct/ resolve the discrepancy/problem } \\
\text { indicated.) }\end{array}$ & $\begin{array}{l}14 . \\
\text { Hold } \\
\text { Point }\end{array}$ & 15. Disposition (Provide justification if NOT accepted.) & $\begin{array}{l}16 . \\
\text { Status }\end{array}$ \\
\hline 1 & $\begin{array}{l}\text { Section } 01670 \text { Replace entirely the section as written. A Constructor, if } \\
\text { not a design authority, is generally not the appropriate agent to prepare a } \\
\text { System Acceptance Test Procedure as shown in the Appendix A format. } \\
\text { A Constructor would be expected to prepare Construction Acceptance Test } \\
\text { procedures and data sheets associated with component or sub-system level } \\
\text { tests, such as electrical resistance measurements, flushing, etc. }\end{array}$ & & R. Abbott: Generaily accounted for by CM revisions to 01670 . & \\
\hline $2 \mathrm{a}$ & $\begin{array}{l}\text { New Section } 01670 \text { TESTING, ACCEPTANCE, AND TURNOVER OF } \\
\text { STRUCTURES/SYSTEMS/COMPONENTS } \\
\text { PART } 1 \text { GENERAL } \\
\text { 1.1 References: Not used. }\end{array}$ & & R. Abbott: Generally accounted for by CM revisions to 01670 . & \\
\hline $2 b$ & $\begin{array}{l}\text { 1.2 Submittals: All Construction Acceptance Test (CAT) activities shall be } \\
\text { documented and test results submitted to Client Construction Manager for } \\
\text { acceptance within five (5) working days of actual test performance. }\end{array}$ & & R. Abbott: Generally accounted for by CM revisions to 01670 . & \\
\hline
\end{tabular}




\begin{tabular}{|l|l|l|}
\hline \multirow{2}{*}{ REVIEW COMMENT RECORD (RCR) } & 1. Date & $10-10-96$ \\
\cline { 2 - 4 } & 3. Project No. Review No. \\
W-441 & 4. Page \\
\hline
\end{tabular}

\begin{tabular}{|c|c|c|c|c|}
\hline $\begin{array}{l}12 . \\
\text { Item }\end{array}$ & $\begin{array}{l}\text { 13. Comment(s)/Discrepancy(s) (Provide technical justification for the comment and } \\
\text { detaiied recommendation of the action required to correct/ resolve the discrepancy/problem } \\
\text { indicated.) }\end{array}$ & $\begin{array}{l}14 . \\
\text { Hold } \\
\text { Point }\end{array}$ & 15. Disposition (Provide justification if NOT accepted.) & $\begin{array}{l}16 . \\
\text { Status }\end{array}$ \\
\hline $2 c$ & $\begin{array}{l}\text { 1.3 Summary: } \\
\text { 1.3.1 Required CATs are shown in column "CM" in Appendix (A) entitled } \\
\text { "TESTING INTERFACE DIAGRAM" (TID). The TID is issued and } \\
\text { controlled by the Integrating Contractor (IC) Startup Organization. Tests } \\
\text { specified in the TID may be in addition to, or may be duplicates of tests } \\
\text { specified in divisions } 15,16 \text {, and } 17 \text {. } \\
\text { 1.3.2 IC Startup personnel shall be notified approximately } 24 \text { hours prior } \\
\text { to performance of CATs which require Startup witness as identified in the } \\
\text { STARTUP column on the TID (appendix A). } \\
\text { Contractor or their subcontractor(s) who inspect, test, calibrate and } \\
\text { perform loop functional testing of instrumentation and controls including } \\
\text { computer based Distributed Control Systems shall demonstrate they are } \\
\text { qualified to perform the work by certifying that they have at least five } \\
\text { years of related experience and work history. }\end{array}$ & & R. Abbott: Generally accounted for by CM revisions to 01670 . & \\
\hline $2 d$ & $\begin{array}{l}\text { 1.3.4 Contractor shall schedule construction completion tests/inspections } \\
\text { and turnover of Structures, Systems and Components (SSC) to the IC } \\
\text { Startup organization in accordance with the requirements of the Cold } \\
\text { Vacuum Drying facility testing/turnover schedule prepared by the IC } \\
\text { Startup. } \\
\text { 1.3.5 Contractor or their subcontractor(s) shall perform inspection and } \\
\text { testing as shown on the Testing Interface Diagram (TID), Appendix X. } \\
\text { The inspection and testing shall be in accordance with Contract Drawings, } \\
\text { Specifications. Inspection Plans and Construction Test Procedures. }\end{array}$ & & R. Abbott: Generally accounted for by CM revisions to 01670 . & \\
\hline
\end{tabular}




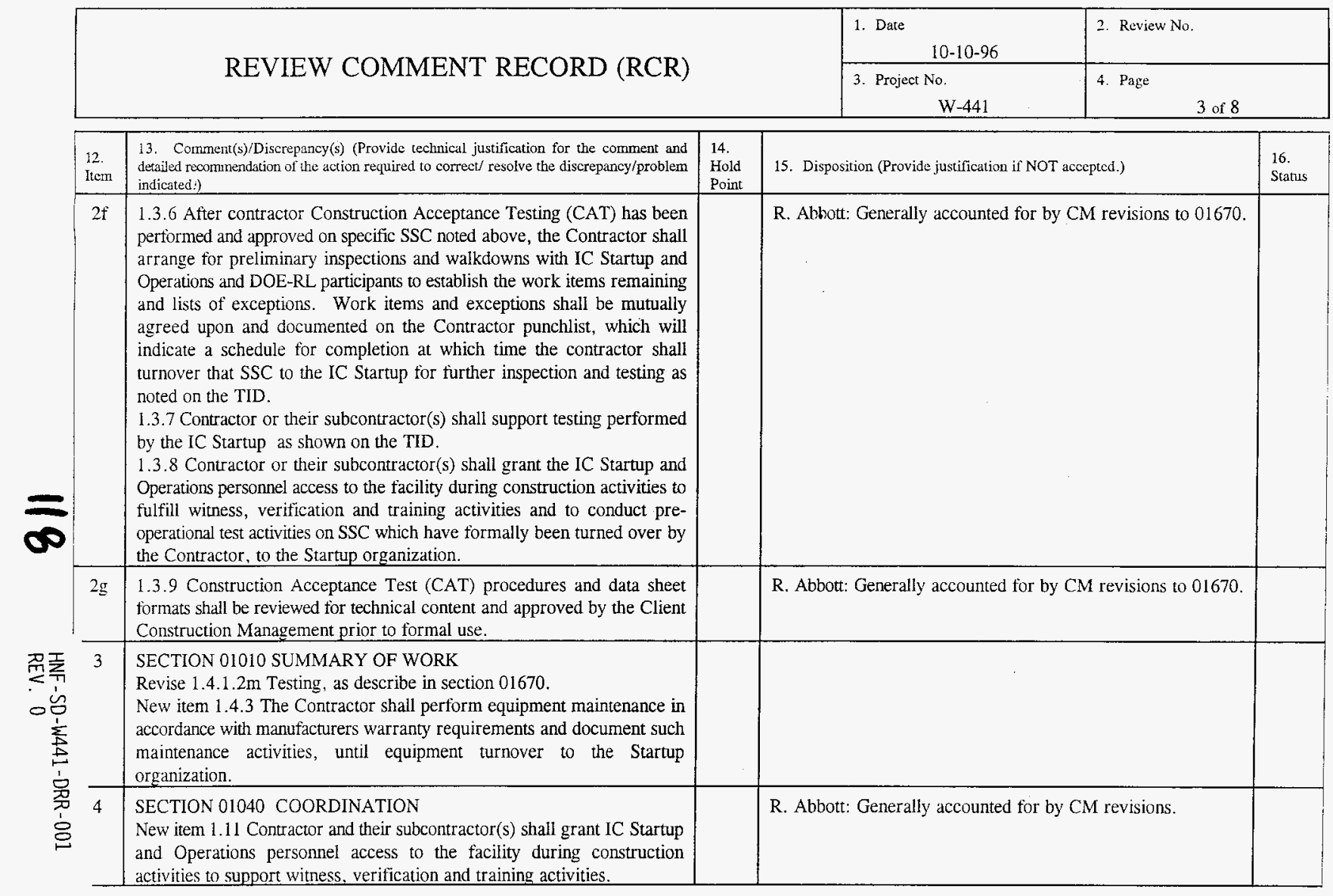




\begin{tabular}{|l|l|l|}
\hline \multirow{2}{*}{ REVIEW COMMENT RECORD (RCR) } & \begin{tabular}{l} 
1. Date Review No. \\
\cline { 2 - 3 }
\end{tabular} & $\begin{array}{c}10-10-96 \\
\text { 3. Project No. } \\
\text { W-441 }\end{array}$ \\
\hline
\end{tabular}

\begin{tabular}{|c|c|c|c|c|}
\hline $\begin{array}{l}12 . \\
\text { Item }\end{array}$ & $\begin{array}{l}\text { 13. Comment(s)/Discrepancy(s) (Provide technical justification for the comment and } \\
\text { detailed recommendation of the action required to correct/ resolve the discrepancy/problem } \\
\text { indicated.) }\end{array}$ & $\begin{array}{l}14 . \\
\text { Hold } \\
\text { Point }\end{array}$ & 15. Disposition (Provide justification if NOT accepeed.) & $\begin{array}{l}16 . \\
\text { Status }\end{array}$ \\
\hline 5 & $\begin{array}{l}\text { SECTION } 01200 \text { PROJECT MEETINGS } \\
\text { New item } 1.5 \text { Startup Planning/Coordination Meetings } \\
1.5 .1 \text { Meetings will be held every two weeks until one month prior to the } \\
\text { first scheduled SSC turnover and weekly thereafter. Times and locations } \\
\text { will be determined at the pre-construction conference. } \\
1.5 .2 \text { The meeting purpose is to establish SSC scoping and schedule } \\
\text { strategies, adjust the TID when necessary, establish turnover/turnback } \\
\text { methods and coordinate testing activities and resources". }\end{array}$ & & R. Abbott: Generally accounted for by CM revisions to 01670 . & \\
\hline 6 & $\begin{array}{l}\text { SECTION } 01300 \text { SUBMITALS } \\
\text { New item } 1.7 \text { Equipment Vendor Data and SSC Turnover Package } \\
\text { Requirements } \\
\text { 1.7.1 Vendor supplied equipment Operation and Maintenance (O\&M) } \\
\text { documentation shall be submitted to Client Construction Management a } \\
\text { minimum of ninety (90) days prior to the scheduled equipment turnover to } \\
\text { the Startup organization. } \\
\text { 1.7.2 SSC turnover package requirements, appendix (A) to this section, } \\
\text { entitled "Construction-to-Startup Turnover Package Contents" provides a } \\
\text { listing of expected package contents. }\end{array}$ & & R. Abbott: Generally accounted for by CM revisions to 01670 . & \\
\hline 7 & $\begin{array}{l}\text { SECTION } 01300 \text { APPENDIX (A) } \\
\text { CONSTRUCTION-TO-STARTUP TURNOVER PACKAGE } \\
\text { CONTENTS } \\
\text { Items common to every package: } \\
\text { Cover sheet with package/system number and construction release } \\
\text { signatures } \\
\text { Index/Table of Contents } \\
\text { Outstanding work/equipment deficiency list } \\
\text { System/Component identity (listing and/or marked dwgs. showing } \\
\text { exactly what is being turned over to Startup) }\end{array}$ & & $\begin{array}{l}\text { R. Abbott: Can be administratively handled. JJI: Will be added } \\
\text { to CM Action List for verification. }\end{array}$ & \\
\hline
\end{tabular}




\begin{tabular}{|l|l|l|}
\hline \multirow{2}{*}{ REVIEW COMMENT RECORD (RCR) } & 1. Date & 2. Revicw No. \\
\cline { 2 - 4 } & 3. Project No. & 4. Page \\
\hline
\end{tabular}

\begin{tabular}{|c|c|c|c|c|}
\hline $\begin{array}{l}12 . \\
\text { Item }\end{array}$ & $\begin{array}{l}\text { 13. Comment(s)/Discrepancy(s) (Provide technical justification for the comment and } \\
\text { detailed recommendation of the action required to correct/ resolve the discrepancy/problem } \\
\text { indicated:) }\end{array}$ & $\begin{array}{l}14 . \\
\text { Hold } \\
\text { Point }\end{array}$ & 15. Disposition (Provide justification if NOT accepled.) & $\begin{array}{l}16 . \\
\text { Status }\end{array}$ \\
\hline 8 & 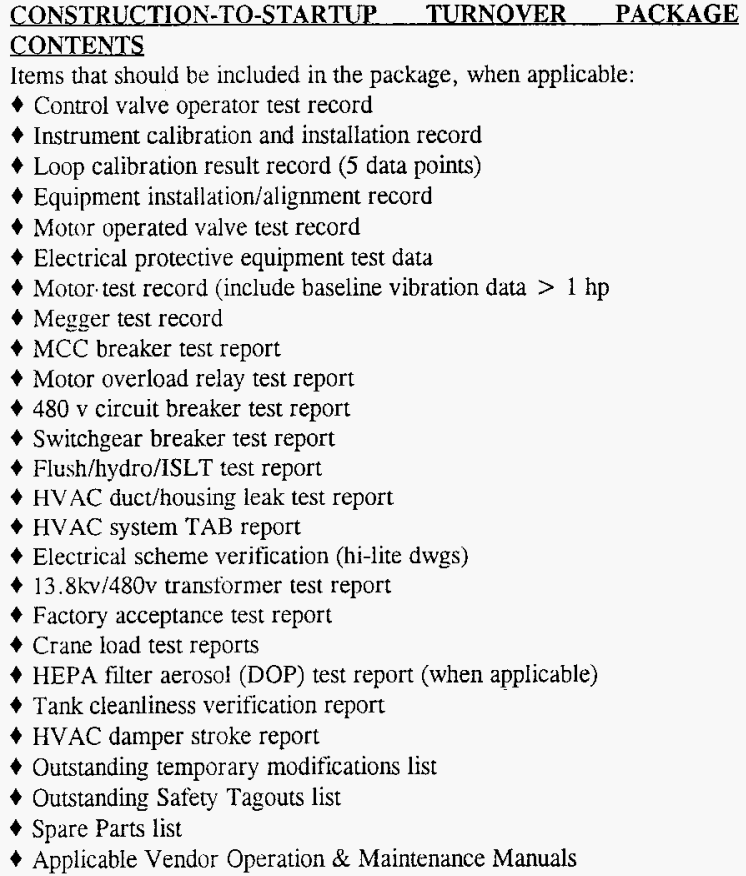 & & JJI: Will be added to CM Action List for verification. & \\
\hline
\end{tabular}




\begin{tabular}{|l|l|l|}
\hline \multirow{2}{*}{ REVIEW COMMENT RECORD (RCR) } & 1. Dale & $10-10-96$ \\
\cline { 2 - 3 } & $\begin{array}{c}\text { 3. Project No. } \\
\text { W-441 }\end{array}$ & 4. Page \\
\hline
\end{tabular}

\begin{tabular}{|c|c|c|c|c|}
\hline $\begin{array}{l}12 . \\
\text { Item }\end{array}$ & $\begin{array}{l}\text { 13. Comment(s)/Discrepancy(s) (Provide technical justification for the comment and } \\
\text { detailed recommendation of the action required to correct/resolve the discrepancy/problem } \\
\text { indicuted.) }\end{array}$ & $\begin{array}{l}14 . \\
\text { Hold } \\
\text { Point }\end{array}$ & 15. Disposition (Provide justification if NOT accepted.) & $\begin{array}{l}\mathbf{1} 6 . \\
\text { Status }\end{array}$ \\
\hline 9 & $\begin{array}{l}\text { APPENDIX (A): } \\
\text { Startup personnel will provide documentation (lists, marked-up drawings, } \\
\text { etc.) identifying specific plant system components that would be expected } \\
\text { in a given turnover package. There should be at least one turnover package } \\
\text { for each plant system. If a system is large and can be divided into } \\
\text { subsystems, partial system turnover packages that comprise a testable } \\
\text { entity, as determined by Startup, are acceptable. } \\
\text { Systems should be turned over trom Construction to Startup in accordance } \\
\text { with the startup schedule, or earlier if available. } \\
\text { Once a specific turnover package has been accepted by Startup, no work } \\
\text { by construction can be initiated on that system without a system/component } \\
\text { turnback authorization approved by the system Startup Engineer or the } \\
\text { Startup Manager. }\end{array}$ & & R. Abbott: CM will co-ordinate with the startup group. & \\
\hline 10 & $\begin{array}{l}\text { SECTION 01315 PROJECT SCHEDULES AND PROGRESS REPORTS } \\
\text { Revise 3.1.1.7 As a minimum .....construction activities, progress } \\
\text { milestones, and projected systems turnover-to-Startup dates. } \\
\text { Add 3.1.1.7 (Z) instrumentation and calibration }\end{array}$ & & R. Abbott: CM will co-ordinate with the startup group. & \\
\hline 11 & $\begin{array}{l}\text { SECTION 01720 PROJECT RECORD DOCUMENTS } \\
\text { Delete 3.3.13 Contractor does not perform "operational testing". } \\
\text { Delete 3.3.14 Contractor does not perform "acceptance test" } \\
\text { Add new item; Construction Contractor submit one (!) complete set of } \\
\text { Turnover Package documentation as described in Section } 01300 \\
\text { "Submittals". }\end{array}$ & & R. Abbott: Generally accounted for by $\mathrm{CM}$ revisions. & \\
\hline
\end{tabular}




\begin{tabular}{|l|l|l|}
\hline \multirow{2}{*}{ REVIEW COMMENT RECORD (RCR) } & 1. Date & 2. Revicw No. \\
\cline { 2 - 3 } & 3. Project No- & W- $10-96$ \\
\hline
\end{tabular}

\begin{tabular}{|c|c|c|c|c|}
\hline $\begin{array}{l}12 . \\
\text { Item }\end{array}$ & $\begin{array}{l}\text { 13. Comment(s)/Discrepancy(s) (Provide technical justification for the comment and } \\
\text { detailed recommendation of the action required to correct/ resolve the discrepancy/problem } \\
\text { indicated!) }\end{array}$ & $\begin{array}{l}14 . \\
\text { Hold } \\
\text { Point }\end{array}$ & 15. Disposition (Provide justification if NOT accepted.) & $\begin{array}{l}16 . \\
\text { Status }\end{array}$ \\
\hline 12 & $\begin{array}{l}\text { SECTION } 15010 \text { GENERAL MECHANICAL } \\
\text { Revise 1.11.18 Ten (10) copies to be provided. } \\
\text { Add } 1.11 .19 \text { The O \& M manuals shall be delivered to the Client } \\
\text { Construction. Manager a minimum of five (5) months prior to SSC } \\
\text { turnover to the Startup organization. }\end{array}$ & & Agreed. & \\
\hline 13 & $\begin{array}{l}\text { SECTION } 15190 \text { MECHANICAL IDENTIFICATION } \\
\text { Revise 1.2.1.1 Suggest that valve ID tags not be stamped metal tags } \\
\text { hanging from chain. They are hard to read. DOE Conduct of Operations } \\
\text { recommends tagging standards which utilize the plastic engraved tags } \\
\text { discussed elsewhere in this specification. Such tag design can also be used } \\
\text { on valves by drilling small holes in the tags and strapping them to valve } \\
\text { inlet pipe using tie-wraps. }\end{array}$ & & Agreed. & \\
\hline 14 & $\begin{array}{l}\text { SECTION } 15480 \text { PROCESS PIPING } \\
\text { Add 1.2.1.2 Add a piping system internal cleanliness standard such as } \\
\text { ANSI N } 45.2 .1 \text { to specify the degree of cleanliness required. Classes A, } \\
\text { B, C, D, very clean to not so clean based on particulate size, shape, and } \\
\text { quantity. }\end{array}$ & & $\begin{array}{l}\text { Cleanliness is "spelled out" in this section. "ANSI N45.2.1" } \\
\text { was not found on ANSI Internet search. }\end{array}$ & \\
\hline 15 & $\begin{array}{l}\text { SECTION } 15487 \text { COMPRESSED AIR PIPING } \\
\text { Comment } 3.5 .1 \text { The test pressure of } 150 \text { psig is less than system operating } \\
\text { pressure of } 175 \text { psig. A standard should be utilized for structural integrity } \\
\text { evaluation and test pressure should be at least } 1.25 \text { times operating } \\
\text { pressure. If this is a leak test, so state. }\end{array}$ & & Line pressure is regulated at 100 psi. Added "LEAK" to 3.5 . & \\
\hline 16 & $\begin{array}{l}\text { SECTION } 15890 \text { DUCTWORK } \\
\text { Comment } 3.1 .4 \text { Specify where system balance pitot tube test port locations } \\
\text { are documented, or make clear that the Contractor is to determine their } \\
\text { location based upon some standard. Also need DOP test ports locations } \\
\text { established. }\end{array}$ & & $\begin{array}{l}\text { Will revise spec to indicate that location of holes required for } \\
\text { pitot traverses shall be required by the testing and balancing } \\
\text { agency. DOP test ports are provided with the HEPA filter } \\
\text { housings as part of the integral test sections specified with the } \\
\text { housings. }\end{array}$ & \\
\hline
\end{tabular}




\begin{tabular}{|l|l|l|}
\hline \multirow{2}{*}{ REVIEW COMMENT RECORD (RCR) } & 1. Date & 2. Review No. \\
\cline { 2 - 4 } & 3. Project No. \\
W-441 & 4. Page \\
\hline
\end{tabular}

\begin{tabular}{|c|c|c|c|c|}
\hline $\begin{array}{l}12 . \\
\text { Item }\end{array}$ & $\begin{array}{l}\text { 13. Comment(s)/Discrepancy(s) (Provide technical justification for the comment and } \\
\text { detailed recommendation of the action required to correct/ resolve the discrepancy/problem } \\
\text { indicated.) }\end{array}$ & $\begin{array}{l}14 . \\
\text { Hold } \\
\text { Point }\end{array}$ & 15. Disposition (Provide justification if NOT accepted.) & $\begin{array}{l}16 . \\
\text { Status }\end{array}$ \\
\hline 17 & $\begin{array}{l}\text { SECTION } 15990 \text { TESTING, ADJUSTING, AND BALANCING; } \\
\text { Add } 3.2 .3 \text { The Startup organization shall concur with balance procedures } \\
\text { prepared by the contractor. Startup personnel may witness vendor balance } \\
\text { activities and shall review test results. } \\
\text { Add item; The TAB contractor shall simulate filter impedance during } \\
\text { balance. } \\
\text { Question; Who is performing the required DOP tests of HEPA systems. }\end{array}$ & & $\begin{array}{l}\text { Agreed. } \\
\text { Agreed. } \\
\text { In-place DOP testing is not in the installation contractor's nor } \\
\text { the TAB Agency's scope of work. This activity is usually } \\
\text { provided by Operations personnel. }\end{array}$ & \\
\hline 18 & $\begin{array}{l}\text { SECTION } 17000 \text { GENERAL INSTRUMENTATION AND CONTROLS } \\
\text { Add } 1.1 .3 \text { I \& C loop functional testing of control and alarm systems shall } \\
\text { include five (5) point calibration, i.e. input/output determined at } 0,25,50 \text {, } \\
75 \text {, and } 100 \text { percent of scale. }\end{array}$ & & $\begin{array}{l}\text { Not-acepted. Net consisten with eriterid requirements from } \\
\text { design authority. JJI: Item added to CM Action List. }\end{array}$ & \\
\hline 19 & $\begin{array}{l}\text { SECTION } 17900 \text { TESTING } \\
\text { Comment; Suggest this section be deleted. ATP's are prepared by the } \\
\text { client or subcontracted to a design authority. } \\
\text { The requirements for correct I \& C systems operability should be with the } \\
\text { overall contractor, even if he subcontracts installation and testing. } \\
\text { Therefore, the loop functional criteria and overall testing criteria for I \& } \\
\text { C equipment should remain in this specification. }\end{array}$ & & $\begin{array}{l}\text { Aot aceepted. See } 18 \text { above. JJI: Item added to CM Action } \\
\text { List. }\end{array}$ & \\
\hline
\end{tabular}




\begin{tabular}{|c|c|c|}
\hline & $\begin{array}{l}\text { 1. Date } \\
08 / 27 / 96\end{array}$ & $\begin{array}{l}\text { 2. Review No. } \\
1\end{array}$ \\
\hline 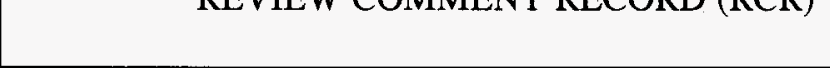 & $\begin{array}{r}\text { 3. Project No. } \\
\text { ? }\end{array}$ & 4. Page \\
\hline
\end{tabular}

\begin{tabular}{|l|l|l|l|l|}
\hline 5. Document Number(s)/Title(s) & $\begin{array}{l}\text { 6. Program/Project/ } \\
\text { Building Number } \\
\text { Spent Nuclear Fuels / } \\
\text { Cold Vacuum Drying } \\
\text { Facility }\end{array}$ & 7. Reviewer & Dean W. Medford & $\begin{array}{l}\text { 9. Location/Phone } \\
\text { K Banization/Group Cognizant } \\
\text { Engineering }\end{array}$ \\
\hline
\end{tabular}

17. Comment Submittal Approval:

Organization Manager (Optional)
10. Agreement with indicated comment disposition(s)

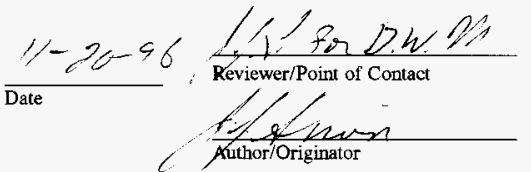

\section{CLOSED}

$$
\frac{11-20-96}{\text { Date }}
$$
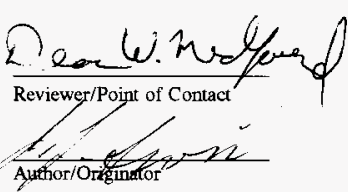

12. 13. Comment(s)/Discrepancy(s) (Provide technical justification for the comment and detailed recommendation of the action required to correct/ resolve the discrepancy/problem indicated.)

H-1-82243 sheets 1 \& 2 indicate HLAN/Telephone outlet boxes to be installed in the process bays, transfer corridor, change rooms, and other process areas of the main CVD structure. There are no HLAN or outside telephone line needed in the process areas, so the installation of the HLAN/Telephone outlet boxes should be restricted to the ones shown for the single story administrative portion of the building. Some type of two way intercom system will be needed with a central station in the control room and remote push to talk speaker phones in the process areas.

\begin{tabular}{|l|l|l|}
\hline $\begin{array}{l}\text { 14. } \\
\text { Point }\end{array}$ & 15. Disposition (Provide justification if NOT accepted.) & $\begin{array}{l}16 . \\
\text { Status }\end{array}$ \\
\hline $\begin{array}{l}\text { The extent of the HLAN/telephone work to be performed by this } \\
\text { locations shown on the plans. Please be advised that actual } \\
\text { communications system design and installation, including HLAN } \\
\text { drops, will be by Lockheed Martin, not the Contractor. }\end{array}$ & Corer \\
\hline
\end{tabular}




\begin{tabular}{|l|l|l|l|}
\hline \multirow{2}{*}{ REVIEW COMMENT RECORD (RCR) } & 1. Date Review No. & $08 / 27 / 96$ & \multicolumn{1}{|c|}{1} \\
\cline { 2 - 3 } & 3. Project No. & 4. Page \\
\hline
\end{tabular}

\begin{tabular}{l|l|l|l|l}
\hline 5. Document Number(s)/Title(s) & $\begin{array}{l}\text { 6. Program/Project } \\
\text { Building Number } \\
\text { CVent Nuclear Fuels / } \\
\text { Cold Vacuum Drying } \\
\text { Facility }\end{array}$ & 7. Reviewer & Dean W. Medford & $\begin{array}{l}\text { 9. Location/Phone } \\
\text { K Basization/Group Cognizant } \\
\text { Engineering }\end{array}$ \\
\hline
\end{tabular}

17. Comment Submittal Approval:

10. Agreement with indicated comment disposition(s)

11. CLOSED

Organization Manager (Optional)

$\overline{\text { Date }}$ Reviewer/Point of Contact

Date

Reviewer/Point of Contact

$\overline{\text { Author/Originator }} \quad \overline{\text { Author/Originator }}$

\begin{tabular}{|l|l|l|l}
\hline 13 & Comment(s)/Discrepancy(s) (Provide technical justification for the comment and
\end{tabular} 12.
Item detailed reconmmendation of the action required to correct/ resolve the discrepancy/problem indicated.)

\begin{tabular}{|c|c|c|}
\hline $\begin{array}{l}14 . \\
\text { Hold } \\
\text { Point }\end{array}$ & 15. Disposition (Provide justification if NOT accepted.) & $\begin{array}{l}16 . \\
\text { Status }\end{array}$ \\
\hline & $\begin{array}{l}\text { The extent of the HLAN/telephone work to be performed by this } \\
\text { Contractor is to install conduit drops and (4) square outlet boxes at the } \\
\text { locations shown on the plans. Please be advised that actual } \\
\text { communications system design and installation, including HLAN drops, } \\
\text { will be by Lockheed Martin, not the Contractor. }\end{array}$ & \\
\hline
\end{tabular}




\section{REVIEW COMMENT RECORD (RCR)}

\begin{tabular}{|c|l|}
\hline $\begin{array}{l}\text { 1. Date } 10 / 7 / 96 \\
\text { 3. Project No. } \\
\text { W-441-Cl }\end{array}$ & \multicolumn{1}{|l|}{ 2. Review No. } \\
\hline
\end{tabular}

\section{Document Number(s)/Title(s) \\ W-441-C1/COLD VACUUM DRYING FACILITY, CONSTRUCTION SPECIFICATION, 90\% REVIEW}

17. Comment Submittal Approval:

\begin{tabular}{|l|l}
$\begin{array}{l}\text { 6. Program/Project/ } \\
\text { Building Number } \\
\text { W-441-C1 }\end{array}$ & 7. Reviewer \\
C. F. MYOTT
\end{tabular}

10. Agreement with indicated comment disposition(s)

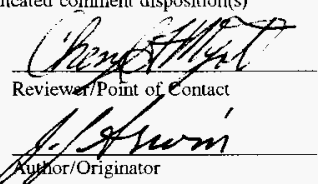

8. Organization/Group

SNFP/COG ENG
9. Location/Phone

$1718 \mathrm{~K} / 23 / 100 \mathrm{~K} 376$ 0879

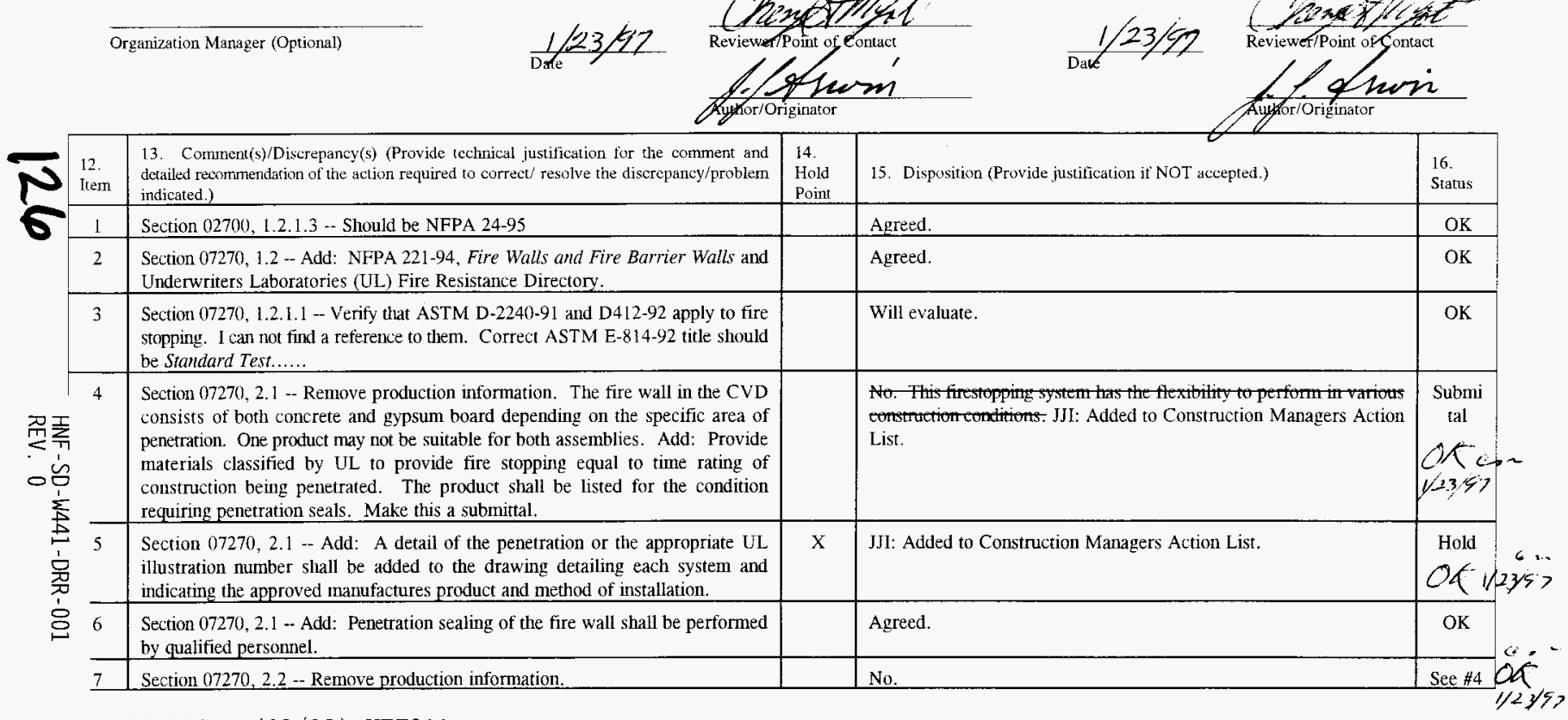

11. CLOSED
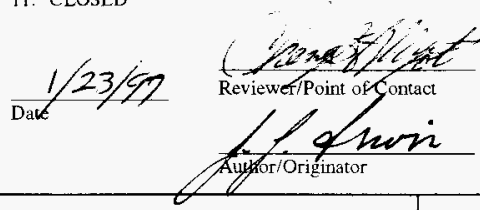


\begin{tabular}{|c|c|c|c|c|c|c|}
\hline & \multirow{2}{*}{\multicolumn{2}{|c|}{ REVIEW COMMENT RECORD (RCR) }} & & 1. Date & \multicolumn{2}{|l|}{$\begin{array}{r}\text { 2. Review No. } \\
\text { N/A }\end{array}$} \\
\hline & & & & $\begin{array}{l}\text { 3. Project No. } \\
\text { W-441-C1 }\end{array}$ & \multicolumn{2}{|l|}{$\begin{array}{l}\text { 4. Page } \\
2 \text { of } 3 \\
\end{array}$} \\
\hline 12 & $\begin{array}{l}\text { 13. Comment(s)/Discrepancy(s) (Provide technical justification for the cornment and } \\
\text { derailed recommendation of the action required to correct/ resolve the discrepancy/problem } \\
\text { indicated.) }\end{array}$ & $\begin{array}{l}14 . \\
\text { Hold } \\
\text { Point }\end{array}$ & \multicolumn{3}{|c|}{ 15. Disposition (Provide justification if NOT accepted.) } & $\begin{array}{l}16 . \\
\text { Status }\end{array}$ \\
\hline rata & $\begin{array}{l}\text { Section } 08100,1.2 .1 .2 \text { - Should be NFPA } 80-95 \text { and add NFPA 252, Standard } \\
\text { Methods of Fire Tests of Door Assemblies }\end{array}$ & & \multicolumn{3}{|l|}{ Agreed. } & $\mathrm{OK}$ \\
\hline sina & $\begin{array}{l}\text { Section } 08100--\mathrm{I} m \text { not sure that this is the correct section but the glazing in the } \\
\text { door needs to be addressed. The wire glass is required to meet ANSI Z97.1, } \\
\text { Safety Performance Specifications and Methods of Test for Safety Glazing } \\
\text { Materials Used in Buildings }\end{array}$ & $\mathrm{x}$ & \multicolumn{3}{|c|}{ Will address in section. } & $\mathrm{OK}$ \\
\hline 1 & $\begin{array}{l}\text { Section } 08100 \text {, PART } 2 \text {-- Add } 2.4 \text { FIRE DOOR ASSEMBLY, This section shall } \\
\text { discuss that the door and frame shall be listed as an assembly. The hardware used } \\
\text { shall be fire listed. Labels and stamps on the marerial shall be visible after } \\
\text { installation. }\end{array}$ & $\mathrm{X}$ & \multicolumn{3}{|l|}{ Agreed. } & OK \\
\hline 1 & $\begin{array}{l}\text { Section } 10520,3.1 .1-\text { Replace "applicable regulation of governing authorities" } \\
\text { with "NFPA } 10 \text { " }\end{array}$ & & \multicolumn{3}{|c|}{ Not accepted. Authority having jurisdiction can defer for NFPA 10.} & OK \\
\hline 1 & $\begin{array}{l}\text { Section } 15300,1.1-\text { Add DOE } 5480.7 \mathrm{~A}, \text { Fire Protection and DOE } 6430.1 \mathrm{~A} \text {, } \\
\text { General Design Criteria }\end{array}$ & & \multicolumn{3}{|c|}{$\begin{array}{l}\text { Not changed. These are design criteria, not construction standards. } \\
\text { Applicable requirements are inherent in the design. }\end{array}$} & OK \\
\hline & Section 15300, 1.2.2.3 -- Typo: Contractors'S should be Contractors' & & \multicolumn{3}{|c|}{ Corrected to full title of form from NFPA 13.} & $\mathrm{OK}$ \\
\hline & Section $15300,2.3 .6$-- Typo by 2-1/2-inch hose thread appears twice. & & \multicolumn{3}{|c|}{ Correct as is the specified connection is a two-way inlet type. } & $\mathrm{OK}$ \\
\hline & $\begin{array}{l}\text { Section } 15300,3.1 .6 .3 \text {, Paragraph b. -- Change the 1-hour to 2-hours. The wall } \\
\text { is a } 2 \text {-hour wall and shall be sealed accordingly. }\end{array}$ & $\mathrm{X}$ & \multicolumn{3}{|c|}{ Corrected to 2-hour, affected paragraph 2.2.5.2 also. } & OK \\
\hline & Section $15300,3.2 .3 .3$-- Make this a witness point. & & \multicolumn{3}{|c|}{ Added to Section 01400} & $\mathrm{OK}$ \\
\hline 1 & $\begin{array}{l}\text { Section } 15978-15981-\text { State that any heat and/or smoke detectors that will } \\
\text { interface with the fire alarm system be list for a System } 3 \text {. }\end{array}$ & & \multicolumn{3}{|c|}{$\begin{array}{l}\text { Equipment and Instrument specifications are not provided in a } \\
\text { sequence of operation. Refer to the appropriate specification section } \\
\text { for smoke detectors. }\end{array}$} & OK \\
\hline & Section 16720 - General throughout. Change FACP to FCP (Hanford Standard). & & \multicolumn{3}{|c|}{ Agreed. Will incorporate as suggested. } & OK \\
\hline 1 & Section $16720,2.1$-- Add strobe requirements. & & \multicolumn{3}{|c|}{ Agreed. Will incorporate as suggested. } & OK \\
\hline & $\begin{array}{l}\text { Section } 16720,3.1 .3 .2 \text {-- I have verified that we do not have calibrated crimpers } \\
\text { at } K \text { Basins because we have no safety class electrical/electronic systems. Remove } \\
\text { the statement and if this is to be a requirement have the installer supply the } \\
\text { crimpers. }\end{array}$ & & \multicolumn{3}{|c|}{ Agreed. Will incorporate as suggested. } & OK \\
\hline
\end{tabular}




\begin{tabular}{|l|l|l|}
\hline \multirow{2}{*}{ REVIEW COMMENT RECORD (RCR) } & $\begin{array}{l}\text { 1. Date } \\
10 / 7 / 96\end{array}$ & $\begin{array}{r}\text { 2. Review No. } \\
\text { N/A }\end{array}$ \\
\cline { 2 - 3 } & $\begin{array}{l}\text { 3. Project No. } \\
\text { W-441-C1 }\end{array}$ & $\begin{array}{l}\text { 4. Page } \\
3 \text { of } 3\end{array}$ \\
\hline
\end{tabular}

\begin{tabular}{|c|c|c|c|c|}
\hline $\begin{array}{l}12 . \\
\text { Item }\end{array}$ & $\begin{array}{l}\text { 13. Comment(s)/Discrepancy(s) (Provide technical justification for the comment and } \\
\text { detailed recommendation of the action required to correct/ resolve the discrepancy/problem } \\
\text { indicated.) }\end{array}$ & $\begin{array}{l}14 . \\
\text { Hold } \\
\text { Point }\end{array}$ & 15. Disposition (Provide justification if NOT accepted.) & $\begin{array}{l}16 . \\
\text { Status }\end{array}$ \\
\hline 21 & $\begin{array}{l}\text { Section } 16720,3.1 .3 .3 \text {-- State that power limited cable shall be labeled and that } \\
\text { nompower-limited and power-limited be run in separate conduit. }\end{array}$ & & Agreed. Will incorporate as suggested. & $\mathrm{OK}$ \\
\hline 22 & $\begin{array}{l}\text { Section } 16720,3.1 .3 .7 \text {-- Add strobe wire colors of light and dark purple to the } \\
\text { table. }\end{array}$ & & $\begin{array}{l}\text { Agreed, will incorporate as suggested. Please identify a cable supplier } \\
\text { previously used at Hanford to provide these colors as standard. The } \\
\text { cable used as a design basis does not offer these colors. }\end{array}$ & OK \\
\hline 23 & $\begin{array}{l}\text { Section } 16720,3.1 .10 \text {-- Add that the completed ATP be provided to facility } \\
\text { operations. }\end{array}$ & & Agreed. Will incorporate as suggested. & OK \\
\hline
\end{tabular}




\section{REVIEW COMMENT RECORD (RCR)}

\begin{tabular}{|c|l|}
\hline $\begin{array}{c}\text { 1. Date } \\
10 / 17 / 96\end{array}$ & $\begin{array}{l}\text { 2. Review No. } \\
\text { N/A }\end{array}$ \\
\hline $\begin{array}{c}\text { 3. Project No. } \\
\text { W-441 }\end{array}$ & 4. Page $\quad 1$ of 2 \\
\hline
\end{tabular}

\begin{tabular}{|l|l|l|l|l|}
\hline 5. Document Number(s)/Title(s) & $\begin{array}{l}\text { 6. Program/Project/ } \\
\text { Building Number }\end{array}$ & 7. Reviewer & 8. Organization/Group & 9. Location/Phone \\
\hline $\begin{array}{l}\text { MW6-SWV-310416, TASK 16/COLD } \\
\text { VACUUM DRYING FACILITY }\end{array}$ & SNFP/W-441/147 K & C. F. MYOTT & SNFP/COG ENG & $\begin{array}{l}\text { 1718K/23/100K } \\
\mathbf{3 7 6 - 0 8 7 9}\end{array}$ \\
\hline
\end{tabular}

17. Comment Submittal Approval:

Organization Manager (Optional)
10. Agreement with indicated comment disposition(s)

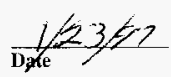

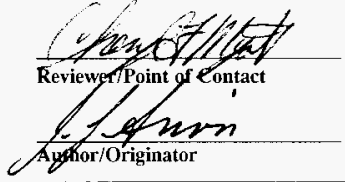

11. CLOSED

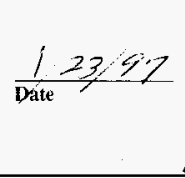

is

12. 13. Comment(s)/Discrepancy(s) (Provide technical justification for the comment 12. and detailed recommendation of the action required to correct/ resolve the discrepancy/problem indicated.)

1 H-1-82092 -- Numbering of FP components was accepted in $60 \%$ RCR. Please change FH1 to FH22 and FH2 to FH23. Add: FPPIV-147K to the PIV. Add: SW SERVICE WATER to the legend.

2 H-1-82094 -- Add: FP-V -603 to the valve at flag $\# 2$. This valve is to be electronically supervised.

3 H-1-82094, F4 -- Change FW to SW. It is the service water system until it reaches valve number FP-V-603 (flag \#2) and then it is the fire water system.

4 H-1-82112 -- Indicate that door 32 shall be a listed door/frame 11/2-hour fire rated assembly.

5 H-1-82113 -- Change drawing number on detail 12 from H-1-821102 to $\mathrm{H}-1-82102$.

6 H-1-92192 through 95 -- Add the appropriate drawing number to Note \#1.

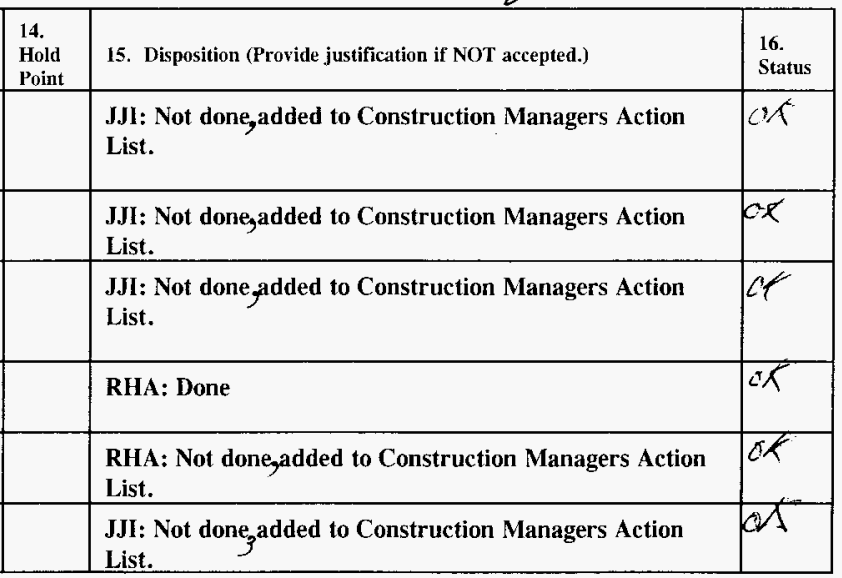




\section{REVIEW COMMENT RECORD (RCR)}

\begin{tabular}{|c|c|}
\hline \begin{tabular}{|l|} 
1. Date \\
$10 / 17 / 96$
\end{tabular} & \multicolumn{2}{|c|}{ N/A } \\
\hline $\begin{array}{c}\text { 3. Project No. } \\
\text { W-441 }\end{array}$ & 4. Page \\
\hline
\end{tabular}

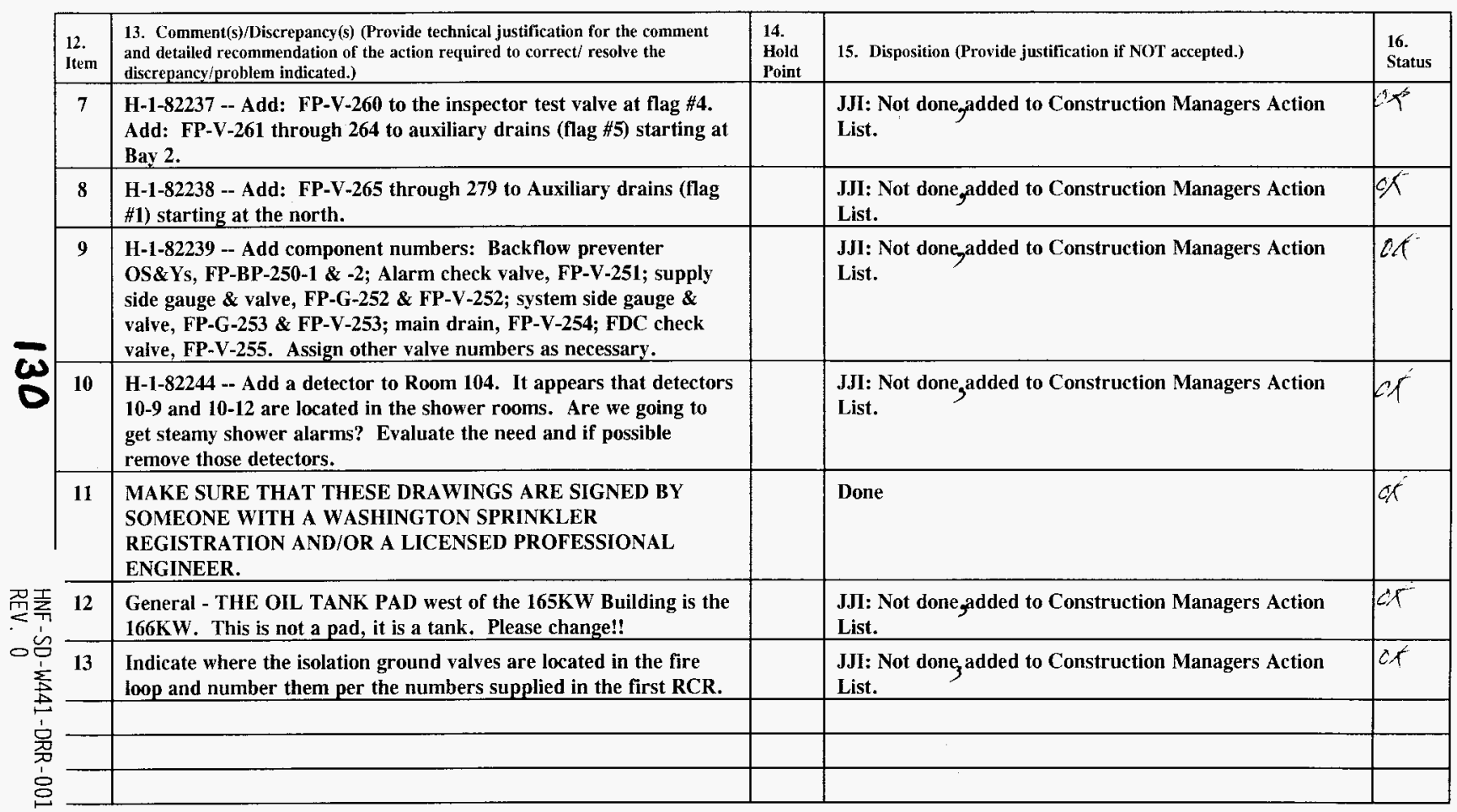




\section{REVIEW COMMENT RECORD (RCR)}

\begin{tabular}{|l|l|}
\hline \multicolumn{1}{|l|}{$10 / 06 / 96$} & 2. Review No. \\
\hline 3. Project No. & 4. Page $\quad 1$ of 3 \\
\hline
\end{tabular}

\begin{tabular}{|l|l|l|l|l|}
\hline $\begin{array}{l}\text { 5. Document Number(s)/Title(s) } \\
\text { 90\% CVD REVIEW }\end{array}$ & $\begin{array}{l}\text { 6. Program/Project/ } \\
\text { Building Number } \\
\text { CVD }\end{array}$ & $\begin{array}{l}\text { 7. Reviewer } \\
\text { EM MYOTT }\end{array}$ & $\begin{array}{l}\text { 8. Organization/Group } \\
\text { K BASINS } \\
\text { ENGINEERING }\end{array}$ \\
\hline
\end{tabular}

17. Comment Submittal Approval:

Organization Manager (Optional)
10. Agreement with indicated_comment disposition(s)

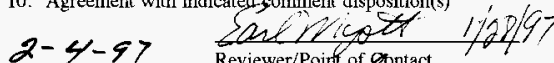

11. CLOSED

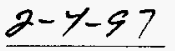

Date

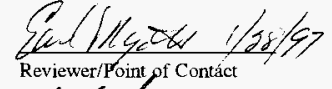

,

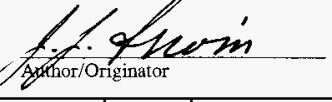

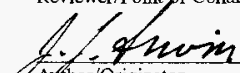

fithor originator

\begin{tabular}{|c|c|c|c|c|}
\hline $\begin{array}{l}12 . \\
\text { Item }\end{array}$ & $\begin{array}{l}\text { 13. Comment(s)/Discrepancy(s) (Provide technical justification for the comment and } \\
\text { detailed recommendation of the action required to correct/ resolve the } \\
\text { discrepancy/problem indicated.) }\end{array}$ & $\begin{array}{l}14 . \\
\text { Hold } \\
\text { Point }\end{array}$ & 15. Disposition (Provide justification if NOT accepted.) & $\begin{array}{l}16 . \\
\text { Status }\end{array}$ \\
\hline 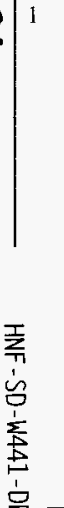 & $\begin{array}{l}\text { ADD REQUIREMENT: } \\
\text { Stationary area radiation monitoring shall be installed in frequently } \\
\text { occupied locations with the potential for unexpected increases in dose } \\
\text { rates and in remote locations where there is need for local indication of } \\
\text { dose rates prior to personnel entering remote locations. These } \\
\text { requirements are found in (Article } 553 \text {, HSRCM-1 "Hanford Site } \\
\text { Radiological Control Manual" \& Section } 835.403 \text { (b), 10CFR Part } \\
835 \text {, "Department of Energy } 10 \text { CFR Part } 835 \text { Occupational Radiation } \\
\text { Protection") Also see DOE order } 6430.1 \text { A, Section } 1300-6.5 .4 \text {. } \\
\text { As an example I would expect an area radiation monitor to be required } \\
\text { in work area around top of cask, at work area around skid, and } \\
\text { possible at waste tank area . If found not necessary, document a } \\
\text { justification as to why not needed (i.e. dose studies, non-credible } \\
\text { exposures, etc.) }\end{array}$ & & $\begin{array}{l}\text { Areatadiation monitoring is a thange in scope from previous } \\
\text { direction and must be authorized by Jeff Fitip and Kirk } \\
\text { Elfard. Area radiation monitoring equipment can be added } \\
\text { within each process bay without adding conduits that leave } \\
\text { that bay, in other words, no additional or larger wall } \\
\text { penetrations are required as long as the alarms report to the } \\
\text { remote I/O rack within that bay. This is easily added as an } \\
\text { addendum during construction. Also, all radiation equipment } \\
\text { is intended to be GFE. Will add area radiation monitoring } \\
\text { requirements as directed by Merrick based on dose studies, } \\
\text { non-credible exposures, etc. Meier Associatesisawaiting } \\
\text { writtendireetion from Kirk Ellard, Merrick-Engineers. } \\
\text { JJI: Alpha and Beta CAMs will be added to each process bay } \\
\text { and to the Tank room. CAMs are GFE. This item added to } \\
\text { CM Action List. }\end{array}$ & $\mathrm{OK}$ \\
\hline
\end{tabular}




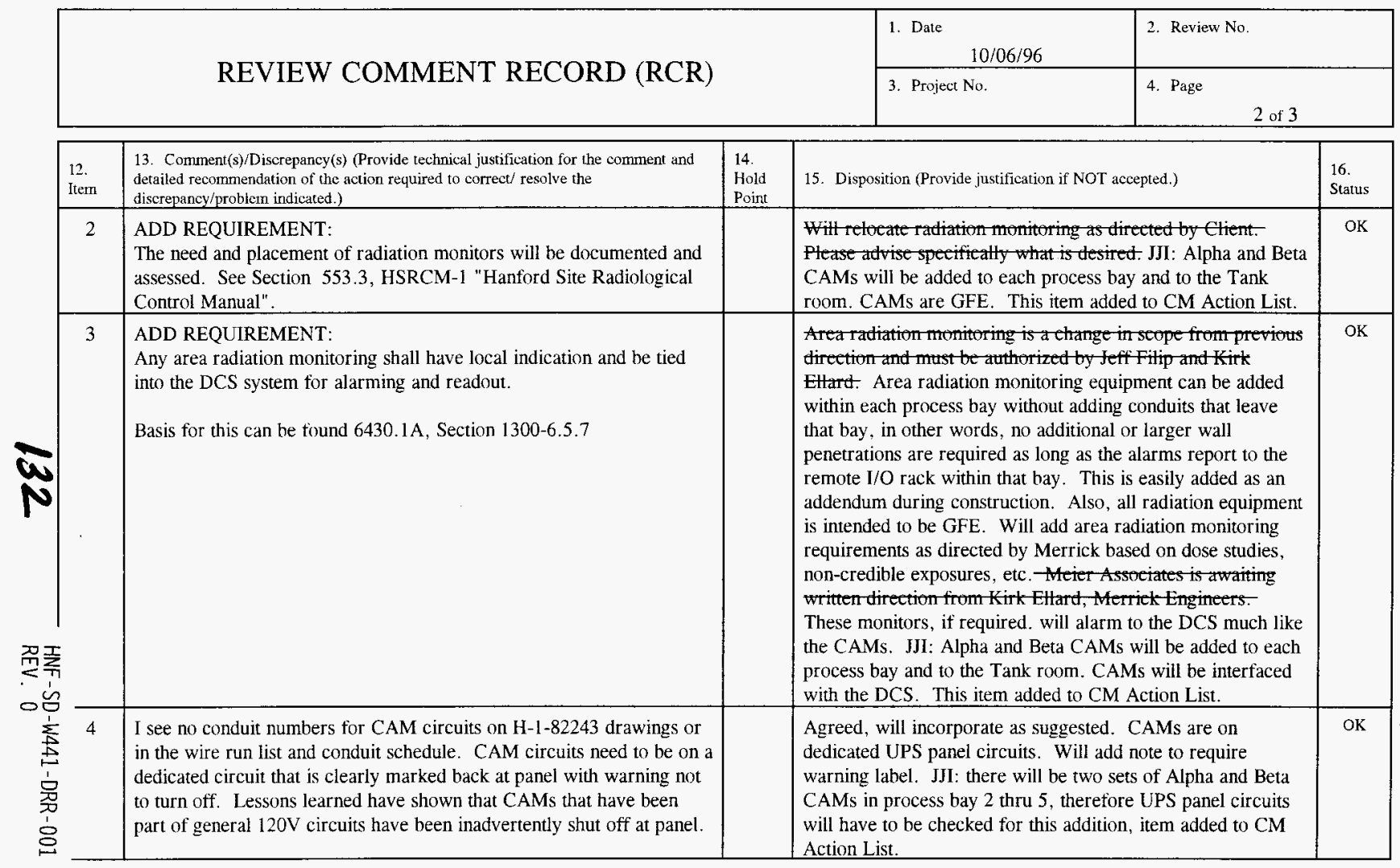




\begin{tabular}{|l|l|l|}
\hline \multirow{2}{*}{ REVIEW COMMENT RECORD (RCR) } & 1. Date Review No. & $10 / 06 / 96$ \\
\cline { 2 - 3 } & 3. Project No. & 4. Page \\
\hline
\end{tabular}

\begin{tabular}{|c|c|c|c|c|}
\hline $\begin{array}{l}12 . \\
\text { ltem }\end{array}$ & $\begin{array}{l}\text { 13. Comment(s)/Discrepancy(s) (Provide technical justification for the comment and } \\
\text { detailed recommendation of the action required to correct/ resolve the } \\
\text { discrepancy/problem indicated.) }\end{array}$ & $\begin{array}{l}14 . \\
\text { Hold } \\
\text { Point }\end{array}$ & 15. Disposition (Provide justification if NOT accepted.) & $\begin{array}{l}16 . \\
\text { Status }\end{array}$ \\
\hline 5 & $\begin{array}{l}\text { Health Physics requires CAMs (Continuous Air Monitor) to be Alpha } \\
\text { \& Beta. Drawing H-1-82243 shows Beta only. }\end{array}$ & & $\begin{array}{l}\text { Alpha radiation monitoring is a change in seope from } \\
\text { previous diretion and must be authorized by Jeff Filip and } \\
\text { Kirk Ellard. Alpha radiation monitoring equipment can be } \\
\text { added within each process bay without adding conduits that } \\
\text { leave that bay, in other words, no additional or larger wall } \\
\text { penetrations are required as long as the alarms report to the } \\
\text { remote I/O rack within that bay. Also, all radiation } \\
\text { equipment is intended to be GFE. This is easily added as an } \\
\text { addendum during construction. Will add area radiation } \\
\text { monitoring requirements as directed by Merrick based on } \\
\text { dose studies, non-credible exposures, etc.-Meier Assoeiates } \\
\text { is awaiting written direetion from Kirk Elfard, Merrick } \\
\text { Engineers. JJI: Alpha and Beta CAMs will be added to each } \\
\text { process bay and to the Tank room. This item added to CM } \\
\text { Action List. }\end{array}$ & OK \\
\hline 6 & $\begin{array}{l}\text { Add section } 17 x x x \text { to Construction Specification Project W-441-Cl } \\
\text { describing radiation protection instrumentation, i.e. airborne (CAMs), } \\
\text { area monitors, and personnel monitors. }\end{array}$ & & $\begin{array}{l}\text { Currently all radiation monitoring equipment is intended to be } \\
\text { specified on the drawings by manufacturer and part number } \\
\text { rather than functionally describing them in the specifications. } \\
\text { Also, all radiation equipment is intended to be GFE. }\end{array}$ & OK \\
\hline
\end{tabular}

备采 Note; It is the responsibility of the Design Authority to provide for Radiation Monitoring as required per 10CFR875, HSRCM-1, and 6430.1a. Documentation as to in need and placement should come from dose analysis that show potential increased dose to the worker in the workplace. The intent here is to document why detector

is needed and if placement location provides adequate coverage of worker area. An example of such documentation is "Point Source Alarm Trigger Value

Calculations for the K-Basin Programmable Radiation Monitoring System", WHC-SD-SNF-RPT-001. This documentation was used to evaluate detector coverage in $F$ the Basins for fuel movement. Another example is WHC-SD-SNF-TA-001, "K-Basins Workplace Air Sampling".

员
总
용 


\begin{tabular}{|l|l|l|}
\hline \multirow{2}{*}{ REVIEW COMMENT RECORD (RCR) } & 1. Date $10 / 06 / 96$ & 2. Review No. \\
\cline { 2 - 3 } & 3. Project No. & 4. Page 1 of 3 \\
\hline
\end{tabular}

\begin{tabular}{|l|l|l|l|l|}
\hline 5. Document Number(s)/Title(s) & $\begin{array}{l}\text { 6. Program/Project/ } \\
\text { Bujlding Number } \\
\text { CVD }\end{array}$ & $\begin{array}{l}\text { 7. Reviewer } \\
\text { EM MYOTT }\end{array}$ & $\begin{array}{l}\text { Organization/Group } \\
\text { K BASINS ENGINEERING }\end{array}$ & \begin{tabular}{l} 
1718K/373-2050 \\
\hline
\end{tabular}
\end{tabular}

\section{Comment Submittal Approval:}

Organization Manager (Optiona1)
10. Agreement with indicated comment disposition(5)

Date

\section{CLOSED}

Date
Reviewer/Point of Contact

\section{Author/originator}

Author/Originator

12. 13. Corment(s)/Discrepancy(s) (Provide technical justification for

Item the comment and detailed recommendation of the action required to correct/ resolve the discrepancy/problem indicated.)

1 ADD REQUIREMENT

Stationary area radiation monitoring shall be installed in frequently occupied locations with the potential for

unexpected increases in dose rates and in remote locations where there is need for local indication of dose rates

prior to personnel entering remote locations. These

recuirements are found in (Article 553. HSRCM-1 "Hanford

Site Radiological Control Manual" \& Section 835.403 (b).

10CFR Part 835, "Department of Energy loCFR Part 835

Dccupational Radiation Protection") Also see DOE order

6430.1A. Section 1300-6.5.4

As an example I would expect an area radiation monitor to

14.

15. Disposition (Provide justification if NOT accepted.)

Area radiation monitoring is a change in scope from previous direction and must be authorized by Jeff

Filip and Kirk Ellard. Area radiation monitoring equipment can be added within each process bay without adding conduits that leave that bay, in other words, no additional or larger wall

penetrations are required as long as the alarms

report to the remote $1 / 0$ rack within that bay.

This is easily added as an addendum during

construction. Also, all radiation equipment is

intended to be GFE. Wilt add area radiation

monitoring requirements as directed by Merrick

based on dose studies, non-credible exposures, etc.

be required in work area around top of cask, at work area

Meier Associates is awaiting written direction from around skid, and possible at waste tank area. If found

끌 not necessary, document a justification as to why not

$\leqslant \frac{1}{1}$ needed (i.e dose studies, non-credible exposures. etc.)

○ٌ

$0 \underset{1}{1}$

Show locations on H-1-82243 drawings

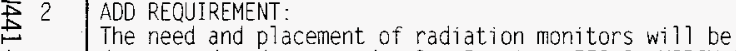

documented and assessed. See Section 553.3. HSRCM-1

弅 Hanford Site Radiological Control Manual"

Kirk Ellard, Merrick Engineers

8

Wi11 relocate radiation monitoring as directed by

client. Please advise specifically what is

desired. 


\begin{tabular}{|l|l|l|}
\hline \multirow{2}{*}{ REVIEW COMMENT RECORD (RCR) } & 1. Date Review No. \\
\cline { 2 - 3 } & 3. Project No. & 4. Page \\
\hline
\end{tabular}

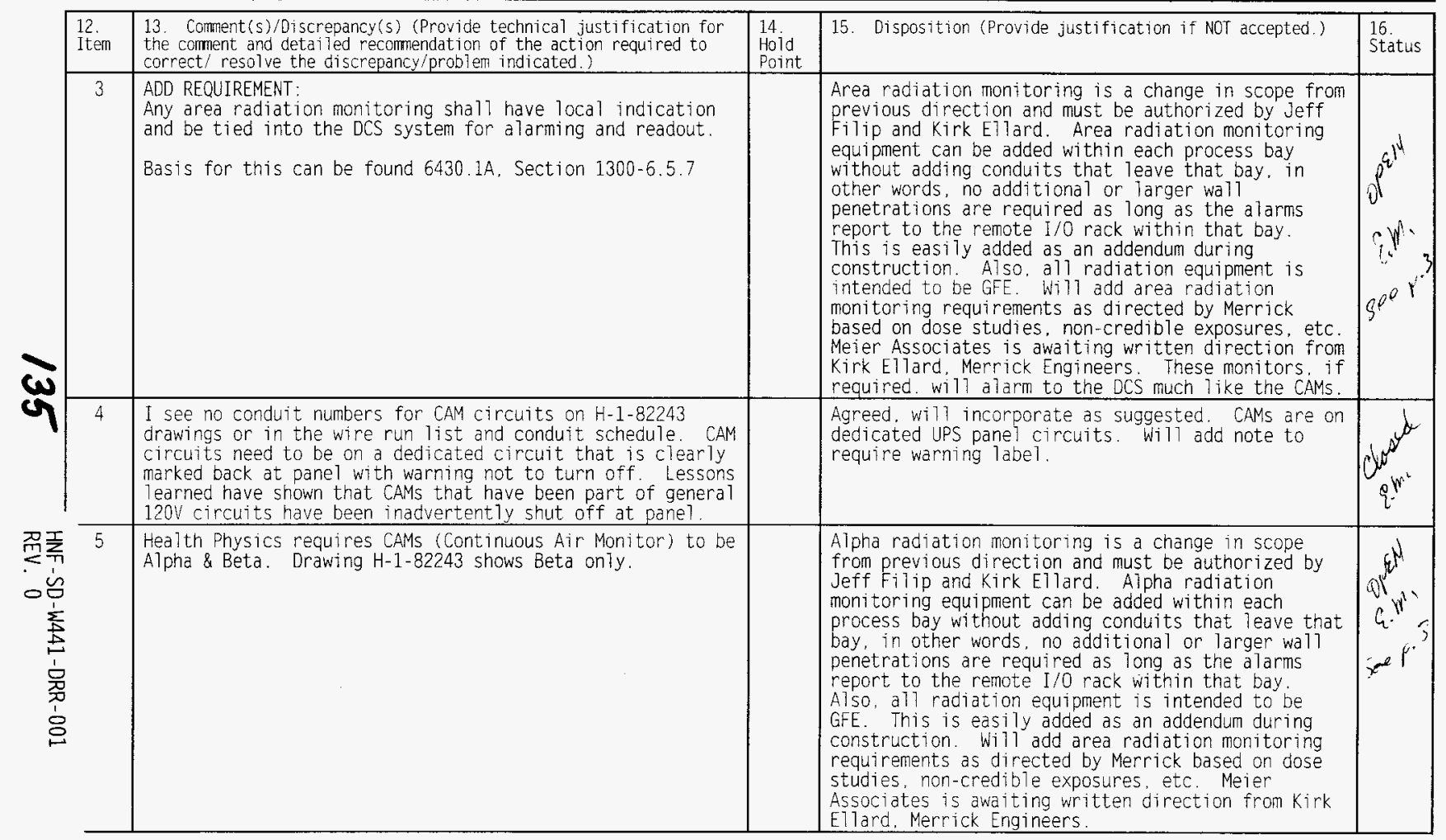




\begin{tabular}{|l|l|l|}
\hline \multirow{2}{*}{ REVIEW COMMENT RECORD (RCR) } & 1. Date $10 / 06 / 96$ & Review No. \\
\cline { 2 - 4 } & 3. Project No. & 4 . Page 3 of 3 \\
\hline
\end{tabular}

\begin{tabular}{|c|c|c|c|c|}
\hline $\begin{array}{l}12 . \\
\text { Item }\end{array}$ & $\begin{array}{l}\text { 13. Comment(s)/Discrepancy(s) (Provide technical justification for } \\
\text { the comment and detailed recommendation of the action required to } \\
\text { correct/ resolve the discrepancy/problem indicated.) }\end{array}$ & $\begin{array}{l}14 \\
\text { Hold } \\
\text { Point } \\
\end{array}$ & 15. Disposition (Provide justification if NOT accepted.) & $\begin{array}{l}16 . \\
\text { Status }\end{array}$ \\
\hline 6 & $\begin{array}{l}\text { Add section } 17 \times \times x \text { to Construction Specification Project } W \text { - } \\
441-C 1 \text { describing radiation protection instrumentation, } \\
\text { i.e. airborne (CAMs), area monitors, and personnel } \\
\text { monitors. }\end{array}$ & & $\begin{array}{l}\text { Currently all radiation monitoring equipment is } \\
\text { intended to be specified on the drawings by } \\
\text { manufacturer and part number rather than } \\
\text { functionally describing them in the specifications. } \\
\text { Also. all radiation equipment is intended to be } \\
\text { GFE. }\end{array}$ & $i_{i}^{n}$ \\
\hline
\end{tabular}

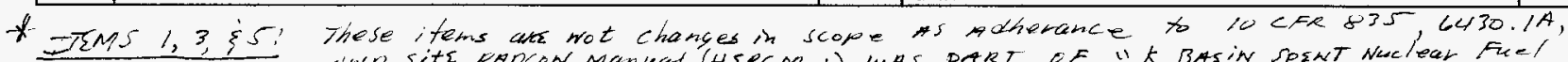

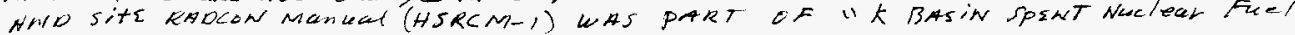

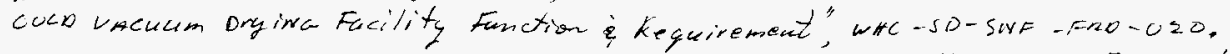

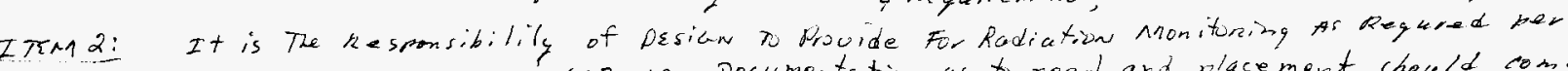
à

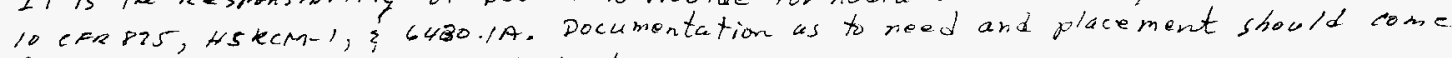
from Dose anclysis that show Potentia/ increasod dese to the workor in the workyloce.

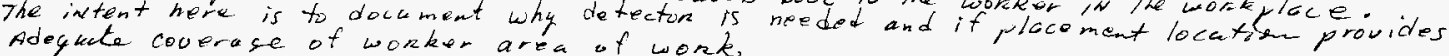
In example of such documentation is Point source flarm trigger Value cakalations

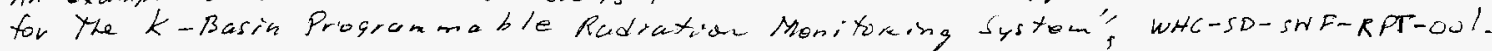

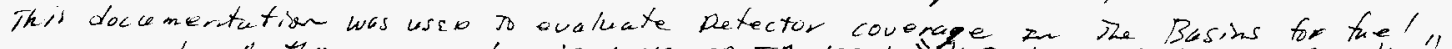

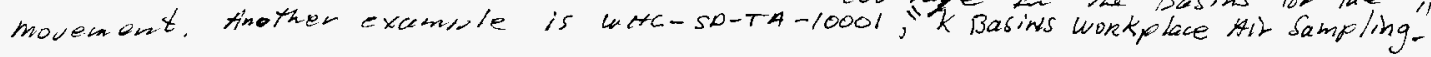

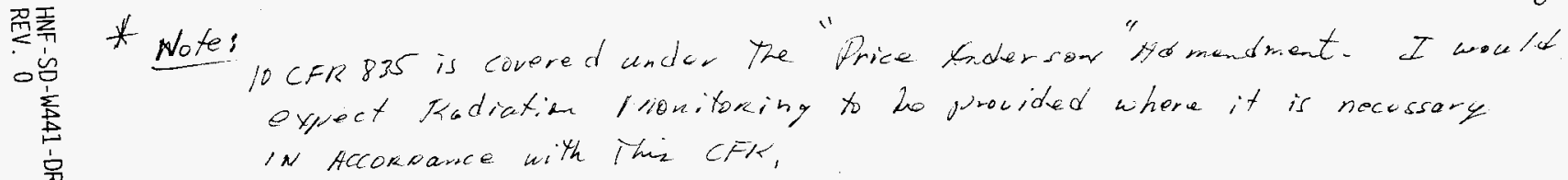




\section{REVIEW COMMENT RECORD (RCR)}

\begin{tabular}{|l|l|}
\hline $\begin{array}{l}\text { 1. Date } \\
10 / 4 / 96\end{array}$ & 2. Review No. \\
\hline $\begin{array}{c}\text { 3. Project No. } \\
\text { W-441-C1 }\end{array}$ & 4. Page \\
\hline
\end{tabular}

5. Document Number(s)/Title(s)

6. Program/Project/ Building Number

Construction Spec. for Project W-441-C1, Cold Vacuum Drying Facility

17. Comment Submittal Approval:

10. Agreement with indicated comment disposition(s)

Organization Manager (Optional)

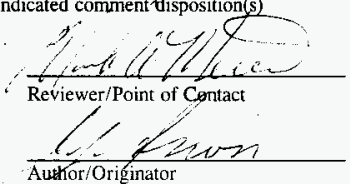

8. Organization/Group

9. Location/Phone

$2 \mathrm{~A} 310$

$1718 \mathrm{~K} / 373-3345$

11. CLOSED

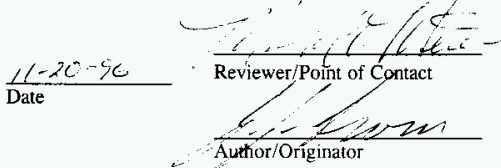

\begin{tabular}{l|l|l|l}
\hline 12. & 13. Comment(s)/Discrepancy(s) (Provide technical justification for the comment and & 14
\end{tabular} detailed recommendation of the action required to correct/ resolve the discrepancy/problem Hold Item indicated.)

1 There is no construction specification for the Demin/DI unit.

2 Line and drawing numbers do not match from H-1-82164 for Demin water, Inst. N2, waste water, cool water supply and return lines to the listed H-1 drawings.

3 Construction Specification 15456 only specifies the low level waste tank and the condensate tank. What about all the other tanks listed on the drawings such as the chilled water tanks and the 300 gallon receiver tank.

4 Drawing H-1-82221 in the note section references drawing H-1-826760 for a P\&ID legend. I am not aware of any of the $\mathrm{H}-1$ Numbers going that high and I do not see it in on the drawing list and vicinity map H-1-82090.

$\circ$ if 5 H-1-82221 is missing CS in the legend. 6 H-1-82164 lists H-1-822XX incomplete drawing numbers.

7 H-1-82163 line and drawing numbers do not match up for the liquid waste (LW103-SS-1).

8 H-1-82161 shows line segment for HE is a $\mathrm{l}^{\prime \prime}$. When going to the reference drawing H-1-82226 it only depicts $3 / 4 "$ and $1 / 2 "$.

15. Disposition (Provide justification if NOT accepted.) GFE, see P\&ID H-1-82222.

The RLW system was a late entry and as such was not attended full integration into the facility package. Will be fixed.

Correct. Added "Waste" to title to clarify. Other tanks are specifted in schedules of corresponding sections.

300 gallon tank not yet fully specified while waiting on criticality review, and not part of facility procurement.

\section{Corrected}

Added.

Will be corrected.

Will be corrected.

Disconnect will be corrected.

\section{ce}

